\title{
Environmental Evaluation of New Generation Vehicles and Vehicle Components
}

\section{December 2001}

Prepared by

Susan M. Schexnayder ${ }^{1}$

Sujit Das ${ }^{2}$

Rajive Dhingra ${ }^{1}$

Jonathan G. Overly ${ }^{1}$

Bruce E. Tonn ${ }^{2}$

Jean H. Peretz ${ }^{1}$

Greg Waidley ${ }^{1}$

Gary A. Davis ${ }^{1}$

${ }^{1}$ University of Tennessee-Knoxville

${ }^{2}$ Oak Ridge National Laboratory 


\section{DOCUMENT AVAILABILITY}

Reports produced after January 1, 1996, are generally available free via the U.S. Department of Energy (DOE) Information Bridge:

Web site: http://www.osti.gov/bridge

Reports produced before January 1, 1996, may be purchased by members of the public from the following source:

National Technical Information Service

5285 Port Royal Road

Springfield, VA 22161

Telephone: 703-605-6000 (1-800-553-6847)

TDD: 703-487-4639

Fax: 703-605-6900

E-mail: info@ntis.fedworld.gov

Web site: http://www.ntis.gov/support/ordernowabout.htm

Reports are available to DOE employees, DOE contractors, Energy Technology Data Exchange (ETDE) representatives, and International Nuclear Information System (INIS) representatives from the following source:

Office of Scientific and Technical Information

P.O. Box 62

Oak Ridge, TN 37831

Telephone: 865-576-8401

Fax: 865-576-5728

E-mail: reports@adonis.osti.gov

Web site: http://www.osti.gov/contact.html

This report was prepared as an account of work sponsored by an agency of the United States Government. Neither the United States government nor any agency thereof, nor any of their employees, makes any warranty, express or implied, or assumes any legal liability or responsibility for the accuracy, completeness, or usefulness of any information, apparatus, product, or process disclosed, or represents that its use would not infringe privately owned rights. Reference herein to any specific commercial product, process, or service by trade name, trademark, manufacturer, or otherwise, does not necessarily constitute or imply its endorsement, recommendation, or favoring by the United States Government or any agency thereof. The views and opinions of authors expressed herein do not necessarily state or reflect those of the United States Government or any agency thereof. 
ORNL/TM-2001-266

Engineering Science and Technology Division

\title{
ENVIRONMENTAL EVALUATION OF NEW GENERATION VEHICLES AND VEHICLE COMPONENTS
}

December 2001

\author{
Susan M. Schexnayder ${ }^{1}$ \\ Sujit Das ${ }^{2}$ \\ Rajive Dhingra $^{1}$ \\ Jonathan G. Overly ${ }^{1}$ \\ Bruce E. Tonn ${ }^{2}$ \\ Jean H. Peretz ${ }^{1}$ \\ Greg Waidley ${ }^{1}$ \\ Gary A. Davis ${ }^{1}$ \\ ${ }^{1}$ University of Tennessee-Knoxville \\ ${ }^{2}$ Oak Ridge National Laboratory
}

\author{
Prepared for \\ Office of Advanced Automotive Technologies \\ Office of Transportation Technologies \\ U.S. Department of Energy \\ Washington, D.C. \\ Prepared by \\ OAK RIDGE NATIONAL LABORATORY \\ Oak Ridge, Tennessee 37831-6285 \\ managed by \\ UT-BATTELLE, LLC \\ for the \\ U.S. Department of Energy \\ under contract DE-AC05-00OR22725
}





\section{CONTENTS}

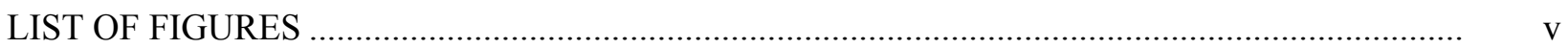

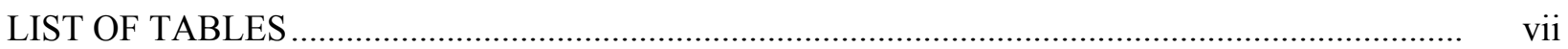

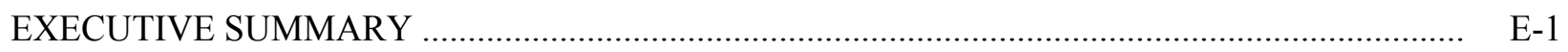

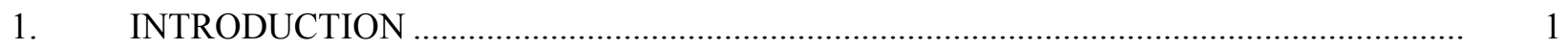

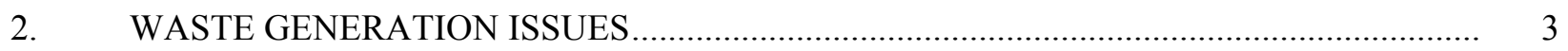

$2.1 \quad$ ASSESSMENT OF E\&MP WASTE STREAM ..................................................... 4

2.1.1 Methodology and Assumptions .............................................................. 5

2.1.2 E\&MP Wastes from 3XVs ....................................................................... 6

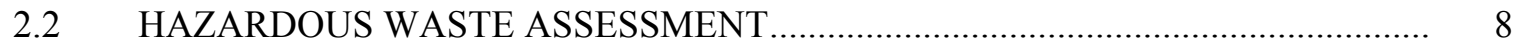

2.2.1 Methods, Assumptions, and Qualifiers ......................................................... 8

2.2.2 Hazardous Wastes from Select 3XV Materials .............................................. 9

2.3 AUTOMOBILE SHREDDER RESIDUE AND HAZARDOUS WASTE

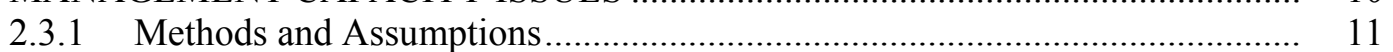

2.3.2 Overview of the Federal Waste Management Regulatory Framework............ 12

2.3.3 Current Recycling Practices........................................................................... 13

2.3.4 Automotive Shredder Residue (ASR) Composition ...................................... 14

2.3.5 New Vehicle Material and ASR Balance................................................. 15

2.3.6 Municipal Solid Waste Management Capacity ................................................. 17

2.3.7 Hazardous Waste Management Capacity Requirements .............................. 17

2.3.7.1 Relating Different Waste Categorization Schemes........................... 17

2.3.7.2 Hazardous Waste Management Capacity ......................................... 19

2.4 SPATIAL ASSESSMENT OF 3XVs' EXTRACTION AND MATERIAL

2.5 WASTE ASSESSMENT CONCLUSIONS AND RECOMMENDATIONS ............. 22

2.0 LIFE-CYCLE ASSESSMENTS ............................................................................. 25

$3.1 \quad$ INTRODUCTION TO THE LIFE-CYCLE ASSESSMENTS ……......................... 25

3.1.1 The Life-Cycle Approach .................................................................. 25

3.1.2 Life-Cycle Stages..................................................................... 25

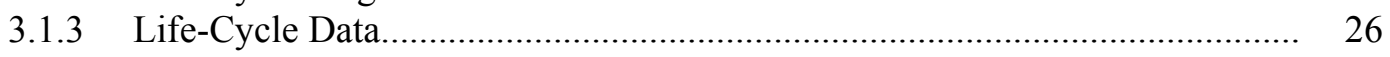

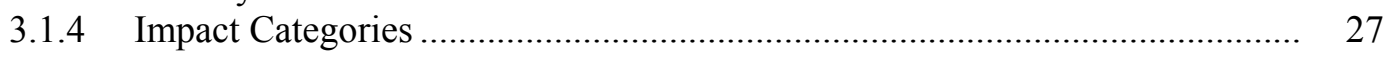

3.2 METHODOLOGY AND OVERALL ASSUMPTIONS ...................................... 29

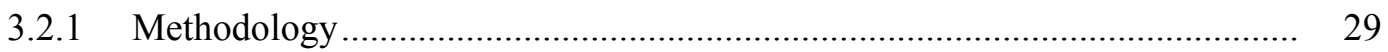

3.2.2 Overall Assumptions.......................................................................... 30

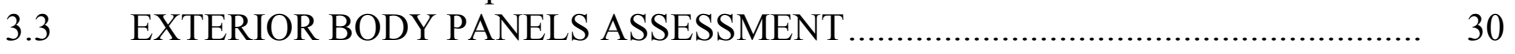

3.3.1 Background and Scope ......................................................................... 30

3.3.2 Assessment-Specific Assumptions ……................................................. 31

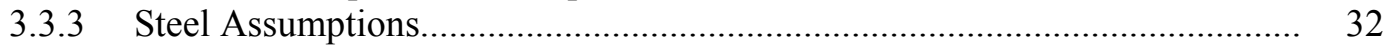

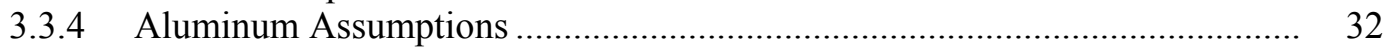




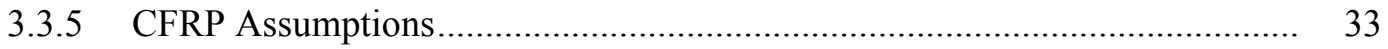

3.3.6 GFRP Assumptions............................................................................. 33

3.3.7 Monocoque (LT) Analysis Assumptions ………………………………….... 33

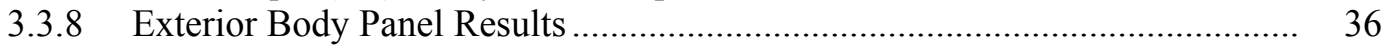

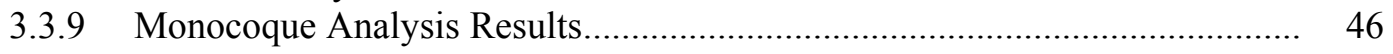

3.4 HYBRID ELECTRIC VEHICLE BATTERY ASSESSMENT .................................. 48

3.4.1 Background and Scope .......................................................................... 48

3.4.2 Assessment-Specific Assumptions ............................................................. 48

3.4.3 Lilon Assumptions .............................................................................. $\quad 50$

3.4.4 NIMH Assumptions ............................................................................... 53

3.4.5 Long-Term Scenario ................................................................................. 53

3.4.6 NiMH and Lilon Battery Results ............................................................... 57

$3.5 \quad$ FUEL CELL VEHICLE ASSESSMENT ………………………………………. 67

3.5.1 Background and Scope ………………………………………………...... 67

3.5.2 Assessment-Specific Assumptions ............................................................. 68

3.5.3 1994 Baseline Vehicle ................................................................................ 69

3.5.4 Direct Hydrogen Fuel Cell Vehicle ……………………………………..... 69

3.5.5 Methanol-and Gasoline-fueled Fuel Cell Vehicles........................................ 69

3.5.6 Long-Term Scenario ................................................................................. $\quad 72$

3.5.7 Fuel Cell Vehicle Results ........................................................................... 74

3.6 LCA CONCLUSIONS AND RECOMMENDATIONS ............................................ 86

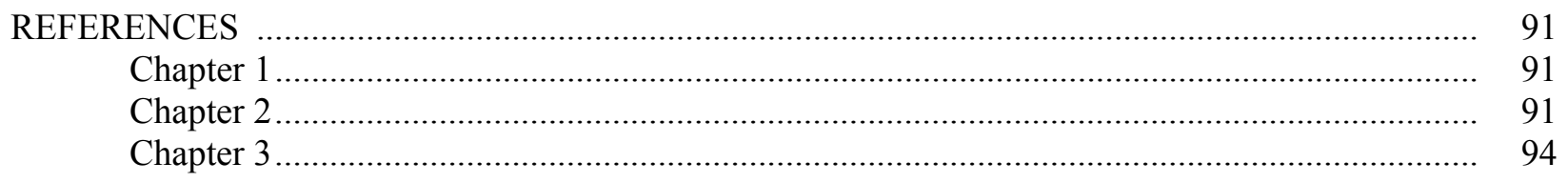

APPENDIX A REFERENCES RELATING TO THE CONSTITUENTS OF ASR …………............. 99

Part 1: References that identify ASR Constituent by Percentage Weight................................... 99

Part 2: References for ASR Without Composition by Weight/Percentages .............................. 99

APPENDIX B GLOSSARY OF ACRONYMS AND TECHNICAL TERMS USED IN THE LCA.... 101

APPENDIX C IMPACT CATEGORY DEFINITIONS...………………………………............ 105

APPENDIX D A CLOSER LOOK AT THE DATA-PARTICULARS AND ENERGY

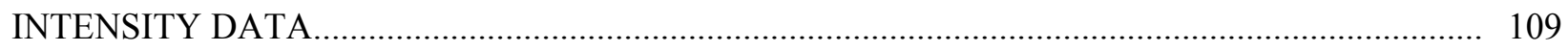

APPENDIX E SNAPSHOTS OF THE LCD TOOLKIT …………………………………............. 113 


\section{LIST OF FIGURES}

2.1 LCI Inputs and Outputs to a Unit Process .................................................................. 26

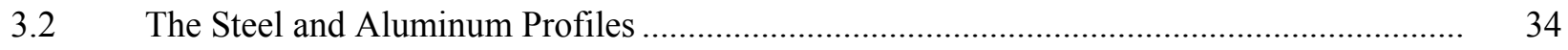

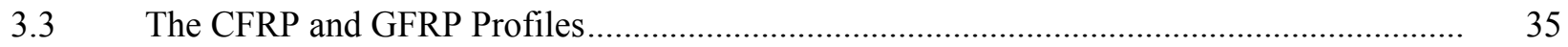

3.4 Exterior Body Panels - Steel vs. Aluminum Comparison ...................................................

3.5 Exterior Body Panels - Steel vs. CFRP Comparison ...................................................... 38

3.6 Exterior Body Panles - Steel vs. GFRP Comparison ................................................... 39

3.7 Exterior Body Panels - CFRP vs. Aluminum Comparison ............................................. 39

3.8 Exterior Body Panels - CFRP vs. GFRP Comparison ................................................ 40

3.9 Exterior Body Panels - Nonrenewable Resource Use ......................................................

3.10 Exterior Body Panels - Energy Use ….................................................................... 42

Exterior Body Panels - Global Warming Potential......................................................

Exterior Body Panels - Solid Waste Landfill Space ...................................................

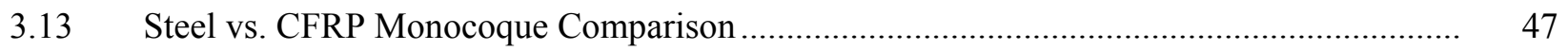

3.14 The Lilon HEV Battery Profile ............................................................................... 52

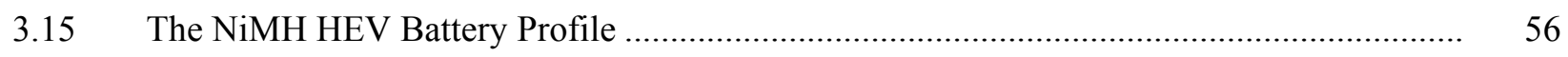

3.16 HEV Batteries - Lilon vs. NiMH Comparison .......................................................... 59

3.17 HEV Batteries - Lilon LT vs. NiMH-LT Comparison .............................................. 59

3.18 HEV Batteries - Lilon vs. Lilon-LT Comparison ....................................................... 60

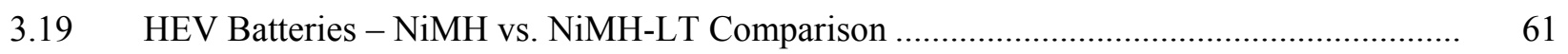

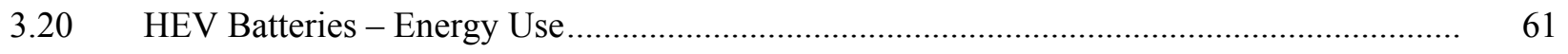

3.21 HEV Batteries - Global Warming Potential .............................................................. 62

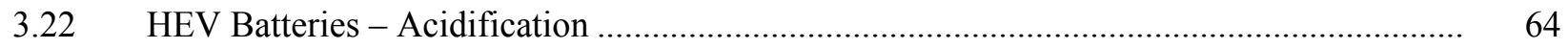

3.23 HEV Batteries - Solid Waste Landfill Space................................................................. 66 
$3.24 \quad$ The ICEV Propulsion System Profile ....................................................................

3.25 A Representation of the Multiple FCV Profiles ........................................................... 71

3.26 FCVs - ICEV vs. H2FCV Comparison..................................................................

3.27 FCVs - ICEV vs. RFCV - gas Comparison ............................................................ 77

3.28 FCVs - ICEV vs. RFCV - gas - LT Comparison ......................................................... 77

3.29 FCVs - ICEV vs. RFCV - MeOH Comparison ……....................................................

3.30 FCVs - ICEV - RFCV Comparison - Gas vs. MeOH......................................................

3.31 FCVs - Gas Comparison - gas vs. gas-LT …...............................................................

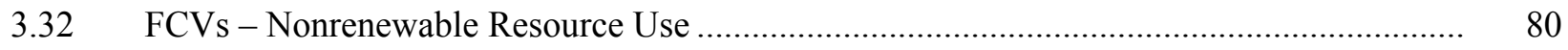

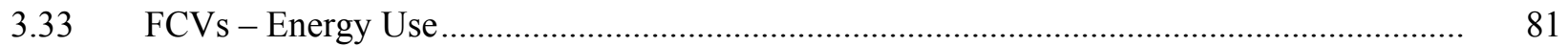

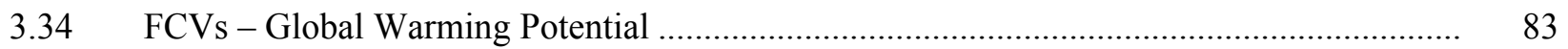

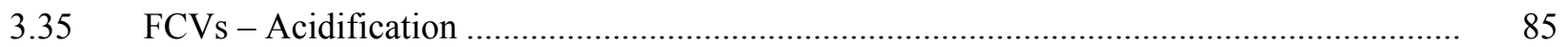

E.1 The LCD Toolkit's Profile Builder - Manages the Building of Profiles from Processes ...... 113

E.2 The LCD Toolkit's Process Builder - Manages the Building of Processes from Individual Inputs and Outputs ............................................................................... 114

E.3 The LCD Toolkit's Input/Output Databases - Manages all the Inputs and Outputs used to build Processes 


\section{LIST OF TABLES}

Foci of Waste Production Assessments........................................................................ 3

2.2 Material Composition of the 3XVs and Baseline Vehicle (lbs) ....................................... 4

2.3 $3 \mathrm{XV}$ and Baseline Vehicle Extraction and Material Processing Wastes

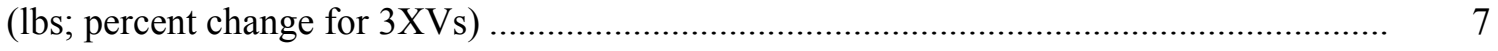

2.4 Hazardous Waste Amounts Associated with the Plastics in Each Vehicle Type.................. 7

2.5 Changes in Hazardous Waste Releases from Processing of Select Materials; 3XVs Compared to the 1994 Baseline Vehicle ..................................................................... 10

2.6 ASR Components as Reported by Two Sources (\% by weight) …................................. 15

2.7 Material Composition of the 1994 Baseline Vehicle and 3XVs, Representing Potential ASR Components (lbs.) ......................................................... 16

2.8 ASR Per Car at the End-of-Life Phase (lbs.)..................................................................... 16

2.9 Comparison of European and U.S. Waste Categories .................................................... 17

2.10 Select U.S. States Will Experience Changes in Environmental Impacts

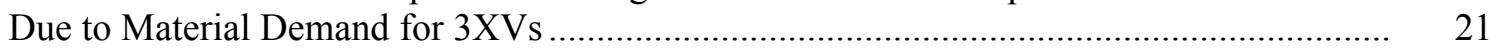

2.11 Countries Where Environmental Impacts of Extraction and Material Processing for 3 XVs Are Likely ................................................................................ 21

3.1 Profiles Evaluated for the Exterior Body Panels Assessment ........................................... 36

3.2 Impact Scores for the Exterior Body Panels Assessment............................................... 37

3.3 Nonrenewable Resources Use in the Exterior Body Panels Assessment: Life-cycle Stage Scores and Biggest Contributors

3.4 Energy Use in the Exterior Body Panels Assessment: Life-cycle Stage

Scores and Biggest Contributors

3.5 Global Warming Potential in the Exterior Body Panels Assessment:

Life-cycle Stage Scores and Biggest Contributors.

3.6 Solid Waste Landfill Space in the Exterior Body Panels Assessment:

Life-cycle Stage Scores and Biggest Contributors

3.7 Profiles Evaluated for the Monocoque Analysis .......................................................... 46

3.8 Impact Scores for the Monocoque Analysis................................................................. 
3.9 Materials breakdown for the Lilon and Lilon-LT HEV Batteries

3.10 Materials Breakdown for the NiMH HEV Battery ....................................................... 54

3.11 Materials Breakdown for the NiMH-LT HEV Battery ….............................................. 55

3.12 Profiles Evaluated for the HEV Battery Assessment .................................................. 57

3.13 Impact Scores for the HEV Battery Assessment ....................................................... 58

3.14 Energy Use in the HEV Battery Assessment: Life-cycle

Stage Scores and Biggest Contributors

3.15 Global Warming Potential in the HEV Battery Assessment: Life-cycle

Stage Scores and Biggest Contributors

3.16 Acidification in the HEV Battery Assessment: Life-cycle Stage Scores and Biggest Contributors

3.17 Solid Waste Landfill Space in the HEV Battery Assessment: Life-cycle Stage Scores and Biggest Contributors

3.18 Materials Breakdown for the Fuel Cell Vehicle Assessment ...............................................

3.19 Profiles Evaluated for the Fuel Cell Vehicle Assessment ................................................... 74

3.20 Impact Scores for the Fuel Cell Vehicle Assessment.................................................... 75

3.21 Nonrenewable Resource Use in the Fuel Cell Vehicle Assessment: Life-cycle Stage Scores and Biggest Contributors

3.22 Energy Use in the Fuel Cell Vehicle Assessment: Life-cycle Stage

Scores and Biggest Contributors

3.23 Global Warming Potential in the Fuel Cell Vehicle Assessment: Life-cycle

Stage Scores and Biggest Contributors

3.24 Comparison of GWP Scores from Different Data Sources

3.25 Acidification in the Fuel Cell Vehicle Assessment: Life-cycle

Stage Scores and Biggest Contributors

D.1 Information on the Data Used in the Assessments

D.2 Energy Intensity Data. 


\section{ENVIRONMENTAL EVALUATION OF NEW GENERATION VEHICLES AND VEHICLE COMPONENTS}

\section{EXECUTIVE SUMMARY}

\section{E.1 Introduction}

This report documents assessments that address waste issues and life cycle impacts associated with the vehicle materials and vehicle technologies being developed under the Partnership for a New Generation of Vehicles (PNGV) program. We refer to these vehicles as $3 \mathrm{XVs}$, referring to the PNGV goal that their fuel mileage be three times better than the baseline vehicle. To meet the program's fuel consumption goals, these vehicles substitute lightweight materials for heavier materials such as steel and iron that currently dominate the composition of vehicles, and use engineering and power system changes. Alternative power systems being developed through the PNGV program include batteries for hybrid electric vehicles and fuel cells. With respect to all these developments, it is imperative to learn what effects they will have on the environment before adopting these designs and technologies on a large-scale basis.

\section{E.2 Waste Generation Assessments}

In support of PNGV goals, Oak Ridge National Laboratory has conducted waste assessments addressing all wastes generated during materials extraction and processing, hazardous wastes generated during materials processing, changes in the volume of ASR - what remains for disposal after vehicles are processed for reuse and recycling - and the nation's capacity to handle it, and, from an environmental justice point of view, the locations where extraction and materials processing wastes will be generated.

\section{E.2.1 Solid Waste Assessment}

Using data from the Association of Plastic Manufacturers in Europe and a lifecycle inventory database developed by the Ecobilan Group, this assessment estimates the quantity of waste generated during the extraction and materials processing stage of the 1994 baseline vehicle and three prototype PNGV vehicles - the P2000 by Ford, the ESX2 by DiamlerChrysler, and the Precept by GM. The assessment estimates generation of five different categories of waste - mineral waste, mixed 
industrial waste, slags and ash, inert chemical waste, and hazardous waste.

The assessment finds that each of the $3 \mathrm{XVs}$ would generate more waste than the baseline vehicle- $60 \%, 62 \%$, and $82 \%$ more for the P2000, ESX2, and the Precept, respectively. The estimated total waste for the baseline vehicle is roughly $2500 \mathrm{lbs}$, while it is roughly 4500 lbs for the Precept. For the P2000 and the Precept, which rely heavily on aluminum, mineral waste accounts for $95 \%$ of the total waste. Hazardous waste is considered an area of special concern and is found to increase by $172 \%, 6 \%$, and $204 \%$, respectively, for the P2000, ESX2, and the Precept. Plastics and the new batteries - the nickel metal hydride in the P2000 and Precept, and the lithium ion battery in the ESX2 - contribute most of the hazardous waste.

\section{E.2.2 Hazardous Waste Assessment}

This assessment relies primarily on release data reported by U.S. manufacturers to EPA's Toxic Release Inventory (TRI) and equates these releases to "hazardous waste." We assume that future waste generation associated with material production will be the same as historical waste production, as reported in the TRI. The assessment considers a subset of materials in the 3XVs: steel, aluminum, titanium, magnesium, platinum, lithium, and nickel. It does not include plastics and resins, which the overall waste assessment finds to be the primary contributor to the $3 \mathrm{XVs}$ ' hazardous waste generation at the materials extraction and processing stage. The assessment finds the potential for significant increases of five specific TRI release types. PCBs, copper, and chlorine are three release types whose output is boosted by the production of the alternative metals. Although PCBs are no longer produced, they still exist in equipment that is used for and eventually retired from materials production facilities. Their release will decrease as and then be eliminated altogether once all older equipment is retired. Two other release types, nickel and ammonia, experience huge increases almost entirely because of the nickel production for the nickel-metal hydride battery. Materials production for the lithium ion battery will generate releases of lithium, a release type that does not occur in the baseline vehicle.

\section{E.2.3 ASR and Waste Management Assessment}

This assessment addresses two waste management issues related to 3XVs: changes in automotive shredder residue (ASR) at the vehicles' end-of-life stage, and the adequacy of U.S. hazardous waste management capacity to handle demand associated with $3 \mathrm{XVs}$. 
The assessment of ASR uses the vehicles' material composition and the known composition of ASR to estimate the mass of ASR associated with the baseline vehicle and $3 \mathrm{XV}$ prototypes. For example, it is known that automotive glass is not recycled and is a component of ASR currently. Thus, the assessment assumes that $100 \%$ of the mass of glass in the vehicles will be present in the ASR. This procedure is followed for each component of ASR: plastics and resins, rubber (other than tires), glass, glass and carbon fibers, fluids (other than oil), and "other."

The estimated quantity of ASR is presented by weight and as a percentage of the respective vehicle's total weight. ASR is estimated to be $582 \mathrm{lbs}$, or $18 \%$, of the baseline vehicle. The estimated mass of ASR for each of the $3 \mathrm{XVs}$ is higher than the baseline vehicle with the P2000, ESX2, and Precept having $455 \mathrm{lbs}(23 \%), 910 \mathrm{lbs}(40 \%)$, and $719 \mathrm{lbs}(28 \%)$, respectively. Plastics and fibers account for much of the ESX2 ASR, while the large "other" category in the material composition of the Precept accounts for much of its ASR.

The review of the U.S. waste regulations and waste capacity assessments reveals that there appears sufficient capacity in the United States to handle demand associated with projected economic growth, including, theoretically, the $3 \mathrm{XVs}$ ' increased generation of hazardous waste.

\section{E.2.4 Spatial Assessment of Materials Extraction and Processing}

Adopting an environmental justice perspective that considers the spatial (and, thus, demographic and socioeconomic) distribution of environmental effects of materials production activities, this assessment identifies U.S. states and other countries likely to experience impacts associated with the extraction and materials processing for $3 \mathrm{XVs}$. It also identifies states where environmental impacts are likely to be reduced because of reduced ore and coal extraction.

Every region in the United States could potentially experience some change in environmental impact with the adoption of lightweight metals. Five countries - Canada, China, South Africa, Australia, and Russia-are likely to experience increased impacts as their reserves of magnesium, bauxite, lithium, titanium, and platinum are tapped for use in $3 X V s$. Several developing countries with reserves of these same materials could also experience impacts.

Concern for potential environmental impacts is potentially greater for countries without the regulatory framework or enforcement capability 
to assure that human health and environmental quality are not degraded by the materials production activities.

\section{E.3 Life-cycle Assessments}

For Oak Ridge National Laboratory, the Center for Clean Products and Clean Technologies at the University of Tennessee conducted three life-cycle assessments (LCAs) of materials in new generation vehicles. The three assessments conducted were:

- A comparison of exterior body closure panels made of different lightweight materials (aluminum, carbon fiber-reinforced polymer [CFRP] and glass fiber-reinforced polymer [GFRP]), to steel closure panels weighing $220 \mathrm{lbs}$ as the baseline;

- A comparison of batteries for use in hybrid electric vehicles (HEVs), namely, lithium-ion (LiIon) and nickel-metal-hydride (NiMH); and

- A comparison of fuel cell vehicles (FCVs), both with and without an on-board reformer system, using direct hydrogen, gasoline, and methanol as fuels, to the conventional internal combustion engine vehicle (ICEV) as the baseline.

Each of these assessments also included a more forward-looking profile or scenario based on long-term PNGV and DOE targets or future technological trends. We refer to these as the "long-term assessments." For the Exterior Body Panels assessment, a monocoque body made of a carbon fiber-based polymer was assumed to replace a conventional steel body, resulting in a substantial weight reduction (more than 60\%). The long-term assessment for the HEV batteries was essentially a sensitivity analysis assuming a longer life span (equal to the PNGV target of 10 years) for both batteries, and a lighter, $40 \mathrm{~kg}$ $\mathrm{NiMH}$ battery (down from the $62.5 \mathrm{~kg}$ battery weight in the original assessment). The Fuel Cell Vehicle long-term assessment involved a drastic reduction in the platinum content of the stack (from about 180 grams to 20 grams), a $40 \%$ overall reduction in the weight of the reformer, and a reduction in the number of start-up batteries, from the original six to just one. These changes were applied to the gasoline FCV profile only, as this was considered to be the more practical option in the foreseeable future.

In these assessments, just as in any LCA, the results obtained are highly dependent on the data used and the assumptions made. The vast majority of life-cycle inventory data used in these assessments were secondary data from the DEAM database (Ecobilan 1999). Having a single secondary data source brought consistency to the results. 
Fourteen impact categories that included energy and material resource use, air and water emissions, and solid and hazardous waste generation were evaluated in each environmental profile.

\section{E.3.1 Exterior Body Panels Assessment}

In the life-cycle assessment comparing closure panels made of steel and other materials, carbon fiber-reinforced polymer (CFRP) appears to be the least environmentally burdensome material in 9 of the 14 impact categories evaluated, which include nonrenewable and renewable resource use, energy use, global warming, acidification, odor/aesthetics, and water quality (BOD). This is mainly because CFRP has the maximum weight reduction potential of all the materials evaluated (about $60 \%$ over steel), resulting in a much smaller quantity of material needed. Of the remaining five categories, aluminum is environmentally preferable in smog formation, eutrophication, and water quality (TSS), while GFRP has the lowest score for ozone depletion and particulate matter generation. Aluminum's environmental standing is hampered by the high energy required and large quantity of wastes generated during production of virgin aluminum (a mix of $89 \%$ virgin and $11 \%$ recycled aluminum was used for the aluminum profile). Steel does not have the lowest impact scores in any of the categories examined; however, it is expected that UltraLight steel could better compete with the other lightweight materials.

In the monocoque analysis performed as part of the long-term assessment, CFRP's position is further strengthened (compared to the original assessment). However, its impact scores in three categories turn around from being lower than those of steel to being higher than steel. The major contributors in each case are various releases associated with using larger amounts of carbon fiber.

\section{E.3.2 Hybrid Electric Vehicle Battery Assessment}

In this assessment, a $40 \mathrm{~kg}$ LiIon battery was compared to a $62.5 \mathrm{~kg}$ $\mathrm{NiMH}$ battery. Though lighter in weight, the LiIon possesses more specific power, thus delivering approximately the same amount of power as the NiMH battery. Based on PNGV data, these "current performance" HEV batteries were assumed to have a life span of three years and five years, respectively. In spite of the fact that 3.33 LiIon batteries are used over the life of the vehicle in the profile, versus 2 $\mathrm{NiMH}$ batteries in the NiMH profile, the assessment revealed that LiIon has lower impacts in almost all the impact categories evaluated (12 out of 14). The nickel contained in the NiMH battery is a big 
contributor to the high impact scores in a number of categories. Nickel production is highly energy intensive and also generates considerable quantities of sulfur dioxide, resulting in an increased acidification potential. Solid waste and particulate generation are the only two categories in which NiMH scores better than LiIon. The solid waste impact score is higher for the LiIon battery mainly due to the large quantities of solid wastes generated in the production of aluminum, which is used in the battery and cell containers, and in the current collector.

The long-term assessment considered a lighter NiMH battery and battery life of 10 years, but the results were unaffected. LiIon maintains its edge over $\mathrm{NiMH}$, in the same impact categories as in the original assessment.

\section{E.3.3 Fuel Cell Vehicle Assessment}

In this comparison of a conventional ICEV with a direct-hydrogen fuel cell vehicle, a reformed gasoline FCV, and a reformed methanol FCV, the hydrogen FCV is found to have the lowest impact scores in 12 of the 14 impact categories evaluated, mainly because of zero air emissions from driving and the lowest total lifetime quantity by mass of fuel (hydrogen) required during use. In 5 of these 12 categories, the gasoline FCV is a close second.

Between the two FCVs with reformers (gasoline- and methanolbased), the only differences were in the Use stage (which includes Fuel Use and Fuel Production). The higher impacts for the methanol FCV are primarily due to the larger quantity of methanol required, given that its energy content is approximately half that of gasoline. Methanol production is also a big contributor to the methanol FCV's higher impacts, including global warming and acidification. Though the methanol production data used in this assessment results in higher impact scores in certain impact categories (e.g., energy use and global warming potential) as compared to results of other studies, it was decided to use the same data source for methanol as for the other materials (i.e., DEAM), in order to maintain consistency in the assessment.

In the original assessment, the fuel cell + reformer system contributed significantly to the overall vehicle weight, with a combined mass of more than $600 \mathrm{~kg}$. The long-term profile for the gasoline FCV, on account of its reduced platinum content and reduced overall weight (reduced by $\sim 220 \mathrm{~kg}$ ), has the lowest impact scores in 3 categories (nonrenewable resource use, energy use, and smog formation), while the hydrogen FCV still leads in the other nine impact categories. Also, 
the long-term gasoline FCV's scores are now much closer to the hydrogen FCV's scores. The hydrogen FCV, however, still remains the most environmentally preferable vehicle. 



\section{INTRODUCTION}

The Partnership for a New Generation of Vehicles (PNGV) program is working to produce automobiles that will reduce fuel consumption by two-thirds while maintaining price, comfort, safety and performance comparable to current mid-size vehicles. Under this program, the "Big 3" U.S. automakers-Ford, DaimlerChrysler, and GM-have developed prototype vehicles, the P2000, the ESX2 and subsequent models, and the Precept, respectively. To achieve the fuel consumption goals, these vehicles substitute lightweight materials for heavier materials such as steel and iron that currently dominate the composition of automobile components, and use engineering and powertrain system changes. Alternative power systems being developed through the PNGV program include batteries for hybrid electric vehicles and fuel cells. With respect to all these developments, it is imperative to learn what effects they will have on the environment and on material supply before adopting these designs and technologies on a large-scale basis.

Prior to the work reported here, Oak Ridge National Laboratory had conducted life-cycle analyses of the P2000 and the ESX2, two of the three 3XV prototypes, as well as the baseline vehicle. ORNL also had examined infrastructure and acceptability issues, including an assessment of materials availability issues that focused on major substitute materials. Other issues addressed in previous work include the effect of new vehicle types on the existing automotive recycling and vehicle use and repair infrastructures, and consumer acceptability of the new vehicles. (Das et al. 1997, 1999, 2000).

This report documents assessments that address life cycle impact and waste issues associated with the large-scale adoption of these technologies and vehicles. We refer to these vehicles as $3 \mathrm{X}$ vehicles - or $3 \mathrm{XVs}$ - because of the PNGV goal of improving current fuel efficiency by a factor of three. The life-cycle analyses delve into the effects of various body panel material types, hybrid electric vehicle batteries, and fuel cells. The assessment of wastes addresses all wastes generated during materials extraction and processing, hazardous wastes generated during materials processing, changes in the volume of ASR and the nation's capacity to handle it, and, from an environmental justice point of view, the locations where extraction and materials processing wastes will be generated.

The report is presented in two parts. The first part, Chapter 2, reports the waste-related assessments. It includes information about the composition of the three prototype vehicles' materials requirements, which are used to underpin various aspects of the waste assessments. The last section of Chapter 2 addresses how the findings relate to each other, as well as to the life cycle assessments in Chapter 3, and identifies potential next steps in the analyses. The second part of the report, Chapter 3, discusses the life-cycle assessments of exterior body panels constructed of various materials, hybrid electric vehicle batteries, and fuel cells. The last section of Chapter 3 discusses the implications of the findings of the life-cycle assessments and identifies potential next steps in life cycle analysis. 



\section{WASTE GENERATION ISSUES}

In this chapter we present the methods, assumptions and results of separate, but related, assessments of the wastes associated with the $3 \mathrm{XVs}$. Table 2.1 is an overview of these assessments. The first of the four assessments presented here addresses all types of solid waste produced during the extraction and processing of materials for the $3 \mathrm{XVs}$. This assessment accounts for the entire materials content of the vehicles. The second focuses on certain hazardous wastes generated during materials processing. These two assessments address materials processing wastes but do not include the wastes associated with the energy needed to power the materials processing. The third assessment addresses automobile shredder residue, while the fourth, taking the perspective of environmental justice, identifies states and countries where materials activities and their potential impacts would occur.

Table 2.1. Foci of Waste Production Assessments

\begin{tabular}{|c|c|c|c|c|}
\hline \multirow[b]{2}{*}{ Assessment } & \multicolumn{2}{|c|}{ Type of Waste } & \multirow[b]{2}{*}{ Life-cycle Stage } & \multirow{2}{*}{$\begin{array}{c}\text { Treatment of } \\
\text { "Hazardous } \\
\text { Waste" }\end{array}$} \\
\hline & $\begin{array}{c}\text { Category of } \\
\text { Waste } \\
\end{array}$ & Discharged to... & & \\
\hline $1($ Section 2.1$)$ & $\begin{array}{l}\text { Total solid and } \\
\text { hazardous waste } \\
\text { stream from the } \\
\text { totality of } \\
\text { vehicles' } \\
\text { materials }\end{array}$ & $\begin{array}{l}\text { Excludes wastes } \\
\text { discharged to } \\
\text { water }\end{array}$ & $\begin{array}{l}\text { Extraction and } \\
\text { materials } \\
\text { processing }\end{array}$ & $\begin{array}{l}\text { Aggregates all } \\
\text { hazardous wastes }\end{array}$ \\
\hline $2($ Section 2.2$)$ & $\begin{array}{l}\text { Subset of toxic } \\
\text { releases from } \\
\text { processing of } \\
\text { some materials }\end{array}$ & $\begin{array}{l}\text { Includes releases } \\
\text { to water, land, and } \\
\text { off-site transfer }\end{array}$ & $\begin{array}{l}\text { Materials } \\
\text { processing only }\end{array}$ & $\begin{array}{l}\text { Identifies the mass } \\
\text { of specific types of } \\
\text { toxic releases } \\
\text { (which can be } \\
\text { constituents of } \\
\text { hazardous waste) }\end{array}$ \\
\hline $3($ Section 2.3$)$ & $\begin{array}{l}\text { Automobile } \\
\text { shredder residue } \\
(\mathrm{ASR})\end{array}$ & Landfill & End of life & $\begin{array}{l}\text { ASR is classified } \\
\text { as a non-hazardous } \\
\text { waste }\end{array}$ \\
\hline 4 (Section 2.4) & $\begin{array}{l}\text { Addresses, } \\
\text { generally, the } \\
\text { potential for } \\
\text { waste to be } \\
\text { produced in } \\
\text { specific locales }\end{array}$ & n.a. & $\begin{array}{l}\text { Extraction and } \\
\text { materials } \\
\text { processing }\end{array}$ & n.a. \\
\hline
\end{tabular}

n.a.: not applicable 
These assessments of waste determine waste output per vehicle based on the material content of the three 3XVs - the P2000, the ESX2, and the Precept - as reported by their respective developers. Table 2.2 shows the material composition of the base vehicle (considered here to be the 1994 model year) and the three prototype vehicles considered in this study. These vehicle prototypes indicate considerable progress towards the PNGV goal of reducing vehicle mass by $40 \%$. The P2000 and Precept are both aluminum-intensive vehicles, although the P2000 uses proportionally more wrought aluminum and the Precept uses more cast aluminum. The ESX2, and DaimlerChrysler's subsequent models based on it, are composites-intensive vehicles. This vehicle materials breakdown includes the new battery types as a separate category of materials. The make-up of these batteries is derived from information obtained for and produced in the batteries assessment in Chapter 3. The battery materials for the baseline vehicles remain in the "other" category. Lexan (commonly known as "polycarbonates"), carbon fibers, and titanium are 3XV materials not used at all in the baseline vehicle.

\begin{tabular}{|c|c|c|c|c|}
\hline \multicolumn{5}{|c|}{ Table 2.2. Material Composition of the 3XVs and Baseline Vehicle (lbs) } \\
\hline & Baseline & P2000* & ESX2* & Precept \\
\hline Wrought Al & 47 & 462 & 330 & 304 \\
\hline Cast Al & 159 & 271 & 120 & 820 \\
\hline Magnesium & 6 & 86 & 122 & 7 \\
\hline Titanium & 0 & 11 & 40 & 33 \\
\hline Platinum & 0.0033 & 0.01 & 0.01 & 0.01 \\
\hline Ferrous & 2168 & 490 & 528 & 487 \\
\hline Plastics & 193 & 209 & 52 & 187 \\
\hline Resins (for composites) & 28 & 40 & 428 & 86 \\
\hline Carbon fiber & 0 & 8 & 24 & 22 \\
\hline Glass fiber & 19 & 19 & 60 & 35 \\
\hline Lexan & 0 & 30 & 20 & 0 \\
\hline Glass & 97 & 36 & 70 & 57 \\
\hline Rubber & 139 & 123 & 148 & 77 \\
\hline NiMH or LiIon batteries & 0 & 138 & 88 & 138 \\
\hline Other & 391 & 83 & 212 & 338 \\
\hline Total & 3248 & 2010 & 2250 & 2591 \\
\hline
\end{tabular}

* Includes updated information available on the latest versions of Prodigy and ESX3.

\subsection{ASSESSMENT OF THE E\&MP WASTE STREAM}

The purpose of this assessment was to characterize the total waste stream produced in the extraction and material processing (E\&MP) lifecycle stage for each of the three $3 \mathrm{XVs}$ considered here. This study estimates the total waste stream and categorizes it by type of waste. It builds upon previous lifecycle analysis work (Das et al. 2000) that showed that more than $75 \%$ of the $3 \mathrm{XVs}$ ' lifetime solid waste generation occurred in the E\&MP stage. This previous work did not characterize the waste stream by type of solid waste. Additionally, the assessment reported here includes three of the $3 \mathrm{XV}$ prototype vehicles and examines the contribution of alternative batteries to the total waste stream. 


\subsubsection{Methodology and Assumptions}

This assessment uses the material composition of the three $3 \mathrm{XVs}$ and a baseline vehicle (see Table 2.2), along with industry-reported E\&MP waste streams to determine the wastes produced in the extraction and materials processing lifecycle stage for each vehicle type. Industry-reported waste streams (units of waste per unit of material produced) are multiplied by the amount of material in the vehicle to determine each material's contribution to the vehicle's waste stream. The waste streams of each material in the vehicle are added to determine total waste for each vehicle type.

The materials breakdown includes the predominant materials in the vehicles and other, smaller 3XV inputs that are considerably different from the baseline vehicle, e.g., lexan and platinum. Materials that occur in small quantities are reported in a category labeled "other."

The assessment assumes that nickel-metal hydride (NiMH) batteries power the P2000 and the Precept, while the ESX2 employs a lithium ion (LiIon) battery. The mass of the $3 \mathrm{XVs}$ ' batteries has been subtracted from the "other" materials category. The material composition includes a single battery for each car, as opposed to lifetime battery requirements ( $2 \mathrm{NiMH}$ and 3.3 LiIon batteries). The batteries' material composition (and waste output) was determined for the battery-specific lifecycle assessment (see Chapter 3) and included in this waste assessment. Therefore, new battery types appear as a "material" in the material composition list.

Most data sources used in this assessment have wastes designated as one of the five categories. The five categories of waste are mineral waste, mixed industrial waste, slags and ash, inert chemical waste, and regulated hazardous waste. Each is defined here.

- Mineral waste is the waste earth and rock generated in mining operations.

- Slags and ash refer to the solid waste produced by industrial boilers and furnaces.

- Inert chemical waste is chemical waste that could be sent to landfill sites without treatment.

- Regulated hazardous waste, because of its toxicity, must be sent to special storage sites.

- Mixed industrial waste is the general waste that does not fit into one of the other categories and in the U.S. is allowed in Subtitle D (i.e., non-hazardous waste) landfills (Boustead 1997).

The primary data sources were the Association of Plastic Manufacturers in Europe (APME 2000; Boustead 1997), the DEAM lifecycle inventory database (Ecobilan 1999), and proprietary data. The proprietary data collected directly from companies are one of only a few exceptions to this "pre-designation" of wastes into the five categories. In cases where wastes had to be assigned to a category, the analyst relied on the definitions of the waste categories and examples in the data of types of waste assigned to specific categories.

Most of the data is from European sources and includes the category "regulated chemical waste." For the purposes of this analysis we have assumed that European "regulated chemical 
waste" is roughly the equivalent of "regulated hazardous waste" as defined in the U.S. Resource Conservation and Recovery Act.

This assessment includes only "solid" wastes attributable to materials extraction and processing. It excludes the waste resulting from producing the energy required by the material processing, and excludes air emissions and discharges to water.

The analysis assumes that many of the materials will be derived from a mix of virgin and secondary sources. Assumed recycled contents are 11\% for wrought aluminum, $65 \%$ for cast aluminum, $40 \%$ for ferrous material, and $40 \%$ for magnesium. All other materials are assumed to be virgin materials. Data for carbon fiber includes solid waste associated with the raw material, the fiber precursor, and the carbon fiber itself. The resins with which the carbon and glass fibers will be mixed are included as a separate category. Based on current prototypes, we assume that the glass fiber of the ESX2 is formed with polyethylene terephthalate (PET), and the glass fiber for the other vehicles and the carbon fibers for all vehicles are formed with liquid epoxy resin.

For two material input categories, i.e., plastics and "other," waste streams (pounds of waste produced per pound of material produced) had to be constructed. The constructed "plastics" waste stream includes the wastes from various automotive plastics at the ratio they occur in the baseline car. The "other" category was constructed by averaging all waste streams of the materials used in the vehicles. ${ }^{\text {a }}$

\subsubsection{E\&MP Wastes from $3 X V s$}

Table 2.3 presents the results of this waste assessment, showing the mass of each of the five types of waste. In the mineral, mixed industrial, slags, and inert chemical categories and in the total waste, the waste includes the waste from the 3XVs' new batteries. In the regulated hazardous waste category, two figures are presented - one including the new batteries, one excluding them - to show the contribution the batteries make to this waste category.

Like a previous assessment (Das et al. 2000), this assessment shows that the total waste stream of each of the $3 \mathrm{XVs}$ is greater than that of the baseline vehicle. Total waste increases range from $60 \%$ to $82 \%$. For the baseline vehicle and the ESX2, mineral waste accounts for $80 \%$ of the total E\&MP waste. For the P2000 and Precept, which rely heavily on aluminum, a big contributor of mineral waste, it accounts for $95 \%$ of the total waste.

In the next three waste categories - mixed industrial, slags and ash, and inert chemicalschanges in the amount of waste produced vary widely. For example, the slags and ash produced by the P2000 and the Precept are more than 50\% less than the baseline vehicle, but in the ESX2 this waste increases by nearly 100\%. The P2000 and the Precept have changes that are in the same direction and similar in size, largely because of their similar material composition. "Slags and ash" is largely, but not exclusively, associated with power

\footnotetext{
${ }^{a}$ Platinum was excluded because it was considered a relatively unique material type and because platinum data exclude extraction wastes.
} 
Table 2.3. 3XV and Baseline Vehicle Extraction and Material Processing Wastes (lbs; percent change for $3 \mathrm{XVs}$ )

\begin{tabular}{|c|c|c|c|c|c|c|c|}
\hline \multirow[b]{2}{*}{ Vehicle } & \multirow[b]{2}{*}{$\begin{array}{l}\text { Mineral } \\
\text { waste }\end{array}$} & \multirow[b]{2}{*}{$\begin{array}{c}\text { Mixed } \\
\text { industrial } \\
\text { waste }\end{array}$} & \multirow[b]{2}{*}{$\begin{array}{l}\text { Slags and } \\
\text { ash }\end{array}$} & \multirow[b]{2}{*}{$\begin{array}{c}\text { Inert } \\
\text { chemical } \\
\text { waste }\end{array}$} & \multicolumn{2}{|c|}{$\begin{array}{c}\text { Regulated hazardous } \\
\text { waste }\end{array}$} & \multirow[b]{2}{*}{ Totals } \\
\hline & & & & & $\begin{array}{c}\text { With } \\
\text { new } \\
\text { batteries }\end{array}$ & $\begin{array}{c}\text { Without } \\
\text { new } \\
\text { batteries }\end{array}$ & \\
\hline Baseline & 2109.53 & 53.11 & 315.48 & 2.07 & na & 3.78 & 2483.97 \\
\hline P2000 & $\begin{array}{r}3749.42 \\
(78 \%)\end{array}$ & $\begin{array}{r}65.39 \\
(23 \%) \\
\end{array}$ & $\begin{array}{l}137.90 \\
(-56 \%) \\
\end{array}$ & $\begin{array}{r}6.26 \\
(202 \%) \\
\end{array}$ & $\begin{array}{r}10.28 \\
(172 \%) \\
\end{array}$ & $\begin{array}{l}4.11 \\
(9 \%)\end{array}$ & $\begin{array}{r}3969.25 \\
(60 \%) \\
\end{array}$ \\
\hline ESX2 & $\begin{array}{r}3213.71 \\
(52 \%)\end{array}$ & $\begin{array}{r}171.77 \\
(223 \%)\end{array}$ & $\begin{array}{r}623.93 \\
(98 \%) \\
\end{array}$ & $\begin{array}{l}3.11 \\
(6 \%)\end{array}$ & $\begin{array}{r}4.01 \\
(6 \%) \\
\end{array}$ & $\begin{array}{r}2.67 \\
(-29 \%) \\
\end{array}$ & $\begin{array}{r}4016.50 \\
(62 \%)\end{array}$ \\
\hline Precept & $\begin{array}{l}4273.67 \\
(102 \%)\end{array}$ & $\begin{array}{r}81.27 \\
(53 \%)\end{array}$ & $\begin{array}{l}143.73 \\
(-54 \%)\end{array}$ & $\begin{array}{r}7.64 \\
(269 \%)\end{array}$ & $\begin{array}{r}11.51 \\
(204 \%)\end{array}$ & $\begin{array}{r}5.34 \\
(41 \%)\end{array}$ & $\begin{array}{r}4517.82 \\
(82 \%)\end{array}$ \\
\hline
\end{tabular}

production (especially fossil-fuel electricity generation); including the energy input needed for materials production would greatly increase the wastes in this category.

Perhaps the most significant changes - because of the magnitude of the change and the type of waste- occur in the regulated hazardous waste category. Here the analysis addresses the waste that would be produced given current battery technology, as well as those that would occur given the adoption of nickel metal hydride (NiMH) or lithium ion (LiIon) batteries. Without the new batteries, the regulated hazardous waste increases slightly in the P2000 (9\%), moderately in the Precept (41\%), and hazardous waste declines in the ESX2. Plastics, in general, are the largest contributor of regulated hazardous waste. Although the ESX2 relies heavily on composites that mix fiber and a plastic resin together, the resin used for forming the glass fibers in the ESX2 is PET, a relatively benign plastic, according to the APME data source (APME 2000). This keeps the regulated hazardous waste stream of the ESX2 smaller than that of the P2000 and Precept. The relative contribution of plastics to the vehicles' regulated hazardous waste stream is shown in Table 2.4. In the table, plastics include the general category "plastics," as well as resins for composites, and lexan.

\begin{tabular}{|l|c|c|}
\hline \multicolumn{3}{|c|}{$\begin{array}{c}\text { Table 2.4. Hazardous Waste Amounts Associated } \\
\text { with the Plastics in Each Vehicle Type }\end{array}$} \\
\hline \hline Vehicle & $\begin{array}{c}\text { "Plastics" (lbs) in } \\
\text { each vehicle }\end{array}$ & $\begin{array}{c}\text { Regulated Hazardous } \\
\text { Wastes (lbs) from } \\
\text { Plastics }\end{array}$ \\
\hline Baseline & 220.72 & 2.68 \\
\hline P2000 & 278.60 & 3.37 \\
\hline ESX2 & 500.15 & 1.51 \\
\hline Precept & 273.37 & 3.71 \\
\hline
\end{tabular}


When the new battery types are factored into the vehicles' materials, hazardous waste increases. The NiMH battery in the P2000 and the Precept increases the regulated hazardous waste $172 \%$ and $204 \%$, respectively, above the baseline vehicle's level of regulated hazardous waste. The LiIon battery causes the ESX2's regulated hazardous waste to be only $6 \%$ greater than the baseline vehicle. Additional research is needed to identify the battery materials that bring about these increases in hazardous waste levels.

\subsection{HAZARDOUS WASTE ASSESSMENT}

The assessment of the total waste stream from the extraction and materials processing stage, above, estimates the size of the hazardous waste stream associated with the baseline and $3 \mathrm{X}$ vehicles. It does not, however, provide information about the make-up of that hazardous waste stream. Characterizing the hazardous waste stream, particularly the wastes associated with materials processing, was the purpose of the assessment documented here.

\subsubsection{Methods, Assumptions, and Qualifiers}

This assessment uses 1999 data available from EPA's Toxics Release Inventory (TRI) (EPA 2000b) and the Environmental Defense's Chemical Scorecard, which is based on TRI data. Although the TRI reports releases of toxic substances rather than of "hazardous waste" as defined by U.S. Federal law (specifically the Resource Conservation and Recovery Act or RCRA), we make the assumption that the releases to land, water, and off-site transfer are hazardous wastes. The U.S. EPA has developed a "Chemical-RCRA Waste Code Crosswalk" that shows the relationship between toxic chemicals and hazardous wastes (EPA 1997b).

The TRI is organized by SIC (standard industrial classification) Code. In it, industries report their releases to land, water, and off-site transfer - all of which are included in this assessment — as well as emissions to air — which are excluded. By using these companyreported releases and company-reported or USGS-reported (USGS 2000) materials production, a mass of releases per unit of material produced was calculated. This release-perproduction number was then multiplied by the mass of the material in each of the vehicles to determine how much of each particular release would result from the production of each of the automotive materials considered here. The like releases were then summed across all materials (e.g., cadmium releases from each of the materials in the ESX2 were summed).

For SIC codes that report more than one material type, USGS Minerals Yearbook (USGS 2000) information was used to identify the total U.S. production of each of the materials within that SIC. To determine releases for a material that is within a multi-material SIC, the proportion of material of concern to total material within the SIC was applied to the total releases of that SIC. This procedure was used for the minor metals, e.g., magnesium and nickel.

This analysis covers many, but not all, of the predominant materials in the $3 \mathrm{XVs}$ and their potential new battery types. Specifically, it addresses wastes derived from the production of steel, aluminum, titanium, magnesium, platinum, lithium, and nickel. It does not include fibers and plastics, which are significant replacement materials in the ESX2 and the P2000. 
Plastics were found to be significant contributors of hazardous waste in the "Total Waste" assessment reported in Section 2.1. Also, the analysis addresses 24 different chemicals listed on the Toxics Release Inventory, specifically those emitted in the production of the materials addressed here and also listed as the most hazardous to human health and the environment in the Chemical Hazard Evaluation developed at the University of Tennessee's Energy, Environment, and Resources Center for the U.S. EPA (Davis et al. 1994). For these reasons, and because this analysis focuses on materials processing and excludes extraction wastes, the changes in mass of hazardous waste reported in this section can differ significantly from those reported in Section 2.1 Again, the purpose of this assessment is to help characterized the hazardous waste stream associated with $3 \mathrm{XVs}$.

The quality of this assessment rests on the quality of the Toxic Release Inventory data, which, like most waste and release data, are industry recorded and reported, and made public by the U.S. EPA. Limitations of TRI include a threshold below which industries are not required to report releases and the exclusion of many potentially harmful chemicals.

\subsubsection{Hazardous Wastes from Select 3XV Materials}

Table 2.5 presents the results of this analysis. It compares the baseline and the $3 \mathrm{XVs}$ ' releases of specific hazardous chemical wastes during the materials processing stage. (Recall that this addresses changes in seven materials, not the entire content of the baseline or 3XVs.) The introduction of new materials has significantly affected releases of some hazardous wastes.

Processing the $3 \mathrm{XV}$ materials included in this analysis appears to reduce production of between $18-20$ of the 24 wastes included in the assessment. Of these reduced wastes, twelve show a pattern of $-77 \%,-76 \%$, and $-43 \%$ for the P2000, ESX2, and the Precept, respectively. This pattern reflects the percentage decrease in the use of steel in these vehicles, compared to the baseline vehicle. In these twelve cases, processing of the substitute materials does not produce these release types (as reported in the TRI). In the remaining cases of waste reduction, the releases from production of substitute, lightweight materials are less than the releases from the steel they displace.

For the P2000 and Precept, releases of five toxic wastes increase. Among these five are PCBs (polychlorinated biphenyls), ${ }^{\mathrm{b}}$ copper, and chlorine, whose output is boosted by the production of the alternative metals. Despite these results, release of PCBs will not increase because they occur only in older equipment currently being retired. Also among the increases are nickel and ammonia, which experience huge increases almost entirely because of the nickel production for the nickel-metal hydride battery. For the ESX2, neither nickel nor ammonia increases because these releases result almost exclusively from nickel production for the nickel-metal hydride battery, which is the battery assumed for the P2000 and the Precept. The lithium-ion battery is assumed for the ESX2, and the production of lithium for the lithium-ion battery results in the release of $1.8 \mathrm{lbs}$ of lithium carbonate per vehicle (as delivered). A percentage increase cannot be calculated because this release type does not occur in the baseline vehicle.

\footnotetext{
${ }^{\mathrm{b}}$ Although PCBs are no longer manufactured, they still appear in TRI data. Their occurrence is associated with the disposal of capacitors and transformers, which until 1979 used PCBs (ATSDR 1993).
} 


\begin{tabular}{|c|c|c|c|c|c|c|c|}
\hline \multirow{3}{*}{$\begin{array}{l}\text { Emission } \\
\text { Chromium }\end{array}$} & \multirow{3}{*}{$\begin{array}{c}\begin{array}{c}\text { Baseline } \\
\text { (lbs) }\end{array} \\
0.0524\end{array}$} & \multicolumn{6}{|c|}{ 3XV(lbs* and \% change) } \\
\hline & & \multicolumn{2}{|c|}{ P2000 } & \multicolumn{2}{|c|}{ ESX2 } & \multicolumn{2}{|c|}{ Precept } \\
\hline & & 0.0175 & $-67 \%$ & 0.0169 & $-68 \%$ & 0.0380 & $-28 \%$ \\
\hline Cadmium & 0.0004 & 0.0001 & $-77 \%$ & 0.0001 & $-76 \%$ & 0.0002 & $-43 \%$ \\
\hline PCBs & 0.0001 & 0.0003 & $+256 \%$ & 0.0002 & $+118 \%$ & 0.0005 & $+450 \%$ \\
\hline Lead & 0.0379 & 0.0086 & $-77 \%$ & 0.0092 & $-76 \%$ & 0.0218 & $-43 \%$ \\
\hline Nickel & 0.0285 & 1.0270 & $+3497 \%$ & 0.0069 & $-76 \%$ & 2.7612 & $+9571 \%$ \\
\hline Anthracene & 0.0001 & 0.0000 & $-77 \%$ & .0 .0000 & $-76 \%$ & 0.0001 & $-43 \%$ \\
\hline $\begin{array}{l}\text { Hydrogen } \\
\text { fluoride }\end{array}$ & 0.0028 & 0.0006 & $-77 \%$ & 0.0007 & $-76 \%$ & 0.0016 & $-42 \%$ \\
\hline Copper & 3.9278 & 13.9687 & $+256 \%$ & 8.6135 & $+199 \%$ & 21.5531 & $+489 \%$ \\
\hline $\begin{array}{l}\text { Hydrogen } \\
\text { cyanide }\end{array}$ & 0.0071 & 0.0017 & $-75 \%$ & 0.0019 & $-73 \%$ & 0.0043 & $-40 \%$ \\
\hline Styrene & 0.0000 & 0.0001 & $-77 \%$ & 0.0001 & $-76 \%$ & 0.0000 & $-43 \%$ \\
\hline Ammonia & 0.0037 & 0.1396 & $+3675 \%$ & 0.0019 & $-49 \%$ & 0.3739 & $+10012 \%$ \\
\hline Nitric acid & 0.0135 & 0.0031 & $-77 \%$ & 0.0033 & $-76 \%$ & 0.0078 & $-43 \%$ \\
\hline $\begin{array}{l}\text { Trichloro- } \\
\text { ethylene }\end{array}$ & 0.0000 & 0.0000 & $-77 \%$ & 0.0000 & $-76 \%$ & 0.0000 & $-43 \%$ \\
\hline $\begin{array}{l}\text { Ethylene } \\
\text { glycol }\end{array}$ & 0.0005 & 0.0001 & $-77 \%$ & 0.0001 & $-76 \%$ & 0.0003 & $-43 \%$ \\
\hline Napthalene & 0.0020 & 0.0005 & $-76 \%$ & 0.0005 & $-75 \%$ & 0.0012 & $-40 \%$ \\
\hline Phenathrene & 0.0008 & 0.0002 & $-72 \%$ & 0.0002 & $-72 \%$ & 0.0005 & $-34 \%$ \\
\hline Phenol & 0.0050 & 0.0011 & $-77 \%$ & 0.0012 & $-76 \%$ & 0.0013 & $-43 \%$ \\
\hline $\begin{array}{l}\text { Phosphoric } \\
\text { acid }\end{array}$ & 0.0015 & 0.0003 & $-77 \%$ & 0.0004 & $-76 \%$ & 0.0009 & $-43 \%$ \\
\hline Zinc & 0.4740 & 0.1075 & $-77 \%$ & 0.1159 & $-76 \%$ & 0.2734 & $-43 \%$ \\
\hline Antimony & 0.0001 & 0.0000 & $-77 \%$ & 0.0000 & $-76 \%$ & 0.0000 & $-43 \%$ \\
\hline Chlorine & 0.0001 & 0.0005 & $+323 \%$ & 0.0003 & $+176 \%$ & 0.0008 & $+559 \%$ \\
\hline Manganese & 0.0970 & 0.0681 & $-30 \%$ & 0.0506 & $-48 \%$ & 0.1241 & $28 \%$ \\
\hline $\begin{array}{l}\text { Lithium } \\
\text { carbonate** }\end{array}$ & 0 & 0 & - & 1.8083 & Increase* & 0 & 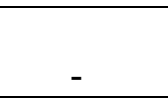 \\
\hline
\end{tabular}

*Some masses are so small that they round to 0.0000 .

**Lithium carbonate is not emitted in the production of materials other than lithium, thus it applies only to the ESX2 with its lithium ion battery.

\subsection{AUTOMOBILE SHREDDER RESIDUE AND HAZARDOUS WASTE MANAGEMENT CAPACITY ISSUES}

An alteration in material weight or composition in $3 \mathrm{XVs}$ most likely will result in a change in waste management requirements, particularly when considering the manufacturing process of automobiles from a life-cycle perspective. In this chapter, we examine two waste management issues related to $3 \mathrm{XVs}$ : changes in automotive shredder residue (ASR) at the vehicles' end-oflife stage, and hazardous waste management capacity demands throughout the vehicles' lifecycle based on the Resource Conservation and Recovery Act of 1976 (RCRA), the United States' major hazardous waste legislative act. 


\subsubsection{Methods and Assumptions}

The ASR analysis uses information about the material inputs in the baseline and 3XVs, current components of ASR, and existing recycling practices to determine the weight and composition of each vehicle type's ASR. We present the weight and materials of the 3XVs at their end-of-life. We then calculate the percentage of the weight and the materials that remain for solid waste management because they will not be recycled. ASR is classified as a nonhazardous waste under the current Federal hazardous waste regulatory framework and is disposed most frequently in municipal solid waste landfills, as opposed to hazardous waste landfills. An exception to the nonhazardous designation is made if a sample of the waste stream reveals metals content above threshold levels established in RCRA regulation. ${ }^{\mathrm{c}}$ As this is seldom the case, we assume in this report that the metals content of ASR is below the threshold level.

Next, the demand for commercial hazardous waste treatment, storage, recycling, and disposal capacity arising during the extraction and materials processing and end-of-life stages is assessed. Specifically, the assessment considers whether sufficient hazardous waste management capacity exists to meet future waste management demand. As in the total waste assessment reported in Section 2.1, waste classified in the European data as "regulated hazardous waste" is assumed to be the equivalent of hazardous waste as defined by U.S. Federal waste management regulatory programs. Although hazardous waste represents only a small fraction of the vehicles' total waste stream, this assessment focuses on it because of Federal regulatory requirements for its management.

The analysis in this chapter is based on current U.S. Federal hazardous and solid waste management policies, although states do have regulatory authority to set environmental standards more stringent than national standards set by EPA. One example of more-stringent state regulation is California's handling of ASR. In the late 1980s, California required that ASR meet minimum treatment standards for various metal components before it could be land disposed in a municipal solid waste landfill. Another example of more stringent state environmental policies concerns hazardous waste reporting. Tennessee requires that small quantity generators (those generators generating 100 to $1000 \mathrm{~kg}$ of hazardous waste per month) report their hazardous waste generation through the Federal Resource Conservation and Recovery Act of 1976. EPA does not require reports on hazardous waste generation from small quantity generators (EPA 1999).

We recognize that European hazardous and solid waste regulations may differ from those in the United States. The relevant difference for this analysis is the regulatory definition of hazardous waste, i.e., what chemicals found in waste streams are defined as hazardous. The relationship between U.S. and Europeans waste categories is discussed in Section 2.3.7.1 waste.

\footnotetext{
${ }^{\mathrm{c}}$ See Subpart B, "Criteria for Identifying the Characteristics of Hazardous Waste and for Listing Hazardous Wastes," 40 CFR $\S \S 261.10$ and .11, 2000; Subpart C, "Characteristics of Hazardous Wastes," 40 CFR, $\S \S 261.20-261.24,2000$; Subpart D, "Lists of Hazardous Wastes," 40 CFR $\S \S 261.30-261.35$, 2000; and Appendices I through IX 40 CFR 2000).
} 
The one area of state law on which this analysis focuses is state laws that ban landfilling of whole tires. Although it is a state-led, not Federal, policy, the banning of landfilling of whole tires affects the composition of materials for disposal or recycling at the end-of-life phase of vehicles.

Finally, we acknowledge that new markets are developing for recycled plastics and other remaining components of ASR (see, for example, Buchholz 2000). For this report, however, we assumed current recycling practices for ASR.

\subsubsection{Overview of the Federal Waste Management Regulatory Framework}

EPA's Office of Solid Waste has primary regulatory responsibility for Federal waste management programs. It broadly defines three waste categories: hazardous waste as defined under Subtitle C of the Resource Conservation and Recovery Act of 1976 (RCRA), municipal solid waste as regulated under Subtitle D of RCRA, and industrial and special waste. Hazardous wastes are wastes that exhibit certain characteristics (e.g., ignitability, corrosive, toxicity, or reactive). In addition, EPA may list a specific hazardous waste (e.g., treatment sludge).

Under RCRA authority, EPA has defined hazardous waste as solid, semisolid, liquid, and gaseous materials from industrial, commercial, agricultural, and community activities. In addition to defining hazardous wastes through RCRA, EPA also developed a regulatory framework that identifies wastes that must be managed as hazardous waste. Through that regulatory framework, EPA defines a waste as hazardous if it:

- Exhibits any of the characteristics of a hazardous waste defined by standard analytical test protocols and procedures,

- Is listed as a specific hazardous waste (under Subtitle C, RCRA),

- Is a mixture that contains a listed hazardous waste and other wastes,

- Has not been excluded from RCRA regulations as a hazardous waste (emphasis added), or

- Is a byproduct of the treatment of any hazardous waste (unless specifically excluded from RCRA) (Wentz 1995, p. 78).

About 40 million tons of hazardous waste were generated in the United States in 1997 by large quantity generators (EPA 1999). Hazardous waste must be managed in permitted hazardous waste treatment, storage, recycling, or disposal facilities. Treatment standards for hazardous waste are defined in 40 CFR $\$ 268$ (2000). Despite the definition of hazardous waste as waste that exhibits certain characteristics, some waste streams may be exempted from hazardous waste regulation, including some mining/mineral wastes and slags/ashes, which will be discussed below.

Municipal solid waste is commonly thought of as garbage generated from households, businesses, and industries. EPA classifies municipal solid waste as: 
Garbage, or refuse, sludge from a wastewater treatment plant, water supply treatment plant, or air pollution control facility and other discarded material, including solid, liquid, semi-solid, or contained gaseous material resulting from industrial, commercial, mining, and agricultural operations, and from community activities (EPA 2001a).

Municipal solid waste can be recycled, incinerated, sent to a waste-to-energy facility, or disposed in a municipal solid waste landfill. States handle permitting procedures for municipal solid waste facilities. EPA has set standards for air emissions from incinerators and waste-to-energy facilities and liner requirements for municipal solid waste landfills. Otherwise, states are responsible for ensuring proper management of municipal solid waste. U.S. generation of municipal solid waste in 1998 was close to 220 million tons. More than half of this waste was managed in municipal solid waste landfills $(55 \%)$, with the remainder recycled (27\%) and incinerated (17\%) (EPA 2000a).

Industrial waste (sometimes referred to as nonhazardous industrial waste) is a process waste associated with manufacturing and is generated by a wide range of industries. Industrial waste is not classified as either municipal solid waste or hazardous waste by Federal or state laws. State governments have regulatory authority for ensuring proper management of industrial waste, but these programs vary widely. Each year about 7.6 billion tons of industrial wastes are generated (EPA 2001b).

\subsubsection{Current Recycling Practices}

Vehicles are recycled at a higher rate than most recycled products in the United States. Of the approximate 9-11 million cars taken out of service each year, EPA estimates that close to 95 percent will be recycled through dismantling, shredding, and recycling processes (EPA 1995b; Automotive Engineering 1992). Three operations are primarily responsible for vehicle recycling: automobile scrappage/disassembly, automobile shredders, and materials recycling. All are in Standard Industrial Classification (SIC) code 37-transportation equipment.

One primary dismantling step is to remove hazardous and recyclable fluids (oil, auto coolants, CFCs) and batteries (EPA 1995b). Another step is for dismantlers to take off the high-value parts for reuse and reconditioning. Components such as body panels, water pumps, and alternators may serve as repair or replacement parts (Automotive Engineering 1992). The remaining parts of the auto are sent to shredders.

Shredders shred cars into small-sized particles that are processed through magnetic separators and air classifiers. There are three major fractions that result from a shredding process: ferrous scrap, nonferrous scrap, and automotive shredder residue (ASR) or "fluff" (Automotive Engineering 1992; Lanoir et al. 1997; EPA 1995b). Magnetic separators recover the ferrous materials, while nonferrous metals are generally hand-sorted from a conveyor belt. EPA reports that approximately 11 million tons of recycled steel and 800,000 tons of nonferrous metals are recovered annually (EPA 1995b). Similar quantities are reported in Automotive Engineering (1992). The remaining material is ASR. 
Currently, about 75 percent of the weight of vehicles is recycled for raw material use (EPA 1995; Berry 1992, Davis 1997). Nevertheless, there is still demand for solid waste landfill capacity for the remaining 25 percent, estimated at about 2.5 to 3 million tons disposed each year (Curlee et al. 1994; Klempner et al. 1999). EPA estimates that ASR constitutes about 1.5 percent of the total municipal landfill waste (EPA 1995b).

\subsubsection{Automotive Shredder Residue (ASR) Composition}

The first step in calculating the percentage of weight and material composition of the likely ASR from the three $3 \mathrm{XVs}$ is to determine the current characteristics of ASR. ASR is a lightweight mixture of several materials; its precise contents and percentages of materials varies from sample to sample. Although numerous characterization studies agree that ASR comprises plastics, glass, rubber, fiber, and dirt, they are not consistent with respect to the proportion of these materials in ASR. The disparity is partly the result of the research focus of each characterization study.

For example, one study characterizing ASR investigated the viability of incinerating ASR (Lanoir et al. 1997). The study focused not only on the ASR entering the incinerator, specifically plastics and metals that might be small fragments in the plastics, but the ash content of the incinerator. Another study addressed ASR composition from the perspective of issues of heavy-metal content and toxic emissions during incineration (Fisher and Mark 1999). Yet another study examined treatment standards for metals before land disposal and focused on cadmium, chromium, copper, lead, mercury, nickel, zinc, and hexavalent chromium (Radimsky and Watson 1989).

Other studies focused on broader public policy recycling issues and listed ASR components as urethane foams, fabrics, vinyl upholstery, padding, rubber, plastics, glass, and dirt (Klempner et al. 1999; Winslow et al. 1998; EPA 1995). In some research, categories were combined so that ASR components are reported as (1) fabrics, paper, and wood or (2) metals, wire, and glass (EPA 1991). Of the numerous characterization studies reviewed, two had percentages of materials by weight that were reasonably close. These two representations of ASR are presented in Table 2.6. For references on percentages of ASR components, as well as references that discuss the general categories of ASR without weights by percentage, see Appendix A.

Finally, we examined treatment of tires, which is dictated largely by state rather than Federal law as noted above. More than 30 states ban whole tires from municipal solid waste landfills, while 12 states ban all scrap tires from landfills. More important, only five states place no landfill restrictions on tire disposal in municipal solid waste landfills (Rubber Manufacturers Association, no date). EPA reports that of the 266 million scrap tires generated in 1996, 24\% were landfilled, stockpiled, or illegally dumped (EPA 1999). This implies a fairly high recycling and/or reuse rate for tires. 


\begin{tabular}{|l|l|l|}
\hline Table 2.6. ASR Components as Reported by Two Sources (\% by weight) \\
\hline \hline \multirow{2}{*}{ ASR Component Material } & \multicolumn{2}{|c|}{ ASR content as reported by ... } \\
\cline { 2 - 3 } & $\begin{array}{l}\text { American Automobile } \\
\text { Manufacturers } \\
\text { Association } \\
\text { (Kincaid 1996) }\end{array}$ & $\begin{array}{l}\text { Automotive Engineering } \\
(1992)\end{array}$ \\
\hline \hline Plastics & 34 & 37 \\
\hline Fluids & 17 & 17 \\
\hline Glass & 16 & 16 \\
\hline Rubber & 12 & 12 \\
\hline Other* & 21 & 21 \\
\hline
\end{tabular}

\subsubsection{New Vehicle Material and ASR Balance}

This study compares the 1994 baseline vehicle's material composition by weight with the three 3XVs. Material composition and weight of the 1994 baseline car and 3XVs are presented in Table 2.2. Table 2.7 further breaks down some categories to better represent material inputs in terms of the potential components of ASR. This table includes categories for fluids and tires. The weight of the fluids has been taken from the "other" category, while the weight of the tires has been taken from the rubber, ferrous and "other" categories.

Table 2.8 presents the ASR likely to remain after recycling of each vehicle type. We assume that all of the plastics, resins, rubber (other than tire rubber), glass, glass fiber, and a broader "other" category remain as ASR after recycling. Other includes materials such as fabrics, carpets, urethane foams, and vinyl. We assume that $10 \%$ of the "other fluids," i.e., those other than fuel, remain after the fluids are drained and become part of the ASR. These categories are known components of ASR.

The $18 \%$ of the baseline vehicle's weight that we estimate to remain as ASR is less than the $25 \%$ reported in the literature (largely because of the composition of the baseline vehicle). Also the relative amounts of each material type are different than the breakdown reported in the literature, with the exceptions of plastics and glass.

The amounts of ASR resulting from the ESX2 and the Precept are estimated to be greater than the baseline vehicle's ASR; the weight of the ASR resulting from the P2000 is estimated to be less than the baseline vehicle's ASR, but account for a larger percentage of the vehicle's mass (23\%, compared to 18\%). The baseline vehicle, the P2000, ESX2, and Precept are estimated to have 582, 455, 910, and 719 pounds of ASR, respectively. These differences are despite the lower total weight of the 3XVs. The relatively high weight of ASR for the ESX2 results from the high plastics content, while for the Precept the category "other" is the largest contributor. 


\begin{tabular}{|l|r|r|r|r|}
\hline \multicolumn{5}{|c|}{$\begin{array}{c}\text { Table 2.7. Material Composition of the 1994 Baseline Vehicle and 3XVs, } \\
\text { Representing Potential ASR Components (lbs) }\end{array}$} \\
\hline \hline Material & $\mathbf{1 9 9 4}$ Baseline & P2000 & ESX2 & Precept \\
\hline Plastics & 193 & 209 & 52 & 187 \\
\hline Resins (for composites) & 28 & 40 & 428 & 86 \\
\hline Wrought Aluminum & 47 & 462 & 330 & 304 \\
\hline Cast Aluminum & 159 & 271 & 120 & 820 \\
\hline Magnesium & 6 & 86 & 122 & 7 \\
\hline Platinum ${ }^{l}$ & 0 & 0 & 0 & 0 \\
\hline Titanium & 0 & 11 & 40 & 33 \\
\hline Ferrous & 2153 & 475 & 513 & 471 \\
\hline Rubber (other than tires) & 98 & 82 & 107 & 36 \\
\hline Glass & 97 & 36 & 70 & 57 \\
\hline Lexan & 2 & 30 & 20 & 0 \\
\hline Glass Fiber & 19 & 19 & 60 & 35 \\
\hline Carbon Fiber & & 8 & 24 & 22 \\
\hline Fluid: Fuel & 106 & 42 & 42 & 32 \\
\hline Fluid: Other & 79 & 71 & 71 & 71 \\
\hline Tires & 100 & 100 & 100 & 100 \\
\hline Major metals in each \\
battery
\end{tabular}

1 There is $0.003 \mathrm{lbs}$ of platinum in the baseline and $0.01 \mathrm{lbs}$ in each of the $3 \mathrm{XVs}$.

${ }^{2}$ Lexan in the baseline vehicle is reported as plastics.

${ }^{3}$ The $100 \mathrm{lbs}$ for four tires includes $41 \mathrm{lbs}$ of rubber, $15 \mathrm{lbs}$ of steel, and $44 \mathrm{lbs}$ of "other." The rubber, ferrous, and "other" categories have been adjusted accordingly.

${ }^{4}$ The weights of lead, nickel, and lithium in the vehicles' batteries have been removed from the "other" category.

\begin{tabular}{|l|c|c|c|c|}
\hline \multicolumn{5}{|c|}{ Table 2.8. ASR Per Car at End-of-Life Phase (lbs) } \\
\hline \hline Material & 1994 Baseline & P2000 & ESX2 & Precept \\
\hline \hline Plastics (including resins) & 231 & 249 & 480 & 273 \\
\hline Rubber: Other & 98 & 82 & 107 & 36 \\
\hline Glass & 97 & 36 & 70 & 57 \\
\hline Glass fiber & 19 & 19 & 60 & 35 \\
\hline Lexan & 0 & 30 & 20 & 0 \\
\hline Carbon Fiber & 0 & 8 & 24 & 22 \\
\hline Fluid: Other & 8 & 7 & 7 & 7 \\
\hline Other & 129 & 24 & 142 & 289 \\
\hline $\begin{array}{l}\text { Total (\% of total vehicle } \\
\text { weight) }\end{array}$ & $582(18 \%)$ & $455(23 \%)$ & $910(40 \%)$ & $719(28 \%)$ \\
\hline
\end{tabular}




\subsubsection{Municipal Solid Waste Management Capacity}

This analysis assumes that the ASR does not meet the legal definition of hazardous waste under the sampling procedures set out in the Code of Federal Regulations, and thus would be landfilled in municipal solid waste landfills. Obviously, the need for ASR disposal capacity may change as new recycling methods for plastics and other materials are developed and become economically feasible.

No Federal regulatory provision exists for assessing national capacity of municipal solid waste disposal capacity. However, there is consensus that current national municipal solid waste management is adequate (EPA 2000a; Peretz 1997). There are no projections that challenge the capability to manage waste in the future. Although the number of solid waste landfills is declining, the remaining landfills are considerably larger than the closed, smaller units. In the early 1990s, few states had more than 10 years of disposal capacity. By 1995, only two states (New Jersey and Massachusetts) had less than five years' remaining capacity, and this appeared linked to state policies on recycling and source reduction. The shortfalls appear in regions, not nationwide.

\subsubsection{Hazardous Waste Management Capacity Requirements}

\subsubsection{Relating Different Waste Categorization Schemes}

Section 2.1 presents an analysis of wastes generated during the vehicles' extraction and material processing life-cycle stage that breaks down the total waste stream into five categories: mineral, mixed industrial, slags/ash, inert chemicals, and regulated chemicals. These categories are derived primarily from the source data, much of which is European, and although they are highly consistent with U.S. Federal waste categories, the two schemes are not thought to perfectly mirror each other. Nevertheless, for this analysis, we explicitly link European waste categories and U.S. waste categories (see Table 2.9).

\begin{tabular}{|l|l|}
\hline \multicolumn{2}{|l|}{ Table 2.9. Comparison of European and U.S. Waste Categories } \\
\hline \hline European waste categories & U.S. waste category \\
\hline \hline mineral & mining waste \\
\hline mixed industrial & industrial \\
\hline slags/ash & industrial \\
\hline inert chemicals & industrial \\
\hline regulated chemicals & hazardous waste \\
\hline
\end{tabular}

The following sections discuss U.S. Federal waste law relevant to each of these five categories. 


\section{Mining Waste}

RCRA specifically excludes certain mining wastes generated through the processing of ores and minerals from regulation as hazardous wastes. ${ }^{\text {d }}$ These exclusions include a number of different types of slag, process wastewater, dusts, and sludges from the processing of materials such as copper, lead, bauxite, phosphoric acid, coal, iron, magnesium, steel, zinc and others (40 CFR §261.4(b)(7)(ii), 2000).

In addition, wastes from the "extraction, beneficiation, and processing of ores and minerals" are exempted from regulation as a hazardous waste. Beneficiation, as defined, is restricted to specific activities, such as crushing, washing, dissolution, filtration, sorting, roasting, etc. (40 CFR $\$ 261.4(b)(7)(i), 2000)$. Also excluded from regulation as hazardous waste are secondary materials that are generated within the primary mineral processing industry, provided that the secondary material is legitimately recycled to recover minerals and the secondary material is not accumulated (40 CFR §261.4(a)(17), §261.4(a)(17)(i), and §261.4(a)(17)(ii), 2000).

However, if the exempted waste stream is mixed with other wastes exhibiting a characteristic of hazardous waste (ignitable, reactive, corrosive, or toxic), then the entire waste stream is regulated as a hazardous waste (40 CFR $\$ 261.3(\mathrm{a})(1)(\mathrm{i}), 2000)$; commonly referred to as the Bevill exclusions. In this analysis, we assume that this mixing does not take place.

\section{Mixed Industrial}

In this report, we assume that European mixed industrial waste is similar to U.S. industrial waste. Although industrial waste generation is copious, as noted above, it is not classified as either municipal solid waste or hazardous waste. EPA has left responsibility for proper management of this waste stream to each state, where programs vary widely. Moreover, because this examination focuses on currently adopted Federal programs, this waste stream falls outside its scope. It is important to bear in mind, however, that industrial waste is not regulated as a hazardous waste.

\section{Slags/Ashes}

Slags and ashes generated from the production of energy are exempt from RCRA regulation as a hazardous waste. Specifically, RCRA exempts from hazardous waste "fly ash waste, bottom ash waste, slag waste, and flue gas emission control waste, generated primarily from the combustion of coal or other fossil fuels" (40 CFR $\S 261.4(\mathrm{~b})(4), 2000)$. The non-regulation of coal wastes, including fly ash, was amplified recently when in April 2000 EPA announced that coal combustion wastes from electric power plants should not be regulated as hazardous. Instead the agency would develop national standards for management of this waste stream (Najor 2000). Those standards have not yet been published.

\section{Inert Chemicals}

We have assumed for this report that inert chemicals fall within the U.S. waste category, industrial waste, and do not meet the definition of hazardous waste.

\footnotetext{
${ }^{\mathrm{d}}$ Obviously, other waste streams might be generated through the mineral extraction process. If the waste meets the definition of hazardous waste, it falls under the RCRA regulatory regime.
} 


\section{Regulated Chemicals}

For this assessment, we consider regulated chemicals from the European data to be the equivalent of RCRA-regulated hazardous waste. As noted above, waste can be considered hazardous if it exhibits a certain characteristic (ignitable, reactive, toxic, or corrosive) or if EPA has listed it as a hazardous waste (there are more than 500 listed hazardous wastes). Hazardous waste generators must file annual reports with the states; states in turn submit biennial reports to EPA. There are restrictions on storage at the hazardous waste generating site, and the waste must be treated at a permitted treatment, storage, recycling, or disposal facility. Hazardous waste generation quantities are lower than industrial or municipal solid waste generation.

\subsubsection{Hazardous Waste Management Capacity}

A key question in this analysis is whether there is sufficient capacity to manage the hazardous waste likely to be generated through the manufacturing processes of the $3 \mathrm{XVs}$. Provisions in the Superfund Amendments and Reauthorization Act (SARA) of 1986 assist in this assessment. Section 104(c)(d) of SARA required that each state's governor certify to the EPA administrator on October 17, 1989 that the state had adequate capacity, either within its boundaries or through interstate agreement, to handle all the hazardous waste generated within its borders over the next 20 years. Any state failing to certify adequate capacity risked forfeiture of Federal Superfund cleanup funds. The states' 20-year projections accounted for economic growth, regulatory changes (such as newly identified RCRA hazardous waste), and waste minimization. All states submitted a capacity assurance plan in October 1989. Some states that lacked sufficient in-state capacity entered into interstate agreements. Other states, without sufficient waste management capacity in one waste-treatment method, projected that the capacity would be available over the next 20 years (most often through construction of a new facility). In its evaluation, EPA took a state approach rather than a clearly defined national approach to waste management; EPA did not declare inadequate any state capacity assurance plan, and no state had Superfund monies withheld (Peretz 1992).

A second round of capacity assurance plans were submitted to EPA in May 1994. The guidance offered by EPA for this round of submissions made it clear that the agency was assessing capacity from a national rather than state or regional perspective. In November 1994, EPA declared that adequate national capacity existed in all waste management categories. ${ }^{\mathrm{e}}$ Although the agency agreed to monitor waste management demand and remaining capacity available at waste management facilities, the agency has not conducted another round of capacity assurance plans and does not "anticipate the need to conduct another ... for the next few years" (EPA, 1995a). From this EPA determination it can reasonably be determined that sufficient waste management capacity exists to manage additional hazardous waste that would be generated from the manufacturing of $3 \mathrm{XVs}$.

\footnotetext{
${ }^{\mathrm{e}}$ Waste management categories assessed are: deepwell/underground injection; energy recovery of solids/sludges and liquids; fuel blending; wastewaters and sludges treatment; incineration of liquids/gases; inorganics recovery; incineration of sludges/solids; landfill; metals recovery; organics recovery; and stabilization (http://www.epa.gov/epaoswer/hazwaste/tsds/capacity/); accessed 2/28/01.
} 


\subsection{SPATIAL ASSESSMENT OF 3XV'' EXTRACTION AND MATERIAL PROCESSING PHASE}

Within the last decade, the U.S. has begun to address issues relating to the distribution of environmental impacts, and the potential for socially and economically disadvantaged populations to bear a disproportionate share of environmental burdens. These issues have been labeled issues of "environmental justice."

Issues relating to the distribution of environmental impacts are associated with each of the vehicles' life-cycle stages, and there are potential trade-offs between stages. As materials demand changes and wholly new materials are introduced to vehicle components, different geographic areas - and, thus, different populations - with reserves of select raw materials and processing capabilities may be affected. Also, at the end-of-life stage the volume and constituents of wastes may differ, having potential impacts in communities where the vehicle recycling and disposal occurs.

Another potential concern is the apparent tradeoff between impacts in the extraction and material processing stage and the use stage. Life-cycle analysis of two of the $3 \mathrm{XV}$ prototypes found that emissions of greenhouse gases $\left(\mathrm{CO}_{2}, \mathrm{CH}_{4}, \mathrm{~N}_{2} \mathrm{O}, \mathrm{SF}_{6}, \mathrm{CF}_{4}\right.$, and $\left.\mathrm{C}_{2} \mathrm{~F}_{6}\right)$, particulate matter, and NOx would all increase during the extraction and materials processing life-cycle stage and decrease during the use (fuel use) stage if low emission vehicle or ultra-low emission vehicle (LEV/ULEV) standards are met (Das et al. 2000). This pattern suggests a potential for impacts in vehicle use areas (the United States) to decrease, while impacts in materials production areas (foreign countries) could increase. Previous analysis of the rural vs. urban distribution of impacts also shows that for NOx and, especially, particulate matter, impacts will shift from urban areas to rural areas. This could be a potentially positive shift with regard to human health if the activities occur in less densely populated areas, but, conversely, it could have potentially negative effects if populations in these rural areas are of relatively poor health — due to economic status and access to health care — are exposed to the emissions.

In consideration of these issues, this analysis addresses the spatial distribution of materials extraction and processing activities to determine, at a gross scale, where potential environmental impacts associated with materials extraction and processing for $3 \mathrm{XVs}$ will occur. Although environmental impacts are possible at each life-cycle stage, this analysis addresses only the materials extraction and processing stage.

This analysis focuses on a limited set of materials: iron ore/steel, coal, bauxite/aluminum, titanium, magnesium, lithium, and platinum. It determines where - in which states and countries - materials extraction and processing activities will occur, and, thus, where associated environmental impacts - e.g., land erosion, ground water contamination, habitat destruction, and aesthetic degradation — and emissions — e.g., particulate matter $\mathrm{SF}_{6}$ might occur. This analysis does not attempt to determine the likelihood of any of these specific impacts. 
Analysts used a variety of information sources to determine where materials extraction and processing would be likely to occur for each of the seven materials addressed here (EPA 2000b, USGS 2000, National Mining Association 2001). The analysis identifies U.S. states and foreign countries that would experience reductions or increases in materials extraction and processing activities, and associated reductions or increases in environmental impacts. Reduced impacts occur because using less ferrous materials will bring about a reduction in environmental impacts from ore and coal mining. ${ }^{f}$ Conversely, there is potential for increased environmental impacts in locales where supplies of alternative metals, e.g., bauxite for aluminum, or platinum, are located. U.S. states that would experience changes in impacts are shown in Table 2.10. Countries likely to experience changes in impacts are identified in Table 2.11 .

Table 2.10. Select U.S. States Will Experience Changes in Environmental Impacts due to Material Demand for 3XVs

\begin{tabular}{|l|l|l|}
\hline \hline Reduced Impacts & Increased Impacts & Mixed Impacts \\
\hline \hline Minnesota (ore) & $\begin{array}{l}\text { Washington (magnesium, } \\
\text { aluminum) }\end{array}$ & $\begin{array}{l}\text { West Virginia (coal vs. } \\
\text { aluminum) }\end{array}$ \\
\hline Wyoming (coal) & Texas (magnesium) & Ohio (coal vs. aluminum) \\
\hline Kentucky (coal) & $\begin{array}{l}\text { New York (titanium, } \\
\text { aluminum) }\end{array}$ & \\
\hline & North Carolina (lithium) & \\
\cline { 2 - 2 } & Oregon (aluminum, titanium) & \\
\cline { 2 - 3 } & South Carolina (platinum) & \\
\hline
\end{tabular}

Table 2.11. Countries Where Environmental Impacts of Extraction and Material Processing for 3XVs Are Likely

\begin{tabular}{|l|l|}
\hline \hline Countries with Largest Increased Impacts & $\begin{array}{l}\text { Small, Developing Countries with Increased } \\
\text { Impacts }\end{array}$ \\
\hline \hline Canada (magnesium, lithium aluminum) & Guinea (aluminum) \\
\hline China (magnesium, aluminum) & Jamaica (aluminum) \\
\hline South Africa (titanium, platinum) & Sierra Leone (titanium) \\
\hline Australia (titanium, aluminum) & Chile (lithium) \\
\hline Russia (aluminum, magnesium, platinum) & Sri Lanka (magnesium, aluminum, lithium) \\
\hline
\end{tabular}

Every region in the United States could potentially experience some change in environmental impact with the introduction of new automotive materials. However, the scale of U.S. production of the lightweight metals is small compared to international activity, suggesting that U.S. impacts may decrease while impacts abroad might increase. The major aluminum producing countries - Canada, China, Australia, and Russia - are listed as those where the

\footnotetext{
${ }^{\mathrm{f}}$ This analysis considers only potential environmental impacts; it does not address localized economic impacts that might occur because of increased or decreased demand for a particular material.
} 
largest increases in impacts could occur. South Africa, a major producer of platinum and titanium, could also experience notable change. A number of small, developing countries have significant deposits of lithium, titanium, and aluminum and could experience increased demand for these resources. Although they do not have the production capacity of the larger countries listed in Table 2.11, their potential for environmental impacts may be the equivalent of the larger countries if these developing countries do not yet have a regulatory framework and the resources to administer such a framework to protect workers, the general population, and natural resources.

\subsection{Waste Assessment Conclusions and Recommendations}

The waste quantity assessments in Sections 2.1 and 2.2 demonstrate a likelihood that waste production will increase when lightweight materials replace steel and ferrous in automobiles. These projected increases are based on assumptions of current rates of recycling and current materials production practices and technologies. If recycling rates for aluminum increase, for example, these projected levels of waste will not be realized. However, assuming current practices, there are significant increases in the total quantity of waste associated with materials production for the new vehicles, and significant increases in hazardous waste, which is of special concern because it requires disposal at special waste repositories and presents potential human health affects.

The largest single contributor to the total waste of the $3 \mathrm{XVs}$ is aluminum, the extraction of which produces large volumes of mineral waste. Other lightweight metals, e.g., platinum, produce large quantities of mineral waste during their production; but because they are used in such small quantities in the new generation vehicles they contribute a relatively small amount of mineral waste. This category of waste is unregulated in the United States. It is unlikely, therefore, to present issues related to human health, although given the sheer quantity of production, better characterization of this waste stream appears warranted. Issues related to this type of waste involve land use, potential habitat destruction, and potential ground and surface water impacts.

The projected increases in hazardous waste production in vehicles (excluding batteries) result from plastics. The range of changes in hazardous waste-from a $26 \%$ decrease in the ESX2 to a $41 \%$ increase for the Precept - demonstrate that the selection of specific plastics has a significant impact on the quantity of hazardous waste associated with production of materials for the $3 \mathrm{XVs}$. Given this situation, future efforts should focus on selecting plastics that meet materials specifications (e.g., for strength and rigidity) yet are not large producers of hazardous waste.

Although the life-cycle assessment of the nickel metal hydride and lithium ion batteries provides a more comprehensive picture of their potential impacts, this assessment provides an in-depth look at one impact category, i.e., solid waste. Specifically, it shows that the new battery types, particularly the nickel metal hydride battery, has the potential to significantly increase the 3XVs hazardous waste output. The nickel metal hydride battery increased hazardous waste output by 160 percentage points; the lithium ion battery's effect was smaller, increasing hazardous waste output by 35 percentage points. The breakdown in Section 2.2 of 
constituents of the hazardous waste identify nickel as the primary contributor of two specific hazardous wastes, ammonia and nickel. The massive increases projected here are caveated by the quality of the TRI data on which they rely. Nevertheless, the wastes associated with these batteries warrant detailed investigation.

The detailed hazardous waste assessment does not include plastics and resins, which the overall waste assessment finds to be the primary contributor to the $3 \mathrm{XVs}$ ' hazardous waste generation at the materials extraction and processing stage. It is difficult to parse from TRI data which plastics are contributing to which specific emissions at the various manufacturing facilities. Additional analysis is needed to accomplish this task, which could aid in the selection of specific plastics for automotive applications.

Sections 2.3 and 2.4 are initial considerations of some of the implications of the waste increases projected in the assessments reported in Sections 2.1 and 2.2. The overview of RCRA hazardous waste testing and management standards reveals that ample waste management capacity exists in the U.S. to accommodate any additional demand associated with the $3 \mathrm{XVs}$ at end-of-life. The assessment does not address the demand for waste management capacity at the materials extraction and processing stage, largely because it is anticipated that much of the production and, thus, the demand for capacity will occur outside the United States. The spatial assessment in Section 2.4 confirms this likelihood, especially for the lightweight metals that are the focus of the spatial assessment. It less likely that the bulk of materials processing for resins and plastics will occur outside the United States because the United States remains a world leader in the production of plastics.

Although 3XVs present potentially large increases in the extraction and material processing waste in general and hazardous waste in particular, it is helpful to put these quantities in context. According to EPA estimates, of the 13 billion tons of industrial, agricultural, commercial, and household waste generated annually, two percent — or 279 million tons — are hazardous waste, as defined by RCRA regulations (U.S. EPA 1997a). By comparison, hazardous waste accounts only $0.2 \%$ or less of the extraction and materials processing waste for 3XVs. EPA also reports that Americans generate 1.6 million tons of hazardous household waste annually (this excludes industrial, agricultural, and commercial hazardous waste; U.S. EPA 1997a). This amounts to $12 \mathrm{lbs}$ per person annually. The materials for the Precept and P2000 would generate a slightly smaller amount of hazardous waste and the ESX2 would generate about one-third as much hazardous waste as each person in the U.S. generates in his own home annually. 



\section{LIFE-CYCLE ASSESSMENTS}

\subsection{INTRODUCTION TO THE LIFE-CYCLE ASSESSMENTS}

The life-cycle assessments, reported here and conducted by the University of Tennessee Center for Clean Products and Clean Technologies, address exterior body panels, hybrid electric vehicle batteries, and fuel cell vehicles. These assessments are the outgrowth of a previous study (Das et al. 2000, UT-CCPCT, 1999) that evaluated two PNGV prototype vehicles, the aluminum-intensive Ford P2000 and the composite-intensive DaimlerChrysler ESX2. That earlier study, in its conclusions, identified these three areas for future research work, recommending more detailed assessments involving carbon fiber composites, lithiumion batteries, and fuel cells. (A glossary of acronyms and terms is found in Appendix B.)

\subsubsection{The Life-Cycle Approach}

The environmental impacts associated with a vehicle based on newer technologies and using new generation materials can be more accurately and completely assessed if all the life-cycle stages are considered. The use of certain new materials may seem environmentally preferable in a particular life-cycle stage, but the new materials could produce significant environmental burdens in other life-cycle stages that the original materials did not, rendering their selection unjustifiable. Incorporating life-cycle considerations into the design process, therefore, is a proactive approach that prevents the imposition of unforeseen burdens on the environment by providing more complete information on potential impacts to product designers.

Life-Cycle Assessment (LCA) is a comprehensive method for evaluating the full environmental consequences of a product system. The four major components of an LCA are

1. Goal Definition and Scoping,

2. Life-Cycle Inventory (LCI),

3. Life-Cycle Impact Assessment (LCIA), and

4. Improvement Assessment.

Goal Definition and Scoping involves defining the functional and service units, and the boundaries that will determine the focus of the assessment. LCI involves the quantification of material and energy inputs, air emissions, liquid effluents, and solid wastes. This quantification results in an environmental profile for a product or product system. LCIA involves the translation of the inventory values into environmental impacts. The Improvement Assessment is the decision-making phase of an LCA, where opportunities to improve the environmental profile are explored by examining the LCA results.

\subsubsection{Life-Cycle Stages}

A LCA usually considers the following life-cycle stages:

Raw Materials Extraction

Activities related to the acquisition of natural resources from the earth and water; includes actions such as mining non-renewable material and harvesting biomass. For automobiles, major materials include iron, bauxite, and crude oil. 


\section{Materials Processing}

Processing of natural resources by reaction, separation, purification, and alteration, in preparation for the manufacturing stage. Examples include iron to steel, bauxite to aluminum, and crude oil to polymers.

\section{Manufacturing}

Production of components, parts, and sub-assemblies by manufacturers and their suppliers; assembly of automobiles by automakers.

\section{Use, Maintenance, and Repair}

Use of products by their owners. For complex electronic and/or mechanical products such as automobiles, includes regular maintenance and repair, conducted by the users themselves or by servicing facilities. In these assessments, 'Fuel Use' (also called driving) and 'Fuel Production' combine to make up the Use life-cycle stage.

\section{End-of-Life}

Disposition of products at the end of their useful lives. Options include landfilling, recycling, incineration, and, where possible, reuse. For vehicles and vehicle components at the end of their useful lives, processing includes dismantling, shredding, ferrous and nonferrous metal separation, and ultimate disposal of automobile shredder residue (ASR) either in landfills or through incineration.

Additionally, there is some other terminology that is used to describe life-cycle stages in LCA. "Cradle-to-Gate" is often used to define the combination of Extraction, Materials Processing, and Manufacturing, while "Cradle-to-Grave" refers to all the stages. "Upstream" is a term that is often used to refer to the stages that occur before the stage of interest (e.g., if reviewing EOL information, 'upstream' would refer to Extraction through Use); similarly, "downstream" is also used to refer to those stages coming after the stage of interest.

\subsubsection{Life-Cycle Data}

Each unit process in the life cycle of the automobile or automotive component (or any product) is characterized by a list of inputs and outputs associated with it, as depicted in Figure 3.1 below:

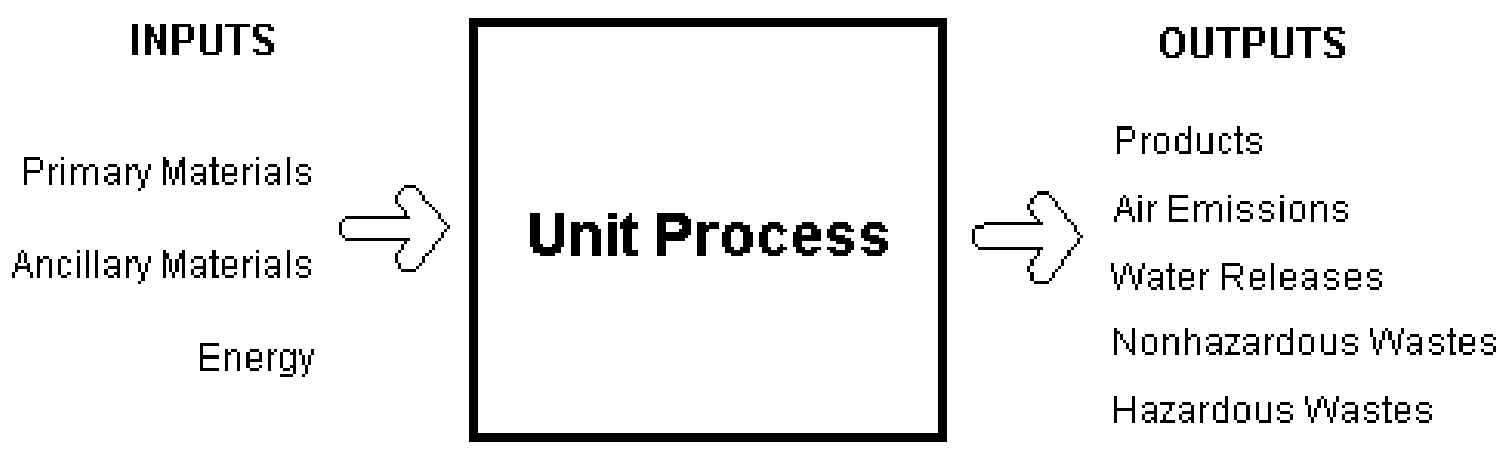

Figure 3.1. LCI Inputs and Outputs to a Unit Process 
All inventory data is collected and normalized to the functional unit and service unit of the product. The functional unit is the quantity or mass of a product that is traversing its entire life (all life-cycle stages); the service unit is the quantification of the Use life-cycle stage, which can be measured in various units. For an automobile, the functional unit could be one car, and the service unit would typically be a useful life of around 120,000 miles.

Within inventory data, the data categories typically include:

\section{Material Inputs}

- Primary Materials (materials that become part of the product)

- Ancillary Materials (materials needed in processing that are not "primary")

Energy Inputs

- Fuel or Process Energy

- Feedstock Energy (energy embodied in the product)

- Transportation Energy

Emissions and Wastes

- Air Emissions

- Water Releases and Emissions

- Nonhazardous Wastes

- Hazardous Wastes

Products

- Primary Products

- Co-products

An issue that often comes up in managing inventory data is allocation. Most often, in cases where a unit process results in multiple products or co-products, the inputs and outputs associated with the process are allocated between the products and co-products on a mass basis.

Also, with regard to life-cycle data, it should be noted that the results that are obtained from any LCA are greatly dependent on the assumptions made and the data used in the LCI. This partly explains why two different study groups can perform an LCA on the same product and derive differing sets of results. In these analyses, some additional information is provided to help see some of the variation that exists in LCI data. One example is in the FCV assessment, in the discussion around Table 3.24, while Appendix D provides more examples of data variation.

\subsubsection{Impact Categories}

After obtaining the LCI for the product, the next step is LCIA, where individual inputs and outputs are assigned to specific impact categories based on the known characteristics of each. After this assigning, each functional unit-normalized inventory value becomes an impact 
"score," and the impact scores for all inventory items are summed within each impact category to create the final, total values or scores for each impact category.

Within LCIA, there are a multitude of impact assessment methodologies that exist and are currently used by different LCA practitioners. The one chosen for use by (and partially developed by) the CCPCT is the "CHEMS, plus" methodology, which is the baseline methodology set up for use in the Life-Cycle Design (LCD) Toolkit (see below). Within most LCIA methodologies, a single input or output may contribute to more than one impact category, and multiple inputs and outputs can contribute to the same impact category. The range of potential impact categories included in the "CHEMS, plus" LCIA methodology are listed below:

- $\quad$ Nonrenewable resource use/depletion*

- Renewable resource use*

- $\quad$ Energy use*

- Global warming*

- $\quad$ Stratospheric ozone depletion*

- $\quad$ Photochemical smog*

- $\quad$ Acidification*

- $\quad$ Particulate matter*

- $\quad$ Aesthetic impacts*

- $\quad$ Solid waste landfill space*

- Hazardous waste landfill space*

- Radioactive waste landfill space

- $\quad$ Radioactive releases

- Water eutrophication or nutriphication (nutrient enrichment)*

- Water quality (BOD*, suspended solids*, and $\mathrm{pH}$ )

- $\quad$ Acute occupational human health effects

- Chronic occupational human health effects

- $\quad$ Acute consumer human health effects

- Chronic consumer human health effects

- $\quad$ Acute local population human health effects

- Chronic local population human health effects

- Aquatic toxicity

- Terrestrial ecotoxicity

The majority of the impact categories listed here - those marked with an asterisk $(*)$ - were included in the three assessments, however, some were excluded due to the unavailability of data for certain materials and processes. See Appendix $C$ for definitions of the impact categories included in the assessments.

For each of the three assessments, results have been presented for the impact categories identified in the above list, using the Life-Cycle Design Toolkit developed by the University of Tennessee CCPCT, under the dual sponsorship of the U.S. EPA and the Saturn Corporation (UT-CCPCT 2000). The LCD Toolkit enables product designers to assess the environmental impacts associated with major and minor design modifications, such as the use of alternate materials or components, fastening systems, and manufacturing processes. It provides 
interfaces for entering and organizing LCI data, building environmental profiles around that data, and comparing results to identify the life-cycle stages, processes, and/or materials that account for the greatest environmental burdens. The LCD Toolkit's results are expressed in terms of scores for each impact category that can be broken down by life-cycle stages or individual processes, or can be attributed to individual materials.

\subsection{METHODOLOGY AND OVERALL ASSUMPTIONS}

\subsubsection{Methodology}

Once the scoping work was completed, the materials breakdown was obtained for each of the three assessments (i.e., body panels, NiMH and LiIon HEV batteries, and ICEVs and FCVs). Certain assumptions had to be made where complete component or material breakdown information was not available. These assumptions are detailed in the individual sections for each assessment.

Existing secondary data sources were explored to find Extraction and Materials Processing (E\&MP) information on the materials involved in each of the three assessments. A secondary database that best fit the upstream data needs for these assessments was then selected. In cases where upstream data were missing or insufficient, attempts were made to obtain the data from other primary or secondary sources. Processes in the other life-cycle stages, Manufacturing, Use, and End-of-Life (EOL), were simultaneously identified. Efforts were then made to obtain materials, energy, and emissions information for these processes. This led to the identification of additional materials needed in the analyses, such as fuels and ancillary materials.

Once all the LCI data on each process were obtained, all process data were entered into the LCD Toolkit via the Process Builder (an interface used to build process-level data in the Toolkit). The processes were then linked within the Profile Builder to create environmental profiles ready to be analyzed, one for each product being considered. The profiles were then analyzed in the Toolkit. The results of each analysis were outputted in the form of impact scores, and each set of results was compared against the others in that assessment (the baseline versus the alternatives and the alternatives versus the alternatives). (For definitions of the impact categories and the units that are used in each category, see Appendix C: Impact Category Definitions.) For example, the impact scores obtained from analyzing the profile for the NiMH HEV battery were compared against the scores for the LiIon HEV battery.

Additional long-term (LT) analyses, based on future technological trends, targets, and/or ongoing research, were conducted for each of the three assessments. While the baseline analyses are focused on technology currently employed or in development, the long-term ones are based more on assumptions based on long-term PNGV and DOE targets. The future scenarios considered are

- A switch to a CFRP-based "monocoque"g car body design

\footnotetext{
${ }^{\mathrm{g}}$ A monocoque is a rigid shell or exoskeleton that is meant to absorb all or most of the stresses to which the vehicle body is subjected, and requires no other structures or subsystems to maintain system integrity.
} 
- Reduced-weight HEV batteries with longer life spans

- Reduced-weight reformer-based FCVs containing much less platinum than current designs

\subsubsection{Overall Assumptions}

Data for the E\&MP life-cycle stages were obtained mostly from the Data for Environmental Analysis and Management (DEAM) database that forms part of the Tool for Environmental Analysis and Management (TEAM) software developed by the Ecobilan Group (1999).

Because manufacturing data were not readily available and given the time constraints of this study, it was not possible to obtain manufacturing data from primary sources. Moreover, the contribution made by the Manufacturing stage to the total life-cycle environmental impacts of automobiles is typically insignificant (UT-CCPCT, 2000; Keoleian, 1997). Thus, it was decided not to include data from this life-cycle stage in the assessments.

The Use stage for all three assessments was uniformly assumed to be 120,000 miles of driving, and includes Fuel Use and Fuel Production. The other assumptions made for the Use stage that were specific to each assessment are discussed in the individual sections that follow.

For the EOL stage, different assumptions were made for each of the three assessments, and they are discussed in the following sections.

\subsection{EXTERIOR BODY PANELS ASSESSMENT}

\subsubsection{Background and Scope}

Carbon fiber composites have successfully been used in aerospace applications to replace heavier materials, because of their light weight and high strength. Although the same benefits would be highly desirable in automotive applications, the high price of carbon fiber has inhibited its widespread use in the automobile industry. However, in the last few years, considerable work has been done in developing lower-cost carbon fiber for use in composites for automotive applications.

This life-cycle assessment was conducted to compare the potential environmental impacts from the production, use and disposal of automotive body closure panels made of carbon fiber-reinforced polymer (CFRP) composite material to those made of steel (as the baseline) and other lightweight materials, namely, aluminum and glass fiber-reinforced polymer (GFRP). These materials were defined by the PNGV as the ones of primary interest for automotive exterior panel lightweighting efforts (NRC 2000, p. 47).

For the baseline assessment, one set of steel automotive closure panels ( 4 door panels, the hood, and the deck lid), with a total weight of approximately 220 lbs (NRC 2000, p. 50), was 
chosen as the functional unit. The service unit was defined as a useful lifetime of 120,000 miles.

An additional assessment was performed that looked more carefully at carbon fiber's weight reduction potential for the whole vehicle. This long-term analysis (also called the "monocoque analysis") assumes a radical change from the conventional body design to a CFRP-based shell-like monocoque body construction. The results of this analysis provide an opportunity to evaluate the environmental impacts associated with replacing a much larger mass of steel with a carbon fiber-based composite material.

\subsubsection{Assessment-Specific Assumptions}

The assumptions that pertain to the assessment of CFRP composite body panels are described here. Assumptions about specific materials follow the general assumptions below.

1) The closure panels of a mid-size passenger car (consisting of the 4 doors, hood, and deck lid [trunk lid]) made of four different materials were compared in this assessment:

- Steel (the baseline material)

- Aluminum

- Carbon Fiber-reinforced Polymer (CFRP) Composite

- Glass Fiber-reinforced Polymer (GFRP) Composite

These are the materials the PNGV has determined are viable candidates for the replacement of a steel Body-in-White (BIW) and closure panels in the sixth PNGV review report (NRC 2000).

2) For this assessment, only the closure panels were followed through the life cycle. Thus, E\&MP included only the ore extraction and materials processing (preparation) of the material. In the Use life-cycle stage, only fuel consumption and emissions generation associated with the closure panels (not the whole car) were included. These Use stage values were calculated using the 1994 Taurus-class vehicle fuel efficiency and emissions as a baseline. In the EOL life-cycle stage, only the processing of these panels was included.

3) The Manufacturing life-cycle stage was excluded due to unavailability of data on the actual production of the closure panels from these four materials. However, as mentioned previously, this life-cycle stage is typically the one with the smallest impacts (along with the EOL stage).

4) Material substitution factors (Sullivan and $\mathrm{Hu}$ 1995) were used to calculate the necessary weight of each set of closure panels. The weight of a set of steel panels was first determined (from PNGV data) (NRC 2000, p. 50), and then the substitution factors were applied to obtain the weights of the closure panels produced from the other three materials. The substitution factors took into account issues such as manufacturability of the components, as well as the fact that it is not possible to go as low in mass as one might like with carbon fiber due to the resulting ultra-thin panel produced (Sullivan 2000). 
5) With regard to vehicle life, it was assumed that each closure panel would last the life of the vehicle.

6) In an effort to conduct a more complete analysis, secondary weight savings were incorporated. Also known as mass decompounding, the idea is that at each opportunity to reduce the overall weight of a vehicle through materials replacement, further weight savings are now possible in the other systems and subsystems that operate the vehicle (e.g., powertrain, chassis) due to having some of the previous burden removed. These other systems can now be reviewed to find potential material reductions within them. A factor of 50\% secondary weight savings (Das 2000) was used to estimate the effect. However, because the functional unit of the analysis is the exterior panels, secondary weight savings could only be integrated into the Use life-cycle stage, where the overall vehicle weight and subsequent vehicle fuel efficiency and emissions were modified.

7) In the EOL stage, it was assumed that ferrous and nonferrous materials are recovered and recycled, while all other materials (including composites) are landfilled as ASR. EOL processing was based on current processes of shredding and nonferrous metal separation (NFMS). The inputs and outputs for these processes were reduced to unit values and then multiplied by the quantity of ferrous, nonferrous or other material traversing EOL. All of the CFRP and GFRP, therefore, were assumed to end up as ASR (thus landfilled). All materials went through shredding, while only the aluminum panels went through NFMS.

\subsubsection{Steel Assumptions}

It was found that most automotive outer body panels are made of galvanized steel, a coldrolled type of steel that is post-treated with zinc to prevent rusting. It was also found that most steels that have post cold rolling treatments applied tend to be basic oxygen furnace (BOF) steel (mostly virgin) ${ }^{\mathrm{h}}$; thus, BOF type hot-rolled steel, followed by a cold rolling process, was assumed to be the material for steel closure panels. Data on galvanizing was not available and was therefore excluded. Figure 3.2 shows a graphical representation of the steel profile.

\subsubsection{Aluminum Assumptions}

It was determined that the average amount of recycled content in wrought aluminum used in automobiles is $11 \%$ (wrought aluminum is the type of aluminum typically used to manufacture automobile body panels) (AA 1998). Thus, it was assumed that average automotive wrought aluminum would be used to produce closure panels made with aluminum. Data on the production of $100 \%$ virgin and $100 \%$ recycled aluminum were mixed appropriately to produce an inventory for the $89 \%$ virgin $/ 11 \%$ recycled wrought aluminum (labeled "automotive wrought aluminum"). Figure 3.2 shows a graphical representation of the aluminum profile.

\footnotetext{
${ }^{\mathrm{h}}$ Steel is also produced in electric arc furnaces (EAFs), where 100\%-recycled steel is used to produce new steel.
} 


\subsubsection{CFRP Assumptions}

Based on discussions with several experts (Dearlove 2000, Gibson and Williams 2000, Sullivan, Johnson and DeVries 2000), it was decided that the most appropriate mix of carbon fiber (CF) with a polymer for this application would be a $30 \%$ by mass mix of CF in epoxy resin. This decision came out of the discussion that the mixing percentage is dependent on the polymer matrix used with the CF (the options typically being epoxy resin, a vinyl ester or polyester) (SAE 2000a), and the trade-offs involved. Figure 3.3 shows a graphical representation of the CFRP profile.

\subsubsection{GFRP Assumptions}

For GFRP, it was decided to use the same materials and same mix as was used in our previous study (UT-CCPCT 1999) that included an assessment of the body panels of the DaimlerChrysler ESX2 prototype: $85 \%$ PET with 15\% glass fiber (GF). Other options included using a higher mix of GF ( 20-40\%) with other polymers like epoxy or a vinyl ester. Figure 3.3 shows a graphical representation of the GFRP profile.

\subsubsection{Monocoque (LT) Analysis Assumptions}

A carbon fiber-based monocoque design was chosen to compare against the baseline of steel. The monocoque design chosen was General Motors' 1991 Ultralite concept car, which was built by Scaled Composites, LLC in Mojave, California. The mass of the CFRP monocoque (190.5 kg for the BIW, including closures) came from a study conducted by The Hypercar Center, Rocky Mountain Institute (Mascarin et al. 1995).

The equivalent quantity of steel in the baseline vehicle was estimated to be 1,077 lbs, starting with a body mass of 1,134 lbs (NRC 2000), which included the BIW (590 lbs), closure panels (220 lbs), and other body panels and attachment components. It was assumed that $5 \%$ of the total (about $57 \mathrm{lbs}$ ) would be hinges, fasteners, and other parts that would still be needed in the Ultralite. 


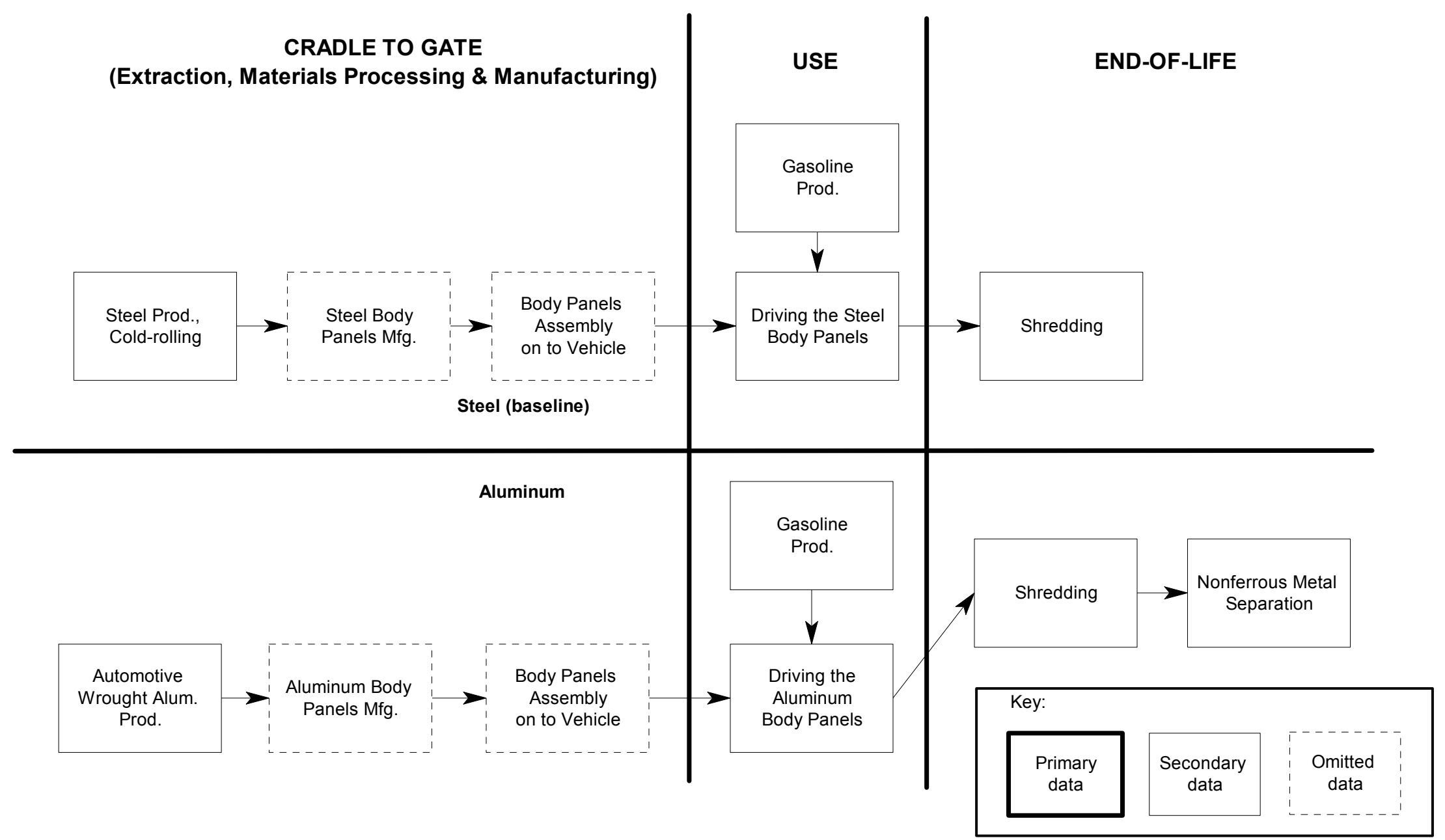

Figure 3.2. The Steel and Aluminum Profiles 
CRADLE TO GATE

(Extraction, Materials Processing \& Manufacturing)
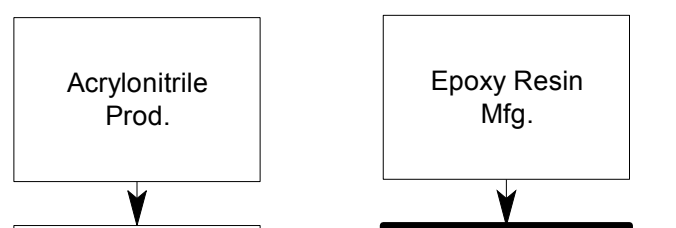

Acrylonitrile

Polymerization

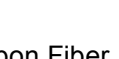

Carbon Fiber
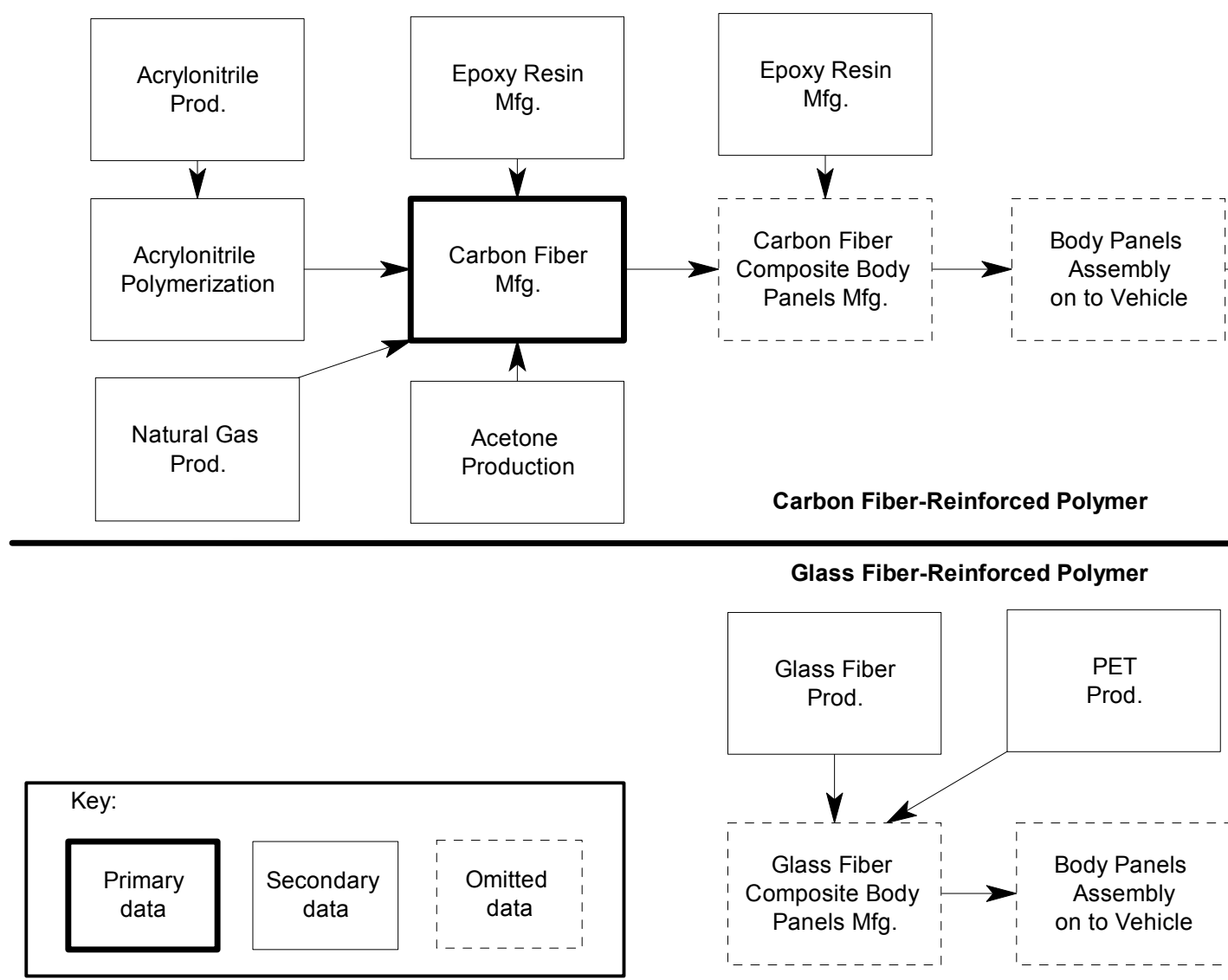

1

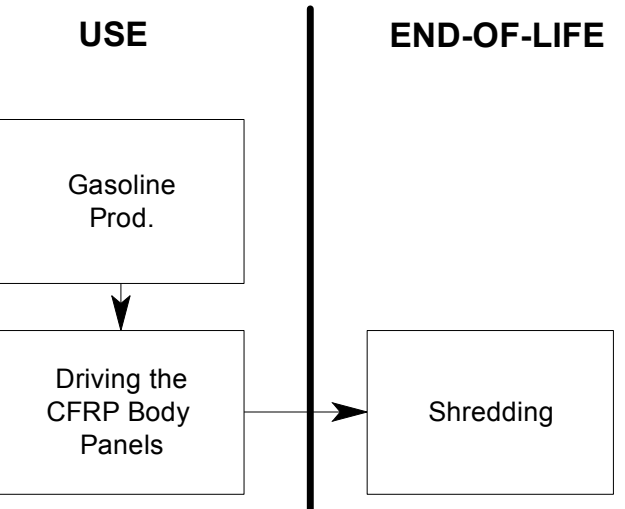

Figure 3.3. The CFRP and GFRP Profiles 


\subsubsection{Exterior Body Panel Results}

Based on the material characteristics assumed and substitution factors employed (see Section 3.1 ), the mass of each set of closure panels is provided in Table 3.1, along with the fuel efficiencies calculated and the lifetime quantity of fuel (gasoline) consumed in each case. As indicated in the table, the baseline vehicle had a mass of 3,248 lbs and a fuel efficiency of $26.6 \mathrm{mpg}$.

\begin{tabular}{|c|c|c|c|c|}
\hline \multicolumn{5}{|c|}{ Table 3.1. Profiles Evaluated for the Exterior Body Panels Assessment } \\
\hline & \multicolumn{4}{|c|}{ Profiles } \\
\hline & Steel & Aluminum & CFRP & GFRP \\
\hline Material type/composition & $\begin{array}{r}100 \% \text { virgin } \\
\text { cold-rolled } \\
\mathrm{BOF}\end{array}$ & $\begin{array}{r}89 \% \text { virgin } / \\
11 \% \text { recycled }\end{array}$ & $\begin{array}{r}30 \% \mathrm{CF} / \\
70 \% \text { epoxy } \\
\text { resin. }\end{array}$ & $\begin{array}{l}15 \% \mathrm{GF} / \\
85 \% \mathrm{PET}\end{array}$ \\
\hline Material substitution factor & 1.00 & 0.55 & 0.40 & 0.69 \\
\hline Mass of closure panels (lbs) & 220 & 121 & 88 & 152 \\
\hline Mass of vehicle (lbs) & 3,248 & 3,100 & 3,050 & 3,146 \\
\hline Vehicle fuel efficiency (mpg) & 26.60 & 27.45 & 27.74 & 27.19 \\
\hline $\begin{array}{l}\text { Lifetime fuel consumed by vehicle } \\
\text { (lbs) }\end{array}$ & 27,762 & 26,901 & 26,626 & 27,164 \\
\hline $\begin{array}{l}\text { Lifetime fuel consumed by panels* } \\
\text { (lbs) }\end{array}$ & 1,880 & 1,050 & 768 & 1,311 \\
\hline EOL disposition & Recycled & Recycled & ASR / landfill & $\begin{array}{r}\mathrm{ASR} / \\
\text { landfill }\end{array}$ \\
\hline
\end{tabular}

The impact scores obtained (see Table 3.2) indicate that CFRP is the least environmentally burdensome material in 9 of the 14 impact categories evaluated, which include nonrenewable and renewable resource use, energy use, global warming, acidification, odor/aesthetics, water quality (BOD), and landfill space (both hazardous and non-hazardous). Of the remaining five categories, GFRP has the lowest impacts in ozone depletion potential and PM formation, while aluminum has the lowest impact scores in the areas of smog formation, eutrophication, and water quality (TSS).

Steel has the highest scores in a number of impact categories, mainly because of its weight. The use of UltraLight steel, though, is believed to result in a weight reduction of approximately $32 \%$ when used for making closure panels (AISI 2001). This substantial reduction, if achieved, would enable steel to compete much better, environmentally, with the other lightweight materials. (UltraLight steel was not included in the analyses due to lack of data on its production.)

Comparison charts were created and are presented here to look specifically at the relationships between each alternative material and steel and between various alternative materials in all impact categories. 


\begin{tabular}{|c|c|c|c|c|c|}
\hline \multicolumn{6}{|c|}{ Table 3.2 Impact Scores for the Exterior Body Panels Assessment } \\
\hline Impact Category & Units & Steel & Aluminum & CFRP & GFRP \\
\hline \multicolumn{6}{|l|}{ Impacts from Inputs } \\
\hline Nonrenewable resource use & (lbs) & $2,983.09$ & $2,542.57$ & $1,396.95$ & $1,973.88$ \\
\hline Renewable resource use & (lbs) & $120,581.14$ & $59,929.76$ & $44,079.69$ & $73,235.42$ \\
\hline Energy use & (MMBTUs) & 44.24 & 37.02 & 22.11 & 32.02 \\
\hline \multicolumn{6}{|l|}{ Impacts from Outputs } \\
\hline Global Warming & (lbs $\mathrm{CO}_{2}$-eq.) & $8,474.52$ & $6,236.82$ & $4,055.77$ & $5,879.96$ \\
\hline Ozone Depletion & (lbs CFC11-eq.) & $9.18 \mathrm{E}-06$ & $3.20 \mathrm{E}-05$ & $7.07 \mathrm{E}-06$ & $3.77 \mathrm{E}-06$ \\
\hline Acidification & (lbs $\mathrm{SO}_{2}$-eq.) & 12.74 & 17.72 & 11.47 & 13.27 \\
\hline Smog & (lbs ethene-eq.) & 1.40 & 0.90 & 1.38 & 2.91 \\
\hline Particulates & (lbs PM) & 6.17 & 7.73 & 1.68 & 1.53 \\
\hline Odor (aesthetics) & $\left(\right.$ million $\left.\mathrm{m}^{3}\right)$ & 17.81 & 10.61 & 7.91 & 12.30 \\
\hline Solid waste landfill space & $\left(\mathrm{ft}^{3}\right)$ & 8.24 & 29.25 & 6.34 & 9.25 \\
\hline $\begin{array}{l}\text { Hazardous waste landfill } \\
\text { space }\end{array}$ & $\left(\mathrm{ft}^{3}\right)$ & 0.21 & 0.22 & 0.14 & 0.15 \\
\hline Eutrophication & $\begin{array}{l}\text { (lbs phosphate- } \\
\text { eq.) }\end{array}$ & 0.44 & 0.24 & 0.28 & 0.31 \\
\hline Water quality - BOD & (lbs BOD) & 1.83 & 1.03 & 0.82 & 1.40 \\
\hline Water quality - TSS & (lbs TSS) & 8.38 & 4.79 & 8.53 & 6.99 \\
\hline
\end{tabular}

Notes: Bold indicates lowest impacts.

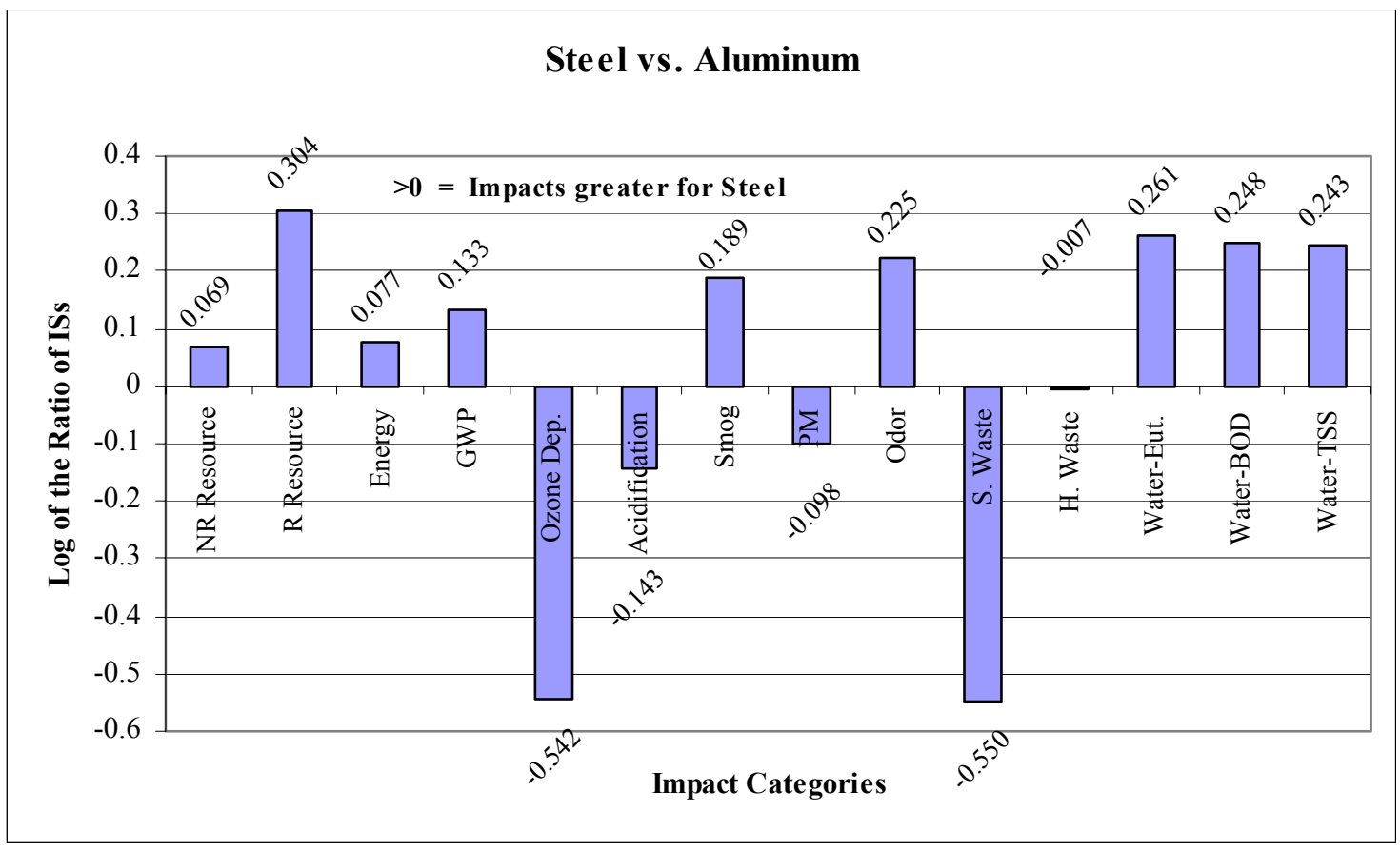

Figure 3.4. Exterior Body Panels - Steel vs. Aluminum Comparison 
A comparative chart depicting all impact categories for steel vs. aluminum is presented in Figure 3.4. Each bar indicates the extent to which the impact score associated with a particular profile is greater or less than that of the profile it is being compared with, for example, the GWP of steel is 1.36 times that of aluminum. However, this ratio has not been presented as is, but normalized by taking its log value (which is 0.133 in the case of GWP), which moves the equivalent point from 1 to 0 (creates a baseline of " 0 "). Log values greater than zero show up as bars above the " 0 " line, indicating that one particular alternative (in this case steel) has greater impact. On the other hand, log values less than zero show up as bars below the " 0 " line, indicating that the other alternative (in this case aluminum) has greater impact. While this chart indicates the magnitude of the differences in impact scores within each category, it does not show how significant or insignificant the numbers themselves are. For example, though the ozone depletion bar shows up as a huge negative value, the actual numbers (in lbs of CFC11 equivalents) are quite small (see Table 3.2).

In its comparison with CFRP (Figure 3.5), steel turns out to be worse in all impact categories except water quality (total suspended solids). The difference in the scores is the most striking in the particulates impact category.

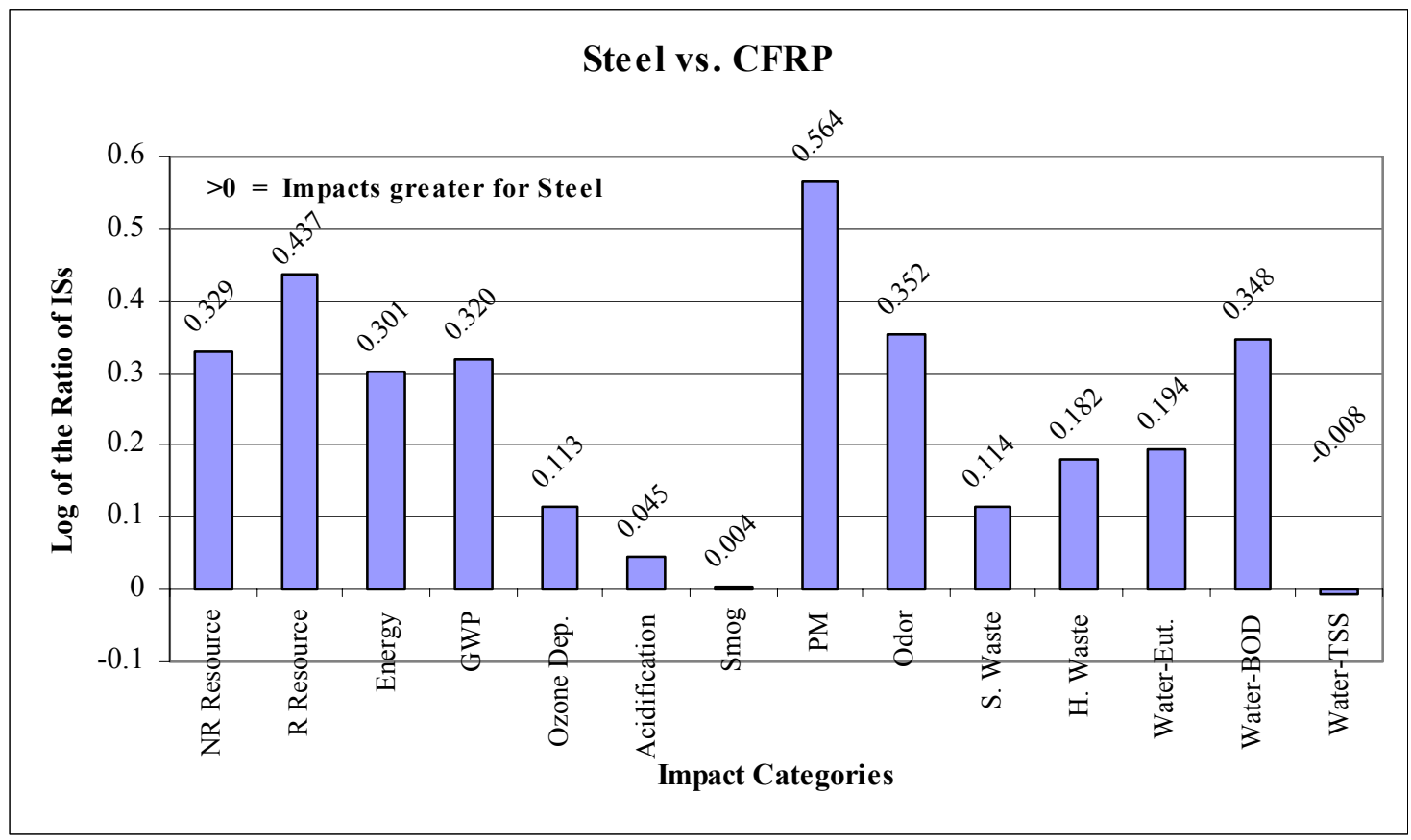

Figure 3.5. Exterior Body Panels - Steel vs. CFRP Comparison

Steel is better than GFRP in only 3 of the 14 impact categories evaluated: smog formation, solid waste generation, and acidification (Figure 3.6). Again, the most striking difference is in the particulates impact category.

Lastly, since CFRP appears to have the lowest overall impacts, that profile's impacts are compared directly to aluminum and GFRP in Figures 3.7 and 3.8, respectively. In Figure 3.7, it can be seen that CFRP has higher impact scores in only three impact categories: smog 


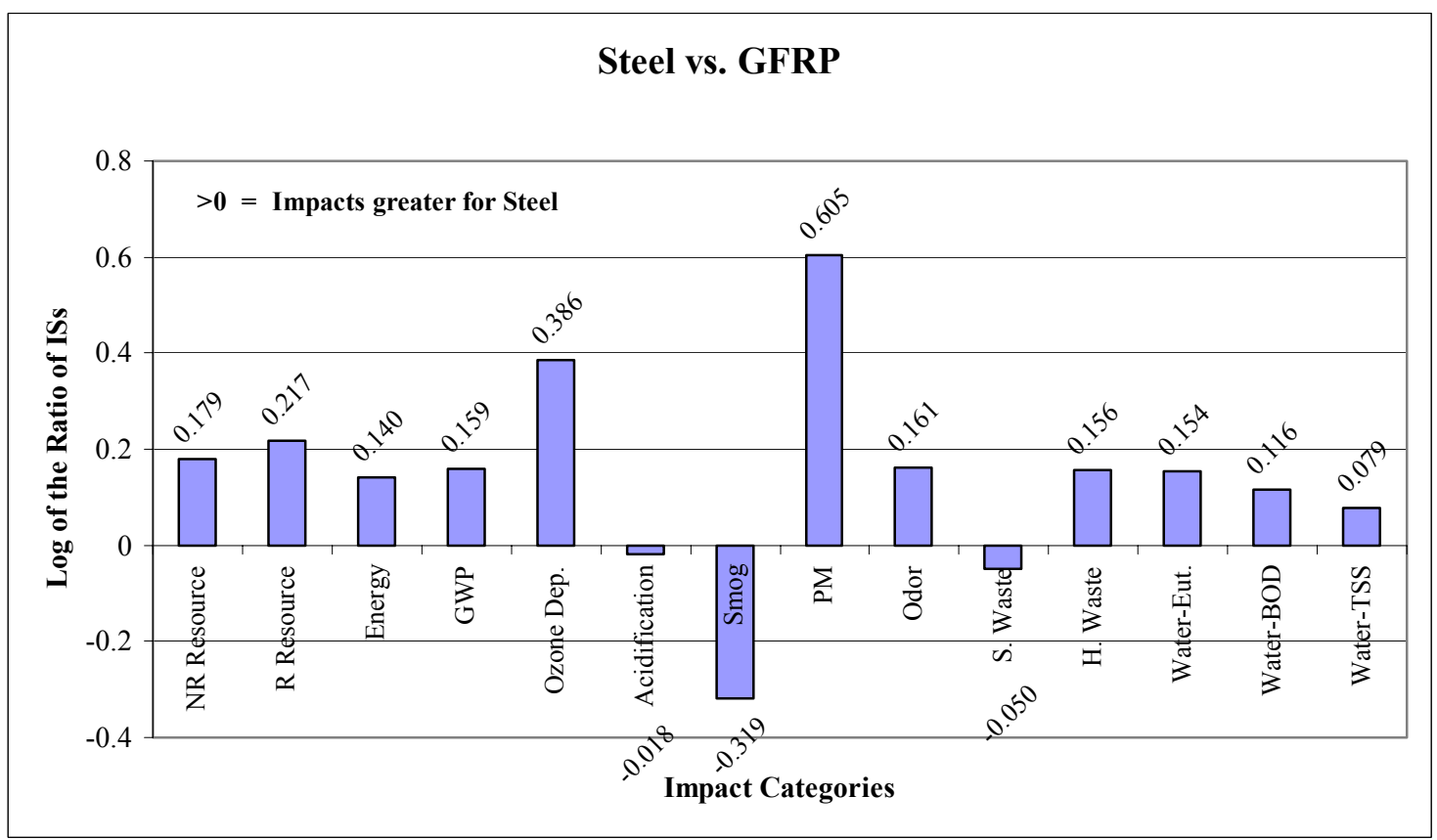

Figure 3.6. Exterior Body Panels - Steel vs. GFRP Comparison

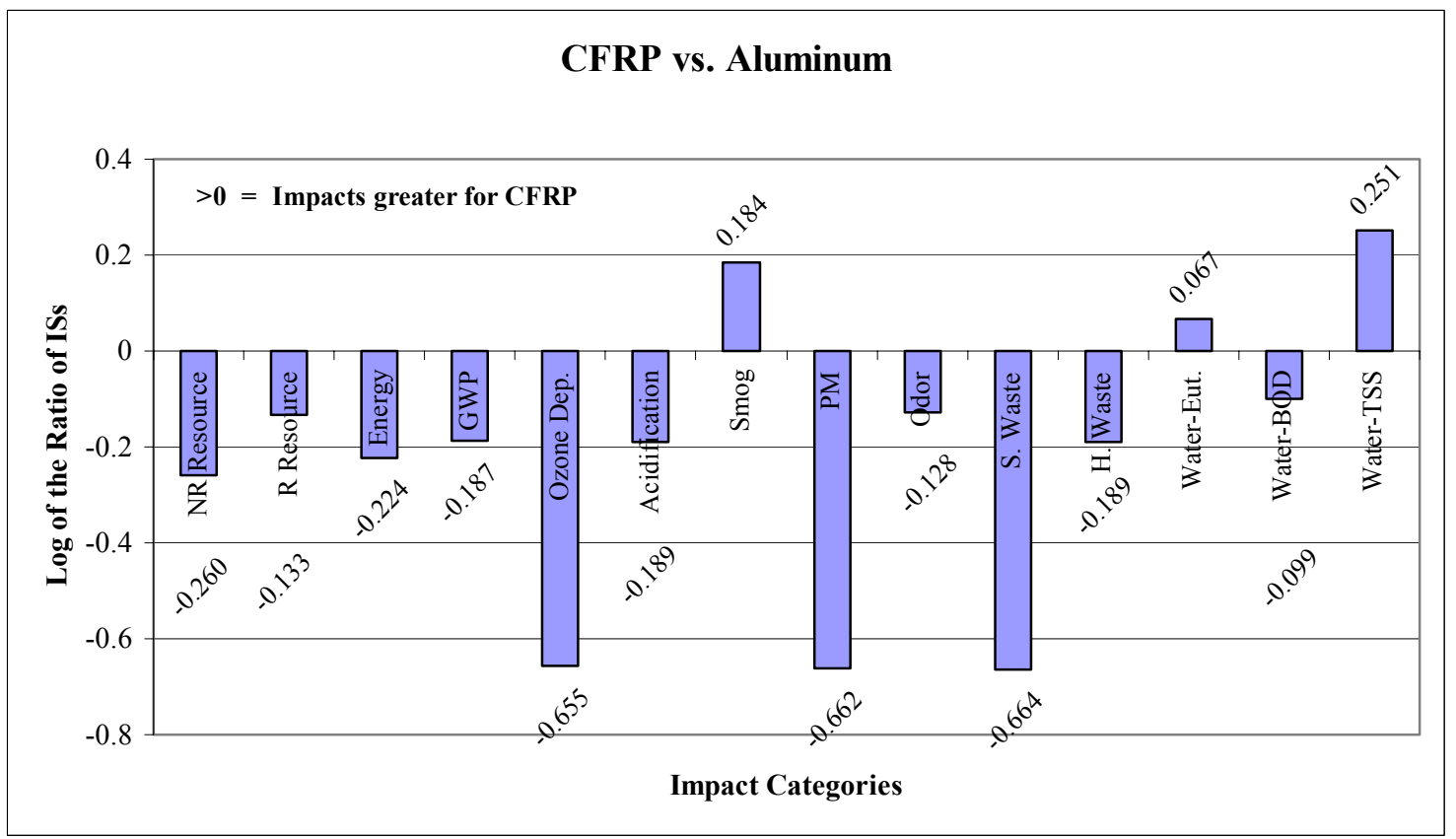

Figure 3.7. Exterior Body Panels - CFRP vs. Aluminum Comparison 


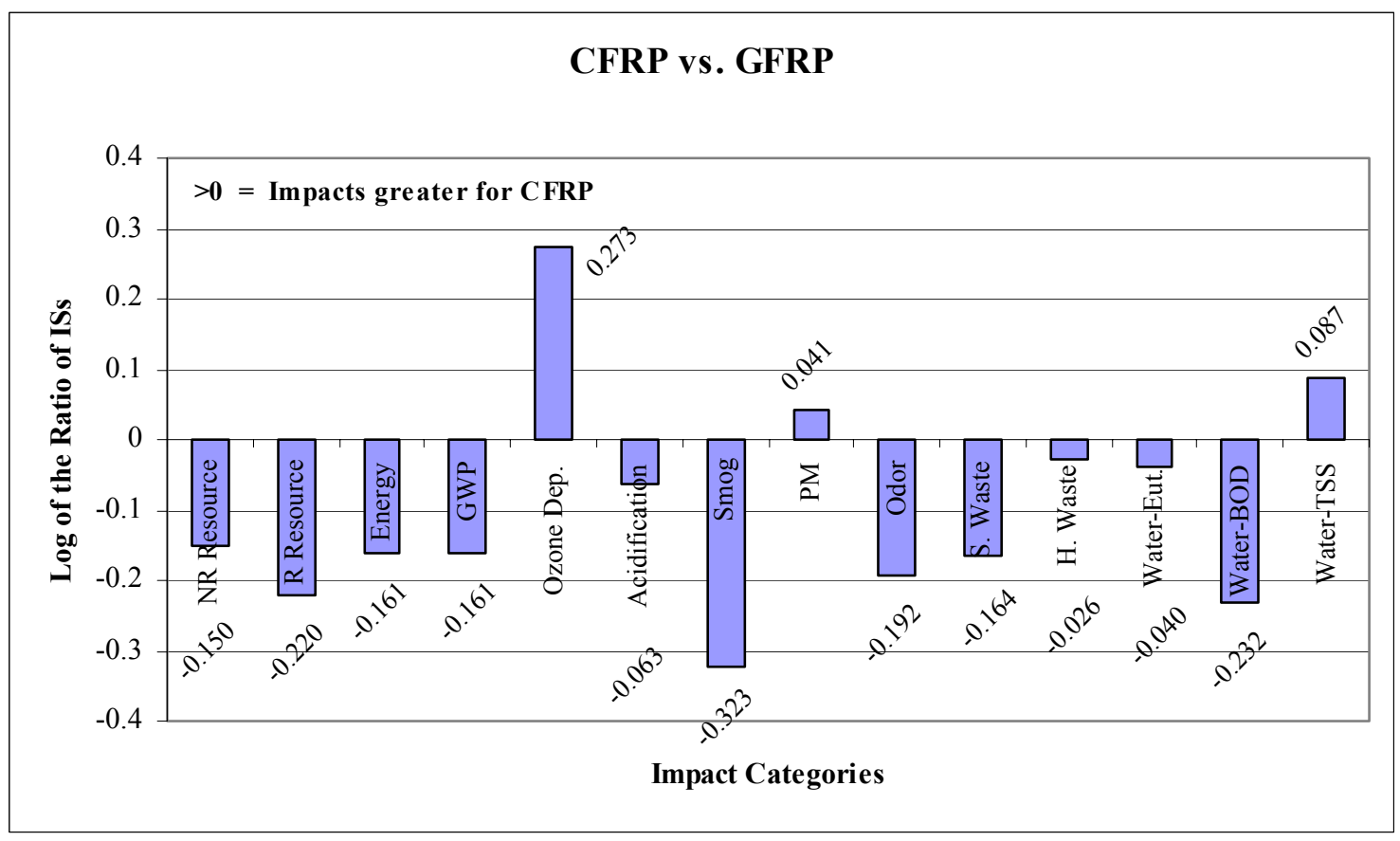

Figure 3.8. Exterior Body Panels - CFRP vs. GFRP Comparison

formation and two water quality categories, eutrophication and total suspended solids. Ozone depletion, particulates and solid waste generation are the categories with the most pronounced differences in favor of CFRP. In these three categories, aluminum's score is almost five times that of CFRP. In Figure 3.8, a very similar picture is seen with the main difference being a switch in two impact categories where CFRP now has higher scores: ozone depletion and particulates. It should also be noted that in both of these comparisons, the impact categories of nonrenewable resource use, energy use, global warming, and solid waste generation all reveal significantly lower impacts for CFRP.

Shifting focus to individual impact categories, as exhibited in Figure 3.9, CFRP has the lowest nonrenewable resource use impacts, with fuel production during Use dominating this category, and E\&MP almost completely accounting for the rest.

Table 3.3 reveals that the top contributor in each case is gasoline production, accounting for $\sim 70-84 \%$ of the total nonrenewable resource impacts for steel, CFRP, and GFRP. In the case of aluminum, gasoline production is still number one, but accounts for only about $45 \%$ of the total impacts in this category. The production of automotive wrought aluminum comes in second and third, accounting for approximately another $40 \%$ of the nonrenewable resource use impacts for aluminum. 


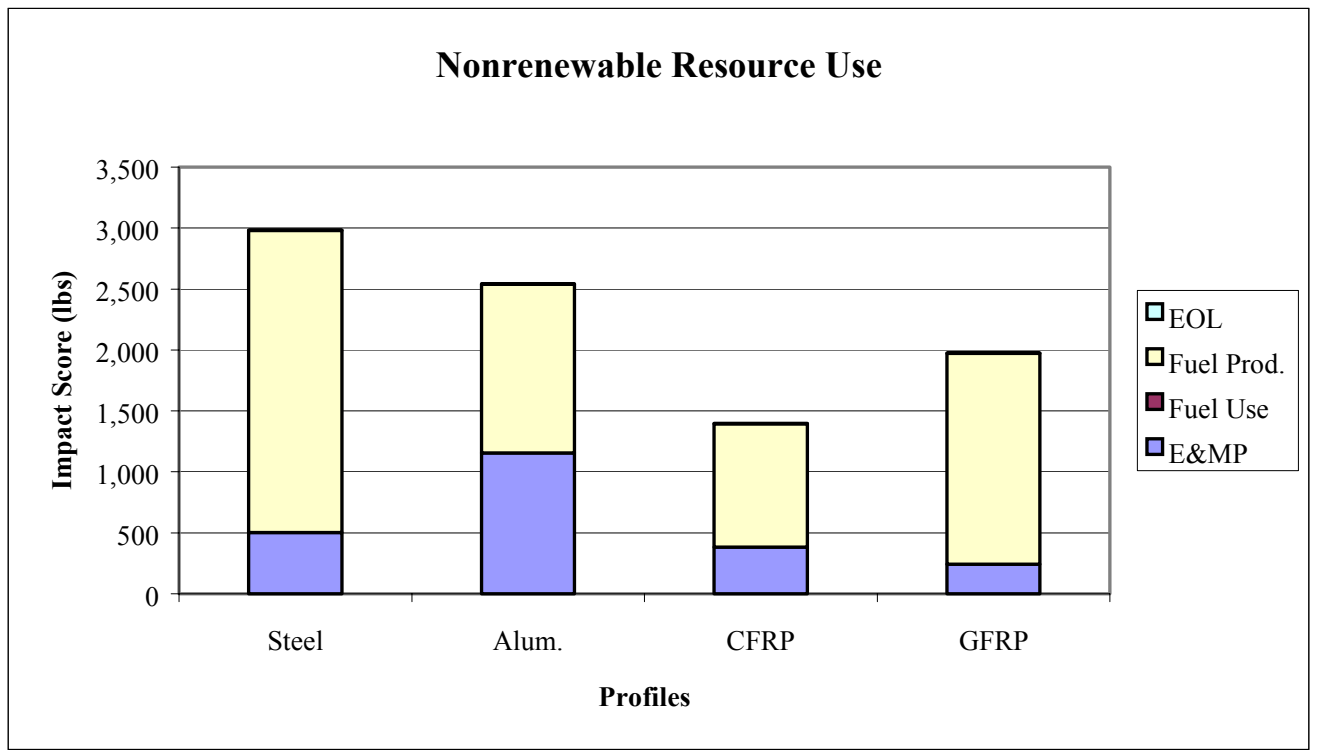

Figure 3.9. Exterior Body Panels - Nonrenewable Resource Use

Table 3.3. Nonrenewable Resource Use in the Exterior Body Panels Assessment: Lifecycle Stage Scores and Biggest Contributors

\begin{tabular}{|c|c|c|c|c|c|}
\hline $\begin{array}{l}\text { Nonrenewable } \\
\text { Resource use } \\
\text { (lbs) }\end{array}$ & E\&MP & $\begin{array}{c}\text { Use - } \\
\text { Fuel Use }\end{array}$ & $\begin{array}{c}\text { Use - } \\
\text { Fuel Prod. }\end{array}$ & $\overline{\text { EOL }}$ & Total \\
\hline Steel & 501.3 & 0 & $2,480.0$ & 1.8 & $2,983.1$ \\
\hline Aluminum & $1,154.6$ & 0 & $1,385.1$ & 2.9 & $2,542.6$ \\
\hline CFRP & 383.1 & 0 & $1,013.1$ & 0.7 & $1,396.9$ \\
\hline GFRP & 243.2 & 0 & $1,729.4$ & 1.3 & $1,973.9$ \\
\hline $\begin{array}{l}\text { Biggest } \\
\text { Contributors }\end{array}$ & $\begin{array}{c}\text { Life-cycle } \\
\text { Stage }\end{array}$ & Process & Input & $\begin{array}{c}\text { Score } \\
(\mathrm{lbs})\end{array}$ & $\begin{array}{l}\text { Percent } \\
\text { of Total }\end{array}$ \\
\hline $\begin{array}{l}\text { Steel }-1 \\
\text { Steel }-2 \\
\text { Steel }-3\end{array}$ & $\begin{array}{l}\text { Use } \\
\text { Use } \\
\text { E\&MP }\end{array}$ & $\begin{array}{l}\text { Gasoline Prod. } \\
\text { Gasoline Prod. } \\
\text { Steel Prod. }\end{array}$ & $\begin{array}{l}\text { Petroleum } \\
\text { Natural gas } \\
\text { Iron ore }\end{array}$ & $\begin{array}{r}2,032.6 \\
355.2 \\
274.8\end{array}$ & $\begin{array}{r}68.1 \% \\
11.9 \% \\
9.2 \%\end{array}$ \\
\hline $\begin{array}{l}\text { Aluminum - } 1 \\
\text { Aluminum - } 2 \\
\text { Aluminum - } 3\end{array}$ & $\begin{array}{l}\text { Use } \\
\text { E\&MP } \\
\text { E\&MP }\end{array}$ & $\begin{array}{l}\text { Gasoline Prod. } \\
\text { Auto. Wrought Alum. } \\
\text { Prod. } \\
\text { Auto. Wrought Alum. } \\
\text { Prod. }\end{array}$ & $\begin{array}{l}\text { Petroleum } \\
\text { Coal } \\
\text { Bauxite ore }\end{array}$ & $\begin{array}{r}1,135.2 \\
521.5 \\
488.9 \\
\end{array}$ & $\begin{array}{l}44.7 \% \\
20.5 \% \\
19.2 \% \\
\end{array}$ \\
\hline $\begin{array}{l}\text { CFRP }-1 \\
C F R P-2 \\
C F R P-3\end{array}$ & $\begin{array}{l}\text { Use } \\
\text { Use } \\
\text { E\&MP }\end{array}$ & $\begin{array}{l}\text { Gasoline Prod. } \\
\text { Gasoline Prod. } \\
\text { Epoxy Resin Prod. }\end{array}$ & $\begin{array}{l}\text { Petroleum } \\
\text { Natural gas } \\
\text { Natural gas } \\
\end{array}$ & $\begin{array}{l}830.4 \\
145.1 \\
104.0 \\
\end{array}$ & $\begin{array}{r}59.4 \% \\
10.4 \% \\
7.4 \% \\
\end{array}$ \\
\hline $\begin{array}{l}\text { GFRP }-1 \\
\text { GFRP }-2 \\
\text { GFRP }-3\end{array}$ & $\begin{array}{l}\text { Use } \\
\text { Use } \\
\text { E\&MP }\end{array}$ & $\begin{array}{l}\text { Gasoline Prod. } \\
\text { Gasoline Prod. } \\
\text { Glass fiber composite } \\
\text { Mfg. }\end{array}$ & $\begin{array}{l}\text { Petroleum } \\
\text { Natural gas } \\
\text { Petroleum }\end{array}$ & $\begin{array}{r}1,412.0 \\
246.7 \\
147.6\end{array}$ & $\begin{array}{r}71.8 \% \\
12.5 \% \\
7.5 \%\end{array}$ \\
\hline
\end{tabular}


The Energy Use impacts are controlled by the Use stage, which includes Fuel Production and Fuel Use (Figure 3.10). Here again, CFRP has the least overall impacts. Aluminum is fairly energy-intensive to produce, and this fact is borne out in a comparison of the E\&MP impacts of the four different materials, which shows that the energy used in the E\&MP stage is lowest for steel and highest for aluminum.

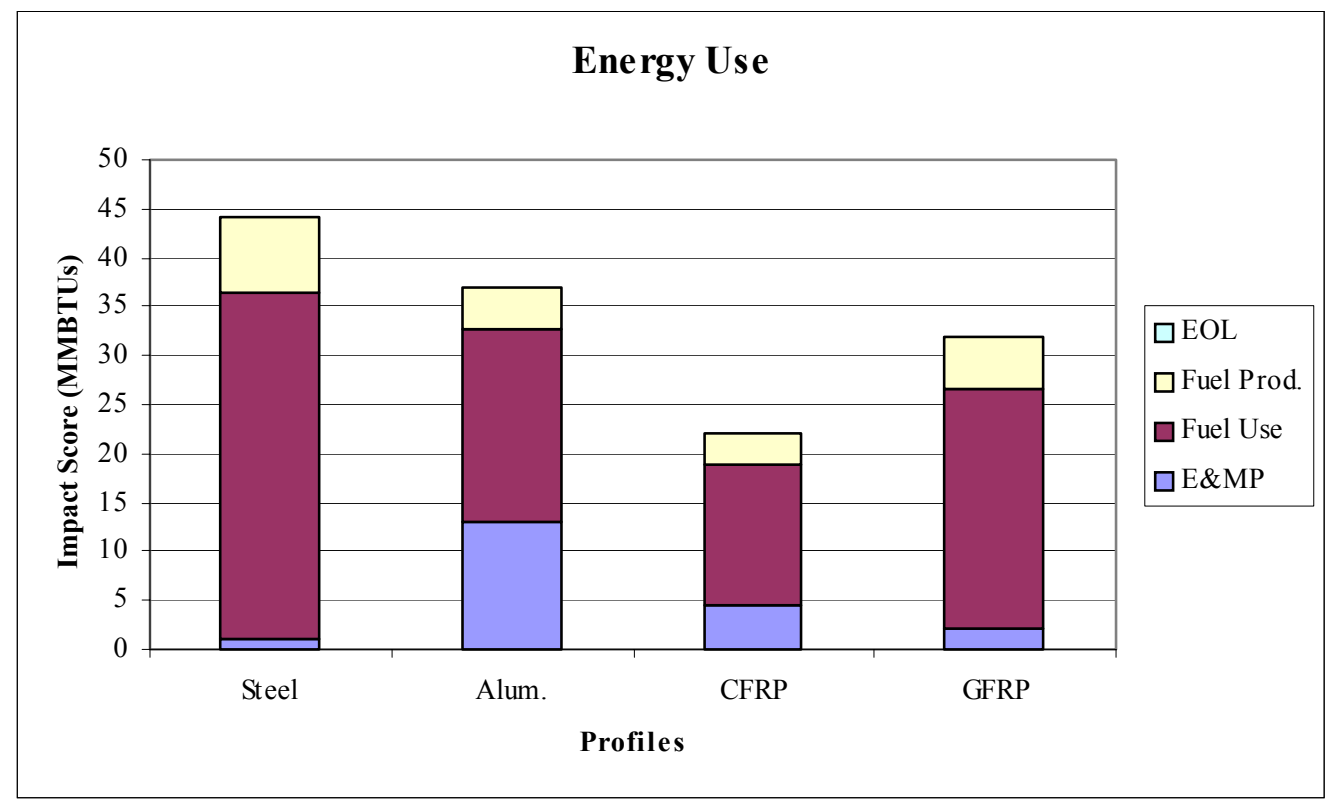

Figure 3.10. Exterior Body Panels - Energy Use

The top three contributors to the Energy Use impacts are shown in Table 3.4. Driving (fuel use) and gasoline production (fuel production) together make up about $97 \%, 78 \%$, and $92 \%$ of the energy use impacts in the case of steel, CFRP, and GFRP, respectively. In the case of aluminum, driving accounts for $53 \%$ of the energy use, while aluminum production accounts for another $31 \%$.

The GWP impacts (Figure 3.11) follow a pattern similar to energy use, except that the difference between steel and aluminum in the E\&MP stage here is not as pronounced as it is in the case of energy use. This difference occurs because there are GWP emissions in the E\&MP stage that are not related to electricity generation, which dominates the aluminum profile. 


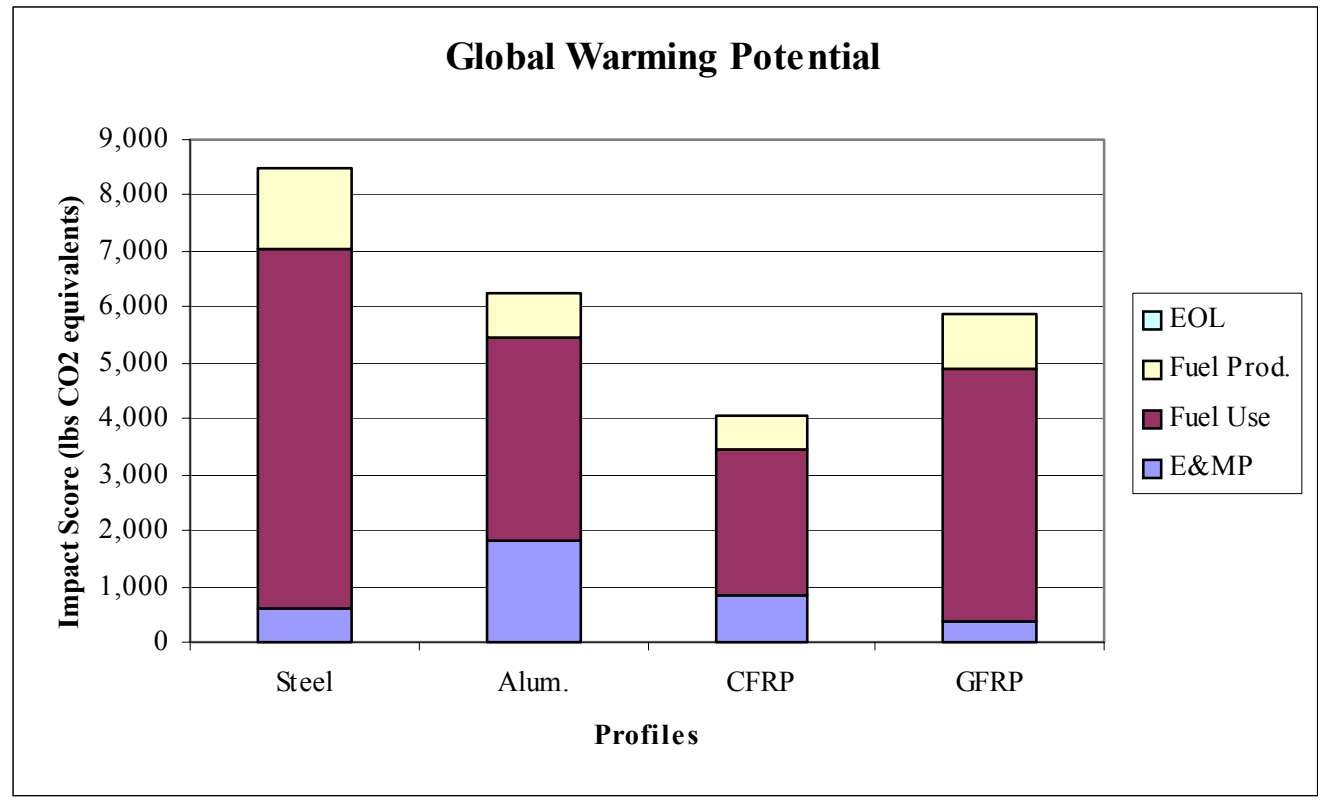

Figure 3.11. Exterior Body Panels - Global Warming Potential

\begin{tabular}{|c|c|c|c|c|c|}
\hline \multicolumn{6}{|c|}{$\begin{array}{c}\text { Table 3.4. Energy Use in the Exterior Body Panels Assessment: } \\
\text { Life-cycle Stage Scores and Biggest Contributors } \\
\end{array}$} \\
\hline $\begin{array}{l}\text { Energy Use } \\
\text { (MMBTUs) }\end{array}$ & 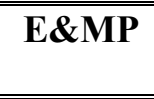 & $\begin{array}{c}\text { Use - } \\
\text { Fuel Use }\end{array}$ & $\begin{array}{c}\text { Use - } \\
\text { Fuel Prod. }\end{array}$ & $\overline{\text { EOL }}$ & Total \\
\hline Steel & 1.19 & 35.25 & 7.78 & 0.009 & 444.24 \\
\hline Aluminum & 12.97 & 19.69 & 4.35 & 0.016 & 37.02 \\
\hline CFRP & 4.53 & 14.40 & 3.18 & 0.004 & 22.11 \\
\hline GFRP & 2.00 & 24.58 & 5.43 & 0.006 & 32.02 \\
\hline $\begin{array}{l}\text { Biggest } \\
\text { Contributors }\end{array}$ & $\begin{array}{l}\text { Life- } \\
\text { cycle } \\
\text { Stage }\end{array}$ & Process & Input & $\begin{array}{c}\text { Score } \\
(\mathrm{MMBTUs})\end{array}$ & $\begin{array}{l}\text { Percent } \\
\text { of Total }\end{array}$ \\
\hline Steel - 1 & Use & Driving & Gasoline & 35.25 & $79.7 \%$ \\
\hline Steel - 2 & Use & Gasoline Prod. & Natural gas & 6.80 & $15.4 \%$ \\
\hline Steel - 3 & Use & Gasoline Prod. & Coal & 0.88 & $2.0 \%$ \\
\hline $\begin{array}{l}\text { Aluminum - } \\
1\end{array}$ & Use & Driving & Gasoline & 19.69 & $53.2 \%$ \\
\hline $\begin{array}{l}\text { Aluminum - } \\
2\end{array}$ & E\&MP & $\begin{array}{l}\text { Auto. Wrought Alum. } \\
\text { Prod. }\end{array}$ & Electricity & 6.48 & $17.5 \%$ \\
\hline $\begin{array}{l}\text { Aluminum - } \\
3\end{array}$ & E\&MP & $\begin{array}{l}\text { Auto. Wrought Alum. } \\
\text { Prod. }\end{array}$ & Coal & 5.01 & $13.5 \%$ \\
\hline CFRP - 1 & Use & Driving & Gasoline & 14.40 & $65.1 \%$ \\
\hline CFRP - 2 & Use & Gasoline Prod. & Natural gas & 2.78 & $12.6 \%$ \\
\hline CFRP - 3 & E\&MP & Epoxy Resin Prod. & Natural gas & 1.47 & $6.7 \%$ \\
\hline GFRP -1 & Use & Driving & Gasoline & 24.58 & $76.8 \%$ \\
\hline GFRP - 2 & Use & Gasoline Prod. & Natural gas & 4.74 & $14.8 \%$ \\
\hline GFRP -3 & E\&MP & $\begin{array}{l}\text { Glass fiber composite } \\
\text { Mfg. }\end{array}$ & Natural gas & 1.01 & $3.2 \%$ \\
\hline
\end{tabular}


The major contributors to the Global Warming impacts are, again, Driving and Gasoline Production, as can be observed from Table 3.5. However, production of materials in the E\&MP stage shows up as one of the top three contributors in each case (steel, automotive wrought aluminum, epoxy resin, and glass fiber). For aluminum, material production is number two, whereas it is the number three contributor in every other case.

\begin{tabular}{|c|c|c|c|c|c|}
\hline $\begin{array}{l}\mathbf{G W P} \\
\text { (lbs } \mathrm{CO}_{2} \\
\text { equiv.) }\end{array}$ & E\&MP & $\begin{array}{c}\text { Use - } \\
\text { Fuel Use }\end{array}$ & $\begin{array}{c}\text { Use - } \\
\text { Fuel } \\
\text { Prod. }\end{array}$ & EOL & Total \\
\hline Steel & 592.75 & $6,453.89$ & $1,423.59$ & 4.29 & $8,474.52$ \\
\hline Aluminum & $1,832.19$ & $3,603.73$ & 795.09 & 5.81 & $6,236.82$ \\
\hline CFRP & 835.51 & $2,637.00$ & 581.55 & 1.72 & $4,055.77$ \\
\hline GFRP & 385.88 & $4,498.40$ & 992.72 & 2.96 & $5,879.96$ \\
\hline $\begin{array}{l}\text { Biggest } \\
\text { Contributors }\end{array}$ & $\begin{array}{l}\text { Life-cycle } \\
\text { Stage }\end{array}$ & Process & Output & $\begin{array}{c}\text { Score } \\
\text { (lbs } \mathrm{CO}_{2} \\
\text { equiv.) } \\
\end{array}$ & $\begin{array}{l}\text { Percent } \\
\text { of Total }\end{array}$ \\
\hline Steel - 1 & Use & Driving & $\mathrm{CO}_{2}$ & $6,449.00$ & $76.1 \%$ \\
\hline Steel -2 & Use & Gasoline Prod. & $\mathrm{CO}_{2}$ & $1,260.07$ & $14.9 \%$ \\
\hline Steel -3 & E\&MP & Steel Prod. & $\mathrm{CO}_{2}$ & 532.64 & $6.3 \%$ \\
\hline Aluminum - 1 & Use & Driving & $\mathrm{CO}_{2}$ & $3,601.00$ & $57.7 \%$ \\
\hline Aluminum - 2 & E\&MP & $\begin{array}{l}\text { Auto. Wrought Alum. } \\
\text { Prod. }\end{array}$ & $\mathrm{CO}_{2}$ & $1,704.13$ & $27.3 \%$ \\
\hline Aluminum - 3 & Use & Gasoline Prod. & $\mathrm{CO}_{2}$ & 703.76 & $11.3 \%$ \\
\hline CFRP - 1 & Use & Driving & $\mathrm{CO}_{2}$ & $2,635.00$ & $65.0 \%$ \\
\hline CFRP - 2 & Use & Gasoline Prod. & $\mathrm{CO}_{2}$ & 514.75 & $12.7 \%$ \\
\hline $\mathrm{CFRP}-3$ & E\&MP & Epoxy Resin Prod. & $\mathrm{CO}_{2}$ & 364.74 & $9.0 \%$ \\
\hline GFRP - 1 & Use & Driving & $\mathrm{CO}_{2}$ & $4,495.00$ & $76.4 \%$ \\
\hline GFRP - 2 & Use & Gasoline Prod. & $\mathrm{CO}_{2}$ & 878.70 & $14.9 \%$ \\
\hline GFRP -3 & E\&MP & $\begin{array}{l}\text { Glass fiber composite } \\
\text { Mfg. }\end{array}$ & $\mathrm{CO}_{2}$ & 375.93 & $6.4 \%$ \\
\hline
\end{tabular}

There are two noteworthy points regarding the solid waste landfill space category, as seen in Figure 3.12. First, aluminum has a huge amount of solid waste associated with its production (primarily slag and ash), which shows up in the E\&MP stage. Second, the EOL stage becomes significant for both CFRP and GFRP because these materials are assumed to be landfilled, after going through the shredding process.

In the Solid Waste category, the major impacts for the two composite materials, CFRP and GFRP, are from landfilling them as part of ASR at the EOL stage. Table 3.6 shows that gasoline production leads other contributors of solid waste for steel, and is the second largest waste generator for both of the composite materials. In the case of aluminum, two wastes from aluminum production account for over $87 \%$ of the impacts, with gasoline production waste accounting for only $7 \%$. 


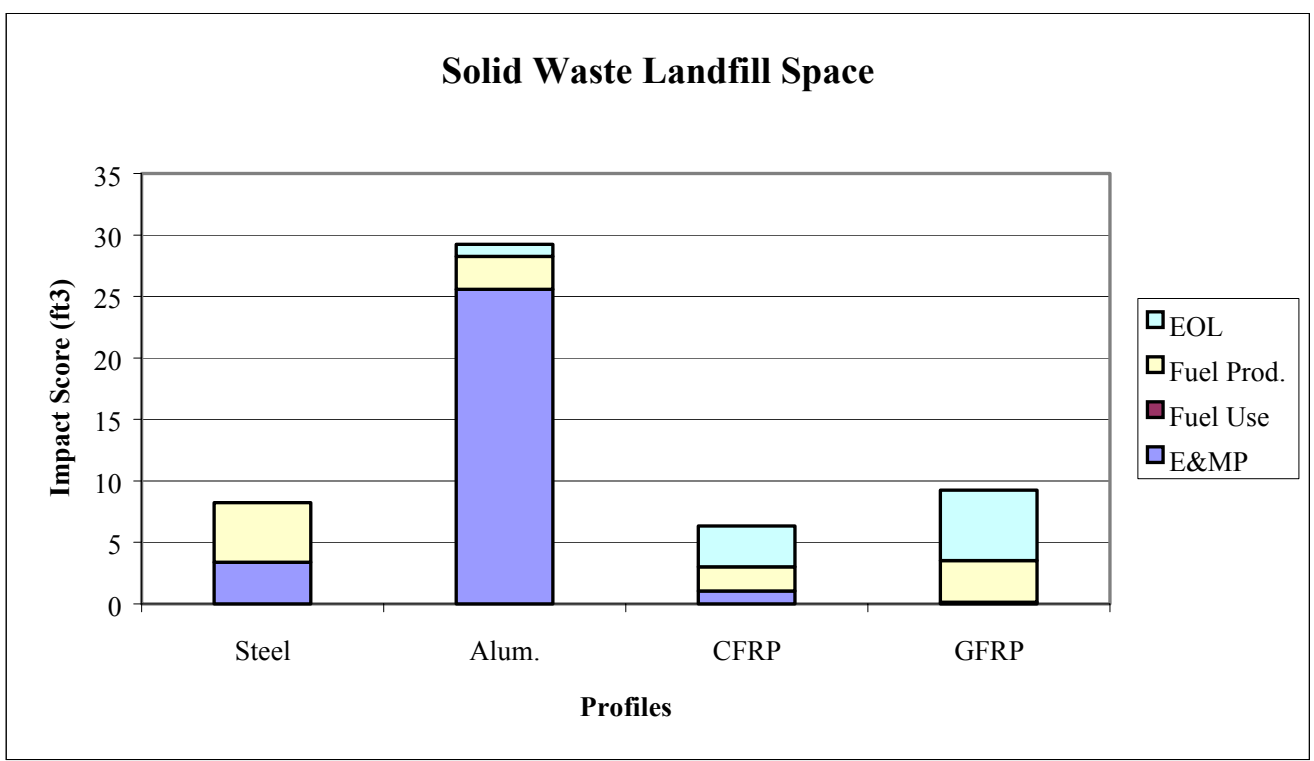

Figure 3.12. Exterior Body Panels - Solid Waste Landfill Space

\begin{tabular}{|l|r|l|l|r|r|}
\hline \multicolumn{7}{|c|}{ Table 3.6. Solid Waste Landfill Space in the Exterior Body Panels Assessment: Life- } \\
cycle Stage Scores and Biggest Contributors
\end{tabular}




\subsubsection{Monocoque Analysis Results}

As mentioned earlier in the assumptions for this analysis in Section 3.3.7, the quantity of steel assumed to be replaced is 1,077 lbs. The mass of the CFRP monocoque that replaces the steel is $190.5 \mathrm{~kg}$, or about $420 \mathrm{lbs}$. The likely composition of the CFRP composite for the monocoque includes a CFRP skin with a PVC core (Williams, 2001), as indicated in Table 3.7 .

\begin{tabular}{|l|l|r|r|}
\hline \multicolumn{3}{|c|}{ Table 3.7. Profiles Evaluated for the Monocoque Analysis } \\
\hline \hline \multirow{3}{*}{ Assessment Data } & & \multicolumn{2}{c|}{ Profiles } \\
\cline { 3 - 4 } & & \multicolumn{1}{c|}{$\begin{array}{c}\text { CFRP } \\
\text { Sonocoque }\end{array}$} \\
\hline \hline Mass of BIW+panels / monocoque & Units & 1,077 & 420 \\
\hline Material information: & $(\mathrm{lbs})$ & \multicolumn{3}{|}{} \\
\hline 1) Steel = 100\% cold-rolled BOF steel & $(\mathrm{lbs})$ & 3,248 & 2,263 \\
\hline 2) Monocoque = 30\% PVC,49\% carbon fiber, 21\% epoxy resin (by mass) \\
\hline Mass of vehicle & $(\mathrm{lbs})$ & 9,206 & 4,251 \\
\hline Mass of fuel consumed in Use* & $(\mathrm{mpg})$ & 26.60 & 32.25 \\
\hline Vehicle fuel efficiency & --- & Recycled & ASR / landfill \\
\hline EOL disposition
\end{tabular}

* By the associated parts only (linearly scaled from entire vehicle fuel need via weight relationship).

It is observed from the impact scores presented in Table 3.8 (and in Figure 3.13) that steel, which had the highest scores in nearly every impact category in all the profiles analyzed in the original assessment, now becomes environmentally preferable in three impact categories ozone depletion, acidification, and smog formation. In all other categories, CFRP still has the lowest scores. Although the difference is minimal in the cases of ozone depletion and acidification, the turnaround from the original results shows that certain environmental impacts might become significant when larger quantities of carbon fiber-based composites are used, as in this case.

In burrowing down into the carbon fiber production data and impacts, the following is found. Approximately $75 \%$ of the ozone depletion impacts for the CFRP monocoque are from electricity generation for carbon fiber production. For acidification, approximately $15 \%$ of the impacts are from the release of ammonia and NOx during carbon fiber production, which is the second largest contributor after gasoline production $(\sim 30 \%)$. In smog formation, about $37 \%$ of the impacts come from the release of unspeciated NMHCs from carbon fiber production, with another $\sim 13 \%$ coming from the generation of unspeciated hydrocarbons from acrylonitrile production (a precursor to carbon fiber). 


\begin{tabular}{|c|c|c|c|}
\hline \multicolumn{4}{|c|}{ Table 3.8. Impact Scores for the Monocoque Analysis } \\
\hline \multirow[t]{2}{*}{ Impact Category } & \multirow[t]{2}{*}{ Units } & \multicolumn{2}{|c|}{ Profiles } \\
\hline & & Steel & $\begin{array}{r}\text { CFRP } \\
\text { Monocoque }\end{array}$ \\
\hline \multicolumn{4}{|l|}{ Impacts from Inputs } \\
\hline Nonrenewable resource use & (lbs) & $14,582.96$ & $7,7,606.21$ \\
\hline Renewable resource use & (lbs) & $590,299.50$ & $243,950.42$ \\
\hline Energy use & (MMBTUs) & 216.57 & 116.48 \\
\hline \multicolumn{4}{|l|}{ Impacts from Outputs } \\
\hline Global Warming & (lbs $\mathrm{CO}_{2}$-eq.) & "41,486.64 & 21,932.45 \\
\hline Ozone Depletion & (lbs CFC11-eq.) & $4.49 E-05$ & $5.01 \mathrm{E}-05$ \\
\hline Acidification & (lbs $\mathrm{SO}_{2}$-eq.) & 62.35 & 65.27 \\
\hline Smog & (lbs ethene-eq.) & 6.84 & 9.58 \\
\hline Particulates & (lbs PM) & 30.21 & 6.12 \\
\hline Odor (aesthetics) & $\left(\right.$ million $\left.\mathrm{m}^{3}\right)$ & 87.19 & 44.15 \\
\hline Solid waste landfill space & $\left(\mathrm{ft}^{3}\right)$ & 40.34 & 33.40 \\
\hline $\begin{array}{l}\text { Hazardous waste landfill } \\
\text { space }\end{array}$ & $\left(\mathrm{ft}^{3}\right)$ & 1.04 & 0.64 \\
\hline Eutrophication & $\begin{array}{l}\text { (lbs phosphate- } \\
\text { eq.) }\end{array}$ & 2.15 & 1.35 \\
\hline Water quality - BOD & (lbs BOD) & 8.97 & 4.27 \\
\hline Water quality - TSS & (lbs TSS) & 41.03 & 26.59 \\
\hline
\end{tabular}

Notes: Bold indicates lowest impacts.

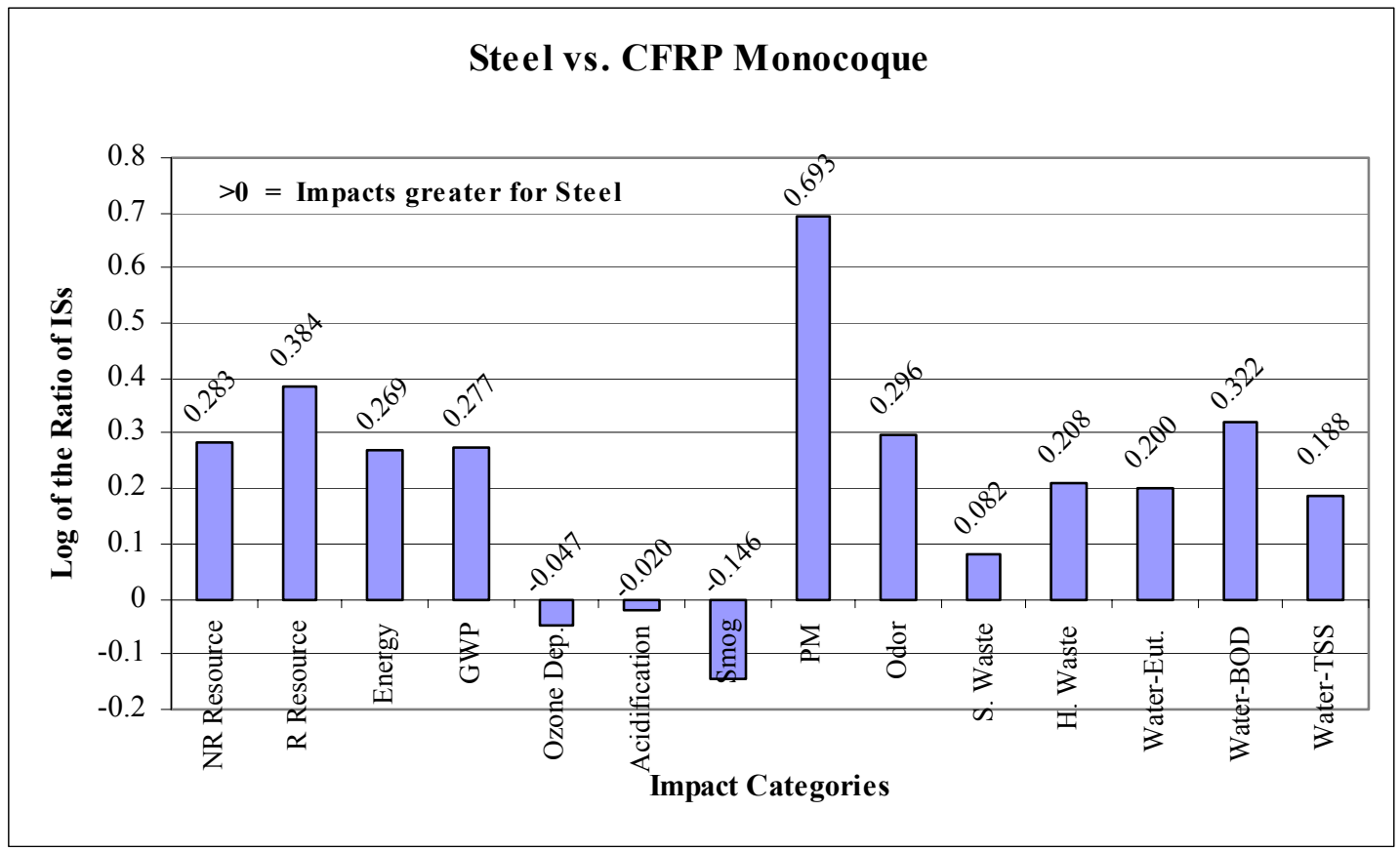

Figure 3.13. Steel vs. CFRP Monocoque Comparison 


\subsection{HYBRID ELECTRIC VEHICLE BATTERY ASSESSMENT}

\subsubsection{Background and Scope}

This study involved a comparative assessment of the potential life-cycle environmental impacts of lithium-ion (LiIon) and nickel-metal hydride (NiMH) batteries for use in hybrid electric vehicles (HEVs). The focus of the baseline analyses was on current technology for the two battery types, while the long-term (LT) analyses compared the same batteries, assuming that they both would meet PNGV targets for life span and overall weight.

Lead-acid $(\mathrm{PbA})$ batteries have traditionally been used in automobiles for starting, lighting and ignition (SLI), and were the initial choice for use as a power source for electric vehicles when they were first introduced. However, due to several issues, the present-day $\mathrm{PbA}$ battery does not appear to be the best choice for use in electric vehicles (EVs) or HEVs. PbA batteries were initially included in this assessment as a competing technology, but were subsequently dropped from consideration due to their low commercialization potential arising from the battery's heavy weight, limited driving range, low specific power, and the toxicity of lead.

HEVs and lightweight materials were among the four key technologies the PNGV identified in January 1998 as focus areas for further research and development efforts. In addition, HEVs are seen by some to be the technology of choice for cars and light trucks of the future (Wormald 2000). Batteries for HEVs have to be designed to provide high bursts of energy for short durations, unlike EV batteries that need only moderate levels of power for much longer periods of time. NiMH batteries are already used in HEVs available in the market today (namely, the Honda Insight and the Toyota Prius, which garnered the best fuel efficiencies as reported in the ACEEE's Green Book (DiCicco, Kliesch and Thomas 2000)), while LiIon technology holds great promise for use in HEVs in the future, as it can provide more energy and power in smaller, lighter packages (it was also the battery of choice in the Nissan Altra $\mathrm{EV}$ and in DaimlerChrysler's prototype vehicle, the ESX3). Lithium is the lightest element known that exists in a non-gaseous state, making it suitable for use in applications such as $3 \mathrm{XVs}$, where weight reductions are constantly sought.

For this environmental life-cycle evaluation, the functional and service units were defined as one battery pack used to power one HEV over a lifetime of 120,000 miles.

\subsubsection{Assessment-Specific Assumptions}

A number of assumptions, specific to this assessment have been made:

1) The HEV batteries compared in this assessment are based on the PNGV target of 25 $\mathrm{kW}$ for the pulse discharge in power-assist mode (NRC 2000). The two technologies compared are Lithium-ion (LiIon) and Nickel-Metal Hydride (NiMH).

2) For the baseline analysis, the weight of each battery was calculated using the PNGV target value of pulse discharge constant for $18 \mathrm{~s}$ ( $25 \mathrm{~kW}$ in power-assist mode), and dividing that number by the specific power value deemed by the PNGV as the "current performance" for each battery type (625 W/kg for LiIon, and $400 \mathrm{~W} / \mathrm{kg}$ for NiMH) 
(NRC 2000). This calculation results in the following battery weights: LiIon $\rightarrow 40 \mathrm{~kg}$; $\mathrm{NiMH} \rightarrow 62.5 \mathrm{~kg}$. Thus, in spite of their power differences, the two batteries were equated in terms of performance by considering different weights. For the long-term analysis, both batteries were assumed to weigh $40 \mathrm{~kg}$. (In fact, the Toyota Prius HEVs are soon expected to be equipped with $40 \mathrm{~kg} \mathrm{NiMH}$ batteries (NRC 2000).

3) The materials breakdown by mass percent was first obtained for each battery type, and multiplied by calculated total weights for each battery to produce a battery-specific materials breakdown.

4) The percentage breakdowns for the two batteries were obtained from two different documents produced by Argonne National Laboratory (ANL). The breakdown obtained for the LiIon battery was for a cell (ANL 2000); the breakdown obtained for the NiMH battery was for an entire battery (ANL 1998). Thus, the remaining materials for the LiIon battery (calculated to be $\sim 13 \%$ ) had to be assumed, and the percentage breakdown adjusted to include these other materials.

5) It was not clearly defined whether the breakdowns included or excluded the final packaging materials that would be needed to place the battery into the vehicle (e.g., battery tray, electronic components needed to connect the battery to the vehicle). Thus, they were excluded from the analysis.

6) With regard to the PNGV goal for battery life of 10 years, the "current performance" as defined by PNGV for each battery type was 3 years and 5 years for LiIon and NiMH HEV batteries, respectively (NRC 2000). To produce an equivalent functional unit in the baseline analysis and relate these batteries to the PNGV goal of 10 years, the data in the E\&MP life-cycle stages for LiIon and NiMH batteries was multiplied by 3.33 and 2 , respectively, to bring the current performance values up to the 10 year goal. In the long-term analysis, both batteries were assumed to have a lifespan of 10 years.

7) To produce an equivalent service unit of 120,000 miles, a fuel efficiency of 80 miles per gallon (mpg) was assumed for the LiIon battery-powered HEV, and then an "adjusted" fuel efficiency was calculated for the NiMH-powered HEV based on the weight difference of the two vehicles. The efficiency calculated for the NiMH HEV was $78.91 \mathrm{mpg}$. These values were used to calculate the amount of fuel required by the entire HEV and, subsequently, only the batteries in the Use life-cycle stage. The scaling was done using the ratio of the mass of the battery to the total HEV mass.

8) The vehicle emissions values used in the analysis came from Tier 2, Bin 2 based on PNGV targets (except for the CO value, which is quite high in the Tier 2 standards) (EPA 2000, Diselnet 2001, Wilson, Mullen and Laich 2000). ${ }^{\mathrm{i}}$ The CO value was taken from the California SULEV standards. The SULEV standards for non-methane organic gases (NMOG), NOx and PM, incidentally, are identical to Bin 2 of Tier 2, with only the $\mathrm{CO}$ emissions being different. Values for $\mathrm{CO}_{2}($ Unnasch 2000$)$ and $\mathrm{CH}_{4}$ were calculated from information provided by other sources.

9) In the EOL stage, $100 \%$ materials recycling was assumed for both battery types, due to the fact that several recycling facilities already exist for both LiIon and NiMH batteries.

\footnotetext{
${ }^{i}$ Bin 2 of the Tier 2 standards was chosen because it is the most stringent of Tier 2 (except for Bin 1 which is the zero emissions category) and is therefore best applicable to reformer-based fuel cell vehicles.
} 


\subsubsection{Lilon Assumptions}

The following assumptions, specific to the lithium ion battery, have been made:

1) From the materials percentage breakdown obtained from the ANL report on LiIon battery costs (ANL 2000), several assumptions had to be made about the further breakdown of those major materials into specific materials (e.g., a mass percent was given for the separators, and an assumption was made that the separator is made of $50 \%$ polypropylene and $50 \%$ polyethylene). The assumption that $\mathrm{LiMn}_{2} \mathrm{O}_{4}$ is the cathode active material was another such assumption. This entry was broken down into lithium and manganese on a molar weight basis.

2) The electrolyte's solvents were assumed to be constituted of ethylene carbonate (EC) and diethylene carbonate (DEC), out of choices ranging from mixes of up to six different solvents. This was based on data reviewed which stated that these solvents could be mixed to produce a usable electrolyte solvent for graphitic anodes (the material used for the anode in this analysis). Furthermore, since no LCI data on the production of either of these solvents were available, data on the two chemicals (ethylene oxide and carbon dioxide) that are used to produce EC were used. A 50/50 mix of these two chemicals was used to comprise the entire mass for the solvent.

3) A final percentage was calculated that was defined as the "rest of the battery" $(13 \%)$. It was assumed that this consists of control circuitry, module packaging and the battery case. The total percentage for this listing was split evenly into 3 values of $4.33 \%$ each. Furthermore, the control circuitry percent was assumed to consist of circuit boards and wiring, with the further assumption of 50 mass $\%$ circuit boards and 50 mass\% wiring. Lastly, the wiring was assumed to consist of PVC and copper, with the copper accounting for $85 \%$ of the mass of the wiring, leaving $15 \%$ for the PVC sheath/coating.

4) In some cases, where data on certain materials in the breakdown were not available, other materials were picked as surrogates, or that material was left out. One example is the lithium in the active material - magnesium was used as its surrogate; another example is the carbon in the cathode - graphite was used as its surrogate. Another example was the binder polyvinylidene fluoride (PVDF), which was a small amount ( $\sim .3 \%$ of the battery mass) and was thus left out of the analysis. The final percentage of the total battery mass accounted for was $89.6 \%$.

Table 3.9 shows the materials breakdown for the LiIon (and LiIon-LT) HEV battery profiles, and Figure 3.14 shows the LiIon profile as it was built in the Toolkit. In Table 3.9, the "Original" mass breakdown details the information as it was obtained; the "Final" mass breakdown allowed for the inclusion of the manganese and lithium (used magnesium as lithium's surrogate) in the cathode active material; and the last two columns show information on the materials that were included in the analysis. 


\begin{tabular}{|c|c|c|c|c|c|c|}
\hline \multicolumn{7}{|c|}{ Table 3.9. Materials Breakdown for the LiIon and LiIon-LT HEV Batteries } \\
\hline \multirow[t]{3}{*}{ Component } & \multirow[t]{3}{*}{ Material } & \multicolumn{2}{|c|}{ Mass Breakdown } & \multicolumn{3}{|c|}{ Included in Analysis? } \\
\hline & & \multirow{2}{*}{$\begin{array}{l}\text { Original } \\
(\mathrm{kg})\end{array}$} & \multirow{2}{*}{$\begin{array}{l}\text { Final } \\
(\mathrm{kg})\end{array}$} & \multirow{2}{*}{$\begin{array}{l}\mathrm{x}= \\
\text { yes }\end{array}$} & \multirow{2}{*}{$\begin{array}{l}\text { Mass } \\
(\mathrm{kg}) \\
\end{array}$} & \multirow{2}{*}{$\begin{array}{l}\text { Mass } \\
\% \\
\%) \\
\end{array}$} \\
\hline & & & & & & \\
\hline \multicolumn{7}{|l|}{ Anode } \\
\hline Electrode & Graphite & 1.347 & 1.347 & $\mathrm{x}$ & 1.347 & $3.37 \%$ \\
\hline Binder & PVDF & 0.075 & 0.075 & & & \\
\hline Carbon black & & 0.037 & 0.037 & $\mathrm{x}$ & 0.037 & $0.09 \%$ \\
\hline NMP & & 0.037 & 0.037 & & & \\
\hline Current collector & Copper & 4.454 & 4.454 & $\mathrm{x}$ & 4.454 & $11.14 \%$ \\
\hline \multicolumn{7}{|l|}{ Cathode } \\
\hline \multirow[t]{2}{*}{ Active material $\left(\mathrm{LiMn}_{2} \mathrm{O}_{4}\right)$} & & 7.170 & & & & \\
\hline & Manganese & & 4.357 & $\mathrm{x}$ & 4.357 & $10.89 \%$ \\
\hline Lithium & $\begin{array}{l}\text { (using } \\
\text { magnesium) }\end{array}$ & & 0.275 & $\mathrm{x}$ & 0.275 & $0.69 \%$ \\
\hline Carbon & & 0.720 & 0.720 & $\mathrm{X}$ & 0.720 & $1.80 \%$ \\
\hline Binder & PVDF & 0.040 & 0.040 & & & \\
\hline Carbon black & & 0.020 & 0.020 & $\mathrm{x}$ & 0.020 & $0.05 \%$ \\
\hline NMP & & 0.020 & 0.020 & & & \\
\hline Current collector & Aluminum & 2.077 & 2.077 & $\mathrm{x}$ & 2.077 & $5.19 \%$ \\
\hline \multicolumn{7}{|l|}{ Electrolyte } \\
\hline Lithium salt & & 0.069 & 0.069 & & & \\
\hline \multicolumn{7}{|l|}{$\begin{array}{l}\text { Solvents (assuming EC \& } \\
\text { DEC) }\end{array}$} \\
\hline Carbon dioxide & & 2.321 & 2.321 & $\mathrm{x}$ & 2.321 & $5.80 \%$ \\
\hline Ethylene oxide & & 2.321 & 2.321 & $\mathrm{x}$ & 2.321 & $5.80 \%$ \\
\hline \multicolumn{7}{|l|}{ Rest of battery } \\
\hline $\begin{array}{l}\text { Tabs, end plates, terminal } \\
\text { assem. }\end{array}$ & Steel* & 3.448 & 3.448 & $\mathrm{x}$ & 3.448 & $8.62 \%$ \\
\hline Cell container & Aluminum & 7.506 & 7.506 & $\mathrm{x}$ & 7.506 & $18.77 \%$ \\
\hline Module packaging & PET* $^{*}$ & 1.733 & 1.733 & $\mathrm{x}$ & 1.733 & $4.33 \%$ \\
\hline Battery case & Aluminum* & 1.733 & 1.733 & $\mathrm{x}$ & 1.733 & $4.33 \%$ \\
\hline Separators & $\mathrm{PP} / \mathrm{PE}$ & & & & & \\
\hline Polypropylene & & 0.878 & 0.878 & $\mathrm{x}$ & 0.878 & $2.20 \%$ \\
\hline Polyethylene & & 0.878 & 0.878 & $\mathrm{x}$ & 0.878 & $2.20 \%$ \\
\hline \multicolumn{7}{|l|}{ Control circuitry } \\
\hline Circuit boards & & 0.867 & 0.867 & $\mathrm{x}$ & 0.867 & $2.17 \%$ \\
\hline Wiring - copper & & 0.737 & 0.737 & $\mathrm{x}$ & 0.737 & $1.84 \%$ \\
\hline Wiring - PVC & & 0.130 & 0.130 & $\mathrm{x}$ & 0.130 & $0.33 \%$ \\
\hline Other cell components & & 1.382 & 1.382 & & & \\
\hline Totals & & 40.001 & 37.464 & & 35.841 & $89.60 \%$ \\
\hline
\end{tabular}

* With little to no data on these components, analysts assumed the components to be made of the materials listed in the table. 


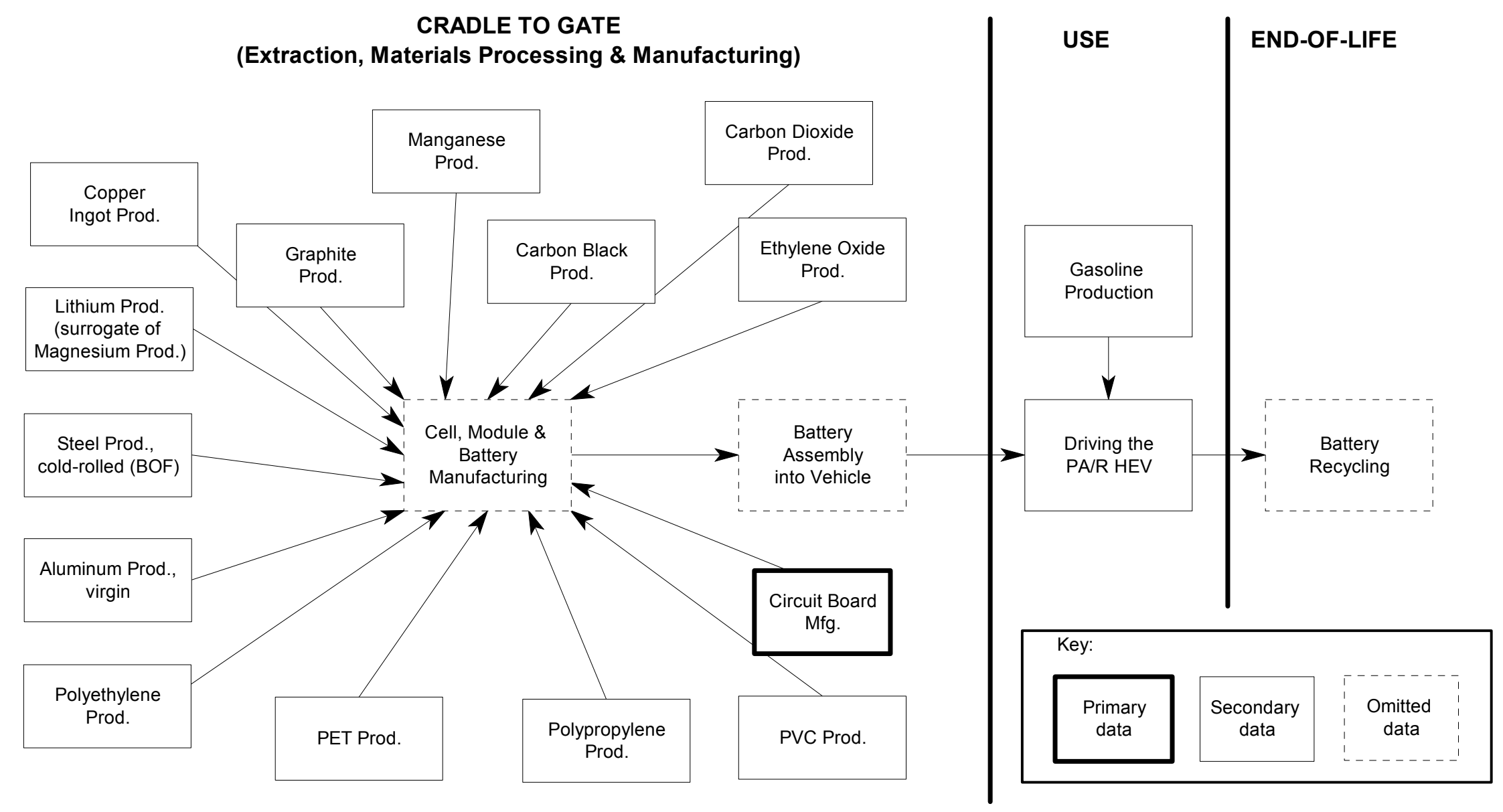

Figure 3.14. The LiIon HEV Battery Profile 


\subsubsection{NIMH Assumptions}

The following assumptions, specific to the nickel metal hydride battery, have been made:

1) From the materials percentage breakdown obtained for a NiMH battery, several assumptions had to be made about the further breakdown of those major materials into specific materials (e.g., a mass percent was given for the hydride, and a further percentage breakdown of the hydride itself was obtained from other literature).

2) The breakdown obtained from the literature listed an "other" category, which was assumed to be all wiring for electronics. This percentage was again broken down into $85 \%$ copper and $15 \%$ PVC sheathing/coating.

3) Data on one material in the breakdown (zirconium) were not available. Thus, after some review of the processes used to extract and process zirconium, titanium was used as a surrogate. The final percentage of the total battery mass accounted for was $95.52 \%$

Table 3.10 shows the materials breakdown for the NiMH HEV battery profile, Table 3.11 shows the materials breakdown for the NiMH-LT HEV battery profile, and Figure 3.15 shows the NiMH profile as it was built in the Toolkit. In Table 3.10, the "Original" mass breakdown details the information as it was obtained; the "Final" mass breakdown allowed for the inclusion of the nickel from the nickel hydroxide; and the last two columns show information on the materials that were included in the analysis. Table 3.11 shows almost the same information as Table 3.10, however the three "Mass Breakdown" columns show the NiMH breakdown, the changes made in substituting polypropylene for the stainless steel in the battery casing, and the changes made in scaling the remaining data down to $40 \mathrm{~kg}$.

\subsubsection{Long-Term Scenario}

As the LiIon HEV battery is still under development, it is quite likely that the battery actually used to power future HEVs will be different from the "current performance" battery. Moreover, the NiMH battery would also undergo changes to improve its performance for use in hybrid vehicles of the future. For this reason, it was decided to conduct additional analyses that took into account an increased lifespan for both battery types, and weight reduction opportunities that would enable both batteries to meet PNGV targets. In this long-term scenario, three different assumptions were made about the batteries, namely:

- both batteries weigh $40 \mathrm{~kg}$;

- both can achieve the PNGV goal of a 10-year life; and

- the NiMH battery has a lighter, plastic (polypropylene) casing instead of the original stainless steel. 


\begin{tabular}{|c|c|c|c|c|c|c|}
\hline \multicolumn{7}{|c|}{ Table 3.10. Materials Breakdown for the NiMH HEV Battery } \\
\hline \multirow[t]{3}{*}{ Component } & \multirow[t]{3}{*}{ Material } & \multicolumn{2}{|c|}{$\begin{array}{l}\text { Mass } \\
\text { Breakdown }\end{array}$} & \multicolumn{3}{|c|}{ Included in Analysis? } \\
\hline & & \multirow{2}{*}{\begin{tabular}{|l} 
Original \\
$(\mathrm{kg})$ \\
\end{tabular}} & \multirow{2}{*}{$\begin{array}{l}\text { Final } \\
(\mathrm{kg}) \\
\end{array}$} & \multirow{2}{*}{$\begin{array}{l}x= \\
\text { yes }\end{array}$} & \multirow{2}{*}{\begin{tabular}{|l|} 
Mass \\
$(\mathrm{kg})$ \\
\end{tabular}} & \multirow{2}{*}{$\begin{array}{l}\text { Mass \% } \\
(\%) \\
\end{array}$} \\
\hline & & & & & & \\
\hline \multicolumn{7}{|l|}{ Anode } \\
\hline \multicolumn{7}{|l|}{ Electrode - Hydride } \\
\hline Vanadium & & 1.069 & 1.069 & $\mathrm{x}$ & 1.069 & $1.71 \%$ \\
\hline Nickel & & 2.546 & 2.546 & $\mathrm{x}$ & 2.546 & $4.07 \%$ \\
\hline Zirconium & $\begin{array}{l}\text { (using } \\
\text { titanium) }\end{array}$ & 2.042 & 2.042 & $\mathrm{x}$ & 2.042 & $3.27 \%$ \\
\hline Titanium & & 1.005 & 1.005 & $\mathrm{x}$ & 1.005 & $1.61 \%$ \\
\hline Chromium & & 0.437 & 0.437 & $\mathrm{x}$ & 0.437 & $0.70 \%$ \\
\hline Cobalt & & 0.495 & 0.495 & $\mathrm{x}$ & 0.495 & $0.79 \%$ \\
\hline Iron & & 0.469 & 0.469 & $\mathrm{x}$ & 0.469 & $0.75 \%$ \\
\hline Anode substrate & Iron & 9.063 & 9.063 & $\mathrm{x}$ & 9.063 & $14.50 \%$ \\
\hline \multicolumn{7}{|l|}{ Cathode } \\
\hline \multirow[t]{2}{*}{ Electrode - Nickel hydroxide } & $\mathrm{Ni}(\mathrm{OH})_{2}$ & 7.563 & & & & \\
\hline & Nickel & & 4.764 & $\mathrm{x}$ & 4.764 & $7.62 \%$ \\
\hline Cathode substrate & Nickel & 10.250 & 10.250 & $\mathrm{x}$ & 10.250 & $16.40 \%$ \\
\hline \multicolumn{7}{|l|}{ Electrolyte } \\
\hline Potassium hydroxide (POH) & & 1.875 & 1.875 & $\mathrm{x}$ & 1.875 & $3.00 \%$ \\
\hline Water & & 3.750 & 3.750 & $\mathrm{x}$ & 3.750 & $6.00 \%$ \\
\hline \multicolumn{7}{|l|}{ Rest of battery } \\
\hline Container/casing & Stainless Steel & & & & & \\
\hline Steel, cold-rolled & & 13.956 & 13.956 & $\mathrm{x}$ & 13.956 & $22.33 \%$ \\
\hline Chromium & & 3.263 & 3.263 & $\mathrm{x}$ & 3.263 & $5.22 \%$ \\
\hline Nickel & & 0.906 & 0.906 & $\mathrm{x}$ & 0.906 & $1.45 \%$ \\
\hline Separators & Polypropylene & 3.125 & 3.125 & $\mathrm{x}$ & 3.125 & $5.00 \%$ \\
\hline \multicolumn{7}{|l|}{ Other (e.g., electronics) } \\
\hline Wiring - copper & & 0.584 & 0.584 & $\mathrm{x}$ & 0.584 & $0.94 \%$ \\
\hline Wiring - PVC & & 0.103 & 0.103 & $\mathrm{x}$ & 0.103 & $0.17 \%$ \\
\hline Totals & & 62.500 & 59.702 & & 59.702 & $95.52 \%$ \\
\hline
\end{tabular}




\begin{tabular}{|c|c|c|c|c|c|c|c|}
\hline \multicolumn{8}{|c|}{ Table 3.11. Materials Breakdown for the NiMH-LT HEV Battery } \\
\hline \multirow[t]{3}{*}{ Component } & \multirow[t]{3}{*}{ Material } & \multicolumn{3}{|c|}{ Mass Breakdown } & \multicolumn{3}{|c|}{ Included in Analysis? } \\
\hline & & \multirow{2}{*}{$\begin{array}{l}\mathrm{NiMH} \\
(\mathrm{kg})\end{array}$} & \multirow{2}{*}{$\begin{array}{l}\text { PP- } \\
\text { sub* } \\
(\mathrm{kg})\end{array}$} & \multirow{2}{*}{$\begin{array}{l}\text { Scaling^ } \\
(\mathrm{kg})\end{array}$} & \multirow{2}{*}{$\begin{array}{l}\mathrm{x}= \\
\text { yes }\end{array}$} & \multirow{2}{*}{$\begin{array}{l}\text { Mass } \\
(\mathrm{kg})\end{array}$} & \multirow{2}{*}{$\begin{array}{l}\text { Mass } \\
\% \\
(\%) * *\end{array}$} \\
\hline & & & & & & & \\
\hline \multicolumn{8}{|l|}{ Anode } \\
\hline \multicolumn{8}{|l|}{ Electrode - Hydride } \\
\hline Vanadium & & 1.069 & 1.069 & 0.921 & $\mathrm{x}$ & 0.921 & $2.30 \%$ \\
\hline Nickel & & 2.546 & 2.546 & 2.193 & $\mathrm{x}$ & 2.193 & $5.48 \%$ \\
\hline Zirconium & $\begin{array}{l}\text { (using } \\
\text { titanium) }\end{array}$ & 2.042 & 2.042 & 1.758 & $\mathrm{x}$ & 1.758 & $4.40 \%$ \\
\hline Titanium & & 1.005 & 1.005 & 0.866 & $\mathrm{x}$ & 0.866 & $2.16 \%$ \\
\hline Chromium & & 0.437 & 0.437 & 0.376 & $\mathrm{x}$ & 0.376 & $0.94 \%$ \\
\hline Cobalt & & 0.495 & 0.495 & 0.426 & $\mathrm{x}$ & 0.426 & $1.06 \%$ \\
\hline Iron & & 0.469 & 0.469 & 0.404 & $\mathrm{x}$ & 0.404 & $1.01 \%$ \\
\hline Anode substrate & Iron & 9.063 & 9.063 & 7.804 & $\mathrm{x}$ & 7.804 & $19.51 \%$ \\
\hline \multicolumn{8}{|l|}{ Cathode } \\
\hline \multirow[t]{2}{*}{$\begin{array}{l}\text { Electrode - Nickel } \\
\text { hydroxide }\end{array}$} & $\mathrm{Ni}(\mathrm{OH})_{2}$ & 7.563 & 7.563 & & & & \\
\hline & Nickel & $(4.764)$ & $(4.764)$ & 4.103 & $\mathrm{x}$ & 4.103 & $10.26 \%$ \\
\hline Cathode substrate & Nickel & 10.250 & 10.250 & 8.826 & $\mathrm{x}$ & 8.826 & $22.07 \%$ \\
\hline \multicolumn{8}{|l|}{ Electrolyte } \\
\hline $\begin{array}{l}\text { Potassium hydroxide } \\
(\mathrm{POH})\end{array}$ & & 1.875 & 1.875 & 1.615 & $\mathrm{x}$ & 1.615 & $4.04 \%$ \\
\hline Water & & 3.750 & 3.750 & 3.229 & $\mathrm{x}$ & 3.229 & $8.07 \%$ \\
\hline \multicolumn{8}{|l|}{ Rest of battery } \\
\hline Container/casing & $\mathrm{SS} \rightarrow \mathrm{PP} *$ & 18.125 & 2.076 & 1.788 & $\mathrm{x}$ & 1.788 & $4.47 \%$ \\
\hline Separators & PP & 3.125 & 3.125 & 2.691 & $\mathrm{x}$ & 2.691 & $6.73 \%$ \\
\hline \multicolumn{8}{|l|}{ Other (e.g., electronics) } \\
\hline Wiring - copper & & 0.584 & 0.584 & 0.503 & $\mathrm{x}$ & 0.503 & $1.26 \%$ \\
\hline Wiring - PVC & & 0.103 & 0.103 & 0.089 & $\mathrm{x}$ & 0.089 & $0.22 \%$ \\
\hline Totals & & 62.500 & 46.451 & 37.590 & & 37.590 & $93.98 \%$ \\
\hline
\end{tabular}

* Stainless steel was used as the battery casing material in the NiMH profile, and was changed to polypropylene for the NiMH-LT profile.

^ Scaling to a total of $40 \mathrm{~kg}$, including all the nickel hydroxide. The total is not $40 \mathrm{~kg}$ due to the inclusion of only the nickel part of the nickel hydroxide (the difference between those two plus the shown total equals $40 \mathrm{~kg}$ ).

** All percentages calculated as the component's included mass divided by a total mass of $40 \mathrm{~kg}$. 


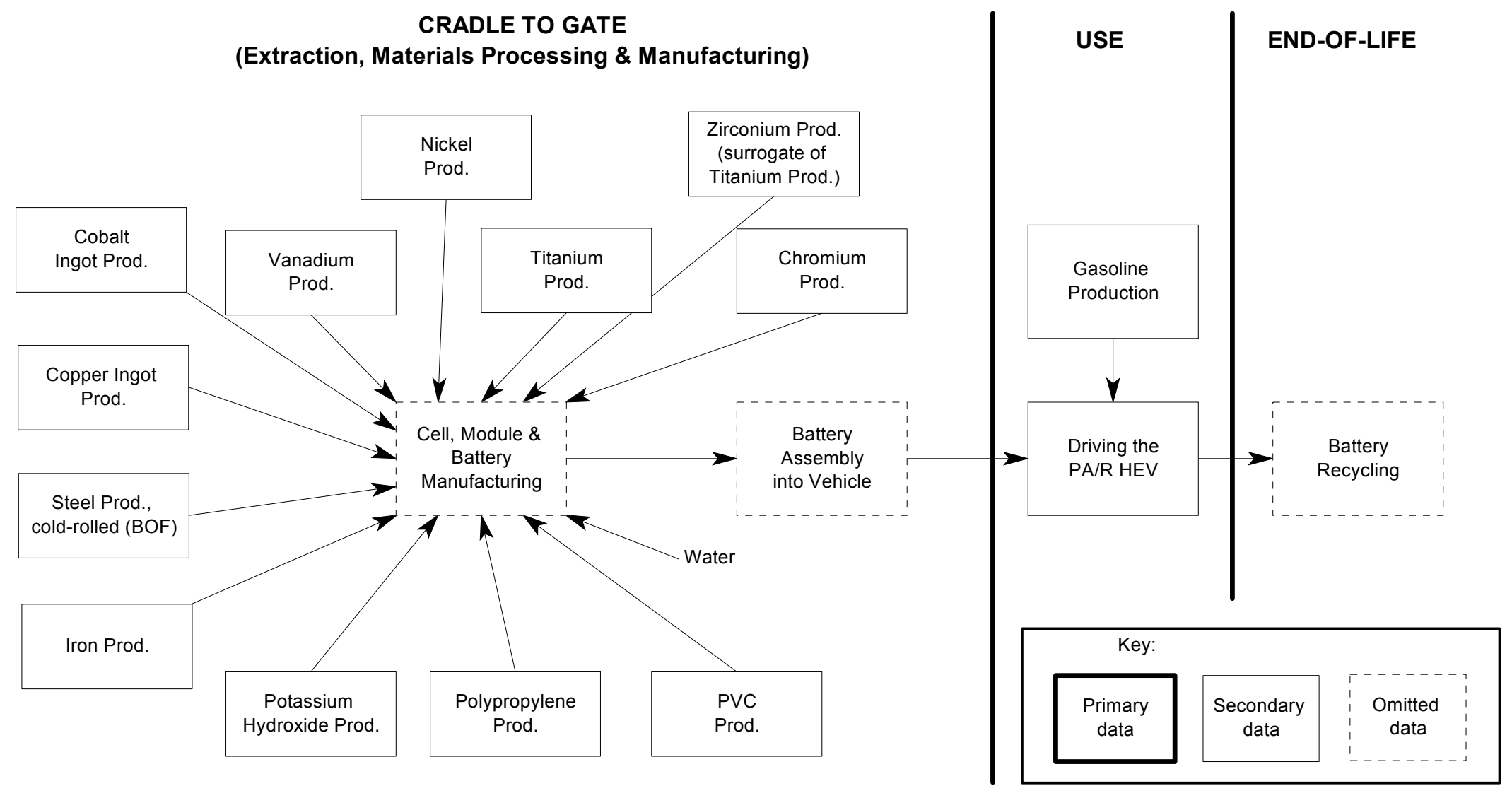

Figure 3.15. The NiMH HEV Battery Profile 


\subsubsection{NiMH and Lilon Battery Results}

The performance characteristics of batteries evaluated in this assessment are based on PNGV data that defined current technology in HEV battery development. A more forward-looking scenario, assuming a lighter weight for the NiMH battery and an increased life span for both battery types, is portrayed in the results for the long-term analyses (LiIon-LT and NiMH-LT).

Table 3.12 reveals some of the important data characteristics of the HEV batteries that were used to obtain the results, and also shows the emissions that were calculated from the Use lifecycle stage. Important items to re-mention with regard to this table include:

- the "current performance" NiMH battery weighed more than its LiIon counterpart, and a greater percentage of its materials were accounted for;

- the life span of the "current performance" NiMH battery was more than that of the LiIon;

- the weight difference for the "current performance" batteries has only a small effect on vehicle fuel efficiency, yet the Use stage emissions (associated only with each battery's mass) are reduced by as much as $33 \%$; and

- the two long-term batteries are equal in terms of mass and lifespan; thus, their comparison is essentially a comparison of the materials contained in them (focused on the E\&MP stage, in particular), while the environmental impacts in the Use stage are equal.

\begin{tabular}{|c|c|c|c|c|c|}
\hline \multicolumn{6}{|c|}{ Table 3.12. Profiles Evaluated for the HEV Battery Assessment } \\
\hline \multirow[t]{2}{*}{ Assessment Data } & \multirow[t]{2}{*}{ Units } & \multicolumn{4}{|c|}{ Profiles } \\
\hline & & LiIon & NiMH & LiIon-LT & NiMH-LT \\
\hline Mass of battery & $(\mathrm{kg})$ & 40.0 & 62.5 & 40.0 & 40.0 \\
\hline Total mass accounted for & $(\mathrm{kg})$ & 35.8 & 59.7 & 35.8 & 37.59 \\
\hline Percent total mass accounted for & $(\%)$ & $89.50 \%$ & $95.52 \%$ & $89.50 \%$ & $93.98 \%$ \\
\hline Mass of lithium / Ni+other hydride & $(\mathrm{kg})$ & 0.275 & $2.55+5.52$ & 0.275 & $2.19+4.75$ \\
\hline Life span & (years) & 3 & 5 & 10 & 10 \\
\hline Vehicle fuel efficiency & (mpg) & 80.0 & 78.9 & 80.0 & 80.0 \\
\hline Lifetime fuel consumed by vehicle & (lbs) & $9,231.0$ & $9,358.5$ & $9,231.0$ & $9,231.0$ \\
\hline Lifetime fuel consumed by battery & (lbs) & 325.7 & 506.0 & 325.7 & 325.7 \\
\hline \multicolumn{6}{|l|}{$\begin{array}{l}\text { Emissions from the Use Life-cycle } \\
\text { Stage }\end{array}$} \\
\hline $\mathrm{CH}_{4}$ & (lbs/use life) & 0.15 & 0.23 & 0.15 & 0.15 \\
\hline $\mathrm{CO}$ & (lbs/use life) & 9.34 & 14.30 & 9.34 & 9.34 \\
\hline $\mathrm{CO}_{2}$ & (lbs/use life) & $1,231.10$ & $1,912.21$ & $1,231.10$ & $1,231.10$ \\
\hline NMOG & (lbs/use life) & 0.09 & 0.14 & 0.09 & 0.09 \\
\hline NOx & (lbs/use life) & 0.19 & 0.29 & 0.19 & 0.19 \\
\hline PM & (lbs/use life) & 0.09 & 0.14 & 0.09 & 0.09 \\
\hline
\end{tabular}


The HEV Battery Assessment results are shown in Table 3.13. In reviewing the baseline comparison results, it is seen that the LiIon battery produces lower impact scores than the NiMH battery in 12 out of the 14 impact categories included in the analysis. In some of these cases, the differences are not great (e.g., nonrenewable resource use); in others, the differences are quite significant (e.g., acidification, hazardous waste landfill space, water quality - TSS). In the long-term (LT) comparison, similar results are seen, but with a reduced percentage difference between most of the impact scores. Within the LT comparison, using the LiIon-LT as the "baseline," the differences vary from as little as $0 \%$ (water quality - BOD) to as much as $\sim 300 \%$ (hazardous waste landfill space). Comparing across all of the four sets of results, one of the long-term profiles (LiIon-LT), as expected, has the lowest scores in most impact categories.

\begin{tabular}{|c|c|c|c|c|c|}
\hline \multicolumn{6}{|c|}{ Table 3.13. Impact Scores for the HEV Battery Assessment } \\
\hline Impact Category & Units & LiIon & NiMH & LiIon-LT & NiMH-LT \\
\hline \multicolumn{6}{|l|}{ Impacts from Inputs } \\
\hline Nonrenewable resource use & (lbs) & $1,735.48$ & $2,147.85$ & 821.43 & 929.57 \\
\hline Renewable resource use & (lbs) & $34,657.78$ & $60,908.46$ & $22,691.54$ & $27,782.33$ \\
\hline Energy use & (MMBTUs) & 21.47 & 27.78 & $\mathbf{1 1 . 6 6}$ & 13.57 \\
\hline \multicolumn{6}{|l|}{ Impacts from Outputs } \\
\hline Global warming & (lbs $\mathrm{CO}_{2}$-eq.) & $3,570.21$ & $4,815.48$ & $2,108.29$ & $2,388.65$ \\
\hline Ozone depletion & (lbs CFC11-eq.) & 0.00025 & 0.00090 & 0.00007 & 0.00037 \\
\hline Acidification & (lbs $\mathrm{SO}_{2}$-eq.) & 19.82 & 216.11 & 7.16 & 88.46 \\
\hline Smog & (lbs ethene-eq.) & 0.67 & 0.94 & 0.32 & 0.44 \\
\hline Particulates & (lbs PM) & 6.57 & 4.33 & 2.15 & 1.22 \\
\hline Odor (aesthetics) & $\left(\right.$ million $\left.\mathrm{m}^{3}\right)$ & 4.78 & 8.87 & 3.57 & 4.68 \\
\hline Solid waste landfill space & $\left(\mathrm{ft}^{3}\right)$ & 21.68 & 2.85 & 7.09 & 1.10 \\
\hline $\begin{array}{l}\text { Hazardous waste landfill } \\
\text { space }\end{array}$ & $\left(\mathrm{ft}^{3}\right)$ & 0.11 & 0.53 & 0.06 & 0.24 \\
\hline Eutrophication & $\begin{array}{l}\text { (lbs phosphate- } \\
\text { eq.) }\end{array}$ & 0.08 & 0.21 & 0.08 & 0.11 \\
\hline Water quality - BOD & (lbs BOD) & 0.34 & 0.50 & 0.32 & 0.32 \\
\hline Water quality - TSS & (lbs TSS) & 1.72 & 5.57 & 1.52 & 2.81 \\
\hline
\end{tabular}

Notes: Bold indicates lowest impact scores.

A comparative chart representing the ratio of the impact scores for the baseline profiles evaluated in the HEV battery assessment is shown in Figure 3.16. It is seen that LiIon has greater impacts only in the particulate matter and solid waste categories, while NiMH has greater impacts in all other categories. The key issues to point out would be the acidification difference (NiMH an order of magnitude higher that LiIon due to sulfur dioxide emissions from Nickel Production) and the solid waste landfill space difference (LiIon an order of magnitude higher than NiMH). These issues are discussed more in the focus (impact category-specific) graphs presented later in this section.

Figure 3.17 shows a comparison of the long-term LiIon and NiMH battery profiles. The picture here is similar to that of the comparison between the two current performance battery profiles. However, the water quality (BOD), which had a greater impact score for 


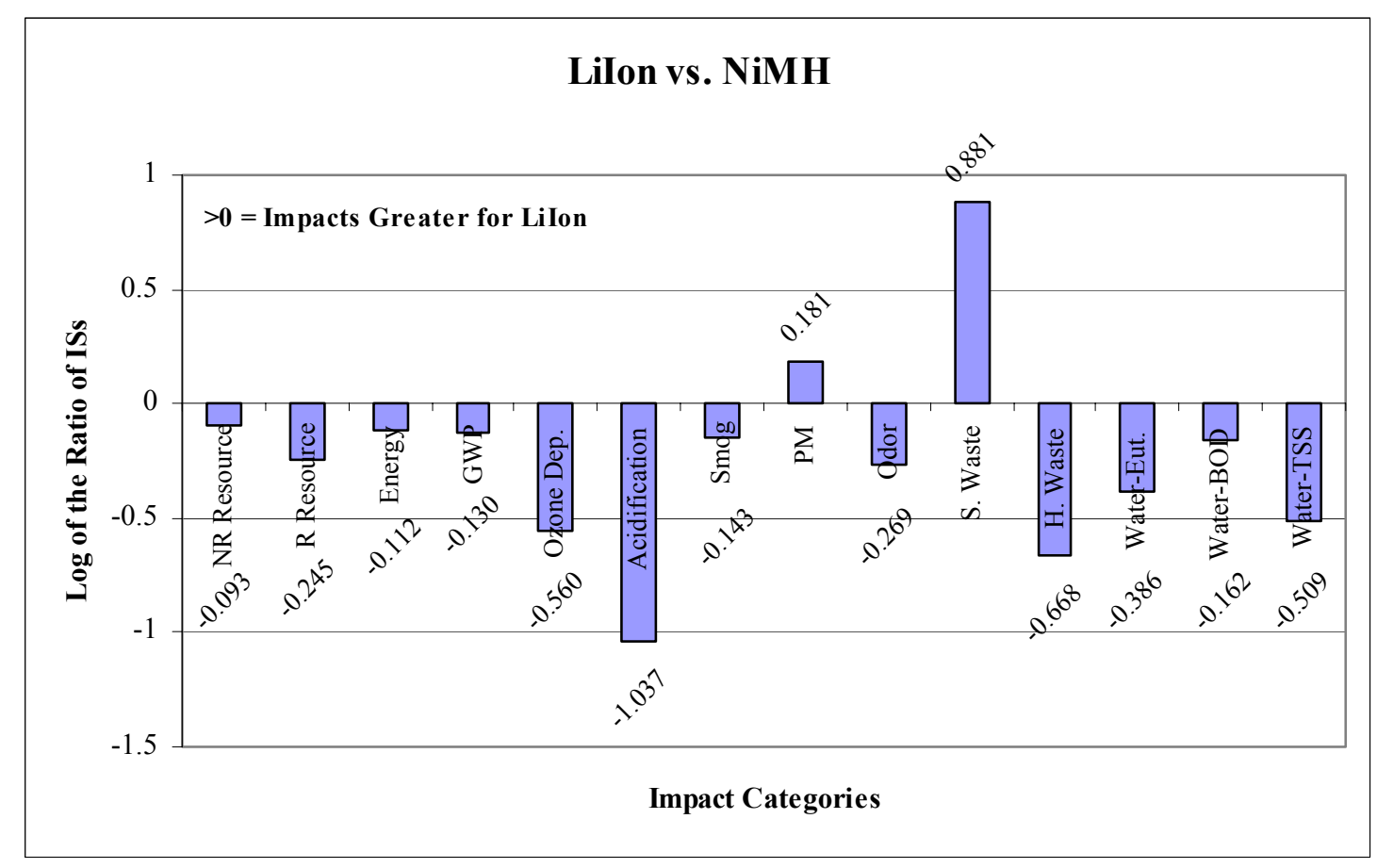

Figure 3.16. HEV Batteries - LiIon vs. NiMH Comparison

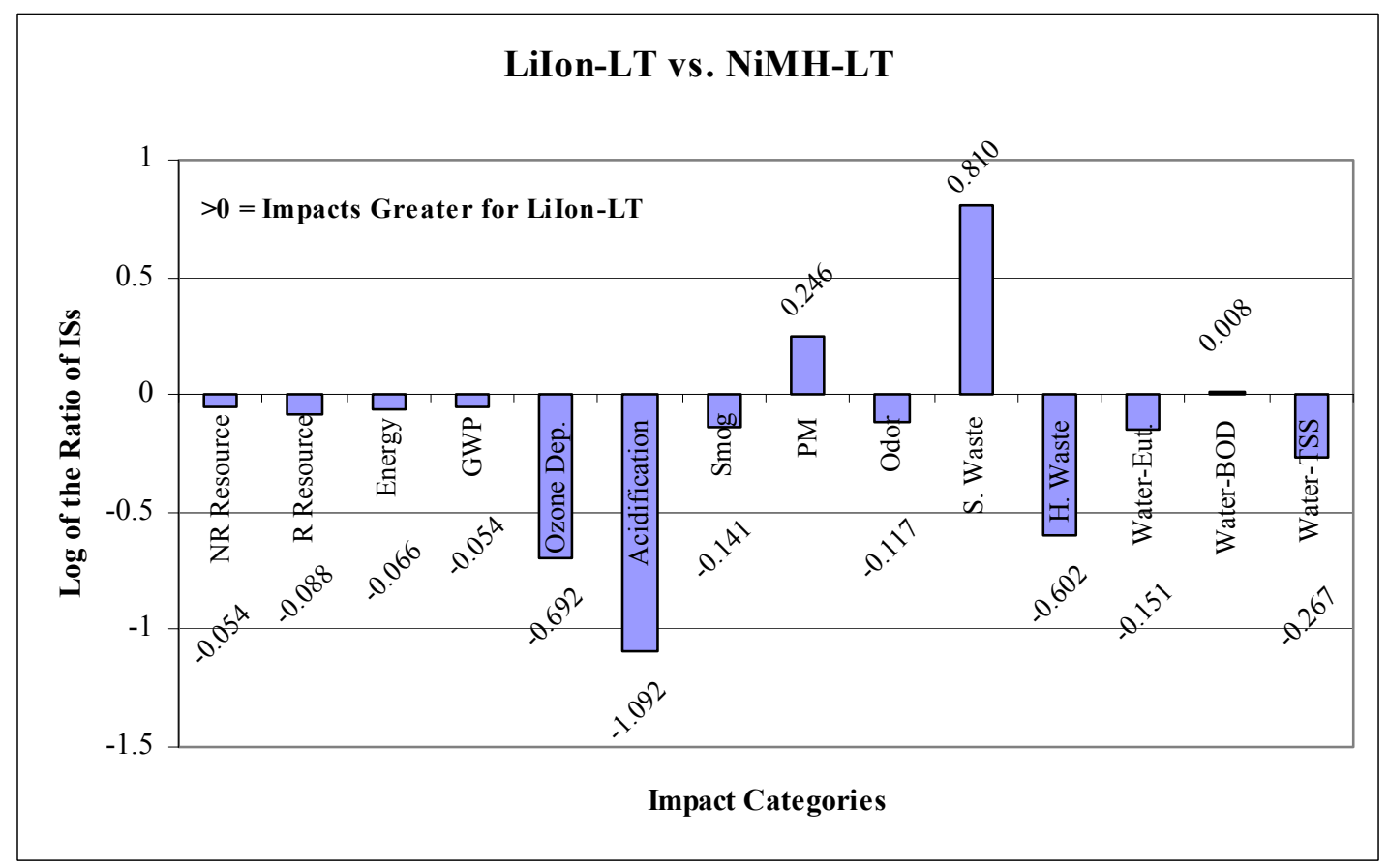

Figure 3.17. HEV Batteries - LiIon-LT vs. NiMH-LT Comparison 
$\mathrm{NiMH}$, now has an almost equal score for the two. This is because the mass of the NiMH battery has been reduced, while the mass of the LiIon battery still remains the same.

The projected improvements in battery life for the LiIon battery improve environmental performance dramatically (Figure 3.18). All the scores show considerable improvement in going from a life span of 3 years to 10 years, where only one battery is needed over the life of the vehicle instead of 3.3.

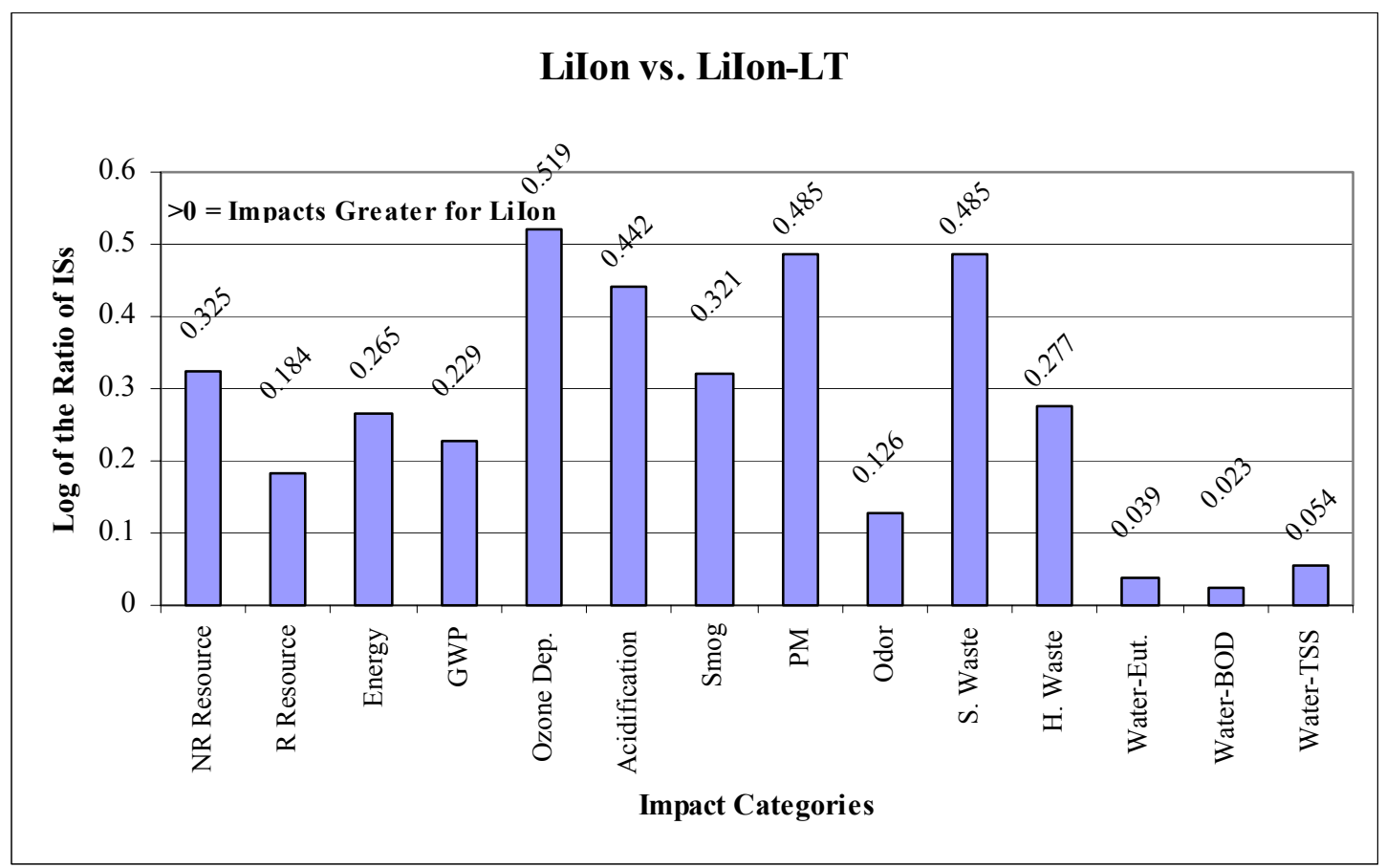

Figure 3.18. HEV Batteries - LiIon vs. LiIon-LT Comparison

For NiMH batteries, improvements in going from NiMH to NiMH-LT are quite significant, as two key variables were altered: a mass reduction of $36 \%$ (from $62.5 \mathrm{~kg}$ to $40 \mathrm{~kg}$ ), plus an increased life span (from 5 to 10 years). (See Figure 3.19.)

Four focus graphs were generated for this assessment, and they include the impact categories: energy use, GWP, acidification, and solid waste landfill space. For energy use (Figure 3.20) and GWP (Figure 3.21), the LiIon impact scores are less than those of NiMH in both of the depicted life-cycle stages (E\&MP and Use -Fuel Production and Fuel Use). However, in comparing the two long-term profiles, though LiIon-LT still has lower overall impacts than NiMH-LT, the differences are solely due to the E\&MP stage, while the Fuel Production and Fuel Use scores for the two are equal. Tables 3.14 and 3.15 show the life-cycle stage breakdown of the impact scores and the top three contributors to each score for the energy use and GWP impact categories, respectively. 


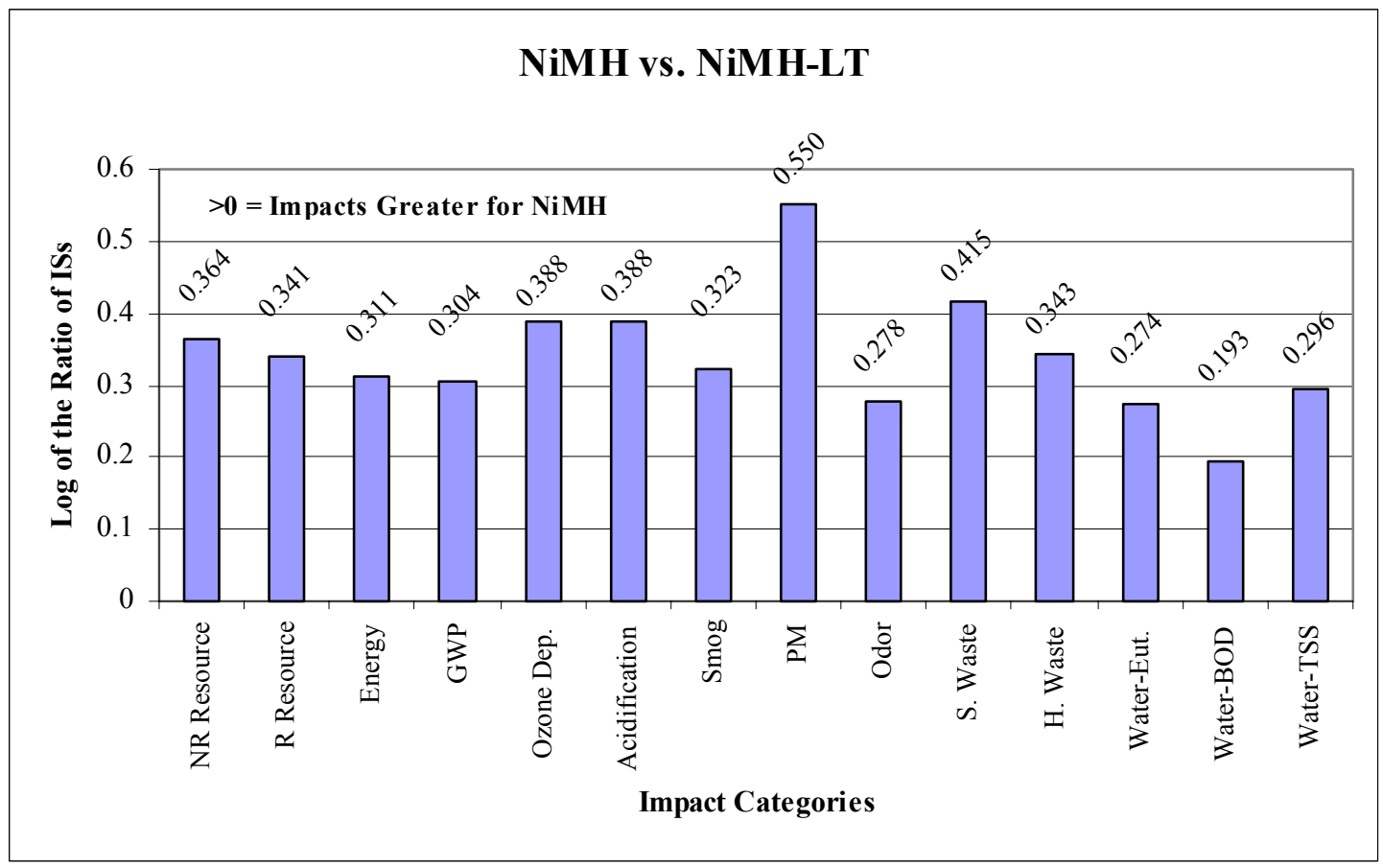

Figure 3.19. HEV Batteries - NiMH vs. NiMH-LT Comparison

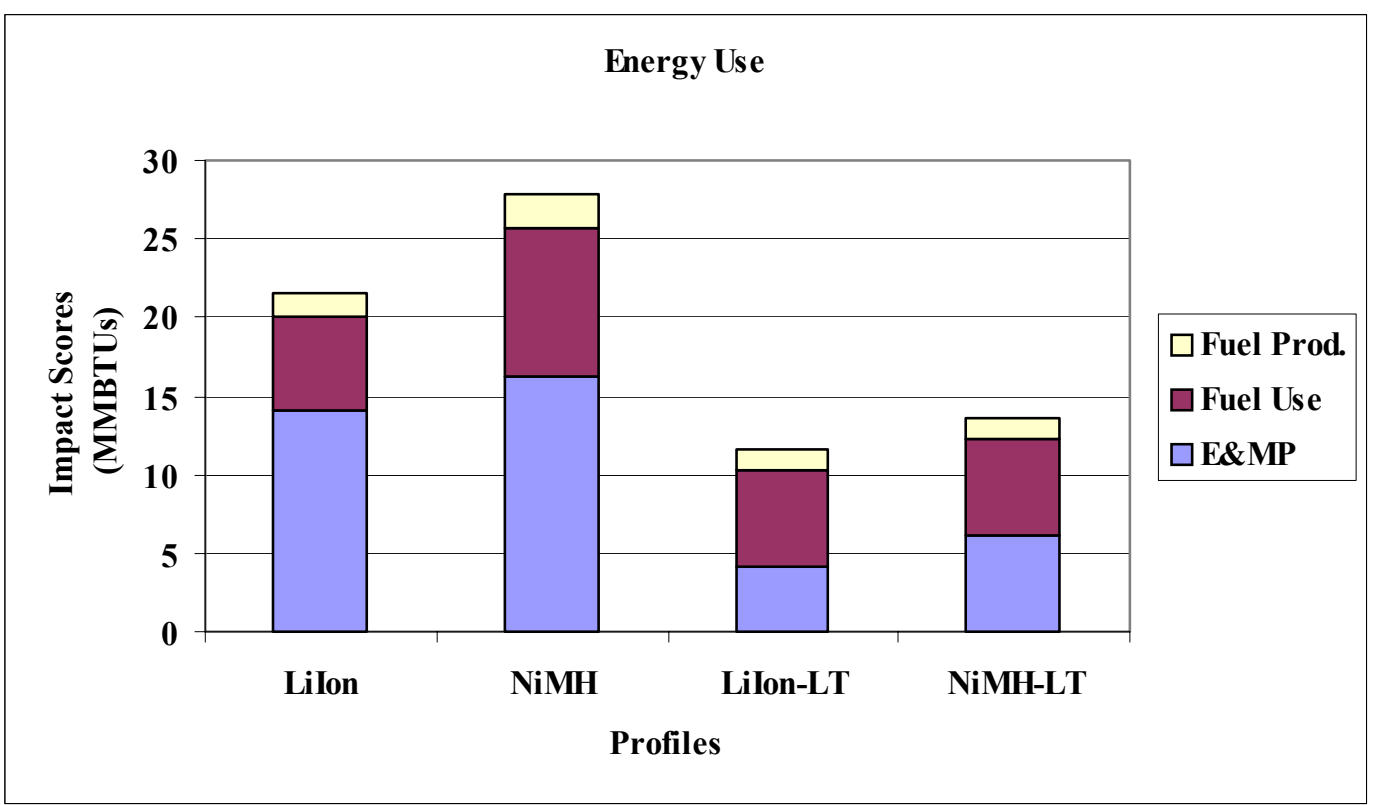

Figure 3.20. HEV Batteries - Energy Use 


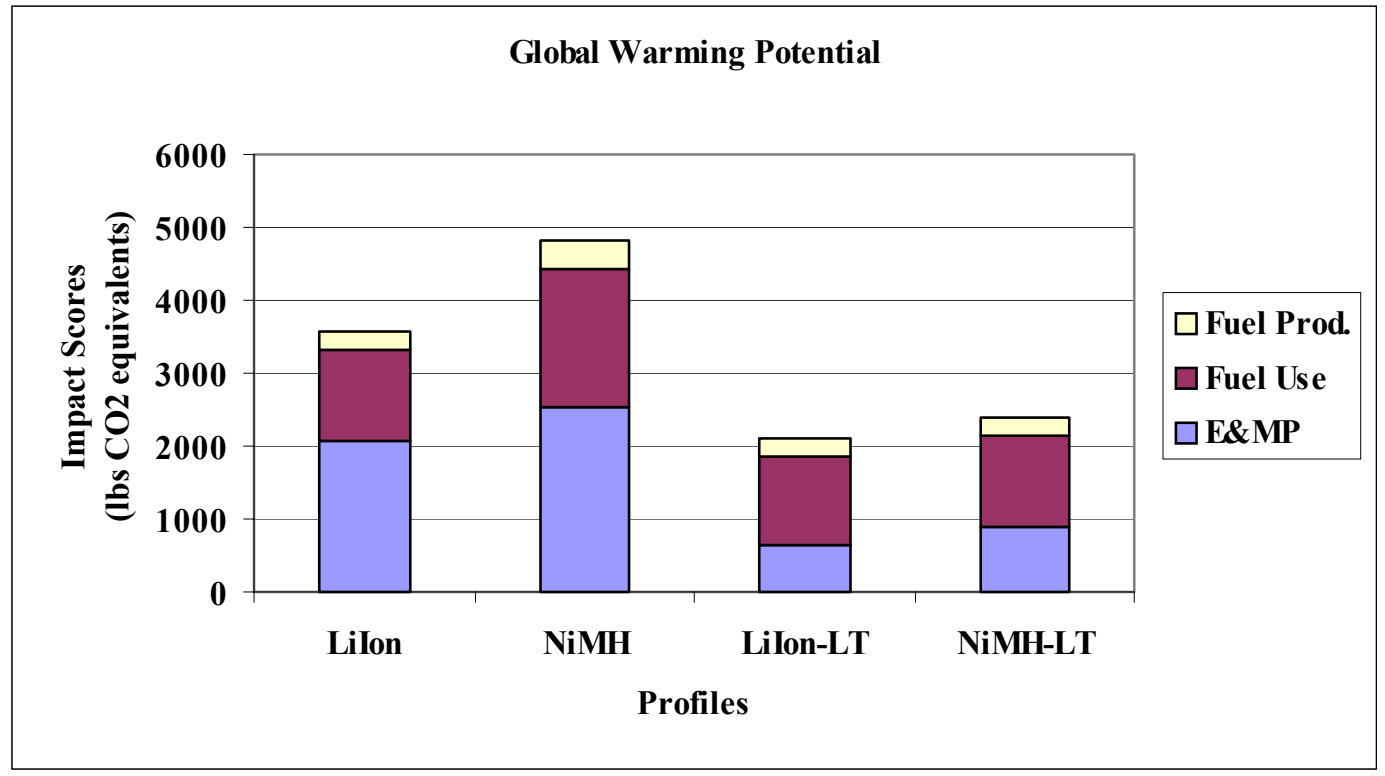

Figure 3.21. HEV Batteries - Global Warming Potential

\begin{tabular}{|c|c|c|c|c|c|}
\hline \multicolumn{6}{|c|}{$\begin{array}{c}\text { Table 3.14. Energy Use in the HEV Battery Assessment: } \\
\text { Life-cycle Stage Scores and Biggest Contributors }\end{array}$} \\
\hline $\begin{array}{l}\text { Energy Use } \\
\text { (MMBTUs) }\end{array}$ & E\&MP & $\begin{array}{c}\text { Use - } \\
\text { Fuel Use }\end{array}$ & $\begin{array}{c}\text { Use - } \\
\text { Fuel Prod. }\end{array}$ & EOL & Total \\
\hline LiIon & 14.01 & 6.11 & 1.35 & N/A & 21.47 \\
\hline NiMH & 16.20 & 9.49 & 2.09 & N/A & 27.78 \\
\hline LiIon-LT & 4.20 & 6.11 & 1.35 & N/A & 11.66 \\
\hline NiMH-LT & 6.12 & 6.11 & 1.35 & N/A & 13.57 \\
\hline $\begin{array}{l}\text { Biggest } \\
\text { Contributors }\end{array}$ & $\begin{array}{l}\text { Life-cycle } \\
\text { Stage }\end{array}$ & Process & Input & $\begin{array}{c}\text { Score } \\
(\mathrm{MMBTUs})\end{array}$ & $\begin{array}{c}\text { Percent of } \\
\text { Total }\end{array}$ \\
\hline LiIon - 1 & Use & Driving & Gasoline & 6.11 & $28.5 \%$ \\
\hline Lilon - 2 & E\&MP & $\begin{array}{l}\text { Aluminum } \\
\text { Prod. }\end{array}$ & Electricity & 4.99 & $23.2 \%$ \\
\hline Lilon -3 & E\&MP & $\begin{array}{l}\text { Aluminum } \\
\text { Prod. }\end{array}$ & Coal & 3.86 & $18.0 \%$ \\
\hline $\mathrm{NiMH}-1$ & Use & Driving & Gasoline & 9.49 & $34.2 \%$ \\
\hline $\mathrm{NiMH}-2$ & E\&MP & Nickel Prod. & Petroleum & 2.62 & $9.4 \%$ \\
\hline $\mathrm{NiMH}-3$ & E\&MP & Nickel Prod. & Coal & 2.39 & $8.6 \%$ \\
\hline LiIon-LT - 1 & Use & Driving & Gasoline & 6.11 & $52.4 \%$ \\
\hline LiIon-LT - 2 & E\&MP & $\begin{array}{l}\text { Aluminum } \\
\text { Prod. }\end{array}$ & Electricity & 1.50 & $12.8 \%$ \\
\hline LiIon-LT - 3 & Use & Gasoline Prod. & Natural gas & 1.18 & $10.1 \%$ \\
\hline NiMH-LT -1 & Use & Driving & Gasoline & 6.11 & $45.0 \%$ \\
\hline NiMH-LT - 2 & Use & Gasoline Prod. & Natural gas & 1.18 & $8.7 \%$ \\
\hline NiMH-LT - 3 & E\&MP & Nickel Prod. & Petroleum & 1.07 & $7.9 \%$ \\
\hline
\end{tabular}


The life-cycle stage breakdowns for the two "current performance" profiles (Table 3.14) show that E\&MP values are $~ 1.9$ times and $\sim 1.4$ times the entire Use life-cycle stage values for LiIon and NiMH respectively. For the LT profiles, the reduction of $\sim 10$ MMBTUs in the E\&MP stage reverses this relationship, making the Use stage more significant, as the E\&MP values become only $\sim 0.6$ times and $\sim 0.8$ times the Use stage values. This large decrease that can also be seen in the profile totals results in a $\sim 46 \%$ reduction between the two LiIon scenarios and a $\sim 51 \%$ reduction between the two $\mathrm{NiMH}$ scenarios.

Table 3.14 shows that Driving (Fuel Use) contributes from $\sim 29 \%-45 \%$ of the energy use impacts for all profiles except LiIon-LT, where driving accounts for over half of the total profile energy use. The remaining impacts are from the production of energy-intensive materials used in each of the batteries and the lifetime quantity of fuel (gasoline) required in each case. Gasoline production shows up as one of the top three contributors only for the long-term profiles. This is because of their lower lifetime energy totals, making Fuel Use more significant in their case than in the case of the current technology profiles. As for the materials, the big contributor is nickel for the NiMH profiles, and aluminum for the LiIon. Nickel is used in the NiMH battery in the anode, and in the cathode as nickel hydroxide and substrate material. Aluminum is used in the battery and cell containers and the current collector of the LiIon battery, and shows up as a big contributor due to its high energyintensity.

\begin{tabular}{|c|c|c|c|c|c|}
\hline \multicolumn{6}{|c|}{$\begin{array}{l}\text { Table 3.15. Global Warming Potential in the HEV Battery Assessment: } \\
\text { Life-cycle Stage Scores and Biggest Contributors }\end{array}$} \\
\hline $\begin{array}{l}\text { GWP } \\
\text { (lbs } \mathrm{CO}_{2} \text { equiv.) }\end{array}$ & $\overline{\text { E\&MP }}$ & $\begin{array}{c}\text { Use - } \\
\text { Fuel Use }\end{array}$ & $\begin{array}{l}\text { Use - } \\
\text { Fuel } \\
\text { Prod. }\end{array}$ & $\overline{\text { EOL }}$ & Total \\
\hline LiIon & $2,088.46$ & $1,235.09$ & 246.66 & N/A & $3,570.21$ \\
\hline NiMH & $2,540.12$ & $1,892.24$ & 383.12 & N/A & $4,815.48$ \\
\hline LiIon-LT & 626.54 & $1,235.09$ & 246.66 & N/A & $2,108.29$ \\
\hline NiMH-LT & 906.90 & $1,235.09$ & 246.66 & $\mathrm{~N} / \mathrm{A}$ & $2,388.65$ \\
\hline $\begin{array}{l}\text { Biggest } \\
\text { Contributors }\end{array}$ & $\begin{array}{l}\text { Life-cycle } \\
\text { Stage }\end{array}$ & Process & Output & $\begin{array}{c}\text { Score } \\
\text { (lbs CO } 2 \\
\text { equiv.) }\end{array}$ & $\begin{array}{l}\text { Percent } \\
\text { of Total }\end{array}$ \\
\hline LiIon - 1 & E\&MP & $\begin{array}{l}\text { Aluminum } \\
\text { Prod. }\end{array}$ & $\mathrm{CO}_{2}$ & $1,310.71$ & $36.7 \%$ \\
\hline LiIon - 2 & Use & Driving & $\mathrm{CO}_{2}$ & $1,231.10$ & $34.5 \%$ \\
\hline LiIon -3 & Use & Gasoline Prod. & $\mathrm{CO}_{2}$ & 218.33 & $6.1 \%$ \\
\hline NiMH -1 & Use & Driving & $\mathrm{CO}_{2}$ & $1,886.15$ & $39.2 \%$ \\
\hline $\mathrm{NiMH}-2$ & E\&MP & Nickel Prod. & $\mathrm{CO}_{2}$ & $1,171.55$ & $24.3 \%$ \\
\hline $\mathrm{NiMH}-3$ & E\&MP & Titanium Prod. & $\mathrm{CO}_{2}$ & 605.65 & $12.6 \%$ \\
\hline LiIon-LT - 1 & Use & Driving & $\mathrm{CO}_{2}$ & $1,231.10$ & $58.4 \%$ \\
\hline LiIon-LT - 2 & E\&MP & $\begin{array}{l}\text { Aluminum } \\
\text { Prod. }\end{array}$ & $\mathrm{CO}_{2}$ & 393.21 & $18.7 \%$ \\
\hline LiIon-LT - 3 & Use & Gasoline Prod. & $\mathrm{CO}_{2}$ & 218.33 & $10.4 \%$ \\
\hline NiMH-LT -1 & Use & Driving & $\mathrm{CO}_{2}$ & $1,231.10$ & $51.5 \%$ \\
\hline NiMH-LT - 2 & E\&MP & Nickel Prod. & $\mathrm{CO}_{2}$ & 479.67 & $20.1 \%$ \\
\hline NiMH-LT - 3 & E\&MP & Titanium Prod. & $\mathrm{CO}_{2}$ & 260.78 & $10.9 \%$ \\
\hline
\end{tabular}


As with energy use, LiIon has lower global warming potential scores than NiMH in both lifecycle stages (Table 3.15). As this impact category is somewhat tied to the energy use impact category, the results are similar. Also, for the two current-technology batteries, the emissions from E\&MP (upstream) are greater than the emissions from the Use life-cycle stage (includings fuel use and fuel production). This contrasts to vehicles as a whole, in which the Use life-cycle stage is typically more significant in many air emission impact categories than the other life-cycle stages, and these results imply that both batteries can improve the GWP "footprint." This improvement is realized in going from current technology to the long-term, as is revealed in the GWP impact results for the LiIon-LT and NiMH-LT profiles. Both have a lower GWP impact score for E\&MP than for the Use stage.

From among the biggest contributors, driving (Fuel Use) gets the top spot in all except the "current performance" LiIon battery profile. For this profile, the choice of aluminum as a cell container creates higher GWP impacts because of the energy intensity of virgin aluminum production (also visible in the energy use results). Aluminum production, however, is overshadowed by driving, in going from current technology to long-term, as seen in the GWP impacts for the LiIon-LT profile. The other top contributors to NiMH profiles' global warming impacts are nickel and titanium (the latter used instead of zirconium; see Table 3.10), both energy-intensive materials, contributing considerably to GWP.

In the acidification impact category (Figure 3.22), the NiMH profiles' results are driven by the contribution of sulfur dioxide from nickel production, accounting for almost $95 \%$ of the results for $\mathrm{NiMH}$.

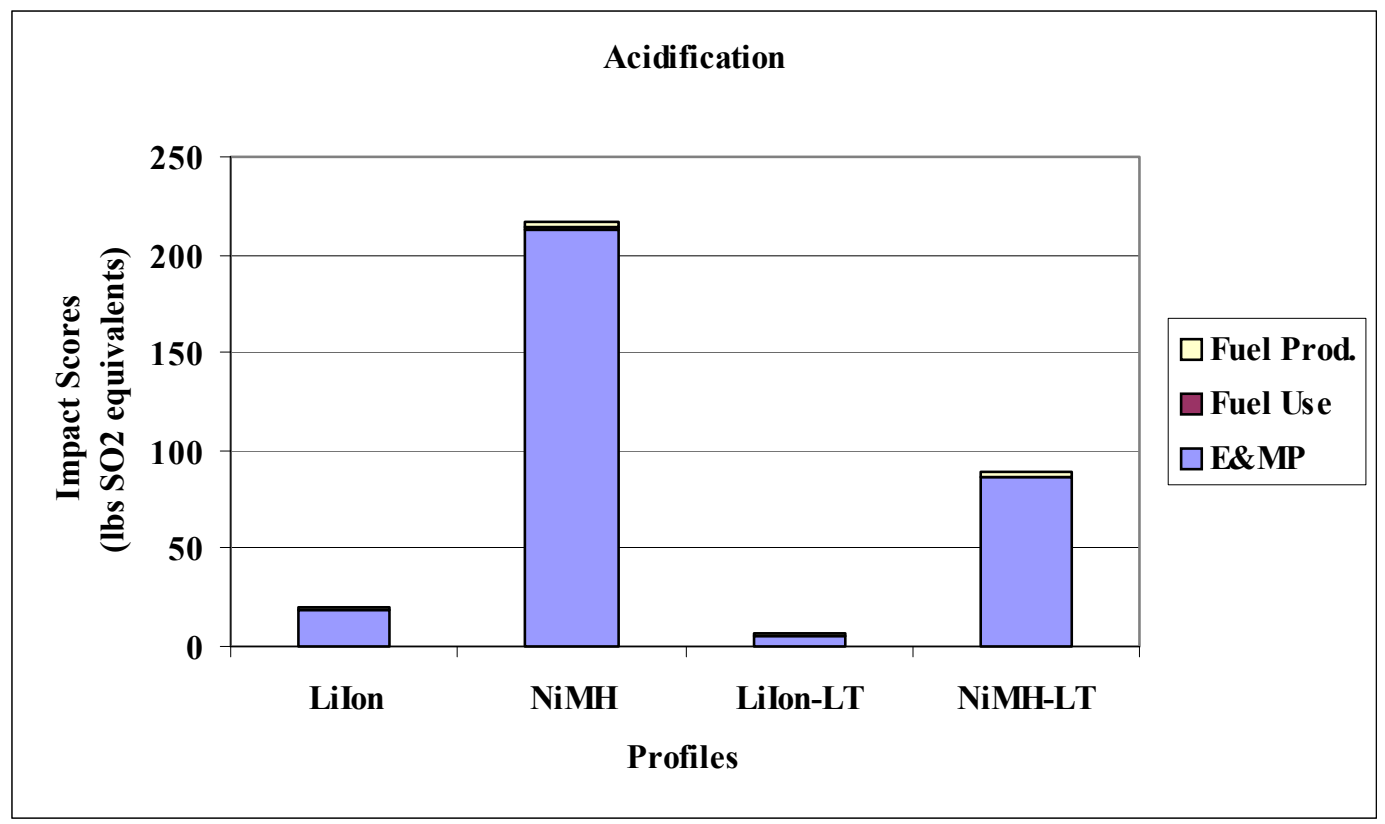

Figure 3.22. HEV Batteries - Acidification 
Although the pattern of acidification scores for Fuel Use and Fuel Production (Table 3.16) is similar to other impact categories, the sulfur dioxide emissions from E\&MP take the acidification scores for the NiMH batteries an order of magnitude higher than those for LiIon.

\begin{tabular}{|c|c|c|c|c|c|}
\hline \multicolumn{6}{|c|}{$\begin{array}{c}\text { Table 3.16. Acidification in the HEV Battery Assessment: } \\
\text { Life-cycle Stage Scores and Biggest Contributors }\end{array}$} \\
\hline $\begin{array}{l}\text { Acidification } \\
\text { (lbs } \mathrm{SO}_{2} \text { equiv.) }\end{array}$ & E\&MP & $\begin{array}{c}\text { Use - } \\
\text { Fuel Use }\end{array}$ & $\begin{array}{c}\text { Use - } \\
\text { Fuel Prod. }\end{array}$ & $\overline{\text { EOL }}$ & Total \\
\hline LiIon & 18.09 & 0.13 & 1.60 & $\mathrm{~N} / \mathrm{A}$ & 19.82 \\
\hline NiMH & 213.42 & 0.20 & 2.49 & N/A & 216.11 \\
\hline LiIon-LT & 5.43 & 0.13 & 1.60 & $\mathrm{~N} / \mathrm{A}$ & 7.16 \\
\hline NiMH-LT & 86.73 & 0.13 & 1.60 & N/A & 88.46 \\
\hline $\begin{array}{l}\text { Biggest } \\
\text { Contributors }\end{array}$ & $\begin{array}{l}\text { Life-cycle } \\
\text { Stage }\end{array}$ & Process & Output & $\begin{array}{c}\text { Score } \\
\text { (lbs } \mathrm{SO}_{2} \\
\text { equiv.) }\end{array}$ & $\begin{array}{l}\text { Percent } \\
\text { of Total }\end{array}$ \\
\hline LiIon - 1 & E\&MP & $\begin{array}{l}\text { Aluminum } \\
\text { Prod. }\end{array}$ & SOx & 5.62 & $28.4 \%$ \\
\hline LiIon -2 & E\&MP & Copper Prod. & $\mathrm{SO}_{2}$ & 5.21 & $26.3 \%$ \\
\hline LiIon -3 & E\&MP & $\begin{array}{l}\text { Aluminum } \\
\text { Prod. }\end{array}$ & NOx & 3.20 & $16.1 \%$ \\
\hline $\mathrm{NiMH}-1$ & E\&MP & Nickel Prod. & $\mathrm{SO}_{2}$ & 204.40 & $94.6 \%$ \\
\hline $\mathrm{NiMH}-2$ & E\&MP & Titanium Prod. & SOx & 2.02 & $0.9 \%$ \\
\hline $\mathrm{NiMH}-3$ & E\&MP & Nickel Prod. & $\mathrm{NO}_{2}$ & 1.74 & $0.8 \%$ \\
\hline LiIon-LT - 1 & E\&MP & $\begin{array}{l}\text { Aluminum } \\
\text { Prod. }\end{array}$ & $\mathrm{SOx}$ & 1.69 & $23.6 \%$ \\
\hline LiIon-LT - 2 & E\&MP & Copper Prod. & $\mathrm{SO}_{2}$ & 1.56 & $21.8 \%$ \\
\hline LiIon-LT - 3 & Use & Gasoline Prod. & $\mathrm{SO}_{2}$ & 1.05 & $14.7 \%$ \\
\hline NiMH-LT -1 & E\&MP & Nickel Prod. & $\mathrm{SO}_{2}$ & 83.69 & $94.6 \%$ \\
\hline NiMH-LT - 2 & Use & Gasoline Prod. & $\mathrm{SO}_{2}$ & 1.05 & $1.2 \%$ \\
\hline NiMH-LT - 3 & E\&MP & Titanium Prod. & SOx & 0.87 & $1.0 \%$ \\
\hline
\end{tabular}

For the acidification impact category, most of the big contributors are from E\&MP and point to the more energy- and materials-intensive materials. In the case of the two long-term profiles, gasoline production shows up as one of the contributors, accounting for about $15 \%$ of the impacts for LiIon-LT, but only $1.2 \%$ for NiMH-LT. This is because nickel production clearly dominates the acidification impacts for $\mathrm{NiMH}$ batteries, contributing $95 \%$ of the total values in each case. Nitrogen oxides and sulfur oxides emissions from the production of aluminum, copper, and titanium are responsible for the rest of the acidification impacts.

In the final focus graph for this assessment, the solid waste landfill space impact category is looked at more closely (see Figure 3.23 and Table 3.17). In this breakdown, the results flip as compared to the other focus graphs included in this assessment: NiMH has a much lower total score than LiIon, for both the "current performance" and long-term scenarios. Solid wastes from aluminum production alone contribute significantly more to the total score for LiIon than the total life-cycle score for NiMH. However, in looking at the Use life-cycle stage alone 


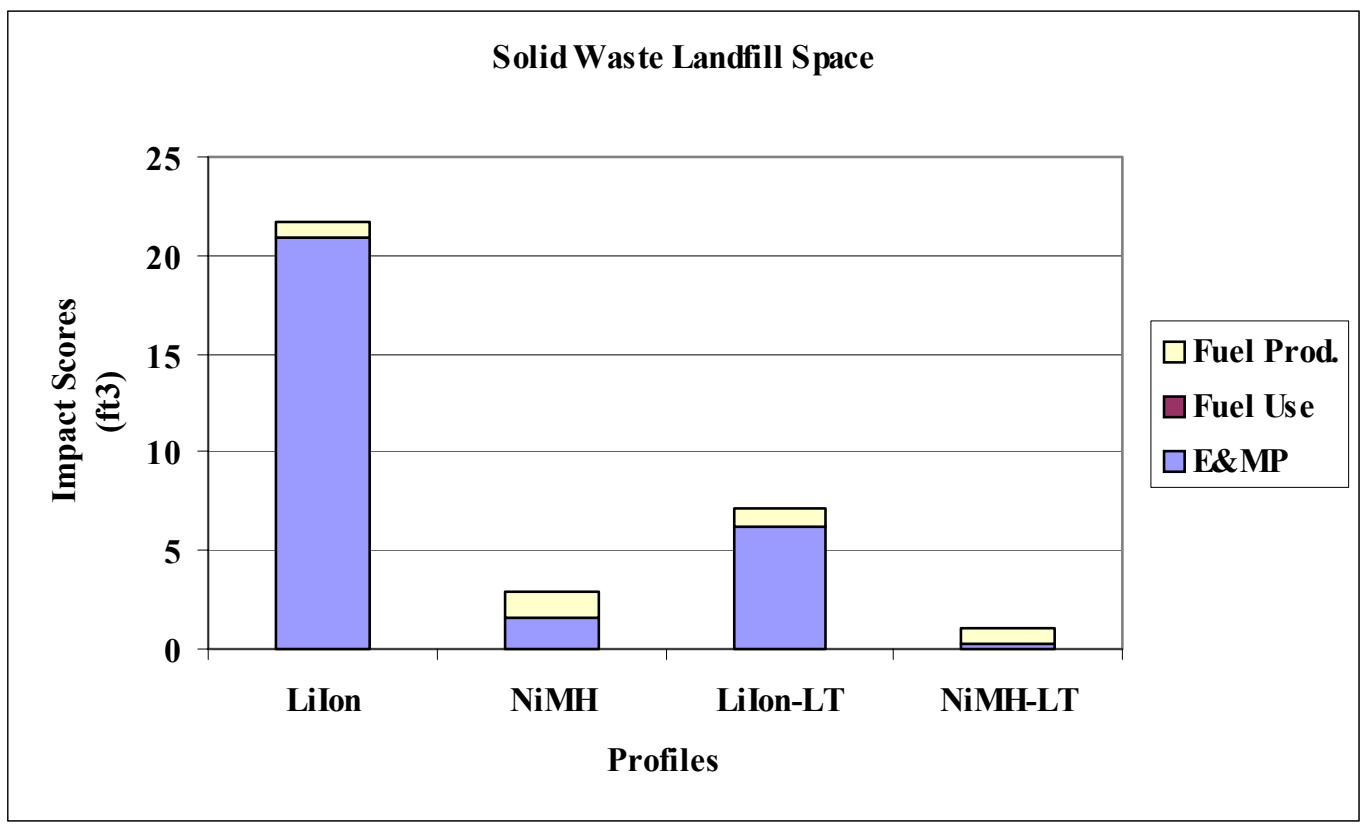

Figure 3.23. HEV Batteries - Solid Waste Landfill Space

\begin{tabular}{|c|c|c|c|c|c|}
\hline \multicolumn{6}{|c|}{$\begin{array}{l}\text { Table 3.17. Solid Waste Landfill Space in the HEV Battery Assessment: } \\
\text { Life-cycle Stage Scores and Biggest Contributors }\end{array}$} \\
\hline $\begin{array}{l}\text { SWLS } \\
\left(\mathrm{ft}^{3}\right)\end{array}$ & E\&MP & $\begin{array}{c}\text { Use - } \\
\text { Fuel Use }\end{array}$ & $\begin{array}{c}\text { Use - } \\
\text { Fuel Prod. }\end{array}$ & EOL & Total \\
\hline LiIon & 20.85 & 0 & 0.84 & N/A & 21.68 \\
\hline NiMH & 1.55 & 0 & 1.30 & N/A & 2.85 \\
\hline LiIon-LT & 6.25 & 0 & 0.84 & N/A & 7.09 \\
\hline NiMH-LT & 0.26 & 0 & 0.84 & N/A & 1.10 \\
\hline $\begin{array}{l}\text { Biggest } \\
\text { Contributors }\end{array}$ & $\begin{array}{l}\text { Life- } \\
\text { cycle } \\
\text { Stage }\end{array}$ & Process & $\overline{\text { Output }}$ & Score $\left(\mathrm{ft}^{3}\right)$ & $\begin{array}{l}\text { Percent } \\
\text { of Total }\end{array}$ \\
\hline LiIon -1 & E\&MP & Aluminum Prod. & Slag and ash & 16.06 & $74.1 \%$ \\
\hline LiIon -2 & E\&MP & Aluminum Prod. & Unspecified solid waste & 3.63 & $16.7 \%$ \\
\hline LiIon -3 & Use & Gasoline Prod. & Slag and ash & 0.66 & $3.0 \%$ \\
\hline $\mathrm{NiMH}-1$ & Use & Gasoline Prod. & Slag and ash & 1.02 & $35.8 \%$ \\
\hline $\mathrm{NiMH}-2$ & E\&MP & Steel Prod. & Unspecified solid waste & 0.57 & $20.0 \%$ \\
\hline $\mathrm{NiMH}-3$ & E\&MP & Steel Prod. & Slag and ash & 0.34 & $11.9 \%$ \\
\hline LiIon-LT - 1 & E\&MP & Aluminum Prod. & Slag and ash & 4.82 & $68.0 \%$ \\
\hline LiIon-LT - 2 & E\&MP & Aluminum Prod. & Unspecified solid waste & 1.09 & $15.4 \%$ \\
\hline LiIon-LT - 3 & Use & Gasoline Prod. & Slag and ash & 0.66 & $9.3 \%$ \\
\hline NiMH-LT -1 & Use & Gasoline Prod. & Slag and ash & 0.66 & $59.9 \%$ \\
\hline NiMH-LT -2 & Use & Gasoline Prod. & Unspecified solid waste & 0.14 & $12.9 \%$ \\
\hline NiMH-LT -3 & E\&MP & $\begin{array}{l}\text { Potassium } \\
\text { Hydroxide Prod. }\end{array}$ & $\begin{array}{l}\text { Non mineral waste } \\
\text { (inert) }\end{array}$ & 0.11 & $9.8 \%$ \\
\hline
\end{tabular}


(Fuel Use and Fuel Production), LiIon is the better performer, with a lower score in the case of current performance profiles and a score equal to that of NiMH when the two long-term profiles are compared.

The biggest contributors to the LiIon impact scores in this category are solid wastes generated in the production of aluminum, accounting for almost $91 \%$ of the total score in the case of the "current performance" LiIon. The impact score in the Use life-cycle stage is equal for the two long-term batteries, and only slightly higher for NiMH, as compared to LiIon. However, looking at just the NiMH battery profiles, the biggest contributor to the solid waste landfill space score is gasoline production, contributing to the extent of about $73 \%$ in the case of NiMH-LT, and about $36 \%$ in the case of the "current performance" NiMH. Steel production shows up as another major contributor for $\mathrm{NiMH}$, accounting for approximately $32 \%$ of the total impact score. Stainless steel is replaced by polypropylene as the casing material for the NiMH-LT battery and steel production, therefore, drops off the list of biggest contributors for that profile.

\subsection{FUEL CELL VEHICLE ASSESSMENT}

\subsubsection{Background and Scope}

Fuel cells have attracted a great deal of attention in the last few years as potential replacements for conventional gasoline- or diesel-powered internal combustion engines. Because the technology for producing fuel cells at reasonable cost is still under development, they are seen more as a long-term solution for providing a clean, efficient means of generating electric power for future transportation needs. Fuel cells generate zero to very little pollution, depending on the type of fuel used for providing the hydrogen gas that is required for them to operate. If hydrogen gas is supplied directly to the vehicle, the vehicle is termed a directhydrogen fuel cell vehicle (FCV). If any other type of fuel is supplied to the vehicle (options include natural gas, methanol, ethanol, and gasoline), a fuel-reforming system must be included on-board to extract the hydrogen from the supplied fuel (except for a type of FCV called the "direct methanol FCV," which does not need a reformer). While the fuel reforming process does ease some issues about developing a hydrogen infrastructure, it does generate some emissions and brings significant, additional complexity into the FCV design process.

This study evaluated the potential life-cycle environmental impacts of a FCV using a $50 \mathrm{~kW}$ proton exchange membrane (PEM) fuel cell system (both with and without a fuel reformer), and compared them with those of a gasoline-fueled internal combustion engine vehicle (ICEV). The fuels considered for the fuel cell systems were direct hydrogen (without reformer), and methanol and gasoline (with reformer). Exclusive of the propulsion systems, the rest of the vehicle was assumed to be the same across all the profiles.

The functional and service units for this assessment were defined as one mid-sized vehicle, powered by different propulsion systems over a lifetime of 120,000 miles. 


\subsubsection{Assessment-Specific Assumptions}

Assumptions that relate to each of the scenarios are identified here.

1) The mid-sized passenger cars compared in this assessment were the

- 1994 Taurus-class sedan $\rightarrow$ the 'baseline' ICEV

- Hydrogen-fueled FCV (without reformer) $\rightarrow \mathrm{H} 2 \mathrm{FCV}$

- Methanol-fueled FCV (with reformer) $\rightarrow$ RFCV-MeOH

- Gasoline-fueled FCV (with reformer) $\rightarrow$ RFCV-gas

- Gasoline-fueled FCV (with reformer, Long-term) $\rightarrow$ RFCV-gas-LT

2) A materials breakdown was obtained from Arthur D. Little for a $50 \mathrm{~kW}$ fuel cell system (modeled by them for a cost assessment project for DOE), which formed the basis for the calculations (Carlson 2001).

3) It was assumed that a $50 \mathrm{~kW}$ fuel cell system is capable of delivering performance equivalent to that of a conventional ICE-powered mid-size vehicle, due to the improved torque characteristics of electric motors over internal combustion engines (SAE 2001). The Taurus-class vehicle used as the baseline in this analysis has a power rating of approximately $110 \mathrm{~kW}$.

4) The list of components assumed to be replaced in a conventional ICEV when switching to a FC-based propulsion system are:

- Engine (cylinder head, engine block, fuel injection system, engine air system, ignition system, starter system, generator, and lubrication system)

- Cooling system (water pump, radiator, and fan)

- Air cleaning system (air filter, etc.)

- Exhaust system (catalytic converter, heat shields, muffler, and exhaust piping)

- Lead-acid SLI battery

5) The fuel supply system was excluded from each profile evaluated, primarily due to uncertainty in the choice of a suitable hydrogen storage system (compressed, liquefied, or hydride).

6) Fuel efficiency of the 1994 vehicle was assumed to be the PNGV baseline, $26.6 \mathrm{mpg}$.

7) FCV fuel efficiencies were based on scaling factors obtained from Greet 1.5a (Wang 2000a, 2000b), in mpg for the gasoline FCV and miles per gallon gasoline equivalent (mpgge) $)^{j}$ for the hydrogen and methanol FCVs. Where needed, mpgge values were converted to mpg values using the ratios of lower heat values of each fuel to gasoline, using the following equation (NREL 2001; Thomas, James and Lomax 2000).

$$
\text { mpg }=\text { mpgge } \mathrm{x} \frac{\text { Lower Heat Value of Alternative Fuel }}{\text { Lower Heat Value of Gasoline }}
$$

8) Lifetime fuel requirement and emissions comparisons for each vehicle were based on a service life of 120,000 miles. The following formulas were used to compute the lifetime fuel required for each vehicle.

$$
\begin{array}{cc}
\text { Miles per } \mathrm{lb} \text { of fuel used } & =\frac{\mathrm{mpg}}{\text { density in } \mathrm{lbs} / \mathrm{gal} \text { of fuel }} \\
\text { Lifetime fuel used (in } \mathrm{kg} \text { ) } & =\frac{120,000 \text { miles }}{\text { Miles per } \mathrm{lb} \times 2.205}
\end{array}
$$

\footnotetext{
j The term "gallon gasoline equivalent" or "gge," often used in the context of alternative fuels, is the volume of alternative fuel it takes to equal the energy content of one gallon of gasoline.
} 
9) It was assumed that each propulsion system would last the life of the vehicle.

10) NMOGs (Non-methane Organic Gases) in the new Tier 2 standards were assumed to be the same as NMHCs (Non-methane Hydrocarbons).

11) For EOL processing, it was assumed that all the materials undergo separation by way of shredding and nonferrous metal separation into 3 material streams: ferrous, nonferrous, and ASR; all metals are recycled and all non-metals are landfilled as ASR.

\subsubsection{Baseline Vehicle}

Assumptions specific to the baseline vehicle are

1) Use stage emissions were based on previous work (average emissions from EPA testing of vehicles in the Taurus class).

2) The materials breakdown of the components replaced in an ICEV was obtained from previous work done by the CCPCT.

3) Figure 3.24 shows a graphical representation of the baseline vehicle propulsion system profile. (Note that the figure represents only the propulsion system profile, not the entire vehicle profile.)

\subsubsection{Direct Hydrogen Fuel Cell Vehicle}

Assumptions specific to the hydrogen fuel cell vehicle are

1) The fuel used was gaseous hydrogen (produced from natural gas cracking).

2) Hydrogen production data included compression.

3) Zero emissions were assumed during the use stage (Wang 2000a, California Energy Commission 2001, Fuel Cells 2000, 2001). ${ }^{\mathrm{k}}$

4) Figure 3.25 is a graphical representation of the FCV propulsion system profile. (Note that the figure represents only the propulsion system, not the entire vehicle profile.)

\subsubsection{Methanol- and Gasoline-fueled Fuel Cell Vehicles}

Assumptions specific to methanal and gasoline-fueled fuel cell vehicles are

1) NMOG, NOx, and PM emissions were obtained directly from Tier 2, Bin 2, based on PNGV targets (Wilson, Mullen and Laich, 2000).

2) $\mathrm{CO}, \mathrm{CO}_{2}$, and $\mathrm{CH}_{4}$ emissions were calculated using reduction factors obtained from Greet 1.5a $\left(\mathrm{CO}_{2}\right.$ and $\mathrm{CH}_{4}$ were not available in Tier 2, while $\mathrm{CO}$ emissions in the standard were much higher than even our baseline).

3) Figure 3.25 is a graphical representation of the FCV propulsion system profile.

\footnotetext{
${ }^{\mathrm{k}}$ In the reference to Wang 2000a, the PM-10 emissions shown are from brake and tire wear, and not from fuel cell system operation.
} 
CRADLE TO GATE

(Extraction, Materials Processing \& Manufacturing)

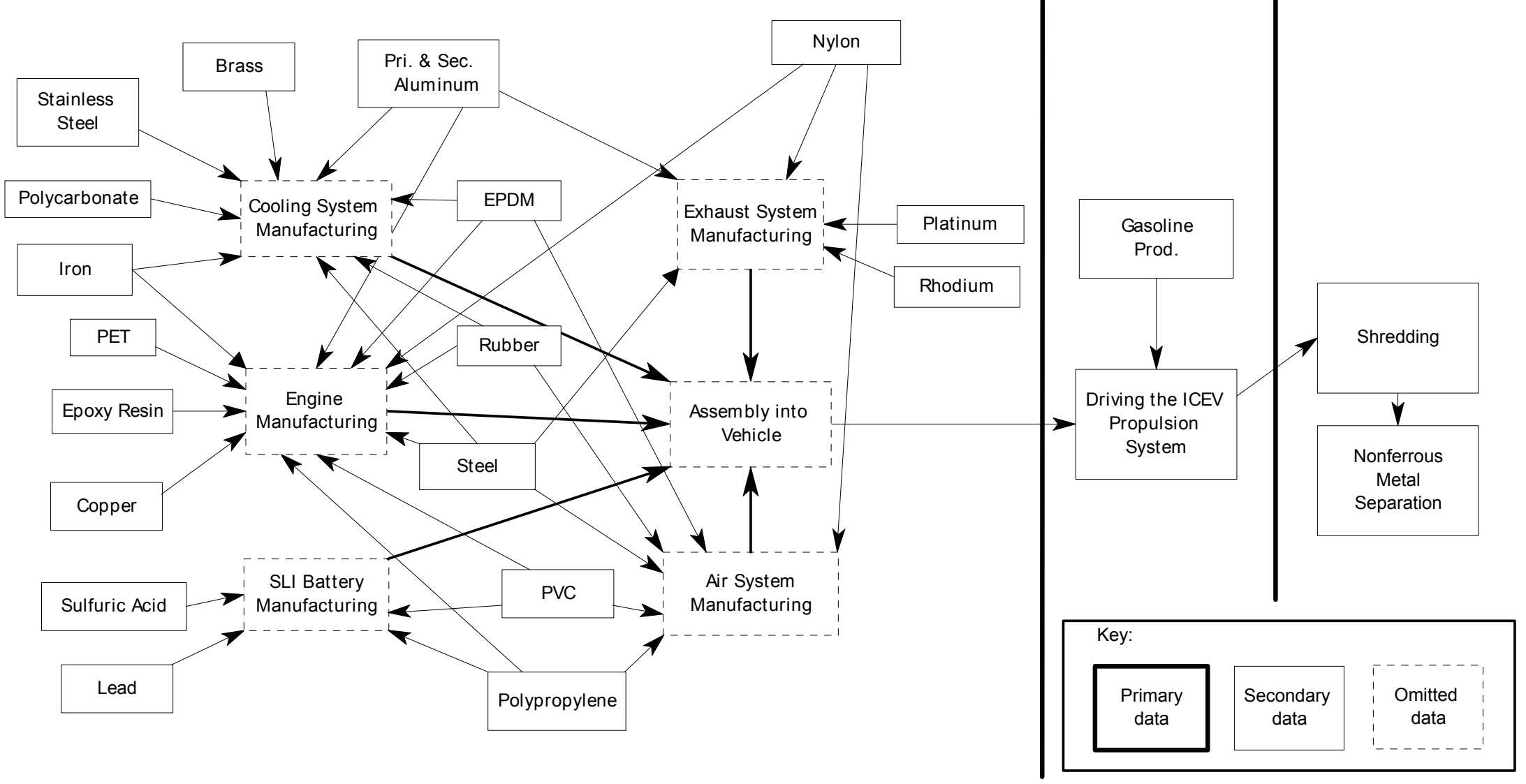

Figure 3.24. The ICEV Propulsion System Profile 
CRADLE TO GATE

(Extraction, Materials Processing \& Manufacturing)

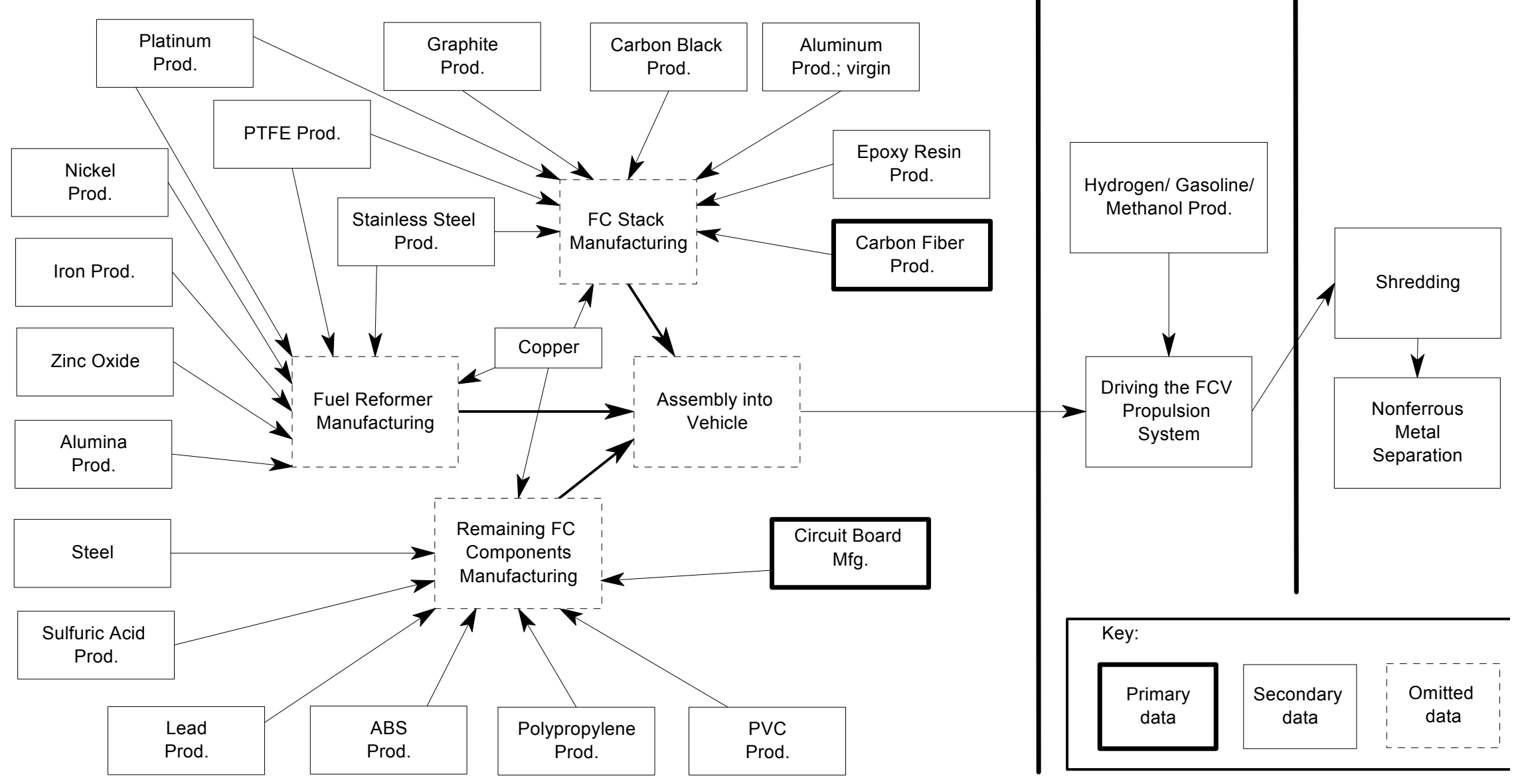

Figure 3.25. A Representation of the Multiple FCV Profiles 


\subsubsection{Long-Term Scenario}

An additional analysis was performed to take into account the long-term PNGV and DOE targets for FCVs. The reformed gasoline FCV was chosen to enact these changes since this particular vehicle (of the ones analyzed in this assessment) appears to be the most likely to be used first, due to gasoline's already existing infrastructure, the fact that some American automobile manufacturers are reluctant to use methanol (SAE 2001), and that a fair amount of opposition exists to methanol's use (SAE 2001).

This long-term scenario analysis focused on two aspects of the fuel cell system: the total fuel cell system weight and the amount of platinum in the fuel cell stack. Accordingly, the following changes were made to the RFCV-gas inventory breakdown to come up with a new breakdown for RFCV-gas-LT.

1) Within the fuel cell stack, the platinum amount was reduced from about 181 grams to 20 grams, a value close to the PNGV target of 10 grams and a value expected to be achievable by many within the fuel cell industry.

2) Also within the fuel cell stack, the weight of the bipolar plates was cut in half, from about $128 \mathrm{~kg}$ to $64 \mathrm{~kg}$, based on the knowledge that newer materials are already being used (e.g., high production Grafoil, a "soft, natural graphite material") (SAE 2001)."

3 ) In the fuel cell reformer, the system weight was reduced by $40 \%$. This was done due to information found that suggests that the reformer system itself will most likely be reduced as a whole versus individual materials or components being reduced in weight. One source cited a $50 \%$ reduction in the reformer weight, in going from the previous generation to the next (PR Newswire 2000).

4) In the balance-of-plant (BOP) for the fuel cell system (components that are not in the fuel cell stack or reformer but are still part of the fuel cell system), the number of startup batteries was reduced from 6 to 1 , for a weight reduction of about $70 \mathrm{~kg}$. The batteries were accounted for primarily by the materials lead, sulfuric acid and polypropylene.

5) In reducing the vehicle weight by about $220 \mathrm{~kg}(12 \%)$, the RFCV-gas-LT fuel efficiency was increased by about $8.5 \%$ from the original gas-reformed FCV, from $53.2 \mathrm{mpg}$ to $57.7 \mathrm{mpg}$. The increase was calculated using the relationship that a $10 \%$ reduction in vehicle weight would incur an approximate $7 \%$ increase in fuel efficiency. Though this relationship is true only for ICEV-based weight changes, without other information to accurately estimate the relationship for FCVs, it was used as a surrogate. This facilitated calculating the reduced quantity of gasoline needed over the lifetime. Also, the use stage emissions and downstream EOL processing were reduced to reflect the alterations made to the vehicle.

The detailed materials breakdown created for the four different vehicle configurations is provided in Table 3.18 .

\footnotetext{
I In a discussion with an employee of a leading fuel cell research and manufacturing company, it was learned that the $50 \mathrm{~kW}$ PEM fuel cell systems they are currently developing contain, on average, 20 grams of platinum.

$\mathrm{m}$ It should also be noted that in using Grafoil, if less materials processing is required, the overall life-cycle burdens should be reduced.
} 


\begin{tabular}{|c|c|c|c|c|}
\hline Table 3.18. Materials Breakdow & the Fuel & ell Vehic & Assessment & \\
\hline Material & & Quanti & (kg) & \\
\hline & ICEV & H2FCV & RFCV & RFCV-LT \\
\hline Plastics & & & & \\
\hline Polyurethane & 35 [ & 35 & 35 & 35 \\
\hline Polyvinyl Chloride (PVC) & 20 & 23.7 & 23.7 & 23.7 \\
\hline Polyethylene & 6.2 & 6.2 & 6.2 & 6.2 \\
\hline Acrylonitrile Butadiene Styrene (ABS) & 11.1 & 17.7 & 17.7 & 17.7 \\
\hline Polyethylene Terephthalate (PET) & 2.2 & 1.9 & 1.9 & 1.9 \\
\hline Polystyrene (PS) & 1.1 & 1.1 & 1.1 & 1.1 \\
\hline Epoxy Resin & 0.8 & 0.6 & 0.6 & 0.6 \\
\hline Polyamide 66 (nylon 6,6) & 11.9 & 8.2 & 8.2 & 8.2 \\
\hline Polypropylene (PP) & 26.6 & 31.5 & 31.5 & 26.8 \\
\hline Ethylene Propylene Diene Monomer (EPDM) & 10.1 & 7.9 & 7.9 & 7.9 \\
\hline Polycarbonate (PC) & 5.4 & 5.2 & 5.2 & 5.2 \\
\hline Vinyl Acetate & 0 & 41.5 & 41.5 & 20.7 \\
\hline Nonferrous Metals & & & & \\
\hline Virgin Aluminum & 25.3 & 44.1 & 44.1 & 44.1 \\
\hline Recycled Aluminum & 71 & 72.7 & 72.7 & 72.7 \\
\hline Lead & 13 & 40.9 & 40.9 & 7.9 \\
\hline Copper & 24.8 & 68.3 & 135.9 & 108.9 \\
\hline Zinc & 2.02 & 0.64 & 0.64 & 0.64 \\
\hline Chromium & 4.3 & 4.8 & 19.5 & 13.6 \\
\hline Nickel & 0.95 & 1.09 & 15.01 & 9.44 \\
\hline Aluminum Oxide (Alumina) & 0.27 & 0.27 & 22.97 & 13.89 \\
\hline $\operatorname{Tin}(\mathrm{Sn})$ & 0.07 & 0.07 & 0.07 & 0.07 \\
\hline Tungsten & 0.01 & 0.01 & 0.01 & 0.01 \\
\hline Silver & 0.003 & 0.003 & 0.003 & 0.003 \\
\hline Platinum & 0.0015 & 0.181 & 0.208 & 0.037 \\
\hline Rhodium & 0.0003 & 0 & 0 & 0 \\
\hline Ferrous Metals & & & & \\
\hline Simulated Iron & 155 & 55.6 & 72.3 & 65.6 \\
\hline BOF Hot Rolled Steel & 126 & 126 & 126 & 126 \\
\hline BOF Cold Rolled Steel & 475.1 & 453.5 & 516.1 & 491.1 \\
\hline EAF Hot Rolled Steel & 211.2 & 182.1 & 182.1 & 182.1 \\
\hline Ferrite & 1.5 & 1.5 & 1.5 & 1.5 \\
\hline Fluids & & & & \\
\hline Water & 9 & 9 & 9 & 9 \\
\hline Ethylene Glycol & 4.3 & 0 & 0 & 0 \\
\hline Engine Oil & 3.5 & 0 & 0 & 0 \\
\hline Other Materials & & & & \\
\hline Rubber & 103.5 & 101 & 101 & 101 \\
\hline Glass & 42 & 42 & 42 & 42 \\
\hline Paper & 0.2 & 0.2 & 0.2 & 0.2 \\
\hline Carpeting (assumed Nylon 6,6) & 11 & 11 & 11 & 11 \\
\hline Sulfuric Acid & 2.2 & 33.9 & 33.9 & 5.7 \\
\hline Graphite & 0.092 & 86.63 & 86.63 & 43.36 \\
\hline Carbon Black & 0 & 1.32 & 1.32 & 1.32 \\
\hline Carbon Fiber & 0 & 10.6 & 10.6 & 10.6 \\
\hline PWBs & 0 & 4.2 & 4.2 & 4.2 \\
\hline Total Mass of Materials Included in Assess & 1416.72 & 1532.11 & 1730.36 & 1520.96 \\
\hline Total Vehicle Mass & 1467.84 & 1583.27 & 1781.48 & 1562.28 \\
\hline Mass Percentage Included & $96.52 \%$ & $96.77 \%$ & $97.13 \%$ & $97.36 \%$ \\
\hline
\end{tabular}




\subsubsection{Fuel Cell Vehicle Results}

The results obtained using the Life-Cycle Design Toolkit for analyzing the profiles compared in this assessment are presented and discussed in this section.

For this assessment, the baseline ICEV was a mid-sized Taurus class passenger car weighing about $1468 \mathrm{~kg}$, without the fuel tank system and its contents (i.e., gasoline). The total mass of components in the ICEV that would most likely have to be replaced in order to equip the vehicle with a fuel cell-based propulsion system was approximately $277 \mathrm{~kg}$. These components are listed in Section 3.5.2. The total mass of the fuel cell system with reformer was estimated to be about $590 \mathrm{~kg}$ (371 kg for the long-term case), while the system without reformer was $392 \mathrm{~kg}$.

The specifications of the five vehicles compared are provided in Table 3.19.

\begin{tabular}{|l|r|r|r|r|r|}
\hline \multicolumn{6}{|c|}{ Table 3.19. Profiles Evaluated for the Fuel Cell Vehicle Assessment } \\
\hline & ICEV & H2FCV & $\begin{array}{l}\text { RFCV- } \\
\text { MeOH }\end{array}$ & $\begin{array}{l}\text { RFCV- } \\
\text { gas }\end{array}$ & $\begin{array}{l}\text { RFCV- } \\
\text { gas-LT }\end{array}$ \\
\hline & 1,468 & 1,583 & 1,781 & 1,781 & 1,562 \\
\hline Mass of Vehicle (kg) & 277 & 392 & 590 & 590 & 371 \\
\hline Mass of switched subsystems (kg) & 1,191 & 1,191 & 1,191 & 1,191 & 1,191 \\
\hline Mass of other vehicle parts (kg) & $96.5 \%$ & $96.8 \%$ & $97.1 \%$ & $97.1 \%$ & $97.4 \%$ \\
\hline $\begin{array}{l}\text { Percent total mass accounted for } \\
\text { kg) }\end{array}$ & Gasoline & Hydrogen & Methanol & Gasoline & Gasoline \\
\hline Fuel & 26.6 & 79.8 & 61.2 & 53.2 & 57.7 \\
\hline Fuel efficiency (mpgge) & 12,591 & 1,611 & 12,033 & 6,295 & 5,804 \\
\hline $\begin{array}{l}\text { Lifetime fuel consumed by vehicle } \\
\text { (kg) }\end{array}$ & & & & & \\
\hline
\end{tabular}

The vehicle mass in each of the FCV profiles - both with and without the reformer systemis higher than the baseline. This higher weight somewhat handicaps the otherwise much cleaner and more fuel efficient FCVs in their comparison with the baseline ICEV. The mass of other vehicle components, i.e., those that are not affected by the change in propulsion system, was assumed to remain the same in each case $(1,191 \mathrm{~kg})$. The fuel efficiencies of the FCVs, in mpgge, were derived from GREET 1.5a (Wang 2000a).

The lifetime quantity of fuel consumed (in $\mathrm{kg}$ ) by the hydrogen FCV is the lowest, followed by the two gasoline FCVs, while the methanol FCV and the ICEV have the highest lifetime fuel consumption and are roughly equal to each other.

The impact scores obtained by analyzing the five profiles in the LCD Toolkit are provided in Table 3.20. 


\begin{tabular}{|c|c|c|c|c|c|c|}
\hline Impact Category & Units & 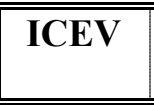 & H2FCV & $\begin{array}{l}\text { RFCV- } \\
\text { MeOH }\end{array}$ & $\begin{array}{c}\text { RFCV- } \\
\text { gas } \\
\end{array}$ & $\begin{array}{l}\text { RFCV- } \\
\text { gas-LT }\end{array}$ \\
\hline \multicolumn{7}{|l|}{ Impacts from Inputs } \\
\hline Nonrenewable resource use & (lbs) & 42,018 & 29,418 & 62,012 & 30,536 & 24,694 \\
\hline Renewable resource use & (lbs) & $\begin{array}{r}1,691,86 \\
6 \\
\end{array}$ & 388,903 & 429,857 & \begin{tabular}{|r|}
$1,177,08$ \\
1 \\
\end{tabular} & 943,690 \\
\hline Energy use & (MMBTUs) & 672 & 363 & 829 & 423 & 355 \\
\hline \multicolumn{7}{|l|}{ Impacts from Outputs } \\
\hline Global Warming & (lbs CO 2 -eq.) & 124,688 & 49,582 & 154,021 & 77,011 & 63,802 \\
\hline Ozone Depletion & (lbs CFC11-eq.) & 0.00065 & 0.00185 & 0.00276 & 0.00280 & 0.00185 \\
\hline Acidification & (lbs SO 2 -eq.) & 237 & 1,688 & 2,399 & 2,027 & 525 \\
\hline Smog & (lbs ethene-eq.) & 21.47 & 11.36 & 79.61 & 12.84 & 11.17 \\
\hline Particulates & (lbs PM) & 56.00 & 45.62 & 87.25 & 59.25 & 50.98 \\
\hline Odor (aesthetics) & $\left(\right.$ million $\left.\mathrm{m}^{3}\right)$ & 271.65 & 23.98 & 75.96 & 158.90 & 135.04 \\
\hline Solid waste landfill space & $\left(\mathrm{ft}^{3}\right)$ & 140.07 & 117.90 & 205.27 & 129.53 & 120.05 \\
\hline $\begin{array}{l}\text { Hazardous waste landfill } \\
\text { space }\end{array}$ & $\left(\mathrm{ft}^{3}\right)$ & 3.40 & 0.30 & 0.77 & 1.87 & 1.74 \\
\hline Eutrophication & $\begin{array}{l}\text { (lbs phosphate- } \\
\text { eq.) }\end{array}$ & 7.12 & 0.82 & 1.41 & 4.03 & 3.74 \\
\hline Water quality - BOD & (lbs BOD) & 27.28 & 0.40 & 4.22 & 13.87 & 12.77 \\
\hline Water quality - TSS & (lbs TSS) & 148.89 & 13.50 & 29.41 & 77.92 & 71.10 \\
\hline
\end{tabular}

Notes: Bold indicates lowest impact score.

The hydrogen FCV has the lowest environmental impacts in most of the impact categories evaluated (9 out of 14), mainly because of zero air emissions from driving and the lowest total lifetime quantity of fuel (hydrogen) consumed during use. The RFCV-gas-LT wins in 3 of the remaining categories (nonrenewable resource use, energy use, and smog formation) because of its lighter-weight reformer system and reduced lifetime fuel requirement, as compared to the other two reformer-based FCVs. Between the RFCV-MeOH and RFCV-gas, the only differences are in the Use stage (which includes Fuel Production and Fuel Use). The higher impacts for the methanol FCV in 7 of the 14 impact categories (including nonrenewable resource use, energy use, global warming, acidification, and particulates) are partly due to the much higher quantity of methanol required, as compared to the gasoline FCV, based on methanol's lower energy content, which is approximately half that of gasoline. Another reason for methanol's greater impacts is the methanol production process, which is more resource and energy intensive than that of gasoline, and also results in the generation of higher levels of global warming and acidification-causing emissions (namely, $\mathrm{CO}_{2}$, $\mathrm{SOx}$, and NOx), per kg of fuel produced.

In general, the high acidification impacts in the case of the RFCV-gas and RFCV-MeOH are from their high platinum content and, more specifically, the sulfur dioxide emissions associated with platinum production. The high ozone depletion impact scores for the FCVs are caused by Halon-1301 releases during the production of materials such as copper, platinum, nickel, and ABS, each of which is used in increased quantities in these vehicles, as compared to the ICEV. The ozone depletion scores, however, are quite insignificant in terms of actual values. 
The ratios of the impact scores for the ICEV vs. the hydrogen FCV are graphically represented in Figure 3.26. Among the 12 categories in which the ICEV is worse than the hydrogen FCV, the impact difference is the largest for water quality (BOD). Of the two remaining categories in which the ICEV turns out to be better, the impact difference between the two vehicles is the largest for acidification.

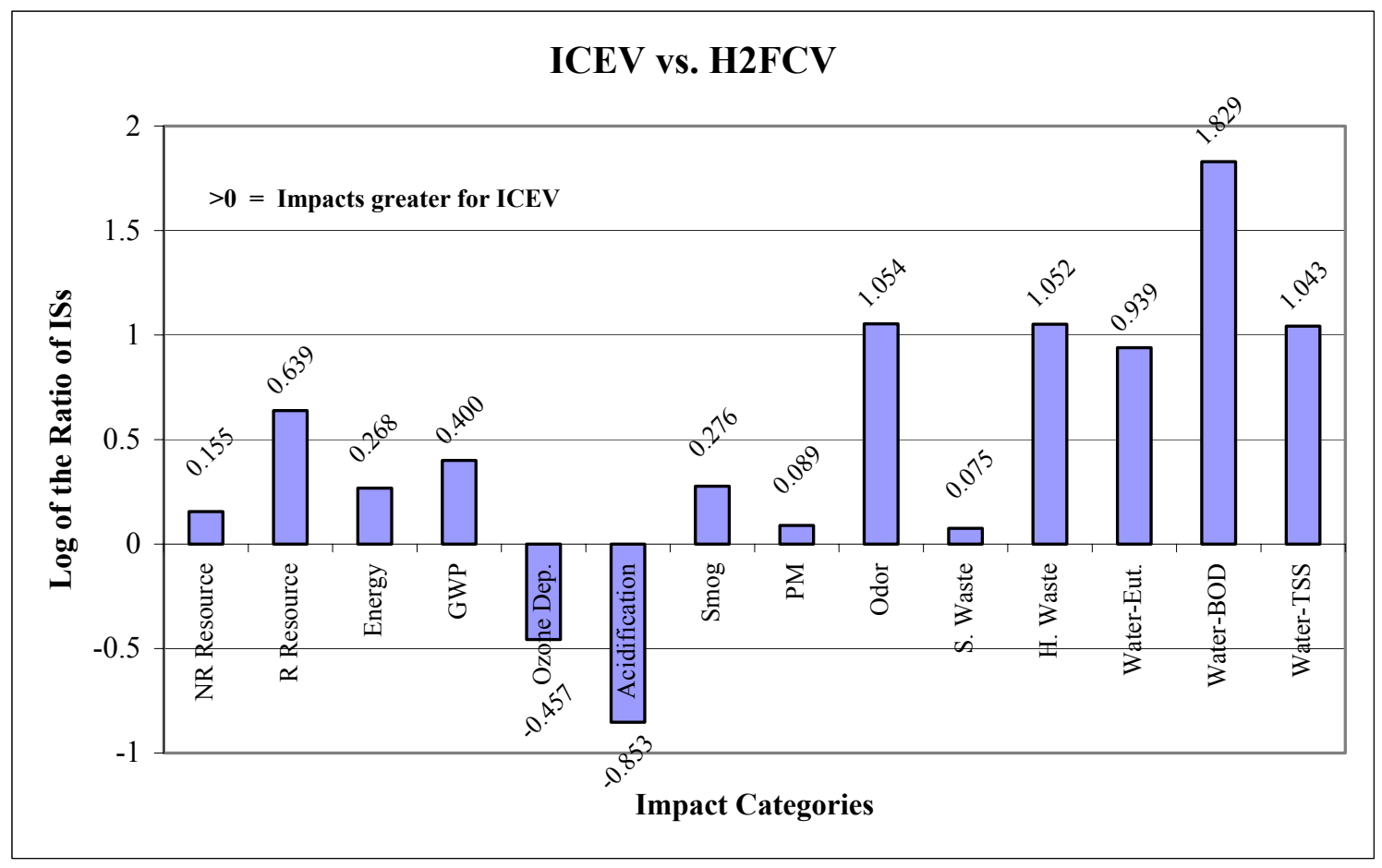

Figure 3.26. FCVs - ICEV vs. H2FCV Comparison

The overall picture remains the same for the comparison between the ICEV and the RFCVgas, as shown in Figure 3.27; however, the extent of the differences is reduced in categories where the ICEV has greater impacts, and magnified where the RFCV-gas has greater impacts.

When the ICEV is compared to the RFCV-gas-LT (Figure 3.28), the impact score in one category (particulate matter) switches from being better for the ICEV to being better for the RFCV-gas-LT. This change results from the reduction in platinum content in the long-term scenario (from 200 grams in the RFCV-gas to 20 grams in the RFCV-gas-LT), which accounts for $62 \%$ of the reduction in the particulate matter impact score. The ratios of the remaining scores reduce where the RFCV-gas previously had higher scores and increase where the ICEV previously had higher scores. In going from the ICEV to the RFCV-gas-LT, 12 of the 14 impact categories show reductions in the range of 9\% (PM) to 53\% (water quality - BOD), with most of the reductions between $40 \%$ and $50 \%$. However, two impact categories show increases in going to the RFCV-gas-LT, ozone depletion and acidification, where about $185 \%$ and $122 \%$ increases are seen, respectively. These increases, though, are still a significant improvement as compared to the RFCV-gas profile. 


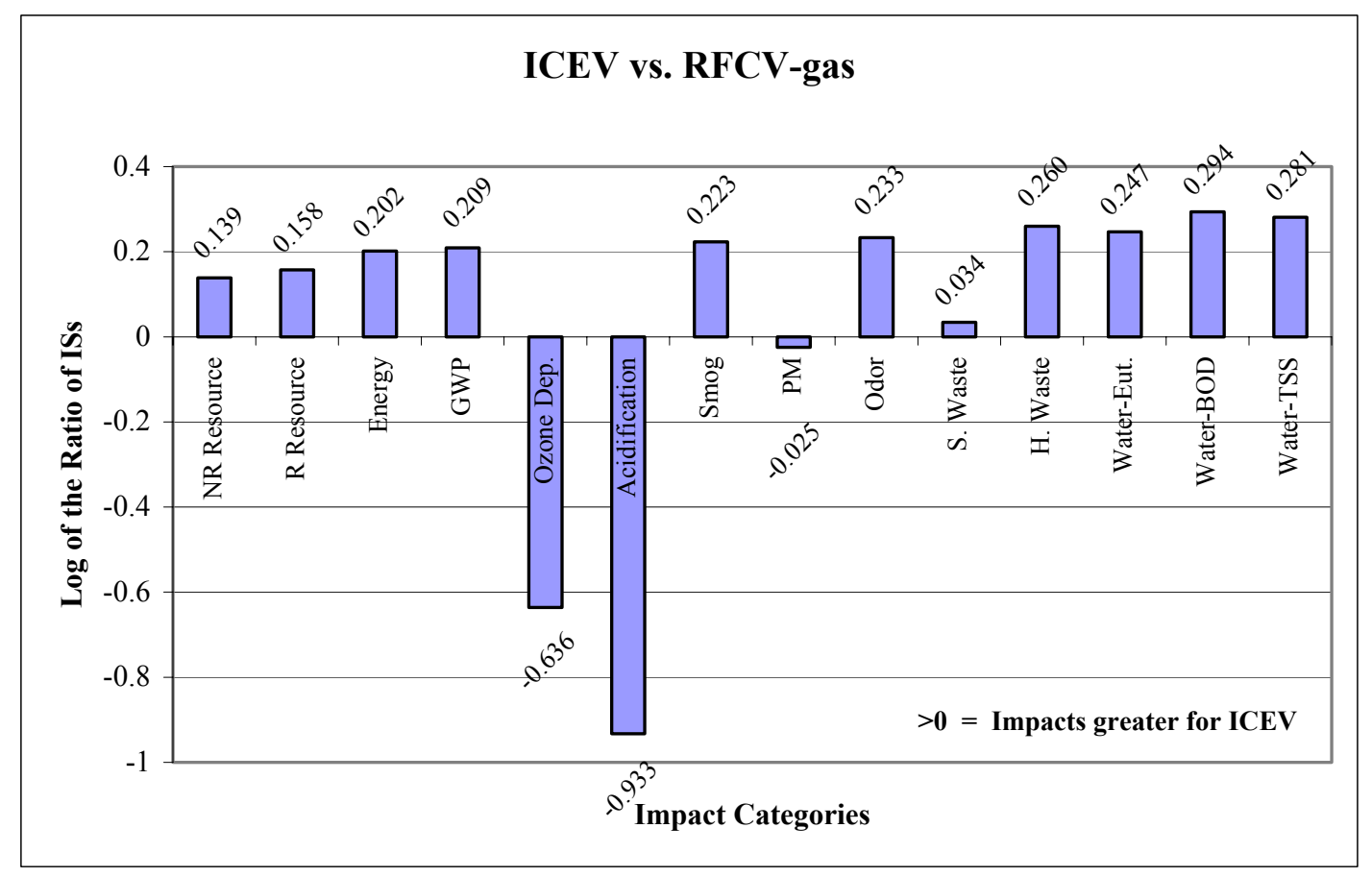

Figure 3.27. FCVs - ICEV vs. RFCV-gas Comparison

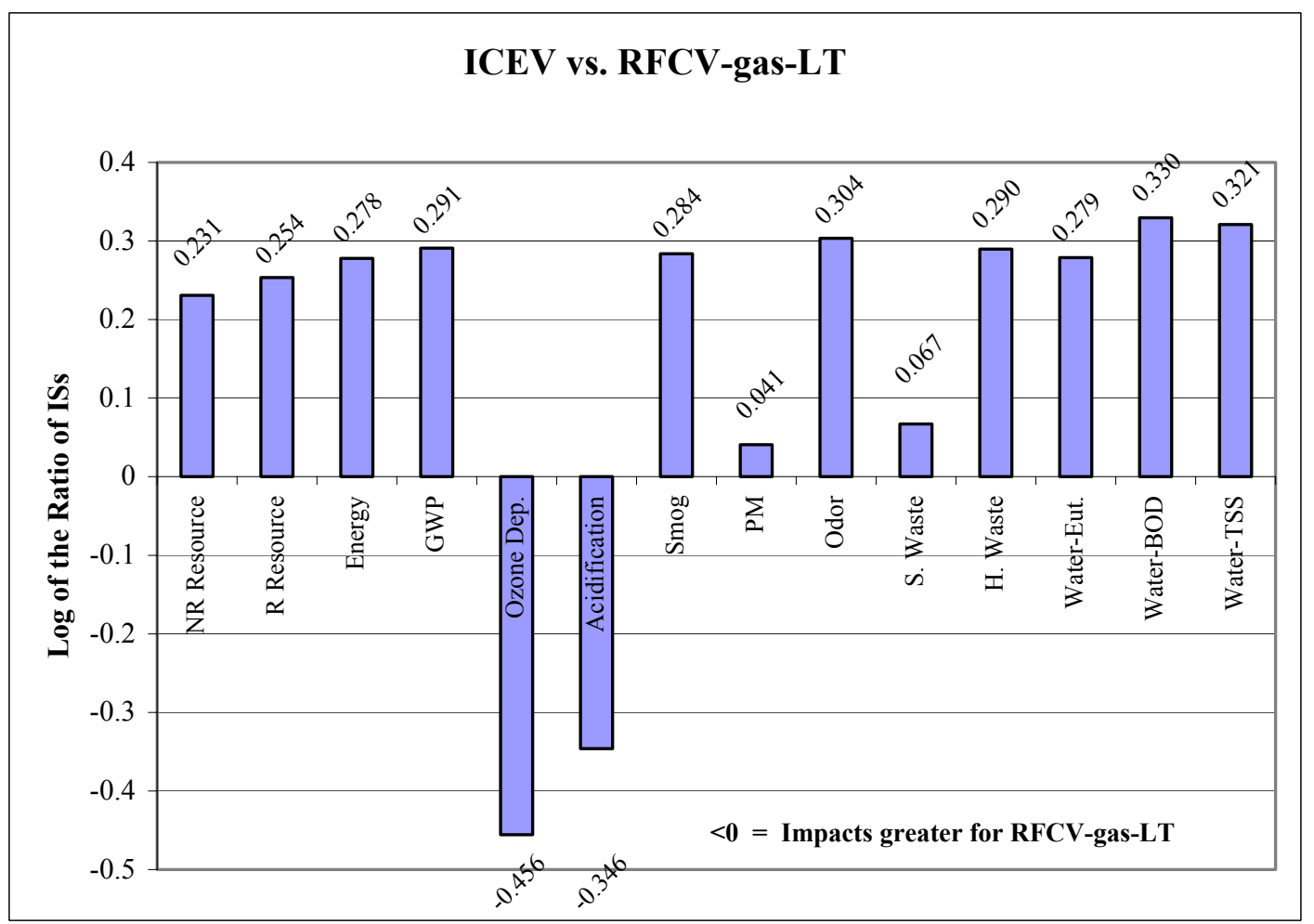

Figure 3.28. FCVs - ICEV vs. RFCV-gas-LT Comparison 
In the comparison of the ICEV and the methanol FCV (Figure 3.29), the ICEV has greater impacts in 6 of the 14 impact categories evaluated, while the methanol FCV has greater impacts in the remaining eight. The methanol FCV loses to the ICEV in a number of impact categories in which the RFCV-gas was better than the ICEV (namely, nonrenewable resource use, energy use, GWP, smog formation, and solid waste landfill space) because of the higher quantity of methanol required, and the associated higher quantities of material resources, energy, and emissions associated with methanol production, as mentioned earlier.

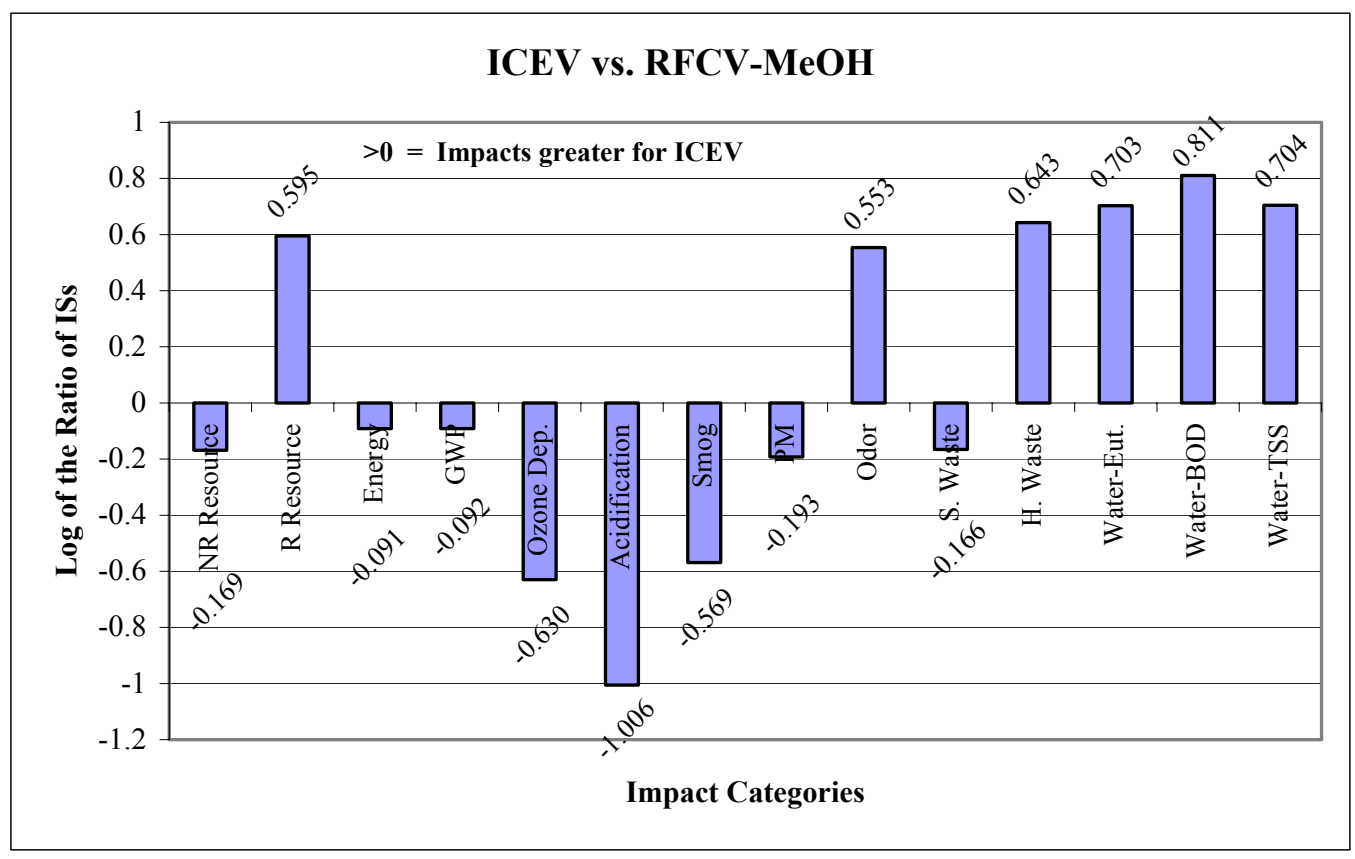

Figure 3.29. FCVs - ICEV vs. RFCV-MeOH Comparison

In the comparison of RFCV-MeOH to RFCV-gas (Figure 3.30), the overall results are very similar to the RFCV-MeOH to ICEV except that the ozone depletion impact category switches from being worse for the RFCV-MeOH to better. The main reason for this is that the ozone depletion score for the RFCV-gas ( $0.0028 \mathrm{lbs}$ CFC-11 equivalents) is over four times worse than the ozone depletion score for the ICEV (0.00065 lbs CFC-11-equivalents).

The reductions in weight and platinum content of the RFCV-gas-LT improve the environmental profile considerably (Figure 3.31). On a percentage basis, all the scores except one decrease in the range of $7 \%$ (solid and hazardous waste landfill space and eutrophication) to $34 \%$ (ozone depletion), with most being between $13 \%$ and $20 \%$. However, the extent of the difference is much more pronounced in the case of acidification (which decreased by $74 \%$ ), due to the extent of reduction in platinum quantity in going to the long-term scenario (i.e., from about 181 grams to 20 grams). Platinum production results in the generation of sulfur oxides responsible for increased acidification potential. 


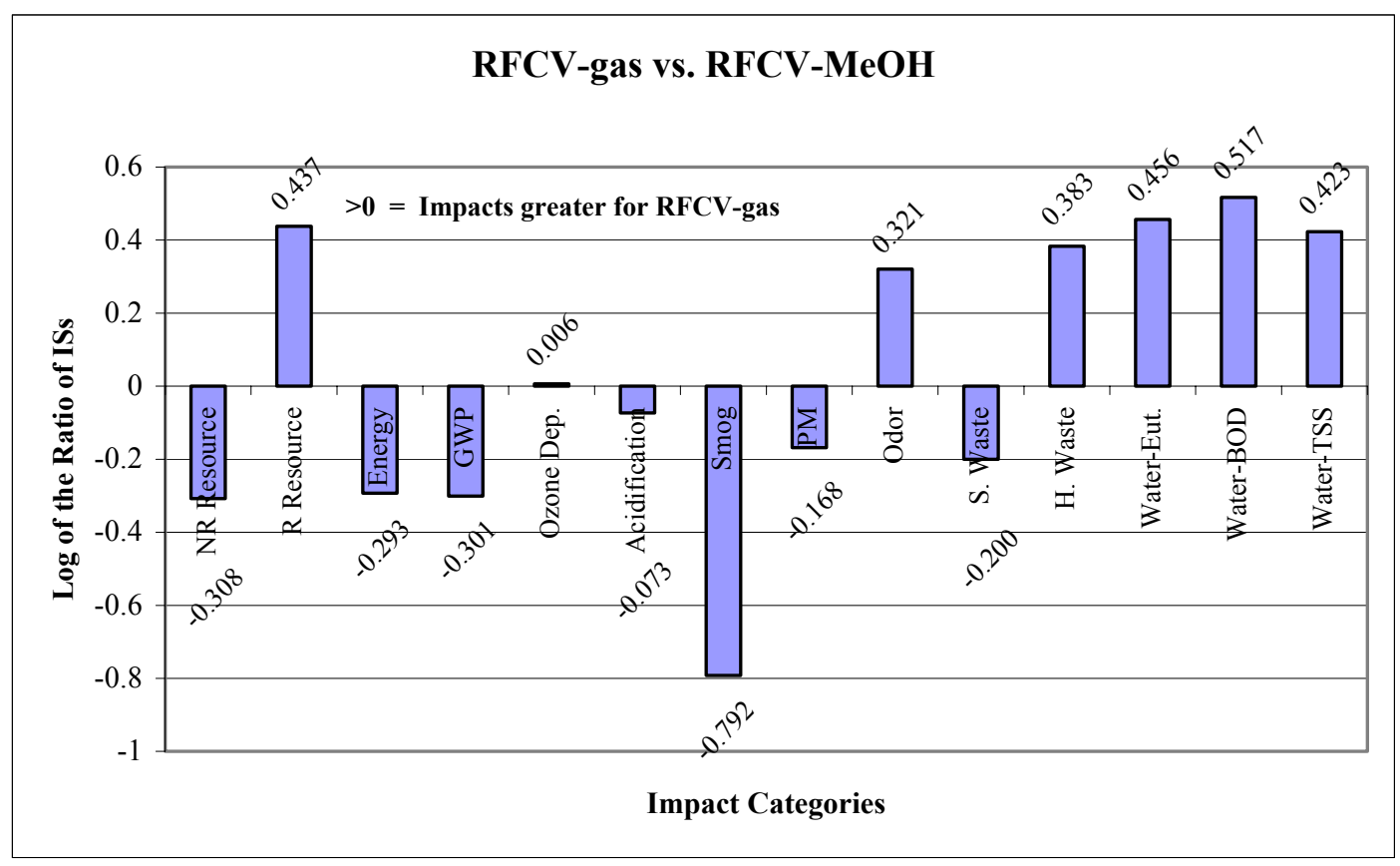

Figure 3.30. FCVs - RFCV Comparison - Gas vs. MeOH

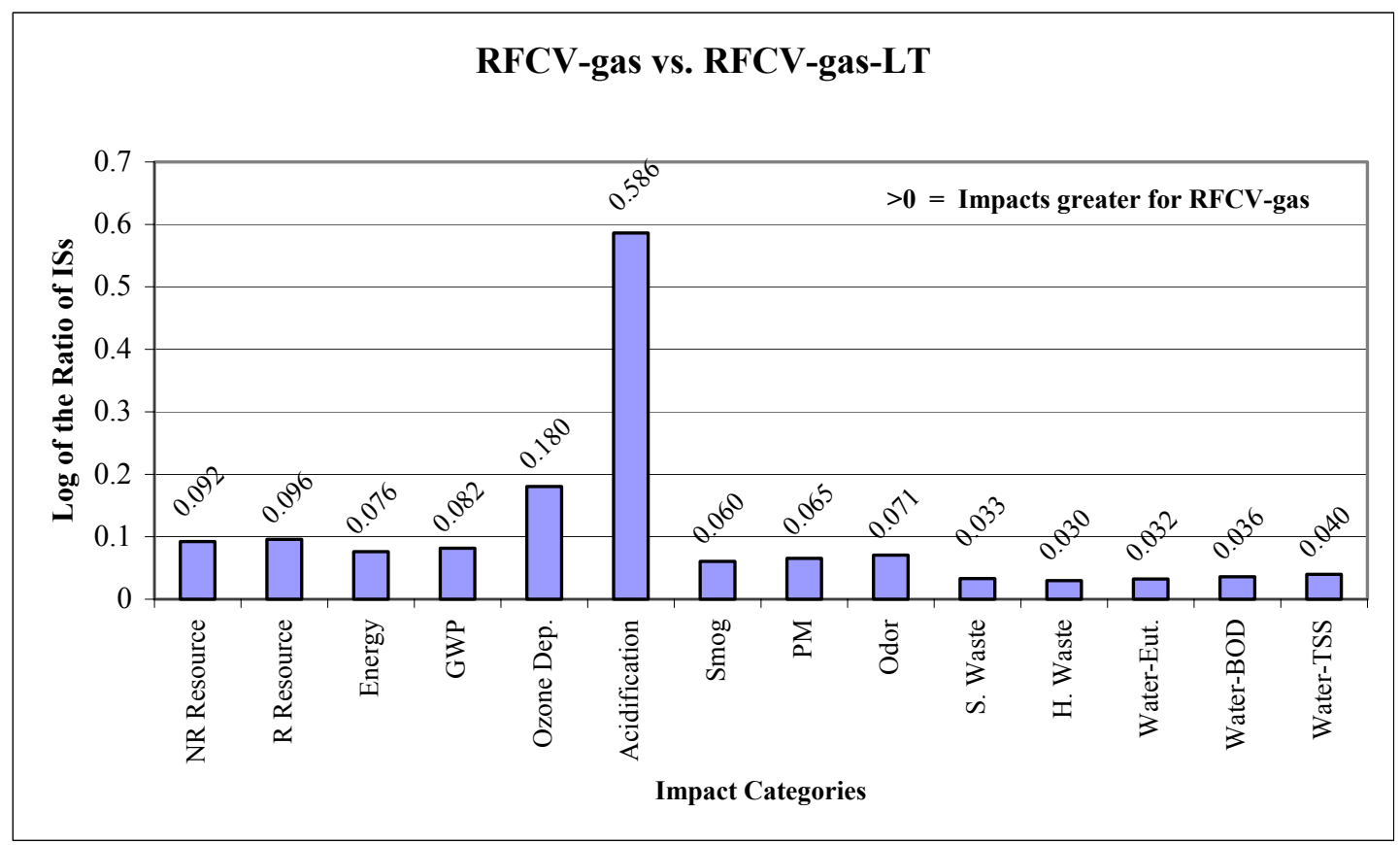

Figure 3.31. FCVs - Gas Comparison - gas vs. gas-LT 
In each of the four focus graphs shown (Figures 3.32 to 3.35), the methanol FCV has the highest impacts. In the nonrenewable resource use category, the two life-cycle stages that show up on the bar chart are Fuel Production and E\&MP. The ICEV is second to the methanol FCV in nonrenewable resource use impacts, with the RFCV-gas-LT having the lowest impacts.

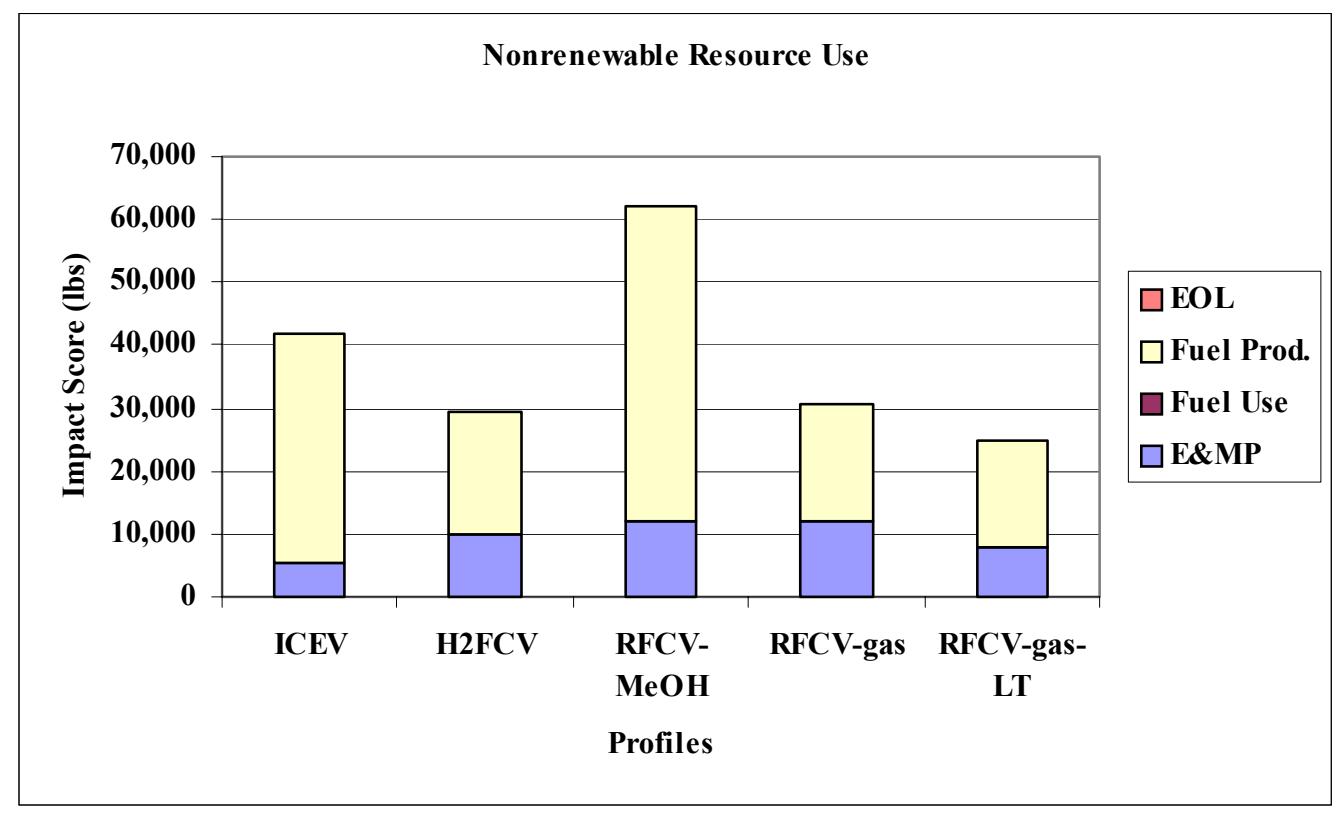

Figure 3.32. FCVs - Nonrenewable Resource Use

As may be observed from Table 3.21, fuel production in the Use stage tops the list for each of the five vehicles, accounting for as much as $84 \%$ of the nonrenewable resource impacts in the case of the ICEV. Platinum production in the E\&MP stage accounts for $9-10 \%$ in the case of the H2FCV and RFCV-gas, but does not figure in the top three for either the RFCV-gas-LT, due to the considerably reduced use of platinum in the vehicle, or the methanol FCV, where it is overshadowed by methanol production.

The patterns of use are similar for the energy use impacts (Figure 3.33). Although fuel use now shows up as a significant contributor, which was previously non-existent in the nonrenewable resource use category, the balance between the ICEV and the methanol FCV remains about the same. The fuel use energy in the case of methanol is much lower than for the ICEV, but the production of methanol is much more energy intensive than gasoline.

The top contributor to Energy Use is Driving (or Fuel Use) in the case of the ICEV (77\%), RFCV-gas-LT (68\%), RFCV-gas (62\%), as well as the hydrogen FCV (50\%). For the methanol FCV, however, production of methanol turns out to be the top contributor $(46 \%)$, followed by Driving (27\%). (See Table 3.22.) 
Table 3.21. Nonrenewable Resource Use in the Fuel Cell Vehicle Assessment: Lifecycle Stage Scores and Biggest Contributors

\begin{tabular}{|c|c|c|c|c|c|}
\hline $\begin{array}{l}\text { Nonrenewable } \\
\text { Resource Use } \\
\text { (lbs) }\end{array}$ & E\&MP & $\begin{array}{c}\text { Use - } \\
\text { Fuel Use }\end{array}$ & $\begin{array}{c}\text { Use - } \\
\text { Fuel Prod. }\end{array}$ & EOL & Total \\
\hline ICEV & $5,370.04$ & 0 & $36,617.00$ & 30.94 & $42,017.97$ \\
\hline $\mathrm{H} 2 \mathrm{FCV}$ & $10,008.27$ & 0 & $19,373.60$ & 36.16 & $29,418.02$ \\
\hline RFCV-MeOH & $12,185.08$ & 0 & $49,782.74$ & 43.84 & $62,011.67$ \\
\hline RFCV-gas & $12,185.08$ & 0 & $18,307.05$ & 43.84 & $30,535.97$ \\
\hline RFCV-gas-LT & $7,777.80$ & 0 & $16,879.12$ & 37.40 & $24,694.32$ \\
\hline $\begin{array}{l}\text { Biggest } \\
\text { Contributors }\end{array}$ & $\begin{array}{l}\text { Life-cycle } \\
\text { Stage }\end{array}$ & $\overline{P \text { Process }}$ & $\overline{~ I n p u t ~}$ & $\begin{array}{l}\text { Score } \\
\text { (lbs) }\end{array}$ & $\begin{array}{l}\text { Percent } \\
\text { of Total }\end{array}$ \\
\hline ICEV - 1 & Use & Gasoline Prod. & Petroleum & $30,012.11$ & $71.4 \%$ \\
\hline ICEV - 2 & Use & Gasoline Prod. & Natural gas & $5,243.81$ & $12.5 \%$ \\
\hline $\mathrm{ICEV}-3$ & E\&MP & Steel Prod. & Iron ore & $1,643.96$ & $3.9 \%$ \\
\hline $\mathrm{H} 2 \mathrm{FCV}-$ & Use & $\begin{array}{l}\text { Natural Gas } \\
\text { Prod. }\end{array}$ & Natural gas & $13,272.25$ & $45.1 \%$ \\
\hline $\mathrm{H} 2 \mathrm{FCV}-2$ & Use & Hydrogen Prod. & Natural gas & $3,771.85$ & $12.8 \%$ \\
\hline $\mathrm{H} 2 \mathrm{FCV}-3$ & E\&MP & Platinum Prod. & Coal & $2,623.73$ & $8.9 \%$ \\
\hline RFCV-MeOH - 1 & Use & Methanol Prod. & Natura & $29,764.67$ & $48.0 \%$ \\
\hline RFCV-MeOH - 2 & Use & Methanol Prod. & Coal & $13,847.71$ & $22.3 \%$ \\
\hline RFCV-MeOH - 3 & Use & Methanol Prod. & Petroleum & $6,170.36$ & $10.0 \%$ \\
\hline RFCV-gas - 1 & Use & Gasoline Prod. & Petroleum & $15,004.86$ & $49.1 \%$ \\
\hline RFCV-gas - 2 & E\&MP & Platinum Prod. & Coal & $3,015.78$ & $9.9 \%$ \\
\hline RFCV-gas - 3 & Use & Gasoline Prod. & Natural gas & $2,621.70$ & $8.6 \%$ \\
\hline RFCV-gas-LT -1 & Use & Gasoline Prod. & Petroleum & $13,834.50$ & $56.0 \%$ \\
\hline RFCV-gas-LT -2 & Use & Gasoline Prod. & Natural gas & $2,417.21$ & $9.8 \%$ \\
\hline RFCV-gas-LT -3 & E\&MP & Steel Prod. & Iron ore & $1,687.86$ & $6.8 \%$ \\
\hline
\end{tabular}

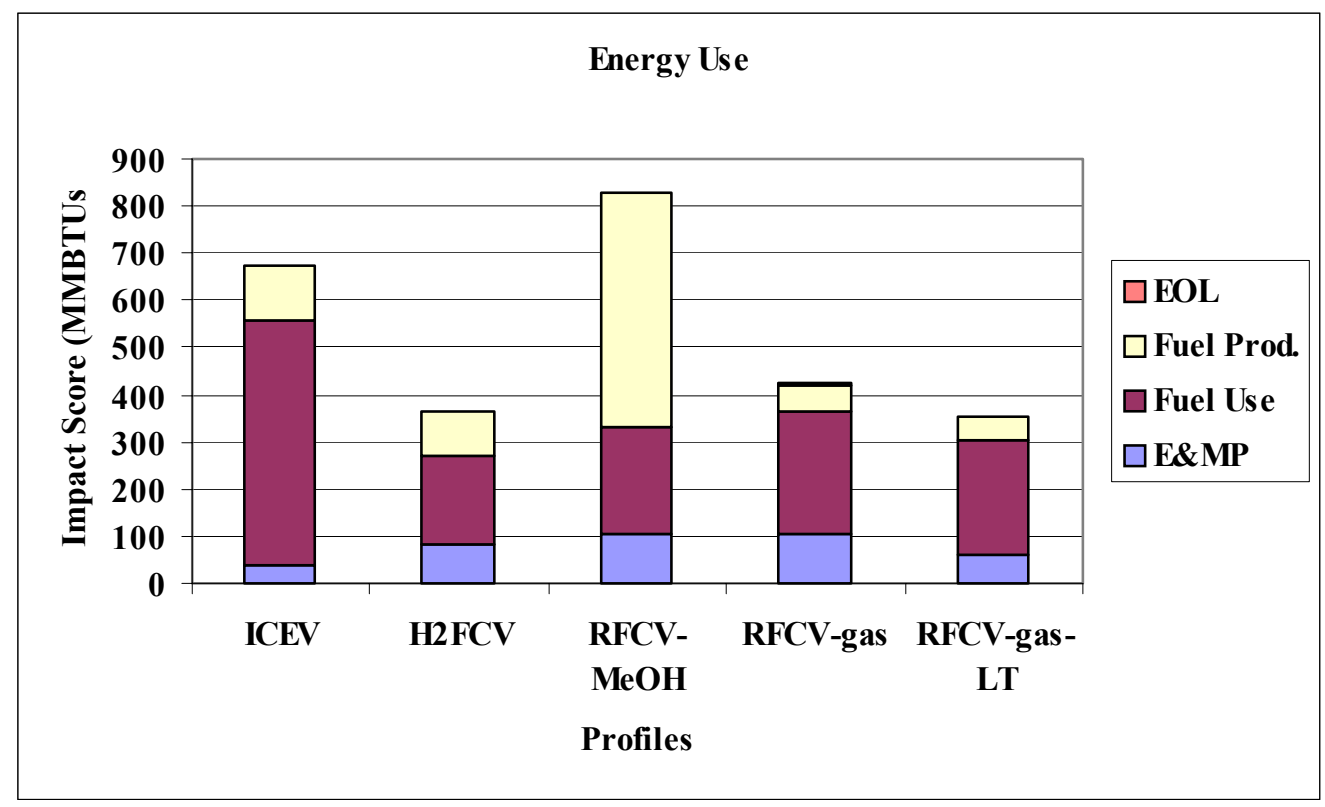

Figure 3.33. FCVs - Energy Use 


\begin{tabular}{|c|c|c|c|c|c|}
\hline \multicolumn{6}{|c|}{$\begin{array}{c}\text { Table 3.22. Energy Use in the Fuel Cell Vehicle Assessment: } \\
\text { Life-cycle Stage Scores and Biggest Contributors }\end{array}$} \\
\hline $\begin{array}{l}\text { Energy Use } \\
\text { (MMBTUs) }\end{array}$ & E\&MP & $\begin{array}{c}\text { Use - } \\
\text { Fuel Use }\end{array}$ & $\begin{array}{c}\text { Use - } \\
\text { Fuel Prod. }\end{array}$ & EOL & Total \\
\hline ICEV & 36.79 & 520.53 & 114.88 & 0.16 & 672.35 \\
\hline $\mathrm{H} 2 \mathrm{FCV}$ & 85.18 & 183.04 & 94.51 & 0.19 & 362.92 \\
\hline RFCV-MeOH & 104.72 & 226.31 & 498.15 & 0.23 & 829.40 \\
\hline RFCV-gas & 104.72 & 260.24 & 57.43 & 0.23 & 422.62 \\
\hline RFCV-gas-LT & 61.48 & 239.94 & 52.95 & 0.20 & 354.58 \\
\hline $\begin{array}{l}\text { Biggest } \\
\text { Contributors }\end{array}$ & $\begin{array}{l}\text { Life-cycle } \\
\text { Stage }\end{array}$ & Process & Input & $\begin{array}{c}\text { Score } \\
\text { (MMBTUs) }\end{array}$ & $\begin{array}{l}\text { Percent } \\
\text { of Total }\end{array}$ \\
\hline ICEV - 1 & Use & Driving & Gasoline & 520.53 & $77.4 \%$ \\
\hline ICEV - 2 & Use & Gasoline Prod. & Natural gas & 100.39 & $14.9 \%$ \\
\hline ICEV - 3 & Use & Gasoline Prod. & Coal & 13.01 & $1.9 \%$ \\
\hline $\mathrm{H} 2 \mathrm{FCV}-1$ & Use & Driving & $\begin{array}{l}\text { Compressed } \\
\text { hydrogen } \\
\text { gas }\end{array}$ & 183.04 & $50.4 \%$ \\
\hline $\mathrm{H} 2 \mathrm{FCV}-2$ & Use & Hydrogen Prod. & Natural gas & 72.16 & $19.9 \%$ \\
\hline $\mathrm{H} 2 \mathrm{FCV}-3$ & E\&MP & Platinum Prod. & Coal & 25.20 & $6.9 \%$ \\
\hline RFCV-MeOH - 1 & Use & Methanol Prod. & Natural gas & 246.31 & $29.7 \%$ \\
\hline RFCV-MeOH - 2 & Use & Driving & Methanol & 226.31 & $27.3 \%$ \\
\hline RFCV-MeOH - 3 & Use & Methanol Prod. & Coal & 133.02 & $16.0 \%$ \\
\hline RFCV-gas - 1 & Use & Driving & Gasoline & 260.24 & $61.6 \%$ \\
\hline RFCV-gas - 2 & Use & Gasoline Prod. & Natural gas & 50.19 & $11.9 \%$ \\
\hline RFCV-gas - 3 & E\&MP & Platinum Prod. & Coal & 28.97 & $6.9 \%$ \\
\hline RFCV-gas-LT - 1 & Use & Driving & Gasoline & 239.94 & $67.7 \%$ \\
\hline RFCV-gas-LT - 2 & Use & Gasoline Prod. & Natural gas & 46.27 & $13.1 \%$ \\
\hline RFCV-gas-LT - 3 & Use & Gasoline Prod. & Coal & 6.00 & $1.7 \%$ \\
\hline
\end{tabular}

The global warming impact category in Figure 3.34 follows the same pattern as energy use, except in the case of the hydrogen FCV. The GWP impacts from Fuel Use for the hydrogen FCV are zero, because no emissions were associated with driving the hydrogen-based vehicle. All the GWP impacts for the hydrogen FCV, therefore, are either from the production of materials that go into the vehicle or the production of hydrogen required to fuel it. In fact, more than 50\% of the GWP impacts for the hydrogen FCV are from emissions of global warming gases associated with hydrogen production.

The biggest contributors to global warming impacts for the ICEV and the gasoline FCVs (Table 3.23) are $\mathrm{CO}_{2}$ emissions from Driving. For the methanol and hydrogen FCVs, the biggest contributor is Fuel Production. There are no emissions associated with driving the hydrogen FCV, and the global warming emissions from driving the methanol FCV are less than those of the other vehicles. 


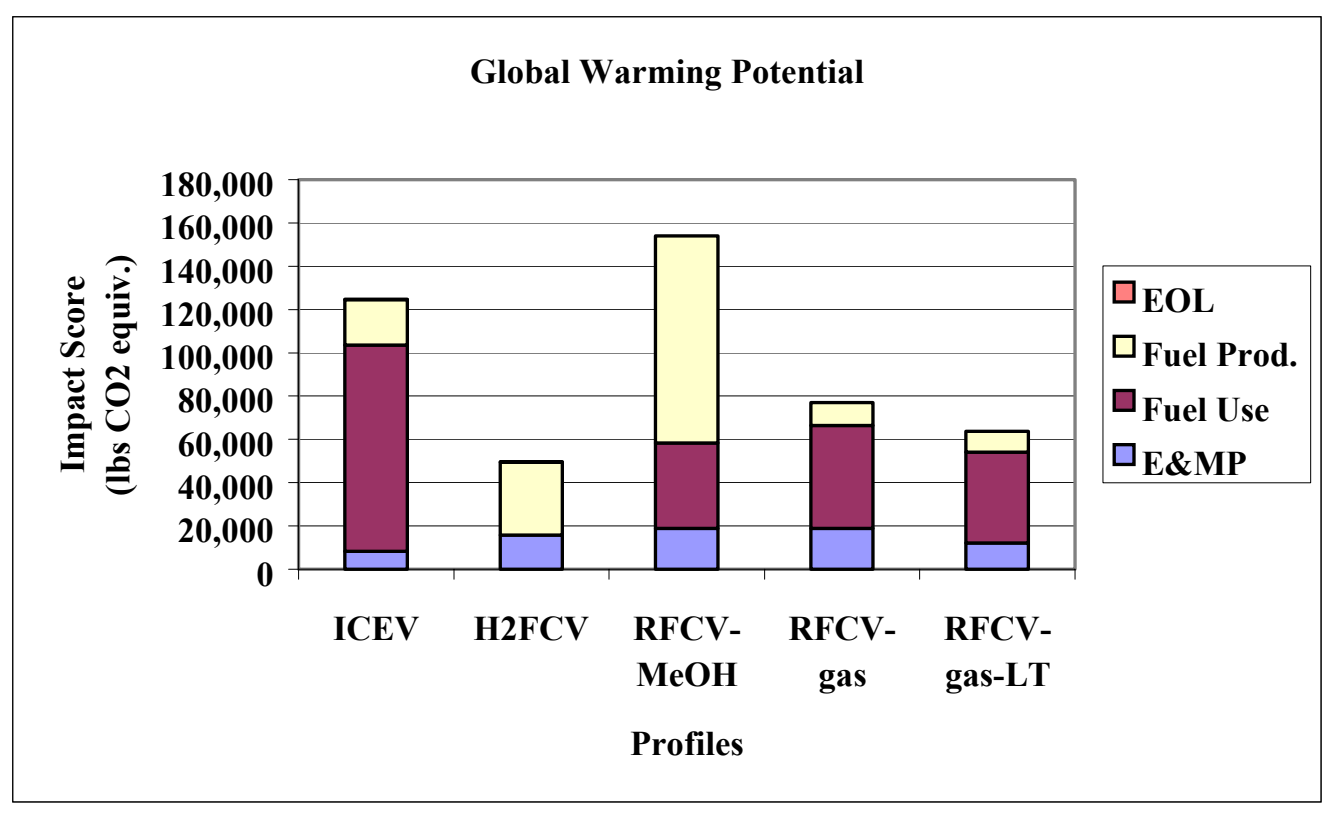

Figure 3.34. FCVs - Global Warming Potential

\begin{tabular}{|c|c|c|c|c|c|}
\hline $\begin{array}{l}\text { GWP } \\
\text { (lbs } \mathrm{CO}_{2} \text { equiv.) }\end{array}$ & E\&MP & $\begin{array}{c}\text { Use - } \\
\text { Fuel Use }\end{array}$ & $\begin{array}{c}\text { Use - } \\
\text { Fuel Prod. }\end{array}$ & EOL & Total \\
\hline ICEV & $8,317.39$ & $95,281.47$ & $21,019.42$ & 69.78 & $124,688.05$ \\
\hline $\mathrm{H} 2 \mathrm{FCV}$ & $15,694.17$ & 0 & $33,807.57$ & 80.48 & $49,582.22$ \\
\hline RFCV-MeOH & $18,772.21$ & $39,534.14$ & $95,618.36$ & 96.47 & $154,021.18$ \\
\hline RFCV-gas & $18,772.21$ & $47,633.49$ & $10,508.87$ & 96.47 & $77,011.05$ \\
\hline RFCV-gas-LT & $12,158.67$ & $41,869.23$ & $9,689.20$ & 84.80 & $63,801.89$ \\
\hline $\begin{array}{l}\text { Biggest } \\
\text { Contributors }\end{array}$ & $\begin{array}{l}\text { Life-cycle } \\
\text { Stage }\end{array}$ & Process & Output & $\begin{array}{c}\text { Score (lbs } \\
\mathrm{CO}_{2} \\
\text { equiv.) }\end{array}$ & $\begin{array}{c}\text { Percent of } \\
\text { Total }\end{array}$ \\
\hline ICEV - 1 & Use & Driving & $\mathrm{CO}_{2}$ & $95,209.24$ & $76.4 \%$ \\
\hline ICEV - 2 & Use & Gasoline Prod. & $\mathrm{CO}_{2}$ & $18,605.08$ & $14.9 \%$ \\
\hline ICEV - 3 & E\&MP & Steel Prod. & $\mathrm{CO}_{2}$ & $3,186.26$ & $2.6 \%$ \\
\hline $\mathrm{H} 2 \mathrm{FCV}-1$ & Use & Hydrogen Prod. & $\mathrm{CO}_{2}$ & $19,384.89$ & $39.1 \%$ \\
\hline $\mathrm{H} 2 \mathrm{FCV}-2$ & Use & $\begin{array}{l}\text { Natural Gas } \\
\text { Prod. }\end{array}$ & $\mathrm{CO}_{2}$ & $5,160.82$ & $10.4 \%$ \\
\hline $\mathrm{H} 2 \mathrm{FCV}-3$ & E\&MP & Platinum Prod. & $\mathrm{CO}_{2}$ & $5,135.98$ & $10.4 \%$ \\
\hline RFCV-MeOH -1 & Use & Methanol Prod. & $\mathrm{CO}_{2}$ & $85,283.46$ & $55.4 \%$ \\
\hline RFCV-MeOH -2 & Use & Driving & $\mathrm{CO}_{2}$ & $39,519.70$ & $25.7 \%$ \\
\hline RFCV-MeOH -3 & Use & Methanol Prod. & Methane & $9,878.92$ & $6.4 \%$ \\
\hline RFCV-gas - 1 & Use & Driving & $\mathrm{CO}_{2}$ & $47,619.04$ & $61.8 \%$ \\
\hline RFCV-gas - 2 & Use & Gasoline Prod. & $\mathrm{CO}_{2}$ & $9,301.80$ & $12.1 \%$ \\
\hline RFCV-gas - 3 & E\&MP & Platinum Prod. & $\mathrm{CO}_{2}$ & $5,903.43$ & $7.7 \%$ \\
\hline RFCV-gas-LT -1 & Use & Driving & $\mathrm{CO}_{2}$ & $41,856.53$ & $65.6 \%$ \\
\hline RFCV-gas-LT -2 & Use & Gasoline Prod. & $\mathrm{CO}_{2}$ & $8,576.27$ & $13.4 \%$ \\
\hline RFCV-gas-LT -3 & E\&MP & Steel Prod. & $\mathrm{CO}_{2}$ & $3,271.36$ & $5.1 \%$ \\
\hline
\end{tabular}


An additional note should be made here about methanol production. With regard to the production of methanol via natural gas reforming, the data used in this study (DEAM data) appear to have higher values for the consumption of energy and nonrenewable resources, and the generation of global warming gases than other published literature. In an attempt to show the differences, the following table (Table 3.24) and information are presented. To show some of the differences, the data were compared to GREET data (Wang, 2000b) and to data from a report prepared by $(\mathrm{S} \& \mathrm{~T})^{2}$ Consultants for Methanex Corporation ((S\&T) $)^{2}$ Consultants, Inc., 2000).

\begin{tabular}{|l|r|r|}
\hline \multicolumn{4}{|c|}{ Table 3.24. Comparison of GWP Scores from Different Data } \\
Sources
\end{tabular}

Converted from units of grams/mile to $\mathrm{lbs} / \mathrm{life}$.

The above table shows that the ICEV's total GWP impact score from this study appears to be in agreement with the corresponding scores from the other two data sources. In the case of the methanol FCV, however, this study results in a much higher GWP score (about 2-3 times higher) than the other two. As stated previously, LCA results are highly dependent on the data used, as is clearly evident from the above comparison. The higher values observed in this study for the methanol FCV's impact scores in the energy use, nonrenewable resource use, and GWP categories are directly attributable to the methanol production data used in this study.

The Acidification impacts are clearly dominated by the E\&MP stage (except in the case of the ICEV), as shown in Figure 3.35. The acidification impacts for the ICEV are much lower than for any other vehicle, with more than 50\% coming from Fuel Production. For each of the FCVs, on the other hand, the bulk of the acidification impacts come from platinum production in the E\&MP stage, contributing to the extent of $90 \%$ in the case of the hydrogen FCV. 


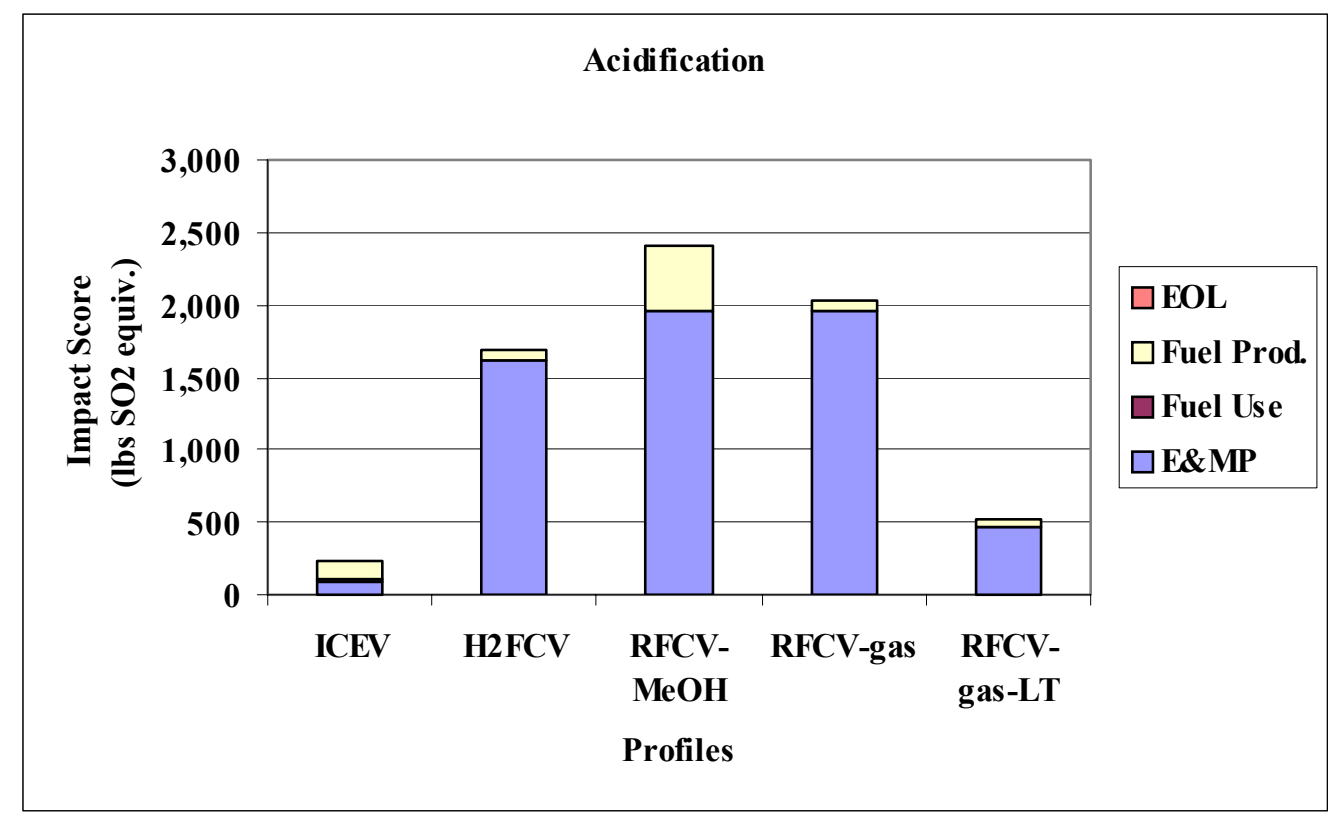

Figure 3.35. FCVs - Acidification

\begin{tabular}{|c|c|c|c|c|c|}
\hline \multicolumn{6}{|c|}{$\begin{array}{l}\text { Table 3.25. Acidification in the Fuel Cell Vehicle Assessment: } \\
\text { Life-cycle Stage Scores and Biggest Contributors }\end{array}$} \\
\hline $\begin{array}{l}\text { Acidification } \\
\text { (lbs } \mathrm{SO}_{2} \text { equiv.) }\end{array}$ & E\&MP & $\begin{array}{c}\text { Use - } \\
\text { Fuel Use }\end{array}$ & $\begin{array}{c}\text { Use - } \\
\text { Fuel Prod. }\end{array}$ & 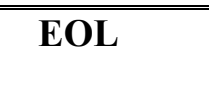 & Total \\
\hline ICEV & 83.91 & 15.74 & 136.60 & 0.52 & 236.76 \\
\hline $\mathrm{H} 2 \mathrm{FCV}$ & $1,621.61$ & 0 & 66.22 & 0.60 & $1,688.43$ \\
\hline RFCV-MeOH & $1,954.40$ & 3.70 & 440.42 & 0.72 & $2,399.24$ \\
\hline RFCV-gas & $1,954.40$ & 3.70 & 68.29 & 0.72 & $2,027.12$ \\
\hline RFCV-gas-LT & 458.58 & 3.26 & 62.97 & 0.63 & 525.43 \\
\hline $\begin{array}{l}\text { Biggest } \\
\text { Contributors }\end{array}$ & $\begin{array}{l}\text { Life-cycle } \\
\text { Stage }\end{array}$ & Process & $\overline{\text { Output }}$ & $\begin{array}{c}\text { Score } \\
\text { (lbs } \mathrm{SO}_{2} \\
\text { equiv.) }\end{array}$ & $\begin{array}{l}\text { Percent } \\
\text { of Total }\end{array}$ \\
\hline ICEV - 1 & Use & Gasoline Prod. & $\mathrm{SO}_{2}$ & 89.86 & $38.0 \%$ \\
\hline ICEV - 2 & Use & Gasoline Prod. & $\mathrm{NO}_{2}$ & 43.83 & $18.5 \%$ \\
\hline ICEV - 3 & Use & Driving & NOx & 15.74 & $6.6 \%$ \\
\hline $\mathrm{H} 2 \mathrm{FCV}-1$ & E\&MP & Platinum Prod. & SOx & $1,520.89$ & $90.1 \%$ \\
\hline $\mathrm{H} 2 \mathrm{FCV}-2$ & Use & US electric grid & $\mathrm{SO}_{2}$ & 27.89 & $1.7 \%$ \\
\hline $\mathrm{H} 2 \mathrm{FCV}-3$ & Use & $\begin{array}{l}\text { Natural Gas } \\
\text { Prod. }\end{array}$ & NOx & 25.47 & $1.5 \%$ \\
\hline RFCV-MeOH - 1 & E\&MP & Platinum Prod. & SOx & $1,748.15$ & $72.9 \%$ \\
\hline RFCV-MeOH - 2 & Use & Methanol Prod. & SOx & 284.89 & $11.9 \%$ \\
\hline RFCV-MeOH - 3 & Use & Methanol Prod. & NOx & 151.83 & $6.3 \%$ \\
\hline RFCV-gas - 1 & E\&MP & Platinum Prod. & SOx & $1,748.15$ & $86.2 \%$ \\
\hline RFCV-gas - 2 & E\&MP & Nickel Prod. & $\mathrm{SO}_{2}$ & 83.09 & $4.1 \%$ \\
\hline RFCV-gas - 3 & Use & Gasoline Prod. & $\mathrm{SO}_{2}$ & 44.92 & $2.2 \%$ \\
\hline RFCV-gas-LT - 1 & E\&MP & Platinum Prod. & SOx & 304.79 & $58.0 \%$ \\
\hline RFCV-gas-LT - 2 & E\&MP & Nickel Prod. & $\mathrm{SO}_{2}$ & 52.27 & $9.9 \%$ \\
\hline RFCV-gas-LT - 3 & Use & Gasoline Prod. & $\mathrm{SO}_{2}$ & 41.42 & $7.9 \%$ \\
\hline
\end{tabular}


The top acidification contributor to each of the three FCVs is platinum production, as mentioned earlier. Nickel production comes in as number two for the gasoline FCVs. Nickel is used in the fuel reformer as nickel catalyst, and is also a constituent of stainless steel, of which it comprises about $5 \%$ by mass. Another contributor is fuel production in each case. Further details may be found in Table 3.25.

\subsection{LCA CONCLUSIONS AND RECOMMENDATIONS}

This section summarizes the key findings and conclusions of the life-cycle assessments and makes recommendations for future work that would build upon and add further value to these assessments.

In the Exterior Body Panels assessment, CFRP has the lowest environmental impact scores in 9 out of 14 impact categories. This is mainly due to the fact that CFRP has the maximum weight reduction potential of all the materials evaluated (about $60 \%$ over steel), resulting in a much smaller quantity of material needed. In the remaining five impact categories, GFRP has the lowest scores in ozone depletion and particulates, while aluminum has the least impact in smog formation, and in two water quality impacts (eutrophication and total suspended solids).

The upstream processes involved in the production of automotive wrought aluminum (89\% virgin, $11 \%$ recycled) considered in this assessment increase its impacts significantly as compared to the other lightweighting materials. The aluminum production inventory included data that was based on a hydropower-heavy electric grid for the process electricity; using a U.S.-average grid would further increase aluminum's environmental "footprint". However, the environmental impacts of aluminum in automobile bodies can be greatly reduced by using a much larger quantity of recycled aluminum. This is possible if wrought aluminum is segregated by alloy, and alloying and trace element composition is carefully controlled (as is already done in the manufacture of virgin wrought aluminum) (Snedeker 2001).

Though UltraLight steel was not included as a potential candidate material in this assessment, it is certainly likely to be a major contender in the competition to replace conventional steel, from an environmental perspective. It is recommended that another study be conducted to specifically look into the life-cycle environmental impacts of UltraLight steel auto body (ULSAB) panels or UltraLight steel auto closures (ULSAC).

It is also recommended that part repairability should be examined more closely, as the need to completely replace (rather than repair a part) could significantly increase the life-cycle impacts of any material. It is already known that, in the majority of crash cases, steel and aluminum body panels can be repaired and repainted (depending on the extent of damage sustained by the panel in a crash). What is not known is the extent of damage that a CFRP or GFRP part can sustain before becoming unrepairable. Having to replace CFRP or GFRP parts may overshadow their environmental advantages as compared to repairing steel or aluminum. 
This evaluation did not fully assess and compare toxic chemical impacts among the materials. It is known that toxic gases are released during the production of carbon fiber. However, the quantity and type of release can vary depending on the polymer matrix the carbon fiber is to be used with. While this study did quantify the releases of toxic air emissions from carbon fiber production, it was not possible to compare them to those of other materials because similar data were not available for releases of toxic chemicals during production of those other materials. Any future analysis of these materials should include the toxicity impact categories to provide further insight into the effects of the use of such chemicals.

The previous discussion on the environmental preferability of CFRP was based on weight reductions achieved by replacing only the steel closure panels (weighing $220 \mathrm{lbs}$ ) with different lightweight materials. However, the monocoque analysis results show that more CFRP may not necessarily be better. By replacing a larger mass of steel with more CFRP, steel becomes environmentally preferable in 3 impact categories - ozone depletion, acidification, and smog formation. In all other categories, CFRP still has the lowest scores. Though the difference is minimal in the case of ozone depletion and acidification, the turnaround from the original results goes to show that certain environmental impacts might become significant when larger quantities of carbon fiber-based composites are used, due to the manufacturing impacts of CFRP.

Additionally, it should be noted that carbon fiber is being looked at for many different applications in automobiles, such as hydrogen tanks (SAE 2001), windshield wiper pillars (SAE 2000b), heat shields for brake cooling (SAE 2000), seats (SAE 2001) and front and rear bumpers (SAE 2001). As more potential weight savings are recognized through the use of carbon fiber throughout the automobile, and as the cost of manufacturing carbon fiber continues to fall and become more competitive with the other materials considered here, further analysis is warranted to find the associated environmental trade-offs.

It is recommended that in the future:

- An LCA be undertaken to look at the potential environmental savings that could be realized by increasing the recycled content of automotive wrought aluminum;

- Ultralight steel be included in future comparative LCAs to see what trade-offs are involved;

- The impacts from part repairability and replacability be included in material-based LCAs; and

- LCAs be undertaken to look at the other materials that carbon fiber and CFRP might replace as carbon fiber becomes more attractive as a lightweighting material.

The HEV Battery assessment revealed that the "current performance" LiIon battery's environmental profile has lower impact scores than its NiMH counterpart in almost all the impact categories evaluated (12 out of 14), in spite of the fact that 3.33 Lilon batteries are used over the life of the vehicle, versus $2 \mathrm{NiMH}$ batteries. One impact category in which NiMH scores lower than LiIon is solid waste landfill space, where the major contributor to LiIon's E\&MP stage is "slags and ash" from the production of aluminum, which was used in the current collectors $(\sim 2 \mathrm{~kg})$ and cell containers $(\sim 7.5 \mathrm{~kg})$ and assumed to be used in the battery casing $(\sim 1.7 \mathrm{~kg})$. 
In going to the "long-term" scenario, where the NiMH battery mass was reduced to become equal to that of the LiIon ( $40 \mathrm{~kg}$ ) and meet the PNGV goals for HEV power-assist battery weight, and both batteries were assumed to last 10 years, the overall conclusion remains unchanged: LiIon is still environmentally superior to $\mathrm{NiMH}$, based on the assumptions used in this analysis. LiIon-LT has lower scores in the same 12 categories, as compared to NiMH-LT.

The projected improvements in both batteries in the "long-term" scenario result in significant improvements in their overall environmental performance, as is observed in each of the impact categories evaluated. As an example, reductions of $40-50 \%$ are realized in the GWP impacts of both batteries, in going from the current performance scenario to the long-term.

There are other promising battery technologies currently under development for automotive use, such as lithium polymer, that warrant further assessment. Batteries are also being developed for use in hybrid vehicles that use fuel cell systems instead of internal combustion engines. In addition, to meet the increasing demand on vehicles' electrical systems, because of increased computerized control, provision of electronic security systems, growing emphasis on safety, and enhanced levels of on-board comfort and entertainment, the use of higher voltage systems is being contemplated. Batteries that can provide 36 or 42 volts are being developed, to either replace the existing 12-volt SLI battery, or as an auxiliary power source.

Thus, for future work, it is recommended that:

- Lithium polymer batteries be included in a comparison with LiIon and NiMH, with the analysis based more on primary data (from actual manufacturers) than secondary data;

- HEV batteries being developed by some auto manufacturers for use in fuel cell hybrid vehicles be evaluated for their environmental performance, compared either to conventional vehicles, or to ICE-based HEVs; and

- A study be conducted to see how the battery (SLI and hybrid) needs might change in going from a 12-volt to a 36 or 42-volt system for auxiliary power (and see how the batteries' environmental performance is affected by such a change).

In the Fuel Cell Vehicle assessment, the hydrogen FCV has the lowest impact scores in 9 of the 14 impact categories evaluated, mainly because of zero air emissions from driving and the lowest total lifetime quantity (by mass) of fuel (hydrogen) required during use. In 3 of the remaining 5 categories, namely, nonrenewable resource use, energy use, and smog formation, the long-term reformed gasoline FCV (RFCV-gas-LT) is the least environmentally burdensome. The ICEV has the lowest scores in only 2 impact categories - ozone depletion and acidification. The ozone depletion impacts are higher for the FCVs because of the releases of Halon-1301 associated with the production of increased quantities of copper, platinum, nickel, and ABS, while acidification is higher for the FCVs primarily due to the much higher quantities of platinum used in them.

Between the two FCVs with reformers (gasoline- and methanol-based), the only differences are in the Use stage (which includes Fuel Use and Fuel Production). The high impacts for the methanol FCV are due to the larger quantity of methanol required, given its energy content which is approximately half that of gasoline. Consequently, almost twice the quantity by mass 
of methanol is needed versus gasoline. Moreover, methanol production (based on the data used in this study) is also a big contributor to the methanol FCV's higher impacts, including global warming and acidification potential.

In the current technology scenario, the fuel cell + reformer system contributes significantly to the overall vehicle weight, with a combined mass of more than $600 \mathrm{~kg}$. As technology advances and contributes to reducing the system weight, which will help meet the PNGV target for specific power of $250 \mathrm{~W} / \mathrm{kg}$, the impacts from FCVs will be considerably reduced, as is evident from the impact scores obtained for the long-term case (RFCV-gas-LT).

The platinum used in the RFCV-gas and RFCV-MeOH is responsible for $80-90 \%$ of the acidification impacts for these vehicles (about $200 \mathrm{~g}$ of platinum are contained in the currenttechnology FCVs and approximately $20 \mathrm{~g}$ in the RFCV-gas-LT, as compared to $1.5 \mathrm{~g}$ in the ICEV). The primary contributor to acidification impacts is the emission of sulfur oxides (SOx).

In this assessment, only the reformed gasoline FCV profile was modified to create the RFCVgas-LT profile to show the effects of weight reduction and lowered platinum content in the long term. However, if similar changes were to be made to the $\mathrm{H} 2 \mathrm{FCV}$, it would only further decrease the hydrogen FCVs scores, most likely making it the overall leader looking at across-the-board differences compared to the ICEV's scores.

Before FCVs are put on the market, however, considerable work needs to be done on reducing the cost of fuel cell systems, which is currently very high. While the cost of a fuel cell system with reformer is presently estimated to lie in the range of $\$ 200-300$ per $\mathrm{kW}$, the PNGV target is $\$ 50 / \mathrm{kW}$ (Arthur D. Little, Inc. 2000). Work is already underway to reduce the overall weight of the system, bring down the platinum content to the target value of $0.2 \mathrm{~g}$ per peak $\mathrm{kW}$, and make improvements that would result in lower cost components, such as those in the membrane-electrode assembly (MEA), which currently contributes to a large part of the stack cost.

It is recommended that in the future:

- Various options for on-board hydrogen storage and fuel tank materials, which were excluded from this assessment, be examined; and

- Since this assessment assumed that each propulsion system would last the life of the vehicle, further work is necessary to determine the expected life, serviceability, and repairability of individual fuel cell system components, as their replacement frequency could greatly affect the environmental impacts.

Lastly, common to all three LCAs undertaken in this project, it is recommended that the generation of toxics be included in future assessments. In this effort, the toxics information provided by the secondary data used was inconsistent, and not enough time was allotted in the project to complete the toxics information. Future work should ensure that the toxics impacts are incorporated into the LCA to bring more of the environmental and human health effects into the comparisons. 



\section{REFERENCES}

\section{Chapter 1}

Das, Sujit, T. Randall Curlee and Susan M. Schexnayder. 1997. Materials Used in New Generation Vehicles: Supplies, Shifts, and Supporting Infrastructure. ORNL/TM-13491, Oak Ridge National Laboratory, Oak Ridge, TN, August.

Das, Sujit, T. Randall Curlee, Don W. Jones, Paul E. Leiby, Jonathon D. Rubin, Susan M. Schexnayder, David P. Vogt, and Amy K. Wolfe. 1999. Supporting Infrastructure and Acceptability Issues for Materials Used in New Generation Vehicles. ORNL/TM-13731, Oak Ridge National Laboratory, Oak Ridge, TN, March.

Das, Sujit, T. Randall Curlee, Stanton Hadley, Donald Jones, Bruce Tonn, Amy Wolfe, Gary Davis, Rajive Dhingra, Jonathon Overly, and Susan Schexnayder. 2000. Supporting Infrastructure and Acceptability Issues Associated with Two New Generation Vehicles: P2000 and ESX2. ORNL/TM-2000/91. Oak Ridge National Laboratory, Oak Ridge, Tennessee, May.

\section{Chapter 2}

APME (Association of Plastics Manufacturers of Europe). 2000. Life-cycle Analysis Reports. http://lca.apme.org/reports/htm/alphabetical.htm.

Automotive Engineering. 1992. "Recycling and the Automobile," October.

Berry, Bryan. 1992. “Automakers want to recycle all of the car," Iron Age (Feb.) pp. 28-29.

Boustead, I. 1997. Ecoprofiles of the European Plastics Industry. Technical paper of the Association of Plastics Manufacturers in Europe (APME).

Code of Federal Regulations, 2000, (various sections), http://www.access.gpo.gov/nara/cfr/cfr-table-search.html (assessed 2/28/01).

Curlee, Randall T., Sujit Das, Colleen G. Rizy, and Susan M. Schexnayder. 1994. Recent Trends in Automobile Recycling: An Energy and Economic Assessment. ORNL/TM12628, Oak Ridge National Laboratory, Oak Ridge, TN, March.

Das, Sujit, T. Randall Curlee, Stanton Hadley, Donald Jones, Bruce Tonn, Amy Wolfe, Gary Davis Rajive Dhingra, Jonathon Overly, and Susan Schexnayder. 2000. Supporting Infrastructure and Acceptability Issues Associated with Two New Generation Vehicles: P2000 and ESX2. ORNL/TM-2000/91. Oak Ridge National Laboratory, Oak Ridge, Tennessee.

Buchholz, Kami. 2000. "Supply/demand for recycling," Automotive Engineering International 108(6):38-40. 
Davis, G.A., L. Kincaid, M. Swanson, T. Schultz, J. Bartmess, B. Griffith, and S. Jones. 1994. Chemical Hazard Evaluation for Management Strategies: A Method for Ranking and Scoring Chemicals by Potential Human Health and Environmental Impacts, United States Environmental Protection Agency, EPA/600/R-94/177, September.

Ecobilan (Ecobalance) Group. 1999. Data for Environmental Analysis and Management (DEAM) life-cycle inventory database developed by the Ecobilan Group.

Environmental Defense 2000. http://www.scorecard.org/

Fisher, Michael M., and Frank E. Mark. 1999. "The Role of Plastics in Automotive Shredder Residue (ASR): Characterization and Environmental Assessment," (Warrendale, PA: SAE International, Technical Paper Series, 1999-01-0664). March.

Kincaid, Lori E., Catherine Wilt, Gary Davis, James Lumley, Fred Stoss, and Elithe Carnes. 1996. Vehicle Recycling and Disposal Policies in Industrialized and Developing Countries. (Knoxville, TN: University of Tennessee Center for Clean Products and Clean Technologies). Report prepared for American Automobile Manufacturers Association. June.

Klempner, Daniel, Kurt C. Frisch, B. Pokorski and Vahid Sendijarevic. 1999. "Characterization of Various ASR Streams" (Warrendale, PA: SAE International, Technical Paper Series 1999-01-0670). March.

Lanoir, D., et al.. 1997, "Physical \& Chemical Characterization of Automotive Shredder Residues," Waste Management \& Research: 15(3): 267-276.

Najor, Pamela. 2000, "EPA will not regulate coal wastes as hazardous under RCRA Subtitle C," Environment Reporter, 31(17):798. Washington, DC: Bureau of National Affairs.

National Mining Association. 2001. Summary of U.S. and World Mining Statistics. http://www.nma.org.

Peretz, Jean H. 1992, "Equity under and state responses to the Superfund Amendments and Reauthorization Act of 1986," Policy Sciences 25: 191-209.

Peretz, Jean H. 1997, "Waste management agenda setting: a case of incorrect problem definition?" Waste Management \& Research 16(3): 202-209.

Radimsky, Jan and Gin Watson. 1989. "Treatment Levels for Auto Shredder Waste," Sacramento, CA: State of California, Department of Health Services, Toxic Substances Control Division, Alternative Technology Section, Technical Support Document, June.

Rubber Manufacturers' Association. 2001 "Scrap Tires Facts and Figures," http://www.rma.org/scraptires/characteristics.html\#anchor135840 (accessed 06/01). 
Resource Conservation and Recovery Act of 1976, Public Law 94-580, 42 USC 6901-6992.

Superfund Amendments and Reauthorization Act of 1986, Public Law 99-499, 42 USC 96019675.

U.S. Environmental Protection Agency (EPA). 1991. PCB, Lead, and Cadmium Levels in Shredder Waste Materials: A Pilot Study. Office of Toxic Substances and Office of Solid Waste, EPA 560/5-90-008A). April.

U.S. Environmental Protection Agency (EPA). 1995a. National Capacity Assessment Report: Capacity Planning Pursuant to CERCLA Section 104(c)(9). EPA530-R-95-016, NTIS PB95-20672. http://www.epa.gov/epaoswer/hazwaste/tsds/capacity/cap_rpt.pdf (accessed 2/28/01).

U.S. Environmental Protection Agency (EPA). 1995b. Sector Notebook Project: Motor Vehicle Assembly Industry. September, http://es.epa.gov/oeca/sector/sectornote/pdf/motvehsn.pdf (accessed 2/26/01).

U.S. Environmental Protection Agency (EPA). 1997a. RCRA: Reducing Risk from Waste. Office of Solid Waste and Emergency Response, EPA530-K-97-004. September.

U.S. Environmental Protection Agency (EPA). 1997b. Waste Minimization Prioritization Tool (Beta Version 1.0): User's Guide and System Documentation (Draft). EPA530-R-97019. June.

U.S. Environmental Protection Agency (EPA). 1999. Executive Summary: The National Biennial RCRA Hazardous Waste Report (Based on 1997 Data). Office of Solid Waste and Emergency Response, EPA530-S-99-036.

U.S. Environmental Protection Agency (EPA). April 2000a. Environmental Fact Sheet: Municipal Solid Waste Generation, Recycling and Disposal in the United States: Facts and Figures for 1998. Office of Solid Waste and Emergency Response, EPA530-F-00024.

U.S. Environmental Protection Agency (EPA). 2000b. Toxic Release Inventory. $<$ http://www.epa.gov/enviro/html/tris/tris_query.html $>$, accessed 9/00 to 2/01.

U.S. Environmental Protection Agency (EPA). 2001 a. http://www.epa.gov/epaoswer/osw/Basifact.htm\#whois, accessed 2/28/01.

U.S. Environmental Protection Agency (EPA). 2001b. http://www.epa.gov/epaoswer.nonhw/industd/index.htm

U.S. Geological Survey (USGS) 2000. Minerals Yearbook. http://minerals.usgs.gov/minerals/pubs/myb.html 
Wentz, Charles A. 1995. Hazardous Waste Management, 2nd edition (New York, New York: McGraw-Hill, Inc.).

Winslow, G. R., S.X. Liu, and S. Yester. 1998. "Characterizing automotive shredder residue," Automotive Engineering International, 106(9): 78-81.

\section{Chapter 3}

The Aluminum Association (AA). 1998. Life Cycle Inventory Report for the North American Aluminum Industry. Compiled by Roy F. Weston, Inc. August.

American Iron and Steel Institute (AISI). 2001. ULSAC Overview Report. See website http://www.autosteel.org/uslad_overview_report/

Argonne National Laboratory (ANL). 1998. Total Energy Cycle Assessment of Electric and Conventional Vehicles: An Energy and Environmental Analysis. January. pp. 8-42.

Argonne National Laboratory (ANL). 2000. Costs of Lithium-Ion Batteries for Vehicles, ANL/ESD-42. May. p. 7.

Arthur D. Little, Inc. 2000. Cost Analysis of Fuel Cell System for Transportation - Baseline System Cost Estimate. Task 1 and 2 Final Report to: Department of Energy. March.

California Energy Commission. 2001. See Web site: Fuel Cell Vehicles, http://www.energy.ca.gov/education/AFVs/fuelcells.html.

Carlson, Eric. 2001. Personal communications with Mr. Carlson at Arthur D Little, Inc. May 2000 - March 2001.

Curran, Mary Ann. 2001. Personal and email communications with Ms. Curran at the U.S. EPA. January-March.

Das, Sujit. 2000. The Life-Cycle Impacts of Aluminum Body-in-White Automotive Material, pp. 41-44. JOM. August

Dearlove, Thomas. 2000. Advanced Composites Consortium of USCAR. Personal communications. May to November.

DiCicco, John, Jim Kliesch, and Martin Thomas. 2000. ACEEE's Green Book: The Environmental Guide to Cars \& Trucks - Model Year 2001. American Council for an Energy-Efficient Economy. Washington, D.C., p. 23.

Dieselnet, 2001. Emission Standards: USA - Cars and Light-Duty Trucks. See web site: http://www.dieselnet.com/standards/us/light.html. Table 2. 
Ecobilan (Ecobalance) Group. 1999. Data for Environmental Analysis and Management (DEAM) life-cycle inventory database developed by the Ecobilan Group.

Fuel Cells 2000 Web site: Fuel Cells 2000's Benefits of Fuel Cells Page. http://216.51.18.233/fcbenefi.html. (See "Fuel Cell Emissions.")

Gibson, Tom and Ron Williams. 2000. Personal communications with Mr. Gibson and Mr. Williams at General Motors. May to November.

Keoleian, Gregory A., et al. 1997. Industrial Ecology of the Automobile: A Life Cycle Perspecitve. Society of Automotive Engineers, Warrendale, PA, p. 10.

Mascarin, Anthony E., et al. 1995. Costing the Ultralite in Volume Production: Can Advanced Composite Bodies-in-White Be Affordable? The Hypercar Center, Rocky Mountain Institute. Paper written for the 1995 International Body Engineering Conference \& Exposition (Detroit, MI), 31 October - 2 November 1995. Conference Pre-print, August 31.

National Renewables Energy Laboratory (NREL). 2001. See NREL's Center for Transportation Technology and Systems: ADVISOR Glossary. http://www.ctts.nrel.gov/analysis/advisor_doc/glossary.htm. (See “MPGGE.”)

National Research Council (NRC). 2000. Review of the Partnership for a New Generation of Vehicles. Sixth Report. National Academy Press, Washington, D.C. NREL/CP-57028890. Directed Technologies, Inc., 2000. http://205.168.79.27/hydrogen/pdfs/28890mm.pdf, p. 2.

PR Newswire. 2000. General Motors Takes Steps Toward a Fuel Cell-Powered Vehicle for Commercial Use. Today's Newsmaker. November 16.

(S\&T)2 Consultants, Inc. 2000. Assessment of Emissions of Greenhouse Gases from Fuel Cell Vehicles. Prepared for the Methanex Corporation. June 5.

Society of Automotive Engineers (SAE) International. 2000a. Automotive Engineering International. May.

Society of Automotive Engineers (SAE) International. 2000b. Automotive Engineering International. October.

Society of Automotive Engineers (SAE) International. 2001. Automotive Engineering International. March.

Sullivan, John and Jenny Hu. 1995. Life Cycle Energy Analysis for Automobiles. In Proceedings of the 1995 Total Life Cycle Conference. Society of Automotive Engineers. Publication Number P-293. Paper Number 951829. 
Sullivan, John, Carl Johnson, and Jim DeVries. 2000. Personal communications with Mr. Sullivan, Mr. Johnson and Mr. DeVries at Ford Motor Co. May-November.

Sullivan, John. 2000. Ford Motor Company. Personal communication with Mr. Sullivan. August.

Snedeker, Becky, and colleagues. 2001. Email communications with Ms. Snedeker and colleagues at The Aluminum Association, Inc., January.

Thomas, C. E. (Sandy), Brian D. James, and Franklin D. Lomax, Jr. 2000. Analysis of Residential Fuel Cell Systems \& PNGV Fuel Cell Vehicles. Proceedings of the 2000 DOE Hydrogen Program Review NREL/CP-570-28890. Directed Technologies, Inc., 2000. http://205.168.79.27/hydrogen/pdfs/28890mm.pdf, p. 2.

U.S. Department of Commerce (DOC). 2001. See DOC Technology Administration's PNGV web site, http:/www.ta.doc.gov/pngv/introduction/intro.htm

U.S. Environmental Protection Agency (EPA). 2000. Control of Air Pollution From New Motor Vehicles: Tier 2 Motor Vehicle Emissions Standards and Gasoline Sulfur Control Requirements. See web site: http://www.epa.gov/fedrgstr/EPA-AIR/2000/February/Day10/a19a.htm. Table IV.B.-2a.

University of Tennessee Center for Clean Products and Clean Technologies (UT-CCPCT). 1999. Life-Cycle Environmental Evaluation of Aluminum and Composite Intensive Vehicles. Prepared for Oak Ridge National Laboratory. March 5.

University of Tennessee Center for Clean Products and Clean Technologies (UT-CCPCT). 2000. Life-Cycle Design for the Automobile - Environmental Technologies Initiative Project (Draft Report). September 30.

Unnasch, Stefan. 2000. Personal communication with Mr. Unnasch at Arthur D Little, Inc. November 9.

Wang, M. Q. 2000a. From the downloadable Excel version of GREET 1.5a. Center for Transportation Research, Energy System Division, Argonne National Laboratory. ("Vehicles" worksheet).

Wang, M. Q. 2000b. Greet 1.5 - Transportation Fuel-Cycle Model: Methodology, Use, and Results. Center for Transportation Research, Energy System Division, Argonne National Laboratory. ANL/ESD-39, Vol. 2, pp. 8, 35.

Williams, Bob. 2001. Personal communications with Mr. Williams at Scaled Composites, LLC. February-March. 
Wilson, James H. Jr., Maureen A. Mullen, and Erica J. Laich. 2000. Emissions Projections The Long and the Short of It. The Pechan-Avanti Group. See web site http://www.pechan.com/projection99.pdf. p. 4.

Wormald, John. 2000. Market Prospects for Hybrid vehicles. Intertech 2000. Windsor, Ontario. September 11-13. 



\section{APPENDIX A REFERENCES RELATING TO THE CONSTITUENTS OF ASR}

\section{Part 1: References that identify ASR Constituent by Percentage Weight}

Automotive Engineering October, 1992, "Recycling and the Automobile."

Berry, Bryan, February 1992, "Automakers want to recycle all of the car," Iron Age, pp. 2829.

Burlace, C.J., June 1992, "Plastics in Motor Vehicles, Problems and Recycling Opportunities," (Stevenage Hertfordshire, England: Warren Spring Laboratory).

Curlee, Randall T., Sujit Das, Colleen G. Rizy, and Susan M. Schexnayder, 1994. Recent Trends in Automobile Recycling: An Energy and Economic Assessment. ORNL/TM12628, Oak Ridge National Laboratory, Oak Ridge, TN, March.

Fisher, Michael M., and Frank E. Mark, March 1999, "The Role of Plastics in Automotive Shredder Residue (ASR): Characterization and Environmental Assessment," (Warrendale, PA: SAE (Society of Automotive Engineers) International, Technical Paper Series, 199901-0664).

Kincaid, Lori E., et al., July 1996, "Vehicle Recycling and Disposal Policies in Industrialized and Developing Countries," (Knoxville, TN: University of Tennessee Center for Clean Products and Clean Technologies). Report prepared for American Automobile Manufacturers Association.

Lanoir, D., et al., 1997, "Physical \& Chemical Characterization of Automotive Shredder Residues,” Waste Management \& Research: 15(3), pp. 267-276.

\section{Part 2: References for ASR Without Composition by Weight/Percentages}

Brooke, Lindsay, Gerry Kobe, and Christopher A. Sawyer, September 1990, "Recyclability: The materials and designs you choose today will impact America's solid waste stream tomorrow," Automotive Industries, 170, pp. 40-50.

Kiser, Kent, November/December 1991, "Solving the Fluff Dilemma" Scrap Processing and Recycling, pp. 115-120.

Klempner, Daniel, Kurt C. Frisch, B. Pokorski and Vahid Sendijarevic, March 1999, "Characterization of Various ASR Streams" (Warrendale, PA: SAE International, Technical Paper Series 1999-01-0670).

Mark, Frank E. and Michael M. Fisher, March 1999, "Environmentally Sound Energy Recovery from Automotive Shredder Residue: European Overview of Co-Combustion 
Using Modern Mass Burn Facilities" (Warrendale, PA: SAE International, Technical Paper Series 1999-01-0990).

Mark, Frank E., Michael M. Fisher, and Kenneth A. Smith, March 1998, "Energy recovery from automotive shredder residue through co-combustion with municipal solid waste," (van Nieuwenhuyse, Brussels: Association of Plastics Manufacturers in Europe, Technical Paper Series).

Radimsky, Jan and Gin Watson, June 1989, "Treatment Levels for Auto Shredder Waste," (Sacramento, CA: State of California, Department of Health Services, Toxic Substances Control Division, Alternative Technology Section, Technical Support Document).

U.S. Environmental Protection Agency, April 1991, PCB, Lead, and Cadmium Levels in Shredder Waste Materials: A Pilot Study (Washington, DC: EPA, Office of Toxic Substances and Office of Solid Waste, EPA 560/5-90-008A).

Winslow, G. R., S.X. Liu, and S. Yester, September 1998, “Characterizing automotive shredder residue,” Automotive Engineering International, 106(9), pp. 78-81. 


\section{APPENDIX B \\ GLOSSARY OF ACRONYMS AND TECHNICAL TERMS USED IN THE LCA}

$3 \mathrm{XV}$

Ancillary

ANL

AP

ASR

BIW

BOD

$\mathrm{BOF}$

BTU

BUWAL

CCPCT

$\mathrm{CF}$

CFC

CFC11

CFC11-eq.

CFRP

$\mathrm{CH}_{4}$

CHEMS

$\mathrm{CO}$

$\mathrm{CO}_{2}$

$\mathrm{CO}_{2}$-eq.

Cradle-to-gate

Cradle-to-grave

CTG

DEAM

DEC

DOE

Downstream

E\&MP

EAF

EC
New generation vehicle, three times more fuel efficient (based on miles per gallon) than the 1994 baseline vehicle (a Taurus-class, 4-door mid-sized sedan)

With regard to materials inputted into a process, ancillary materials are those materials that do not become part of the product, but are needed to make the process work (see also primary).

Argonne National Laboratory

Acidification Potential

Automobile Shredder Residue

Body-in-White

Biochemical Oxygen Demand

Basic Oxygen Furnace

British Thermal Unit

Bundesamt für Umwelt, Wald und Landschaft (German name for the Swiss Agency FOEFL)

Center for Clean Products and Clean Technologies

Carbon Fiber

Chlorofluorocarbon

Chlorofluorocarbon11 (also "trichlorofluoromethane")

Chlorofluorocarbon 11 equivalent

Carbon Fiber-Reinforced Polymer

Methane

Chemical Hazard Evaluation and Management System

Carbon Monoxide

Carbon Dioxide

$\mathrm{CO}_{2}$ equivalents

A term that refers to the combination of the Extraction, Materials

Processing, and Manufacturing life-cycle stages.

A term that refers to the combination of all life-cycle stages.

Cradle-to-gate

Data for Environmental Analysis and Management

Diethylene Chloride

Department of Energy

Sometimes used to refer specifically to the End-of-Life life-cycle stage.

Also is a referencing term that refers to the life-cycle stages that occur after the life-cycle stage of interest. If reviewing Manufacturing stage information, downstream would refer to the Use and EOL life-cycle stages (see also upstream).

Extraction and Materials Processing

Electric Arc Furnace

Ethylene Chloride 
Environmental A term used in LCA that typically refers to the cradle-to-grave

Profile

EOL

EPA

ETH

FCV

FOEFL

$\mathrm{ft}^{3}$

Functional unit

$\mathrm{H} 2 \mathrm{FCV}$

$\mathrm{HEV}$

GFRP

GREET

GWP

$\mathrm{kg}$

ICE

ICEV

Impact score

IS

lbs

LCA

LCD

LCI

LCIA

LiIon

LT

$\mathrm{m}^{3}$

MEA

$\mathrm{MeOH}$

MMBTU

mpg

mpgge

NFMS

$\mathrm{NiMH}$

NMHC

NMOG

NMP inventory or impacts for a particular product as relates to the product's functional and service units.

End-of-Life

Environmental Protection Agency

Eidgenössische Technische Hochschule Zürich (Swiss for the "Swiss

Federal Institute of Technology Zurich")

Fuel Cell Vehicle

Federal Office of Environment, Forests and Landscape (Swiss)

Cubic Feet

Typically in LCA, the quantity (e.g., number of paper cup[s]) or mass

(mass of the paper cup[s]) of a product traversing the entire life-cycle (applies to all life-cycle stages - cradle-to-grave). This value is used as a starting point from which to develop the LCI for an environmental profile.

Direct Hydrogen Fuel Cell Vehicle

Hybrid Electric Vehicle

Glass Fiber-Reinforced Polymer

Greenhouse gases, Regulated Emissions, and Energy use in

Transportation

Global Warming Potential

Kilogram

Internal Combustion Engine

Internal Combustion Engine Vehicle

LCA impact results are expressed as impact scores in various units of measurement, depending on the impact category.

Impact Score

Pounds

Life-Cycle Assessment

Life-Cycle Design

Life-Cycle Inventory

Life-Cycle Impact Assessment

Lithium Ion

Long-term

Cubic Meters

Membrane Electrode Assembly

Methanol

One million BTU

Miles per Gallon

Miles per Gallon Gasoline Equivalent

Nonferrous Metal Separation

Nickel Metal Hydride

Non Methane Hydrocarbon

Non Methane Organic Gas

$\mathrm{N}$-methylpyrrolidone 


\begin{tabular}{|c|c|}
\hline $\mathrm{NO}_{2}$ & Nitrogen Dioxide \\
\hline NOx & Nitrogen Oxides \\
\hline OAAT & Office of Advanced Automotive Technologies \\
\hline ORNL & Oak Ridge National Laboratory \\
\hline ODP & Ozone Depletion Potential \\
\hline OTV & Odor Threshold Value \\
\hline $\mathrm{PbA}$ & Lead-Acid \\
\hline PEM & Proton Exchange Membrane \\
\hline PET & Polyethylene Terephthalate \\
\hline Phosphate-eq. & Phosphate equivalents \\
\hline PGM & Platinum Group Metal \\
\hline PM & Particulate Matter \\
\hline PNGV & Partnership for a New Generation of Vehicles \\
\hline POCP & Photochemical Oxidant Creation Potential \\
\hline Primary & $\begin{array}{l}\text { With regard to material inputs to a process, primary materials are those that } \\
\text { become part of the product (see also ancillary). }\end{array}$ \\
\hline & $\begin{array}{l}\text { With regard to data in general, primary data refers to first-hand data that } \\
\text { typically came from a specific company or manufacturing facility (see also } \\
\text { secondary). }\end{array}$ \\
\hline Profile & See Environmental profile \\
\hline PVC & Polyvinyl Chloride \\
\hline PVDF & Polyvinylidene Fluoride \\
\hline PWB & Printed Wiring Board \\
\hline RCRA & Resource Conservation and Recovery Act \\
\hline RFCV & Reformed Fuel Cell Vehicle \\
\hline Score & See Impact score \\
\hline Secondary & $\begin{array}{l}\text { With regard to data in general, refers to data that came from a nonspecific, } \\
\text { generic source (e.g., LCA databases; see also primary). }\end{array}$ \\
\hline Service unit & $\begin{array}{l}\text { Typically in LCA, the value chosen to represent the lifespan of a product. } \\
\text { For cars this may be miles, for a toaster it may be pieces of toast toasted. } \\
\text { This value works in concert with the product's functional unit to build a } \\
\text { product's environmental profile (starting with the LCI) to define how that } \\
\text { product is used during the Use life-cycle stage (applies only to the Use life- } \\
\text { cycle stage). }\end{array}$ \\
\hline SLI & Starting Lighting Ignition \\
\hline $\mathrm{SO}_{2}$ & Sulfur Dioxide \\
\hline $\mathrm{SO}_{2}$-eq. & $\mathrm{SO}_{2}$ equivalents \\
\hline $\mathrm{SOx}$ & Sulfur Oxides \\
\hline SULEV & Super Ultra Low Emission Vehicle \\
\hline TEAM & Tool for Environmental Analysis and Management \\
\hline TSS & Total Suspended Solids \\
\hline ULSAB & UltraLight Steel Auto Body \\
\hline ULSAC & UltraLight Steel Auto Closures \\
\hline
\end{tabular}


Upstream Sometimes used to refer specifically to the Extraction and Materials Processing life-cycle stages. Also is a referencing term that refers to the life-cycle stages that occur before the life-cycle stage of interest. If reviewing Use stage information, upstream would refer to the cradle-togate life-cycle stages (see also downstream).

VOC Volatile Organic Compound 


\section{APPENDIX C IMPACT CATEGORY DEFINITIONS}

In this appendix is presented a brief description of each impact category included in this assessment.

Nonrenewable Resource Use/Depletion - This refers to the extraction of nonrenewable (stock) resources such as fossil fuels, wood or minerals. Depletion of materials results from the extraction of nonrenewable resources. Nonrenewable resource impact scores are based on the amount of primary, ancillary, and fuel inputs of nonrenewable materials, and are calculated in units of mass.

Renewable Resource Use - This refers to the use of renewable (flow) resources such as water or biological resources (i.e., forest products, other plants or animals). Depletion of materials, which results from the extraction of renewable resources faster than they are renewed, may occur but is not specifically modeled or identified in the renewable resource impact score. Renewable resource impact scores are based on process inputs in the LCI: primary, ancillary, water, and fuel inputs of renewable materials. The scores are calculated in units of mass.

Energy Use - General energy consumption is used as an indicator of potential environmental impacts from the entire energy generation cycle. Energy use impact scores are based on fuel and electricity inputs. Impact scores are based on the overall inventory amount of energy use, converted to common units of BTU or MJ.

Global Warming Potential - The buildup of $\mathrm{CO}_{2}$ and other greenhouse gases in the atmosphere may generate a "greenhouse effect" of rising temperature and climate change. Global warming potential (GWP) refers to the release of $\mathrm{CO}_{2}$ and other chemicals that may contribute to this effect. The impact scores for global warming (global climate change) effects are calculated using the mass of a global warming gas released to air modified by a GWP equivalency factor. The GWP equivalency factor is an estimate of a chemical's atmospheric lifetime and radiative forcing that may contribute to global climate change compared to the reference chemical $\mathrm{CO}_{2}$. Therefore, GWPs are in units of $1 \mathrm{bs}-\mathrm{CO}_{2}$ equivalents. GWPs have been published for known global warming chemicals within differing time horizons. The 100year time horizon is the chosen time horizon for the "CHEMS, plus" methodology. Although LCA does not have a temporal component of the inventory, these impacts are expected to be far enough into the future that releases occurring throughout the life cycle of a product would be within the 100-year time frame.

Stratospheric Ozone Depletion - The stratospheric ozone layer filters out harmful ultraviolet radiation from the sun. Chemicals such a chlorofluorocarbons, if released to the atmosphere, may result in ozone-destroying chemical reactions. Stratospheric ozone depletion refers to the release of chemicals that may contribute to this effect. Impact scores will be based on the identity and amount of ozone depleting chemicals released to air. Currently identified ozone depleting chemicals are those with ozone depletion potentials (ODPs), which measure the change in the ozone column in the equilibrium state of a substance compared to the reference chemical chlorofluorocarbon (CFC)-11. Thus, ODPs are in units of lbs-CFC11 equivalents. 
Acidification - This refers to the release of chemicals that may contribute to the formation of acid precipitation. Impact score calculation is based on the amount of chemical released to air that would cause acidification and the acidification potentials (APs) equivalency factor for that chemical. The AP equivalency factor is the number of hydrogen ions that can theoretically be formed per mass unit of the pollutant being released compared to sulfur dioxide $\left(\mathrm{SO}_{2}\right)$. Therefore, the APs are in units of $1 \mathrm{bs}-\mathrm{SO}_{2}$ equivalents.

Photochemical Smog Formation - Photochemical oxidants are produced in the atmosphere from sunlight reacting with hydrocarbons and nitrogen oxides. At higher concentrations they may cause or aggravate health problems, plant toxicity, and deterioration of certain materials. Photochemical oxidant creation potential (POCP) refers to the release of chemicals that may contribute to this effect. The POCP is based on simulated trajectories of tropospheric ozone production with and without volatile organic compounds (VOCs) present. The POCP is a measure of a specific chemical compared to the reference chemical ethylene, thus the POCP is in units of lbs-ethylene equivalents. Impact scores are based on the identity and amount of chemicals with POCP equivalency factors released to the air and the chemical-specific equivalency factor.

$\underline{\text { Particulates }}$ - This refers to the release and build-up of particulate matter primarily from combustion processes. Impact scores are based on the mass of particulate release amounts to the air.

Odor (aesthetics) - This refers to impacts that detract from the quality of the local environment from a human perspective. Impact scores are based on the identity and amount of odor-causing chemicals released to the air and their odor threshold value (OTV). The OTV is a concentration which, when divided into the mass output of a chemical results in an impact score in units of volume of malodorous air.

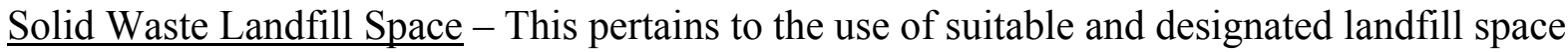
as a natural resource and includes municipal waste or construction debris landfill space. A solid waste landfill impact score is calculated using solid waste outputs disposed of in a solid waste (nonhazardous) landfill. Impact score calculation is based on the volume of solid waste, and waste densities are used to convert from mass-based to volume-based values.

Hazardous Waste Landfill Space - This pertains to the use of suitable and designated landfill space as a natural resource and includes hazardous waste as designated and regulated under the Resource Conservation and Recovery Act (RCRA). Impact score calculation is based on the volume of hazardous waste, and waste densities are used to convert from mass-based to volume-based values.

Eutrophication - Eutrophication (nutrient enrichment) impacts to water are based on the identity and concentrations of eutrophication chemicals either directly released to surface water or released to surface water after treatment. Equivalency factors for eutrophication have been developed assuming nitrogen $(\mathrm{N})$ and phosphorus $(\mathrm{P})$ are the two major limiting nutrients of importance to eutrophication. Therefore, the partial equivalencies are based on the 
ratio of $\mathrm{N}$ to $\mathrm{P}$ in the average composition of algae $\left(\mathrm{C}_{106} \mathrm{H}_{263} \mathrm{O}_{110} \mathrm{~N}_{16} \mathrm{P}\right)$ compared to the reference compound phosphate $\left(\mathrm{PO}_{4}{ }^{3-}\right)$. Thus, the factors are in units of lbs-phosphate equivalents.

Water quality - BOD - This is based on the identity and quantity (mass) of biological oxygen demand (BOD) as a wastewater/water quality parameter as released to a surface water.

Water quality - TSS - This is based on the identity and quantity (mass) of total suspend solids (TSS) as a wastewater/water quality parameter as released to a surface water. 



\section{APPENDIX D \\ A CLOSER LOOK AT THE DATA - PARTICULARS AND ENERGY INTENSITY DATA}

In this appendix, we present information on the data itself, in an effort to highlight the dependence on data quality in LCAs.

\begin{tabular}{|c|c|c|c|c|c|c|c|}
\hline \multicolumn{8}{|c|}{ Table D.1. Information on the Data Used in the Assessments } \\
\hline \multicolumn{8}{|l|}{ Column Information Key: } \\
\hline \multicolumn{8}{|c|}{ a - Were notes of any kind provided with the data? ['y' - yes; '-' - no] } \\
\hline \multicolumn{8}{|c|}{ b - Need an electric grid to complete inventory? ['y' - yes; '-' - no] } \\
\hline \multicolumn{8}{|c|}{$\begin{array}{l}\text { c - Radioactive releases included in the inventory? ['y' - yes, many individual entries included; } \\
\text { '2' - only unspeciated categories for each media (air + water) included ; '-' - no] }\end{array}$} \\
\hline \multicolumn{8}{|c|}{ d - Transportation included in the inventory? ['y' - yes; '-' - nothing stated about transport] } \\
\hline \multicolumn{8}{|c|}{$\begin{array}{l}\text { e - Solid waste information presentation: 'a' - as expected (e.g., haz. waste, slags); 'u' - "ultimate } \\
\text { fate characterization" (e.g., carbon, cadmium and nitrogen as solid wastes); '-' - none included }\end{array}$} \\
\hline DEAM Data & Source & Date & $\mathbf{a}$ & $\mathbf{b}$ & c & d & $\mathbf{e}$ \\
\hline ABS Prod. & Boustead & 97 & $\mathrm{y}$ & 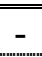 & - & - & $\overline{\mathrm{a}}$ \\
\hline Acrylonitrile Prod. & Boustead & 97 & $\mathrm{y}$ & - & - & - & $\mathrm{a}$ \\
\hline Alum. ingot - $100 \%$ virgin & Energetics-DOE & 97 & $\mathrm{y}$ & - & 2 & - & $\mathrm{a}$ \\
\hline Alum. ingot $-100 \%$ recycled & Energetics-DOE & 97 & $\mathrm{y}$ & - & 2 & - & $\mathrm{a}$ \\
\hline Aluminum Oxide Prod. & FOEFL, BUWAL & 91 & $\mathrm{y}$ & $\mathrm{y}$ & - & - & $\mathrm{a}$ \\
\hline Automotive Wrought Aluminum & Energetics-DOE & 97 & $\mathrm{y}$ & - & 2 & - & $\mathrm{a}$ \\
\hline Carbon Black Prod. & ETH, Chimie Industrielle & $93-96$ & $\mathrm{y}$ & $\mathrm{y}$ & $\mathrm{y}$ & - & $\mathrm{u}$ \\
\hline Carbon Dioxide Prod. & Procédés de pétrochimie & 85 & $\mathrm{y}$ & $\mathrm{y}$ & - & - & $\mathrm{u}$ \\
\hline Cobalt Prod. & IDEMAT & 95 & $\mathrm{y}$ & - & - & - & $\mathrm{a}$ \\
\hline Epoxy Resin Prod. (liquid) & Boustead & 97 & $\mathrm{y}$ & - & - & - & $\mathrm{a}$ \\
\hline Ethylene Glycol Prod. & Procédés de pétrochimie & 85 & $\mathrm{y}$ & $\mathrm{y}$ & - & - & $\mathrm{a}$ \\
\hline Ethylene Oxide Prod. & Procédés de pétrochimie & 85 & $\mathrm{y}$ & $y$ & - & - & $\mathrm{a}$ \\
\hline Fuel Oil \#2 & Seven sources cited & $83-93$ & $\mathrm{y}$ & - & 2 & $\mathrm{y}$ & $\mathrm{a}$ \\
\hline Glass Bottle Prod. (colorless) & BUWAL 250 & $94-98$ & $\mathrm{y}$ & - & - & - & $\mathrm{a}$ \\
\hline Graphite Prod. & None Provided & $<---$ & $\mathrm{y}$ & $\mathrm{y}$ & - & - & - \\
\hline Hydrogen Prod.-from NG cracking & None Provided & $<---$ & $\mathrm{y}$ & $\mathrm{y}$ & - & - & $\mathrm{a}$ \\
\hline Iron Ore Mining & FOEFL, BUWAL & $75-80$ & $\mathrm{y}$ & - & 2 & - & $\mathrm{a}$ \\
\hline Magnesium Prod. & IDEMAT & 95 & $\mathrm{y}$ & - & - & - & - \\
\hline Methanol Prod. & Four sources cited & $91-94$ & $\mathrm{y}$ & - & - & - & $\mathrm{a}$ \\
\hline Nickel Prod. & ETH CD-ROM & 91 & $\mathrm{y}$ & - & - & $\mathrm{y}$ & $\mathrm{u}$ \\
\hline PET Resin Prod. & Boustead & 98 & $\mathrm{y}$ & - & - & - & $\mathrm{a}$ \\
\hline Platinum Prod. & ETH CD-ROM & 96 & $\mathrm{y}$ & - & - & $\mathrm{y}$ & $\mathrm{u}$ \\
\hline Polyethylene Prod. (all grades) & PWMI & 93 & $\mathrm{y}$ & - & - & - & $\mathrm{a}$ \\
\hline Potassium Hydroxide Prod. & FOEFL, BUWAL & 91 & $\mathrm{y}$ & $\mathrm{y}$ & $\mathrm{y}$ & - & $\mathrm{u}$ \\
\hline PVC Prod. & Boustead & 97 & $\mathrm{y}$ & - & - & - & $\mathrm{a}$ \\
\hline Steel Prod., hot-rolled (BOF) & FOEFL, BUWAL, other & $75-90$ & $\mathrm{y}$ & - & 2 & - & $\mathrm{a}$ \\
\hline Sulfuric Acid Prod. & Fertilizer Inst,; EPA & $94 ; 98$ & $\mathrm{y}$ & - & 2 & - & $\mathrm{a}$ \\
\hline Titanium Prod. & IDEMAT & 95 & $\mathrm{y}$ & - & - & $\mathrm{y}$ & $\mathrm{a}$ \\
\hline Vanadium Prod. & IDEMAT & 95 & $\mathrm{y}$ & - & - & $\mathrm{y}$ & $\mathrm{a}$ \\
\hline Vinyl Acetate Prod. & BUWAL n²32 & 94 & $\mathrm{y}$ & $\mathrm{y}$ & $\mathrm{y}$ & - & $\mathrm{u}$ \\
\hline Zinc Prod. & ETH CD-ROM & 96 & $\mathrm{y}$ & - & - & $\mathrm{y}$ & $\mathrm{u}$ \\
\hline
\end{tabular}


In Table D.1, some of the data utilized in these assessments are listed along side information on their source, applicable date and other specifics. The pecifics are individual pieces of information about each dataset that further characterize that dataset through comparison to all datasets. Note that all of the secondary data used in these assessments came from Ecobalance's "DEAM” database.

As can be seen just from the data shown (which span all three assessments), there is significant source and temporal variations in the data. These variations create reduced consistency and thus quality in the assessments where the data is used. Additionally, Table D.1 shows that some datasets include certain data specifics while others leave that information out (see the provided key for a description of the abbreviations used).

In LCA, consistency is sought in data used in assessments to improve data quality. As LCA practitioners, international governments, non-profit organizations and environmental defense groups work toward bringing greater consistency to LCA data, the value of LCA as a tool for environmental evaluation will improve. There are currently efforts on-going worldwide to "homogenize" life-cycle inventory data so that some consistency can be expected by lifecycle practitioners, and so that the quality of assessments that use that data can be improved. Efforts include those such as the U.S. EPA's Electricity Database Workshop organized to work toward establishing more consistent electricity data in LCIs (Curran 2001).

Other data information presented here is a listing of the energy intensities of materials used in these analyses. Table D.2 reveals the energy intensity (EI) values for most of the materials used in these assessments. The "Total EI" values were calculated by dividing the supplied "total primary energy" by the amount of product being produced in each dataset (which varied from less than $1 \mathrm{~kg}$ to $1,000 \mathrm{~kg}$ ). "Total supplied energy" refers to the total, cumulative energy inputted into a material's extraction and processing up to the point of the final material (for example, hot-rolled BOF steel or aluminum ingot). This value includes the fuel and feedstock values. By including the feedstock energy, the value increases the fossil fuel-based materials' (petroleum, coal and natural gas) energy intensity; the non-fossil fuel-based materials' energy intensities are not changed, as little to no feedstock energy is associated with these materials. The "Fuel EI" values show the energy intensity value created by dividing only the fuel portion of the total supplied energy by the amount of product produced.

It is expected that the platinum group metals (PGMs - platinum, palladium, rhodium, ruthenium, iridium and osmium) would be at the top of such a list as these precious metals require extraordinary amounts of extraction and refining to produce quality materials in the ounce range. 


\begin{tabular}{|c|c|c|}
\hline \multicolumn{3}{|c|}{ Table D.2. Energy Intensity Data } \\
\hline \multirow[b]{2}{*}{ DEAM Data (Process) } & \multicolumn{2}{|c|}{ 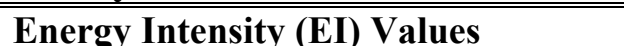 } \\
\hline & Fuel EI (MJ/kg) & Total EI (MJ/kg) \\
\hline Rhodium Prod. & 362,295 & 362,295 \\
\hline Platinum Prod. & 185,697 & 185,697 \\
\hline Silver Prod. & 1,223 & 1,223 \\
\hline Titanium Prod. & 566 & 566 \\
\hline Vanadium Prod. & 415 & 415 \\
\hline Tungsten Prod. & 329 & 329 \\
\hline Magnesium Prod. & 269 & 294 \\
\hline Nickel Prod. & 251 & 255 \\
\hline Chromium Prod. & 222 & 233 \\
\hline Alum. ingot $-100 \%$ virgin & 213 & 241 \\
\hline Tin Prod. & 204 & 206 \\
\hline Automotive Wrought Aluminum & 191 & 215 \\
\hline Cobalt Prod. & 130 & 130 \\
\hline EPDM Prod. & 92 & 151 \\
\hline Epoxy Resin Prod. (liquid) & 91 & 130 \\
\hline Polyamide 6,6 (Nylon 6,6) & 88 & 133 \\
\hline Ferrite Mfg. - EB & 84 & 93 \\
\hline PMMA Sheet Prod. & 84 & 121 \\
\hline Copper Ingot Prod. & 74 & 74 \\
\hline Polycarbonate Prod. (PC) & 71 & 106 \\
\hline Manganese Prod. & 70 & 70 \\
\hline Polyurethane Foam Prod., Flexible & 64 & 96 \\
\hline Zinc Prod. & 58 & 59 \\
\hline Methanol Prod. & 52 & 80 \\
\hline Ethylene Glycol Prod. & 45 & 74 \\
\hline Paper Prod., Bleached & 44 & 60 \\
\hline Acrylonitrile Prod. & 38 & 79 \\
\hline Acetone Prod. & 37 & 75 \\
\hline PET Resin Prod. & 36 & 73 \\
\hline ABS Prod. & 34 & 76 \\
\hline Polystyrene, high impact (HIPS) & 34 & 77 \\
\hline PVC Prod. & 32 & 61 \\
\hline HDPE Prod. & 31 & 75 \\
\hline Polypropylene Prod. (PP) & 30 & 75 \\
\hline Polyester Resin Prod. - EB & 26 & 49 \\
\hline Lead Prod. (50\% recycled) & 19 & 20 \\
\hline PE Prod. (all grades) & 18 & 79 \\
\hline Vinyl Acetate Prod. & 17 & 47 \\
\hline Aluminum Oxide Prod. & 13 & 13 \\
\hline Steel Prod., hot-rolled (EAF) & 13 & 14 \\
\hline Steel Prod., hot-rolled (BOF) & 13 & 27 \\
\hline Gasoline Prod. & 12 & 58 \\
\hline Natural Gas Prod. & 11 & 64 \\
\hline Alum. ingot $-100 \%$ recycled & 10 & 10 \\
\hline
\end{tabular}




\section{Table D.2. Energy Intensity Data (continued)}

\begin{tabular}{|l|r|r|}
\hline \multicolumn{3}{|c|}{ Table D.2. Energy Intensity Data (continued) } \\
\hline \hline & \multicolumn{2}{|l|}{ Energy Intensity (EI) Values } \\
\cline { 2 - 3 } DEAM Data (Process) & \multicolumn{1}{|c|}{ Fuel EI (MJ/kg) } & Total EI (MJ/kg) \\
\hline \hline Potassium Hydroxide Prod. & 8 & 8 \\
\hline LPG Prod. & 8 & 52 \\
\hline Lubricant Prod. & 8 & 52 \\
\hline Diesel Fuel Prod. & 7 & 52 \\
\hline Fuel Oil \#2 & 7 & 52 \\
\hline Glass Bottle Prod. (colorless) & 7 & 7 \\
\hline Carbon Black Prod. & 7 & 92 \\
\hline Ethylene Oxide Prod. & 6 & 45 \\
\hline Fuel Oil \#6 & 5 & 48 \\
\hline Petroleum Coke Prod. & 5 & 48 \\
\hline Carbon Dioxide Prod. & 2 & 28 \\
\hline Sulfuric Acid Prod. & -1 & 16 \\
\hline
\end{tabular}




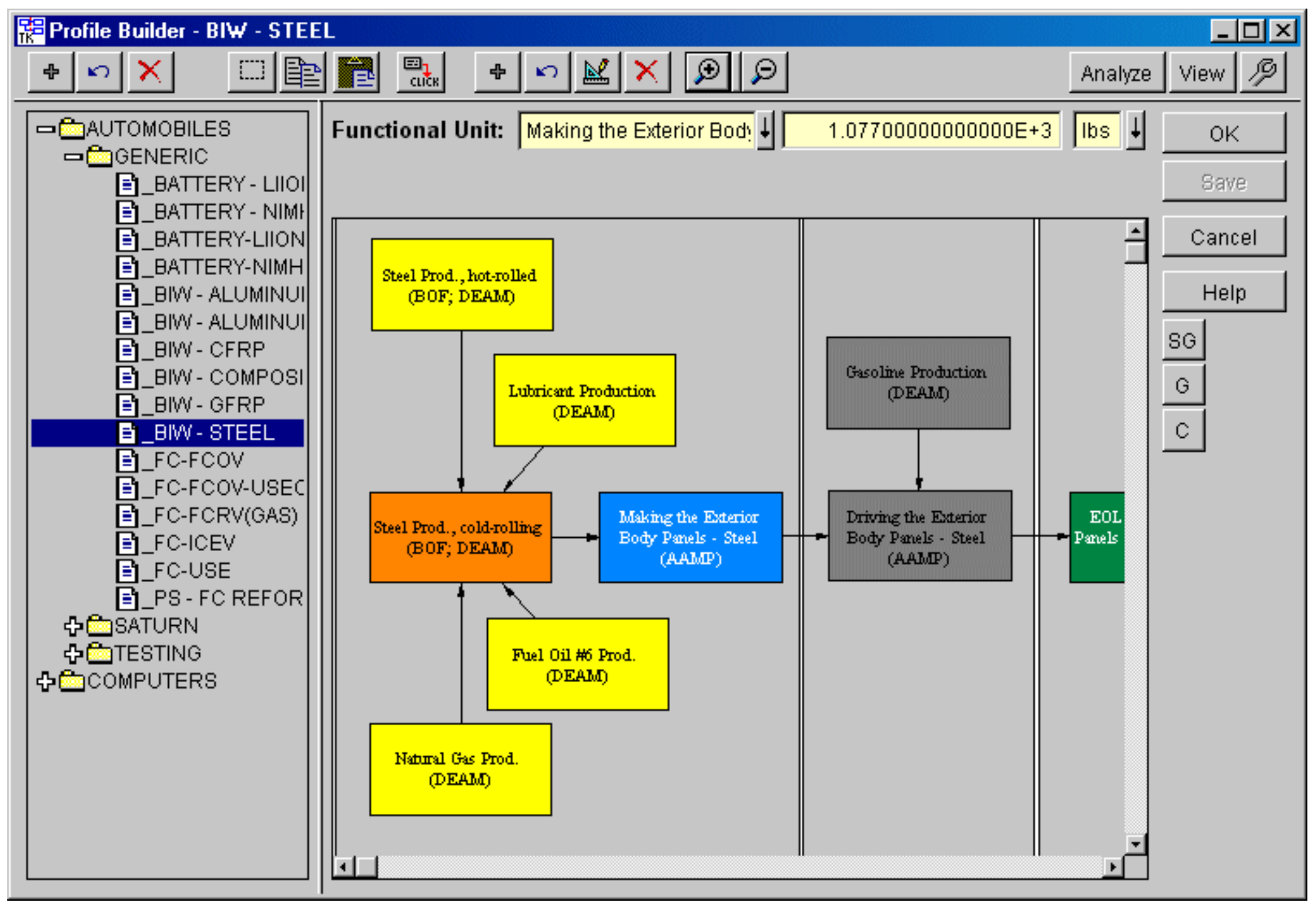




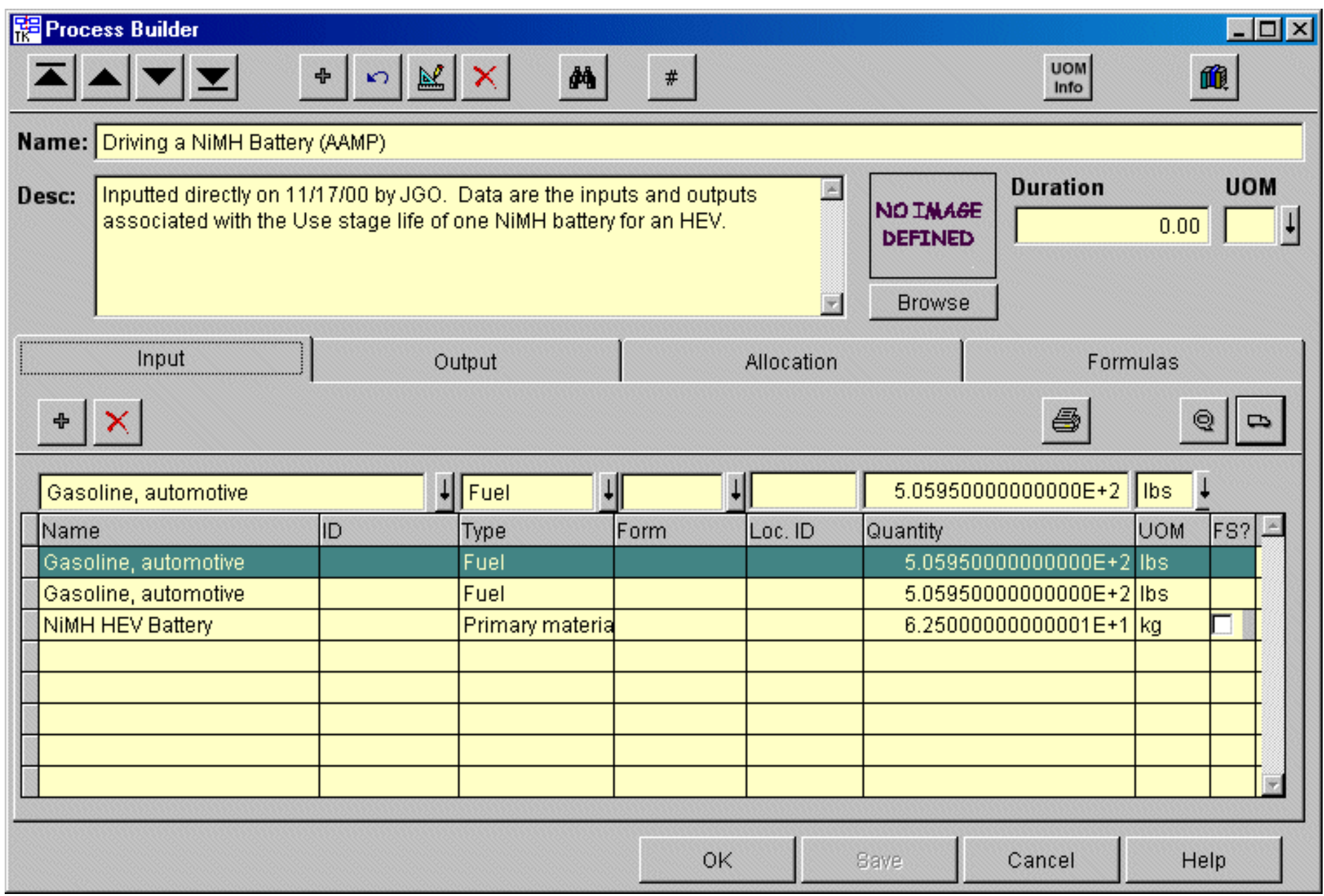

Figure E.2. The LCD Toolkit's Process Builder - Manages the Building of Processes from Individual Inputs and Outputs 


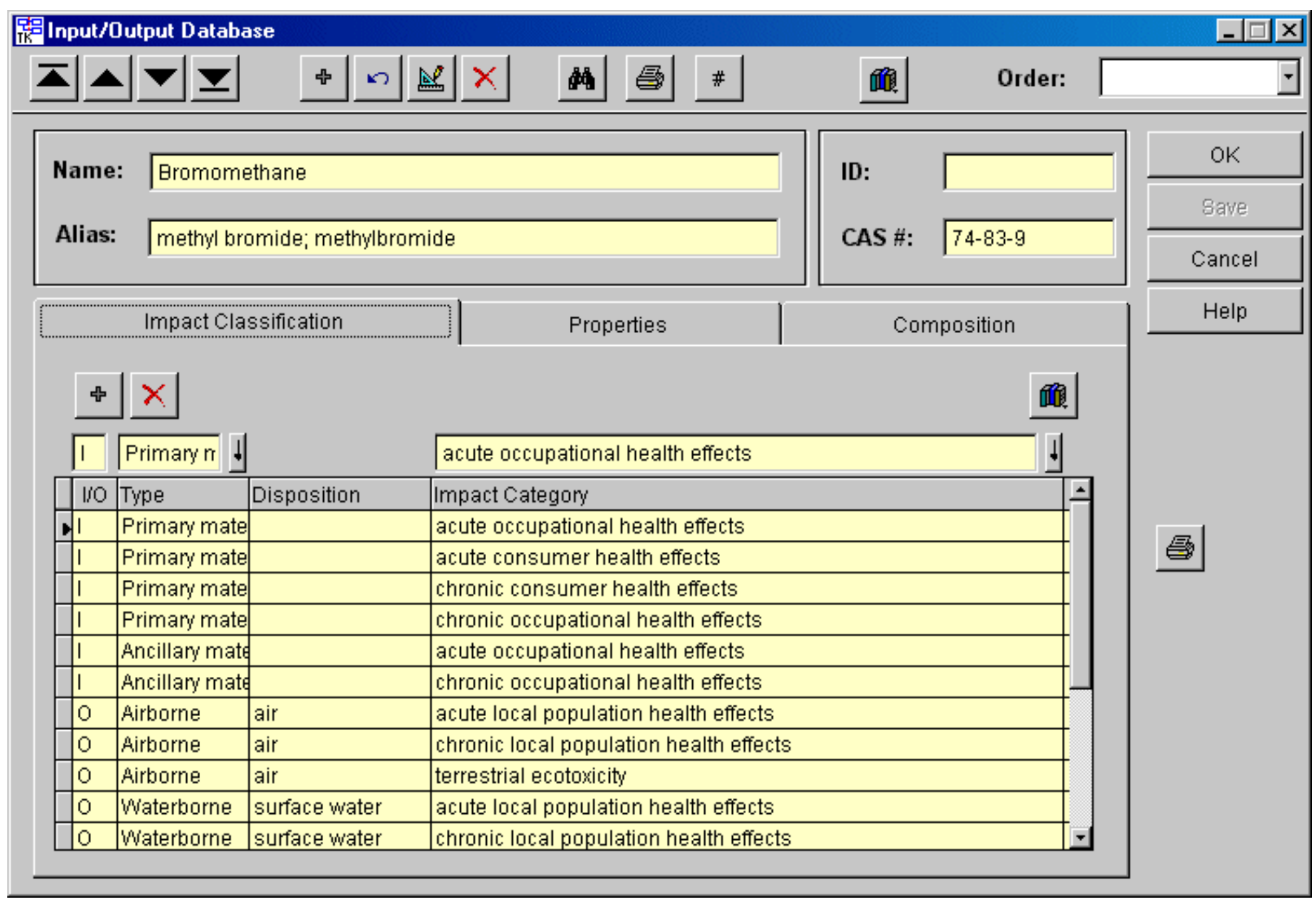

Figure E.3. The LCD Toolkit's Input/Output Database - Manages all the Inputs and Outputs used to build Processes 